\title{
\#USGS
}

science for a changing world

Prepared in cooperation with the Federal Higliway Aduthistration $0 \%$

\section{Trends of Abutment-Scour Prediction Equations Applied to 144 Field Sites in South Carolina}

Open-File Report 2003-295

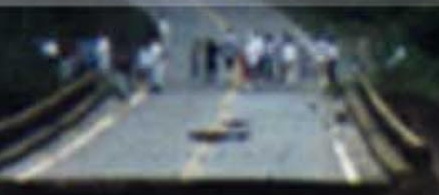




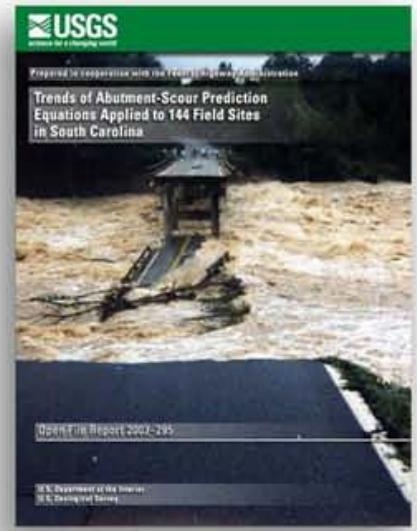

COVER PHOTOGRAPH: Bridge over the Enoree River at S.C. Highway 418 collapsed on August 27, 1995, due to flooding caused by rainfall from Tropical Depression Jerry.

Photograph by J. Michael Hall, U.S. Geological Survey 


\section{Trends of Abutment-Scour Prediction Equations Applied to 144 Field Sites in South Carolina}

By Stephen T. Benedict, Nikhil Deshpande, Nadim M. Aziz, and Paul A. Conrads

Prepared in cooperation with the Federal Highway Administration

Open-File Report 2003-295 


\section{U.S. Department of the Interior \\ Dirk A. Kempthorne, Secretary}

\section{U.S. Geological Survey \\ Mark D. Myers, Director}

\section{U.S. Geological Survey, Reston, Virginia: 2006}

For product and ordering information:

World Wide Web: http://www.usgs.gov/pubprod

Telephone: 1-888-ASK-USGS

For more information on the USGS - the Federal source for science about the Earth, its natural and living resources, natural hazards, and the environment:

World Wide Web: http://www.usgs.gov

Telephone: 1-888-ASK-USGS

Any use of trade, product, or firm names is for descriptive purposes only and does not imply endorsement by the U.S. Government.

Although this report is in the public domain, permission must be secured from the individual copyright owners to reproduce any copyrighted materials contained within this report.

Suggested citation:

Benedict, S.T., Deshpande, Nikhil, Aziz, N.M., and Conrads, P.A., 2006, Trends of abutment-scour prediction equations applied to 144 field sites in South Carolina: U.S. Geological Survey Open-File Report 2003-295, 150 p., available online at http://pubs.water usgs.gov/ofro3-295/. 


\section{Contents}

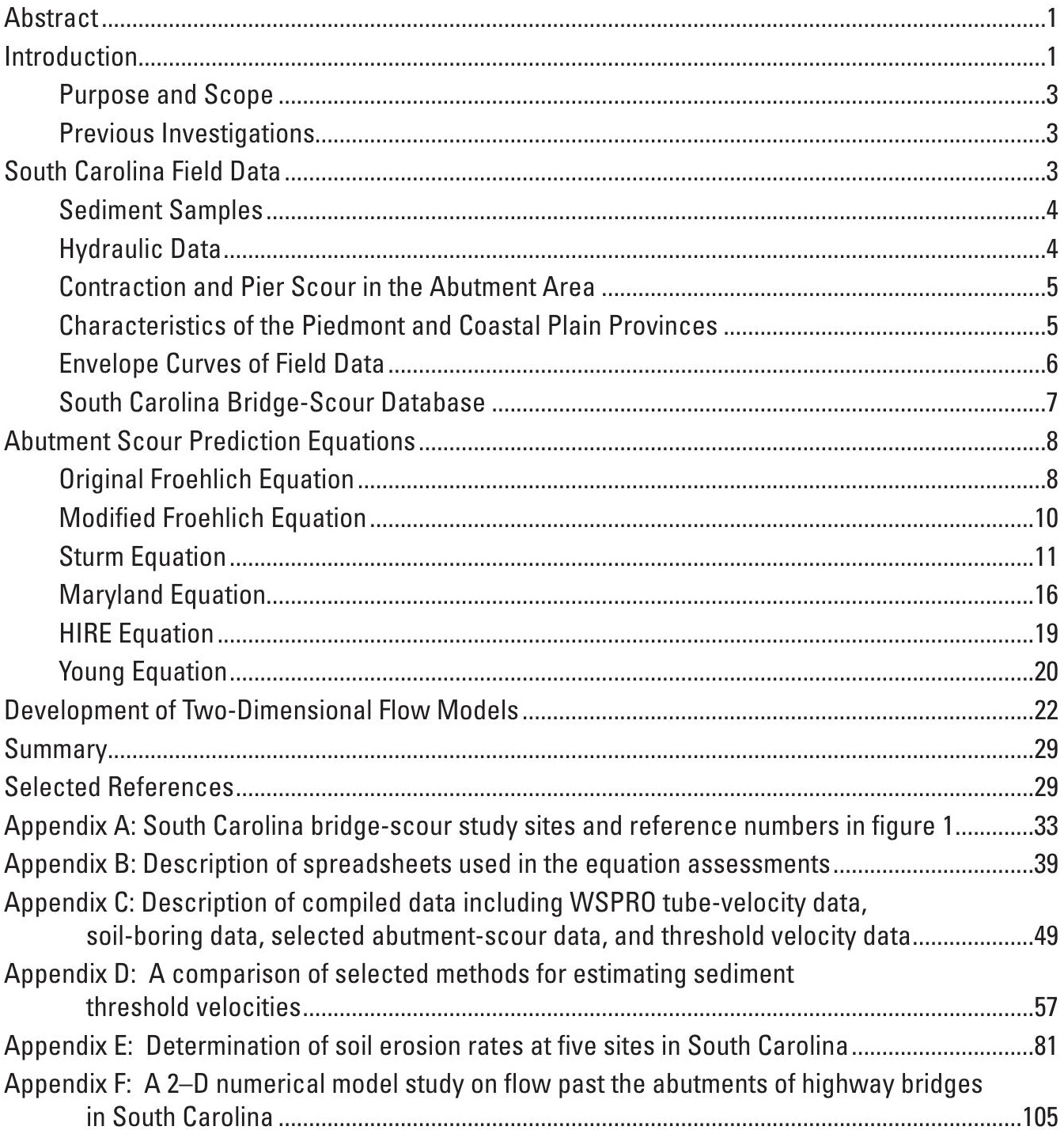

\section{Figures}

1. Map showing location of physiographic provinces and bridge-scour study sites in South Carolina

$2-5$. Graphs showing:

2. Median grain size of the original and second sediment samples

3. Relation of observed clear-water abutment-scour depth and the 100-year-flow embankment length in the Piedmont of South Carolina.

4. Relation of observed clear-water abutment-scour depth and the 100-year-flow embankment length for the Coastal Plain of South Carolina 
5. Relation of the predicted 100-year-flow abutment-scour depth and embankment length compared with the envelope of observed abutment scour for selected sites in the Piedmont of South Carolina.

6. Sketch showing embankment length and obstructed flow area determined by projection of the bridge cross section onto the approach cross section

7. Graph showing field observations of abutment-scour depth and predicted abutment-scour depth for the 100-year flow, computed with the original Froehlich equation with the factor of safety, for selected sites in the Piedmont and Coastal Plain of South Carolina .

8. Sketch showing determination of embankment length blocking live flow

9. Graph showing field observations of abutment-scour depth and predicted abutment-scour depth for the 100-year flow, computed with the modified Froehlich equation with the factor of safety, for selected sites in the Piedmont and Coastal Plain of South Carolina

10-11. Sketches showing:

10. Approach cross section with a well-defined low-flow channel, identifying areas used to determine hydraulic properties

11. Approach cross section for swampy site with no well-defined low-flow channel, identifying areas used to determine hydraulic properties

12. Graph showing field observations of abutment-scour depth and predicted abutment-scour depth for the 100-year flow, computed with the Sturm equation with the factor of safety, for selected sites in the Piedmont and Coastal Plain of South Carolina.....

13. Sketch showing approach cross section for swampy site with no well-defined low-flow channel, identifying the channel used in applying the Maryland equation .....18

14-15. Graphs showing:

14. Field observations of abutment-scour depth and predicted abutment-scour depth for the 100-year flow, computed with the Maryland equation with the factor of safety, for selected sites in the Piedmont and Coastal Plain of South Carolina

15. Field observations of abutment-scour depth and predicted abutment-scour depth for the 100-year flow, computed with the HIRE equation for selected sites in the Piedmont and Coastal Plain of South Carolina

16. Sketch showing definition of scour hole velocities, depths, and areas for equation 20 .

17. Graph showing field observations of abutment-scour depth and predicted abutment-scour depth for the 100-year flow, computed with the Young equation for selected sites in the Piedmont and Coastal Plain of South Carolina

18-22. Sketches showing:

18. Topography of abutment scour at structure 014020100300 on S.C. Route 201 crossing the Little River in Abbeville County, South Carolina

19. Topography of abutment scour at structure 254036300100 on S.C. Route 363 crossing the Coosawhatchie River in Hampton County, South Carolina

20. Topography of abutment scour at structure 277008700100 on Road S-87 crossing the Coosawhatchie River in Jasper County, South Carolina

21. Topography of abutment scour at structure 362017600400 on U.S. Route 176 crossing Indian Creek in Newberry County, South Carolina

22. Topography of abutment scour at structure 367008100200 on Road S-81 crossing the Enoree River in Newberry County, South Carolina 


\section{Tables}

1. Range of selected properties for clear-water abutment-scour data collected in the Piedmont and Coastal Plain of South Carolina ............................................................6

2. Sites for which two-dimensional flow models were developed.......................................22

3. Selected basin characteristics for sites with two-dimensional flow models ..................23

4. Selected abutment data for sites with two-dimensional flow models .............................23

\section{Conversion Factors, Temperature, Vertical Datum, and Abbreviations and Acronyms}

\begin{tabular}{lcl}
\hline \multicolumn{1}{c}{ Multiply } & By & \multicolumn{1}{c}{ To obtain } \\
\hline & Length & \\
inch (in.) & 25.4 & millimeter $(\mathrm{mm})$ \\
foot (ft) & 0.3048 & meter $(\mathrm{m})$ \\
mile (mi) & 1.609 & kilometer $(\mathrm{km})$ \\
& Area & \\
square mile $\left(\mathrm{mi}^{2}\right)$ & 2.590 & square kilometer $\left(\mathrm{km}^{2}\right)$ \\
& Volume & \\
cubic foot $\left(\mathrm{ft}^{3}\right)$ & 0.02832 & cubic meter $\left(\mathrm{m}^{3}\right)$ \\
& Flow rate & \\
cubic foot per second $\left(\mathrm{ft}^{3} / \mathrm{s}\right)$ & 0.02832 & cubic meter per second $\left(\mathrm{m}^{3} / \mathrm{s}\right)$ \\
foot per second $(\mathrm{ft} / \mathrm{s})$ & 0.3048 & meter per second $(\mathrm{m} / \mathrm{s})$ \\
\hline
\end{tabular}

Equations for temperature conversion between degrees Celsius $\left({ }^{\circ} \mathrm{C}\right)$ and degrees Fahrenheit $\left({ }^{\circ} \mathrm{F}\right)$ :

$$
\begin{aligned}
& { }^{\circ} \mathrm{C}=5 / 9\left({ }^{\circ} \mathrm{F}-32\right) \\
& { }^{\circ} \mathrm{F}=\left(1.8 \mathrm{x}^{\circ} \mathrm{C}\right)+32
\end{aligned}
$$

Vertical coordinate information is referenced to the National Geodetic Vertical Datum of 1929 (NGVD of 1929). 


$\begin{array}{ll}\text { Abbreviations and Acronyms: } \\ \text { ABSCOUR } & \text { Maryland State Highway Administration's abutment-scour computer program } \\ \text { ASTM } & \text { American Society for Testing and Materials } \\ \text { EFA } & \text { Erosion Function Apparatus } \\ \text { FHWA } & \text { Federal Highway Administration } \\ \text { HEC } & \text { Hydraulic Engineering Circular } \\ \text { HIRE } & \text { Highways in the River Environment } \\ \text { SCBSD } & \text { South Carolina Bridge-Scour Database } \\ \text { SCDOT } & \text { South Carolina Department of Transportation } \\ \text { SMS } & \text { Surface-Water Modeling System } \\ \text { SRICOS } & \text { Scour-Rate-In-Cohesive-Soils method } \\ \text { USGS } & \text { U.S. Geological Survey } \\ \text { WSPRO } & \text { Water-Surface Profile model } \\ \text { mm } & \text { millimeter }\end{array}$




\title{
Trends of Abutment-Scour Prediction Equations Applied to 144 Field Sites in South Carolina
}

\author{
By Stephen T. Benedict', Nikhil Deshpande ${ }^{2}$, Nadim M. Aziz ${ }^{3}$, and Paul A. Conrads ${ }^{4}$
}

\section{Abstract}

The U.S. Geological Survey conducted a study in cooperation with the Federal Highway Administration in which predicted abutment-scour depths computed with selected predictive equations were compared with field measurements of abutment-scour depth made at 144 bridges in South Carolina. The assessment used five equations published in the Fourth Edition of "Evaluating Scour at Bridges," (Hydraulic Engineering Circular 18), including the original Froehlich, the modified Froehlich, the Sturm, the Maryland, and the HIRE equations. An additional unpublished equation also was assessed. Comparisons between predicted and observed scour depths are intended to illustrate general trends and orderof-magnitude differences for the prediction equations. Field measurements were taken during non-flood conditions when the hydraulic conditions that caused the scour generally are unknown. The predicted scour depths are based on hydraulic conditions associated with the 100-year flow at all sites and the flood of record for 35 sites. Comparisons showed that predicted scour depths frequently overpredict observed scour and at times were excessive. The comparison also showed that underprediction occurred, but with less frequency. The performance of these equations indicates that they are poor predictors of abutment-scour depth in South Carolina, and it is probable that poor performance will occur when the equations are applied in other geographic regions. Extensive data and graphs used to compare predicted and observed scour depths in this study were compiled into spreadsheets and are included in digital format with this report. In addition to the equationcomparison data, Water-Surface Profile Model tube-velocity data, soil-boring data, and selected abutment-scour data are included in digital format with this report. The digital database was developed as a resource for future researchers and is especially valuable for evaluating the reasonableness of future equations that may be developed.

\section{Introduction}

Current methods for estimating abutment-scour depths are based on equations derived from laboratory investigations. These equations have not been verified for field conditions, casting some doubt on their applicability to the field setting. Field data to properly test various abutment-scour equations are not available. In the late 1990s, the U.S. Geological Survey (USGS), in cooperation with the South Carolina Department of Transportation (SCDOT), collected 209 observations of clear-water abutment-scour depth at 144 bridges in the Piedmont and Coastal Plain of South Carolina (Benedict, 2003; fig. 1; Appendix A). (Two sites fall within the boundary of the Blue Ridge Province but have characteristics similar to Piedmont sites and, therefore, were classified as Piedmont sites.) The observed scour depths were associated with hydraulic variables estimated from a water-surface profile model. The field observations, in conjunction with the hydraulic models, provide a means for evaluating various prediction equations. Although limitations exist in the South Carolina data, the large number of observations will allow an assessment of the general trends of a given equation.

Realizing the potential use of the South Carolina data, the USGS, in cooperation with the Federal Highway Administration (FHWA), initiated a study to assess the performance of selected abutment-scour equations. The assessment included five equations published in Hydraulic Engineering Circular 18 (HEC-18; Richardson and Davis, 2001), including the original Froehlich, the modified Froehlich, the Sturm, the Maryland, and the HIRE equations. An additional unpublished equation - the Young equation-also was assessed. Predicted abutment scour was computed using the 100-year flow at all bridges and the maximum historic flow at 35 bridges where historic flow data were available. Variables used in the equation computations along with results and graphs are compiled in digital spreadsheets and files. Descriptions of and links to the digital data are included in Appendix B.

\footnotetext{
${ }^{1}$ Hydrologist, U.S. Geological Survey, Suite 200, 405 College Avenue, Clemson, SC 29631.

2 Civil engineer, Rinker Design Associates, PC, Suite 300, 9300 West Courthouse Road, Manassas, VA 20110.

${ }^{3}$ Professor of Civil Engineering, Clemson University, 310 Lowry Hall, Clemson, SC 29634.

${ }^{4}$ Hydrologist, U.S. Geological Survey, Suite 129, 720 Gracern Road, Columbia, SC 29210.
} 


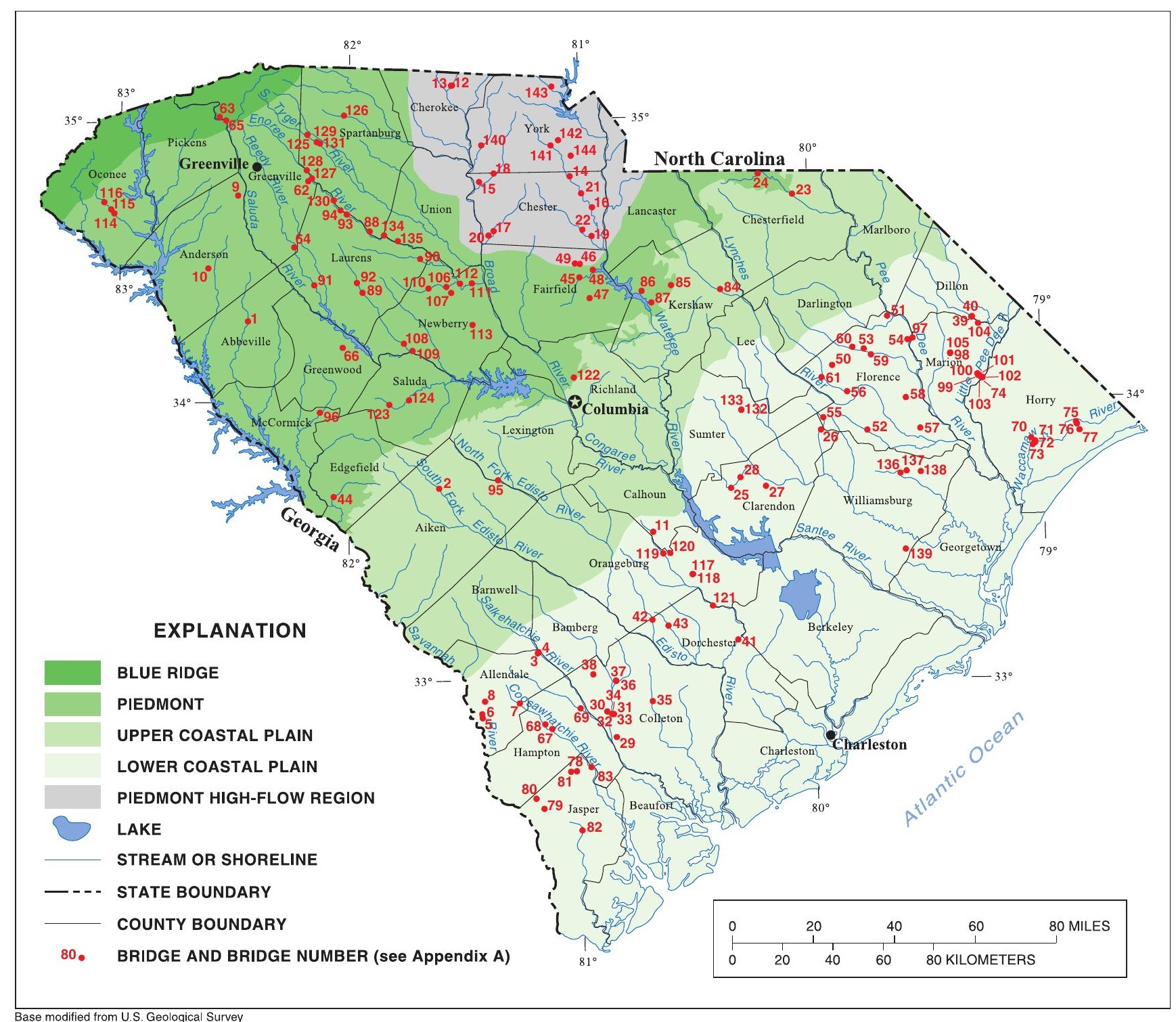

Base modified from U.S. Geological Survey
digital data, $1: 2,000,000$ scale, 1972

Figure 1. Location of physiographic provinces and bridge-scour study sites in South Carolina. (Refer to Appendix A at back of report for identification of bridge sites; Benedict, 2003.)

In addition to making equation assessments, selected data for each bridge site were compiled into digital format to help facilitate future research in abutment scour. These data include Water-Surface Profile (WSPRO; Shearman, 1990) tube-velocity data, soil-boring data, selected abutment-scour data, and estimates of sediment threshold velocities based on selected predictive methods. The WSPRO tube-velocity data include selected hydraulic variables and the velocity and area distributions at the approach and bridge cross sections. Graphs of the velocity and area distributions, and approximate groundsurface cross sections for the bridge and approach sections can be viewed in the digital spreadsheets. These data provide some understanding of the flow conditions at each bridge. The soil-boring data present tabulation of selected SCDOT bridge-plan boring logs in close proximity to observed scour and provide some understanding of soil conditions at each site. The abutment-scour data tabulate selected field and hydraulic data providing information on site conditions associated with the observed scour. The sediment threshold velocity data that are tabulated with the abutment-scour data provide estimates of critical and permissible velocities for the median grain size of sediments at each site by using selected predictive methods identified in a limited literature review. Descriptions of and links to the digital spreadsheets containing the WSPRO tubevelocity data, soil-boring data, selected abutment-scour data, and threshold velocity data are included in Appendix C. The findings of the limited literature review on threshold velocities 
and a comparison of critical and permissible velocities for selected predictive methods are included in Appendix D.

As supplemental data for future research, soil erosion rates for surface soils were determined at five South Carolina bridge sites where abutment-scour data were previously collected. These sites are located in the Piedmont region of South Carolina where soils have some measure of cohesion. A description of these sites and results of these tests are included in Appendix E. The results of the soil erosion tests are tabulated in digital spreadsheets, and links to the digital data are included in Appendix E.

Two-dimensional flow models also were developed for five of the South Carolina bridge sites by using the SurfaceWater Modeling System (SMS) model (Brigham Young University, 2000). These models were developed in anticipation of future research in which predicted scour computed with two-dimensional hydraulic variables would be compared with predicted scour computed with one-dimensional hydraulic variables. A general description of model development and site characteristics is provided in this report. The input data for each of the five models and the output from preliminary runs were transmitted to the FHWA but are not analyzed or presented in this report.

In addition, GKY and Associates, Inc., under contract with the FHWA, developed 10 two-dimensional flow models at South Carolina bridge sites where abutment-scour data were previously collected. One-dimensional and two-dimensional model results were compared and documented in a paper written by Dr. Xibing S. Dou, Senior Research Engineer for GKY and Associates, Inc. This paper was provided to the USGS by the FHWA and is included as information in Appendix F.

\section{Purpose and Scope}

The purpose of this report is to (1) briefly describe the field and hydraulic data compiled and used in this study and note the limitations of these data; (2) describe the equations used in the comparison of predicted and observed scour and the techniques used to apply the equations; (3) briefly describe the development of two-dimensional models at five sites; and (4) describe the contents of digital spreadsheets that contain the compiled data and the equation comparisons. Links to the digital spreadsheets are included in Appendixes B and C. These spreadsheets contain a large volume of data, along with various graphs, providing a valuable resource for those investigating abutment scour.

\section{Previous Investigations}

A recent literature review of published field data for abutment scour (D.S. Mueller, U.S. Geological Survey, written commun., 2002) concluded that "complete and reliable field data are rare." Excluding the data recently collected in South Carolina (Benedict, 2003), only three references were found that contain published field data related to abutment scour. These references included data for nine bridge sites that had significant contractions of flow. Only two of the nine sites had comparisons between predicted and observed abutment-scour depths. Although it is probable that there are unpublished field data for abutment scour, the findings of the literature review indicate that published field data (excluding the South Carolina data) are limited and insufficient to assess the performance of abutment-scour prediction equations. This underscores the value of the field data collected in South Carolina and the importance of this study in assessing selected abutment-scour prediction equations.

\section{South Carolina Field Data}

Predictive abutment-scour equations have been derived primarily from laboratory studies. Investigations of abutment scour in the controlled environment of the laboratory allow the precise measurement of selected properties, such as flow depth, flow velocity, grain size, and scour depth. These measured properties are used in turn to define correlations and derive prediction equations. When collecting field data, it would be advantageous to target properties similar to those typically collected in the laboratory and used in the development of the prediction equations. Measuring these properties in the field setting, however, is a difficult task that often cannot be accomplished to the same degree of accuracy and thoroughness as that of laboratory measurements. Because field observations often have limitations, it is important to understand field data characteristics when using the data to verify laboratory-derived equations. To facilitate this understanding, a summary of the characteristics for the data collected in South Carolina follows. For additional information and a more detailed description of the data, refer to Benedict (2003).

A total of 209 observations of clear-water abutment scour were made at 144 bridges in the Piedmont and Coastal Plain of South Carolina-65 in the Piedmont and 79 in the Coastal Plain. Observed clear-water abutment-scour depths ranged from 0 to 23.6 feet $(\mathrm{ft})$. The measured data represent the maximum clear-water abutment-scour depth that occurred at each bridge since construction. In general, observations of abutment-scour were located in close proximity to the abutment toe and outside of the main channel. The reference surface used to determine the scour depth was the average undisturbed flood-plain elevation in the vicinity of the observed scour. The flood plains of South Carolina typically are covered by thick vegetation that impedes the transport of sediments and promotes clear-water scour conditions. Although flood-plain approach velocities blocked by road embankments often were sufficiently low to create clear-water scour conditions (the average 100-year approach velocity blocked by the road embankment for the 209 observations of abutment scour was 0.6 foot per second ( $\mathrm{ft} / \mathrm{s})$ ), the classification of sites in this study as clear-water scour was based primarily on the impediment of sediment transport by site conditions. This 
classification was corroborated by the limited amount of infill observed at most sites. In general, infill sediments within the scour holes were negligible; measured infill depths ranged from 0.0 to $4.6 \mathrm{ft}$ with a mean of $0.4 \mathrm{ft}$ and median of $0 \mathrm{ft}$. When observed, the infill sediment depth was measured and the scour hole depth was adjusted to account for the infill. The dominant abutment geometry in the South Carolina data was the spill-through abutment (141 bridges); the remaining 3 bridges were vertical abutments with wingwalls.

\section{Sediment Samples}

Grab samples of sediments in the approach flood plain were obtained at each site and analyzed to estimate the median grain size. Sediments in the field setting typically are non-homogeneous, and grain-size characteristics can vary rapidly with depth and lateral location. Therefore, it is possible that the grab samples obtained for the South Carolina data do not fully represent the sediments at a given site. During the data-collection phase of the study, the analysis of grain-size distributions for sediment samples was limited to grain sizes greater than or equal to 0.062 millimeter ( $\mathrm{mm})$. This is the breakpoint between the sand and silt/clay soils. For most Coastal Plain sites, this analysis was adequate for defining the median grain size $\left(\mathrm{D}_{50}\right)$. However, this size occasionally was inadequate for clayey Piedmont soils where the $\mathrm{D}_{50}$ can be smaller than $0.062 \mathrm{~mm}$. At such sites, the $\mathrm{D}_{50}$ was assumed to be equal to $0.062 \mathrm{~mm}$, and clear-water contraction scour was computed for this grain size. In an attempt to better understand and define the clay content of Piedmont soils, second visits were made to all Piedmont sites and a second grab sample was obtained and analyzed for the full range of grain size. (In this report, the first sample is referred to as the initial or original sediment sample (sample 1), and the revisit sample is called the second sample (sample 2).)

In figure 2 , the $\mathrm{D}_{50}$ of the original sample is compared with that of the second sample. Although the second set of samples was obtained in close proximity to the original sample, there often was poor agreement in sediment size, and differences sometimes varied by an order of magnitude. This discrepancy in grain size between multiple samples at the same site highlights the non-homogeneity of flood-plain soils and indicates that grain-size analyses should be viewed with caution. Because of this discrepancy, results obtained from scour-predicting equations that use $\mathrm{D}_{50}$ as an explanatory variable also should be viewed with caution. The digital soil-boring data included in Appendix $\mathrm{C}$ can be used to gain additional insight about soil conditions at a given site. These data include descriptions of the various soil layers in the boring as well as the thickness of each layer.

All of the predictive abutment-scour equations assessed in this study were derived for non-cohesive soil conditions and likely will perform poorly when applied to sites with cohesive soils. This limitation should be kept in mind when reviewing the equation computations for the Piedmont data where soils typically are cohesive.

\section{Hydraulic Data}

Because abutment-scour depths were measured during low flows, the flow conditions that created the scour are not known. To gain insights into hydraulic conditions that may have created the observed scour, hydraulic models were developed for each site by using the one-dimensional stepbackwater model, WSPRO (Shearman, 1990). The 100-year flow was used in the WSPRO model as a common flow condition for the bridges. In addition, estimated maximum historic flows since bridge construction were available at 35 sites, and these flows also were used in the WSPRO model. The maximum historic flows often were determined by indirect methods for estimating peak flows, and it is possible that error

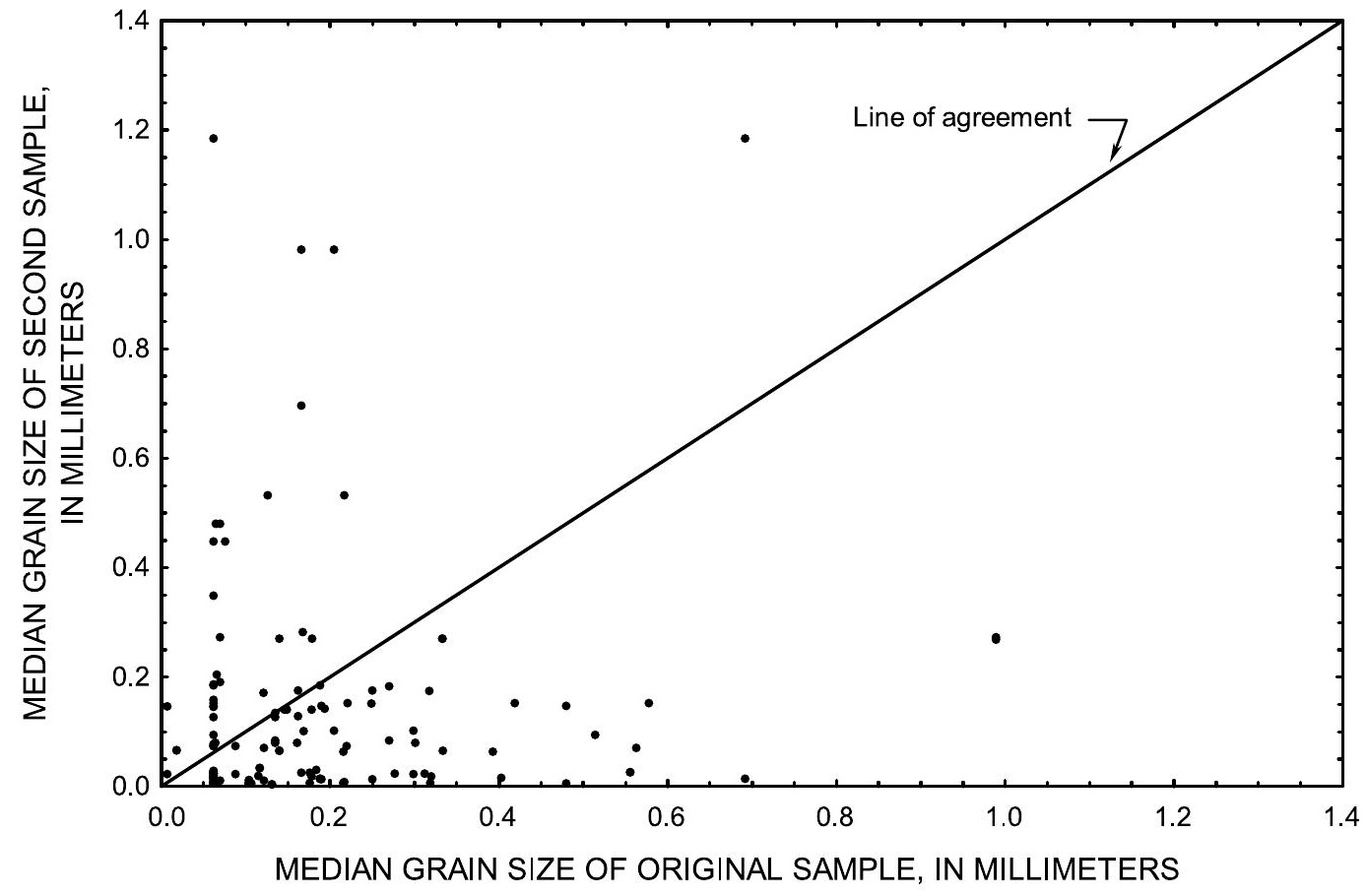

Figure 2. Median grain size of the original and second sediment samples (Benedict, 2003). 
exists within these estimates. All hydraulic variables used in this study were derived from the WSPRO model and should be viewed as approximate rather than measured data. Although the estimated hydraulic data are likely to introduce error into the predicted scour computations, the large number of field observations (209) used in the comparisons will allow any trends characteristic of a particular equation to be assessed.

The digital spreadsheets containing the WSPRO (Shearman, 1990) tube-velocity data, included in Appendix C, can be used to gain understanding about flow conditions at each site. These data include selected hydraulic properties for the approach and bridge cross sections, as well as the velocity and area distributions generated by the equal-conveyance tube routine of the WSPRO model. The digital spreadsheets contain graphs of the velocity and area distributions, and approximate ground-surface cross sections for the bridge and approach sections for each bridge site. These data were compiled for the 100-year flow at all bridges and for the maximum historic flow since bridge construction at 35 bridges where historic flow data were available.

\section{Contraction and Pier Scour in the Abutment Area}

The measured abutment-scour depths in this study represent total scour at the abutment, including effects from contraction and pier scour. When assessing predicted scour at an abutment, it is commonly assumed that the various components of scour are independent and additive in nature (Richardson and Davis, 2001). Therefore, total predicted scour at an abutment is the summation of predicted pier scour, contraction scour, and abutment scour. Laboratory investigations also have sought to separate these components. In particular, laboratory investigators commonly have defined the abutment-scour component by subtracting observed contraction scour that has occurred beyond the abutment area from the total scour depth at the modeled abutment. This procedure assumes that the mechanism creating contraction scour beyond the abutment area also creates contraction scour in the abutment area. However, field observations in conjunction with the theory of flow patterns at short contractions indicate that this view of scour in the abutment area is inappropriate (Benedict, 2003). In particular, contraction scour, which is associated with rectilinear flow, should not be considered a contributing component of scour in the abutment area where flow is severely curved. In this study, no adjustment for contraction scour was made to field measurements of abutment-scour depths, and the measured scour depths reflect scour created primarily by local abutment scour in addition to any contributing pier scour. This possibly can be a point of confusion when comparing field data with various abutment-scour equations derived from laboratory data. Some laboratory investigators only used the abutment-scour component, as defined above, to derive prediction equations, while others used the total scour at the abutment. The data used to derive various equations as well as the differences between field and laboratory data should be kept in mind when comparing various laboratory relations with the field data in this report.

Measured abutment scour in this study includes the effect of piers. However, this effect is likely negligible at many sites and only minor at others (Benedict, 2003). The small pier widths (1 to $2.3 \mathrm{ft}$ ) associated with 85 percent of the bridge sites indicate that pier scour will have a limited effect on total scour at the abutment. In addition, piers commonly are located on the sides of abutment-scour holes rather than at the low point and, therefore, have a limited (or negligible) effect on total scour at the low point. The digital abutment-scour data included in Appendix $\mathrm{C}$ indicate whether a pier or pile bent is located at the low point of the abutment-scour hole. In addition, the South Carolina Bridge Scour Database (SCBSD; Benedict, 2003) contains scour-hole contour plots for 80 of the 144 bridge sites, indicating where piers or pile bents are located in relation to the measured scour. This information can be reviewed to gain understanding of the effect of pier scour on total abutment scour at a given site.

\section{Characteristics of the Piedmont and Coastal Plain Provinces}

The data collected in South Carolina have been grouped into two databases based on regional location within the State. One database contains data collected in the Piedmont Physiographic Province and the other contains data collected in the Coastal Plain Physiographic Province (fig. 1). (Two sites fall within the boundary of the Blue Ridge Province but have characteristics similar to Piedmont sites and, therefore, were classified as Piedmont sites.) This division of the data is justified because of the distinct regional characteristics of the Piedmont and Coastal Plain Provinces. The Piedmont generally has clayey, cohesive soils that tend to resist scour, flood-plain widths that are relatively narrow, and flood hydrographs that have relatively short flow durations. In contrast, the Coastal Plain generally has sandy soils that are scour susceptible, flood-plain widths that are relatively wide, and flood hydrographs that have relatively long flow durations. To provide some understanding of the differences between these regions, table 1 gives the median and range of selected properties for the field data collected in the Piedmont and Coastal Plain Provinces. 
Table 1. Range of selected properties for clear-water abutment-scour data collected in the Piedmont and Coastal Plain of South Carolina (modified from Benedict, 2003).

$\left[\mathrm{mi}^{2}\right.$, square mile; $\mathrm{ft} / \mathrm{ft}$, foot per foot; ft/s, foot per second; ft, foot; mm, millimeter; $<$, less than]

\begin{tabular}{|c|c|c|c|c|c|c|}
\hline \multirow{2}{*}{ Property } & \multicolumn{2}{|c|}{ Minimum value } & \multicolumn{2}{|c|}{ Median value } & \multicolumn{2}{|c|}{ Maximum value } \\
\hline & Piedmont & Coastal Plain & Piedmont & Coastal Plain & Piedmont & Coastal Plain \\
\hline Number of data-collection bridge sites & 65 & 79 & 65 & 79 & 65 & 79 \\
\hline $\begin{array}{l}\text { Number of observations of abutment } \\
\text { scour }\end{array}$ & 100 & 109 & 100 & 109 & 100 & 109 \\
\hline Drainage area $\left(\mathrm{mi}^{2}\right)$ & 11.0 & 6.0 & 74.9 & 120 & $1,620^{\mathrm{a}}$ & $8,830^{\mathrm{b}}$ \\
\hline $\begin{array}{l}\text { Channel slope determined from } \\
\text { topographic map }(\mathrm{ft} / \mathrm{ft})\end{array}$ & .00015 & .00007 & .0012 & .0005 & .0029 & .0024 \\
\hline $\begin{array}{l}\text { 100-year average approach velocity } \\
\text { obstructed by embankment }(\mathrm{ft} / \mathrm{s})^{\mathrm{c}}\end{array}$ & .1 & .1 & .9 & .5 & 3.2 & 1.6 \\
\hline $\begin{array}{l}\text { 100-year average approach depth } \\
\text { obstructed by embankment }(\mathrm{ft})^{\mathrm{c}}\end{array}$ & 1.0 & 1.5 & 5.4 & 4.7 & 14.6 & 17.4 \\
\hline $\begin{array}{l}\text { Embankment length based on 100-year } \\
\text { flow }(\mathrm{ft})^{\mathrm{c}}\end{array}$ & 18.0 & 87 & 276 & 557 & $953^{\mathrm{d}}$ & $7,440^{\mathrm{e}}$ \\
\hline Median grain size (mm) & $<.062$ & $<.062$ & .073 & .180 & .990 & .780 \\
\hline Observed abutment-scour depth (ft) & .0 & .0 & 1.3 & 7.0 & 18.0 & 23.6 \\
\hline
\end{tabular}

${ }^{\mathrm{a}}$ Approximately 97 percent of the study sites in the Piedmont have drainage areas less than $400 \mathrm{mi}^{2}$.

${ }^{\mathrm{b}}$ Approximately 80 percent of the study sites in the Coastal Plain have drainage areas less than $426 \mathrm{mi}^{2}$.

${ }^{c}$ Property was estimated from the one-dimensional water-surface profile model, WSPRO (Shearman, 1990).

${ }^{\mathrm{d}}$ Three observations have embankment lengths that exceed $953 \mathrm{ft}$ and are substantially outside the range for the majority of the Piedmont data.

${ }^{\mathrm{e}}$ Only seven observations have embankment lengths that exceed 2,000 ft.

\section{Envelope Curves of Field Data}

Laboratory investigations have identified variables that influence the development of abutment scour in the laboratory setting. This list of variables includes time, flow velocity, flow depth, sediment size, sediment gradation, embankment length, abutment shape, embankment skew, and channel geometry. Limited analysis of the field data collected in South Carolina indicated that many of these variables do not significantly influence scour depths (Benedict, 2003). The embankment length blocking flow, however, was found to be a strong indicator for scour potential. The data showed that as embankment length increased, the upper range of observed abutment-scour depth also increased. Envelopes of observed abutment-scour depth and embankment length were developed with the field data, and these envelopes provide a tool for assessing the upper range of observed scour depth for a given embankment length. Figures 3 and 4 (Benedict, 2003) present the envelope curves for the Piedmont and Coastal Plain, respectively. For

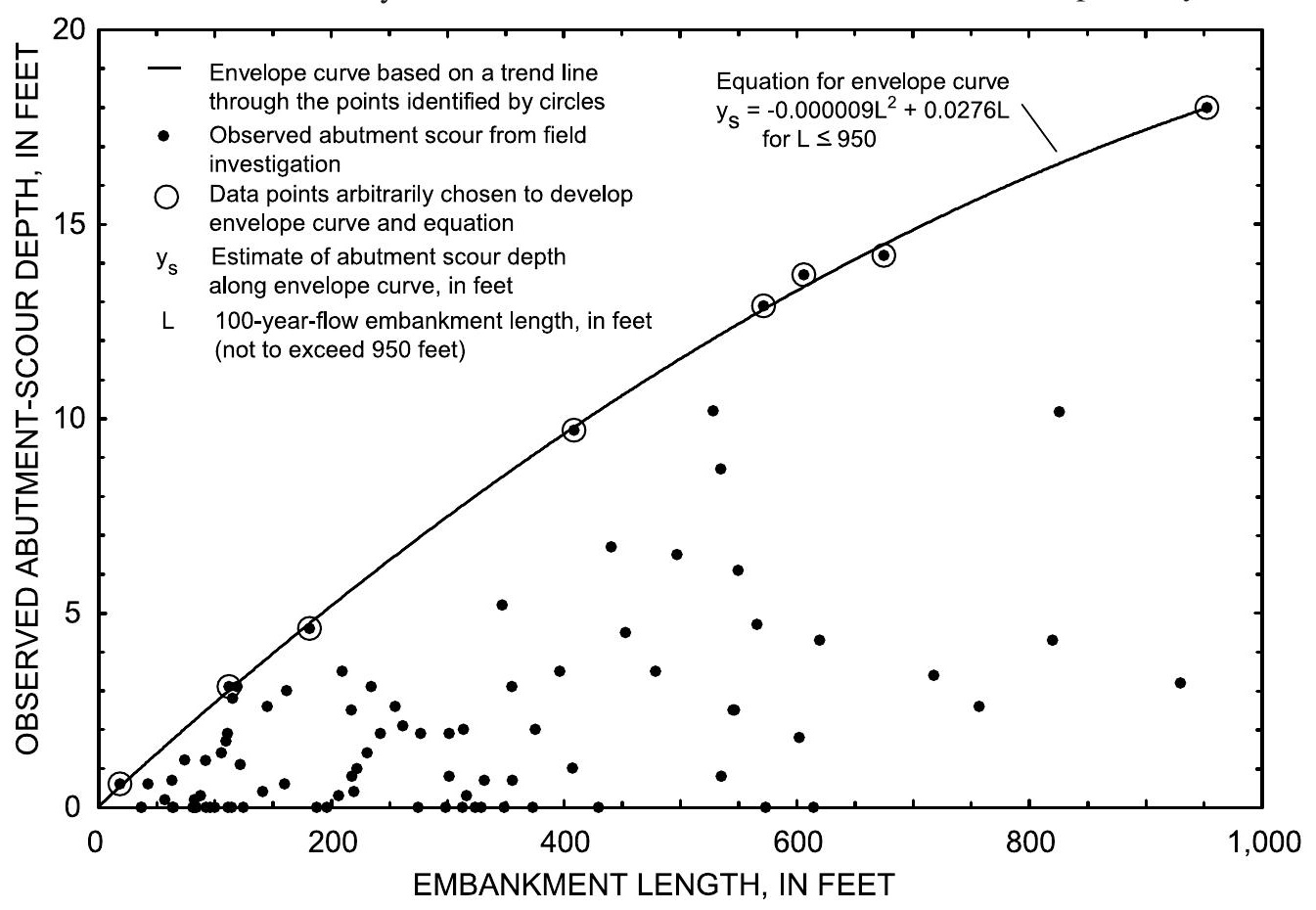

Figure 3. Relation of observed clear-water abutment-scour depth and the 100-year-flow embankment length in the Piedmont of South Carolina (Benedict, 2003). 


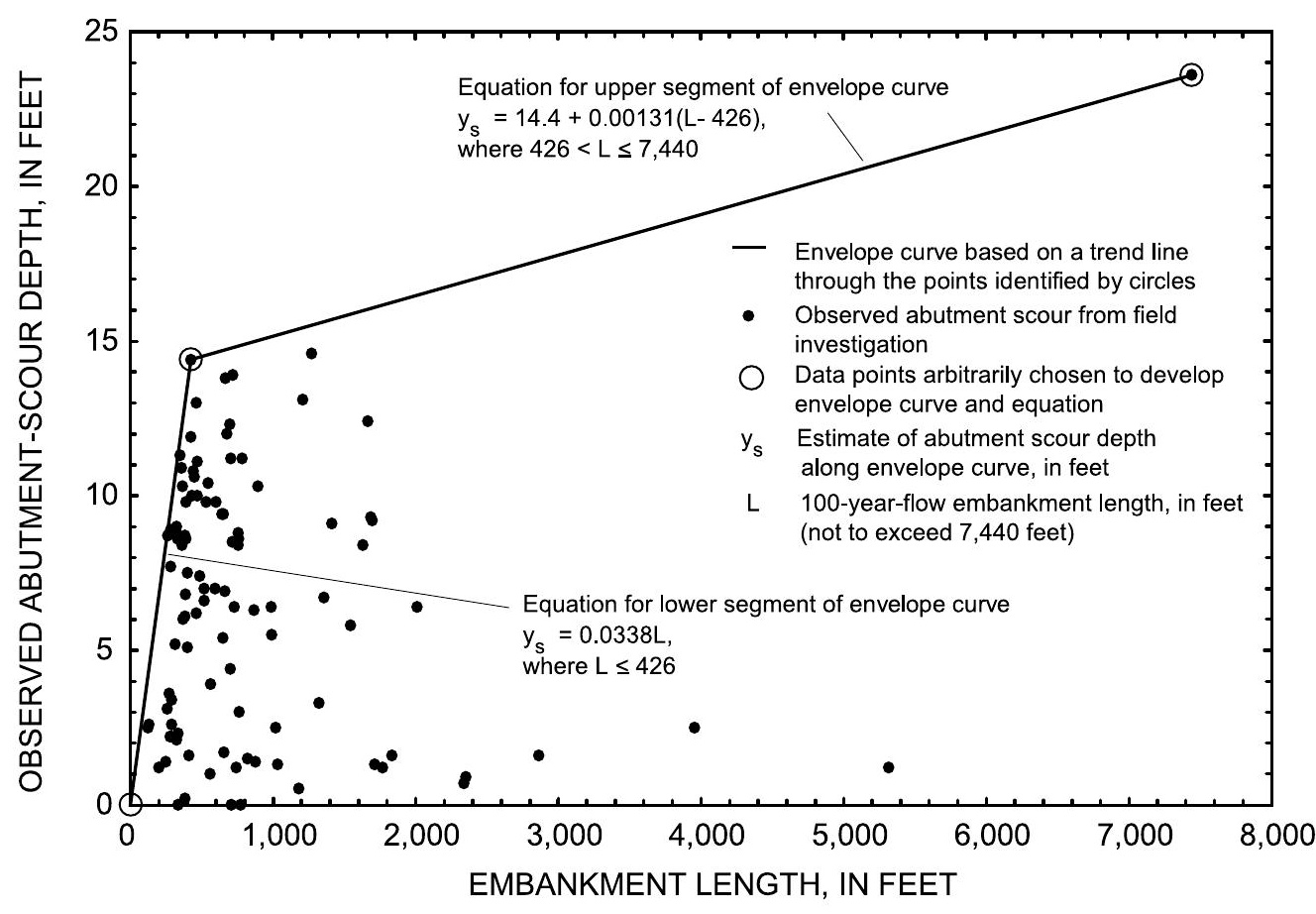

Figure 4. Relation of observed clear-water abutment-scour depth and the 100-year-flow embankment length for the Coastal Plain of South Carolina (Benedict, 2003). results of each abutment-scour equation were compared with the envelopes in figures 3 and 4 , and graphs of these comparisons are contained in the digital spreadsheets in Appendix B.

\section{South Carolina Bridge Scour Database}

The South Carolina Bridge Scour Database (SCBSD; Benedict, 2003) contains a large amount of data related to the 209 observations of abutment scour in South Carolina. The SCBSD includes photographs, scour hole contour plots at 80 sites, selected field data, limited basin characteristics, limited soil data, selected hydraulic data estimated with the WSPRO model (Shearman, 1990), and selected predicted scour computations. These raw data are compiled in various data tables within the database, and automated reports have been developed to allow extraction of selected data for a specific bridge. The SCBSD provides additional information additional information on the development of the envelopes, refer to Benedict (2003).

In addition to making one-to-one comparisons of observed and predicted abutment-scour depths, this study also compared the predicted scour depths with the envelopes in figures 3 and 4 . These comparisons are helpful in assessing whether a given equation is following trends in the field data in which large abutment-scour depths are associated with longer embankments. For example, figure 5 shows the comparison of the Piedmont predicted abutmentscour depths, computed with the original Froehlich equation (Richardson and Davis, 2001), compared with the Piedmont embankment envelope (Benedict, 2003). This comparison indicates that the original Froehlich equation tends to follow the trend of increasing abutment-scour depth with increasing embankment length. However, the overprediction can be significantly beyond the limit of the field data as defined by the envelope. The

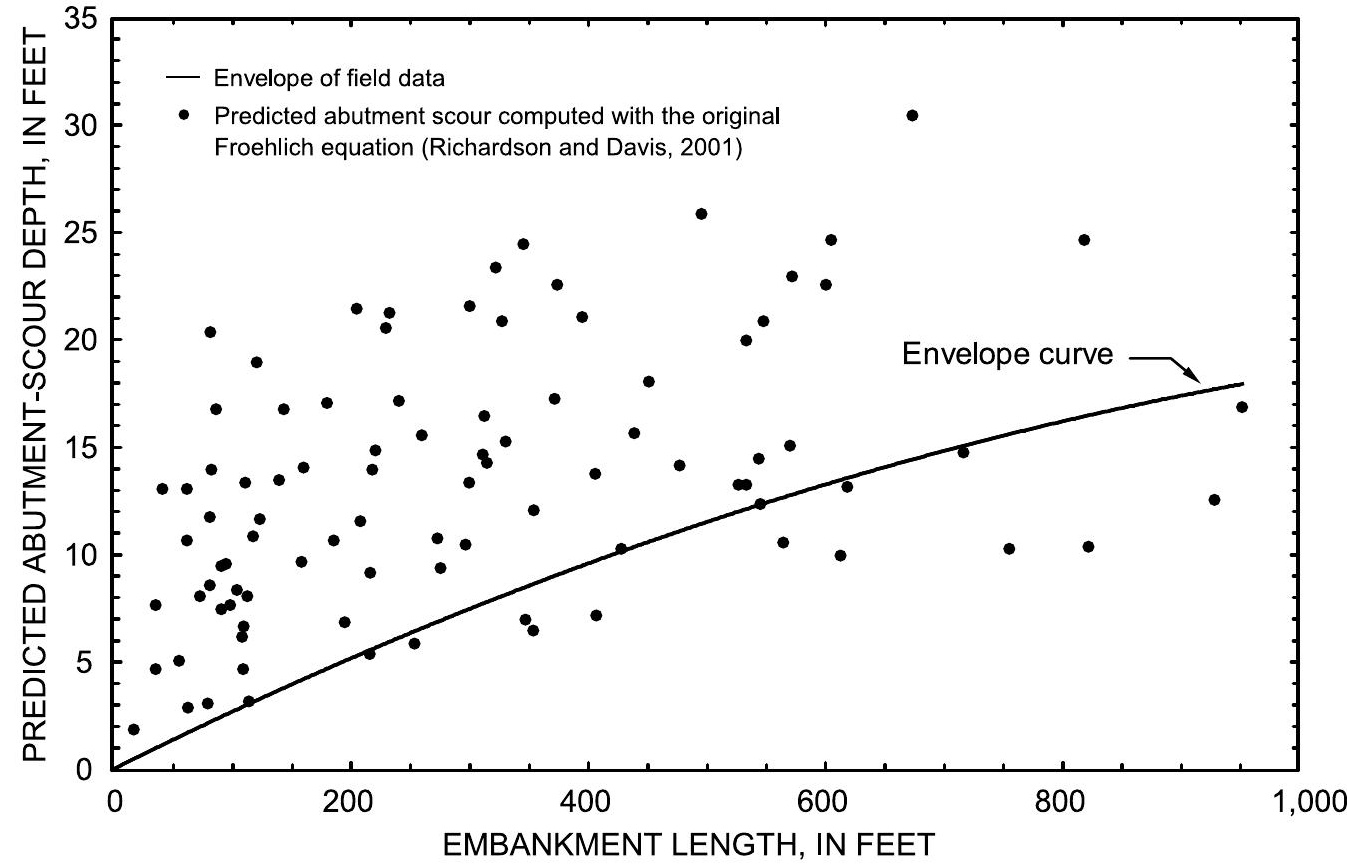

Figure 5. Relation of the predicted 100-year-flow abutment-scour depth and embankment length compared with the envelope of observed abutment scour for selected sites in the Piedmont of South Carolina (Benedict, 2003). 
on the bridges in the current study and should be viewed as a companion database.

\section{Abutment Scour Prediction Equations}

In HEC-18, Richardson and Davis (2001) present five equations for predicting abutment-scour depth, including the original Froehlich, the modified Froehlich, the Sturm, the Maryland, and the HIRE equations. These equations, along with the unpublished Young equation, were used to compute predicted abutment-scour depths for the South Carolina data and compare them with the observed scour depths. The data in the Piedmont and Coastal Plain of South Carolina were analyzed as separate regional data sets. The analysis of each regional data set included comparisons of observed scour with predicted scour computed with the 100-year flow at all sites, and predicted scour computed with the maximum historic flow since bridge construction at selected sites where information was available. Digital spreadsheets containing the computational variables, equation results, and comparisons of observed and predicted scour depths are included in Appendix B. A summary of each equation and a description of how they were applied to the South Carolina data follow.

\section{Original Froehlich Equation}

The original Froehlich equation (Froehlich, 1989; Richardson and Davis, 2001) was developed from a multiple linear regression analysis of 170 laboratory measurements of live-bed abutment scour in non-cohesive sediments. The laboratory data used in the analysis represented the component of abutment scour only, which typically was estimated by subtracting contraction scour observed outside of the abutment area from the total scour measured at the abutment. Although the equation initially was derived for the analysis of live-bed abutment scour in HEC-18, Richardson and Davis (2001) recommend its use for assessing both live-bed and clearwater abutment scour. The regression equation predicts the maximum depth of local scour at an abutment and is defined below as:

$$
\frac{y_{s}}{y_{a}}=2.27 K_{1} K_{2}\left[\frac{L}{y_{a}}\right]^{0.43} F r^{0.61},
$$

where

$y_{s}$ is the local abutment-scour depth, in feet (without the contraction-scour component);

$y_{a}$ is the average depth of flow on the flood plain upstream from the abutment, in feet;

$K_{1}$ is the dimensionless correction factor for abutment shape;

$K_{2}$ is the dimensionless correction factor for the angle of embankment to flow;
$L$ is the length of the embankment projected normal to flow, in feet; (Many laboratory investigations define the road embankment that blocks approaching flows as the abutment length. In this report, the term embankment length is used.) and

$\mathrm{Fr}$ is the Froude number of the flow upstream from the embankment, which is defined as:

$$
F r=V_{e} /\left(g y_{a}\right)^{0.5},
$$

where

$g$ is the acceleration due to gravity, in feet per square second, and

$V_{e}$ is the average flow velocity upstream from the embankment, in feet per second, and is defined as:

where

$$
\mathrm{V}_{\mathrm{e}}=\mathrm{Q}_{\mathrm{e}} / \mathrm{A}_{\mathrm{e}}
$$

$Q_{e}$ is the flow obstructed by the embankment, in cubic feet per second; and

$A_{e}$ is the flow area obstructed by the embankment, in square feet.

This regression equation encompassed only 45 percent of the laboratory data, which was undesirable for design and safety purposes. Therefore, a safety factor of 1 was added to force the equation to encompass 98 percent of the laboratory data. The safety factor increases the computed maximum scour depth by the addition of the approaching flow depth. The final form of the equation is as follows:

$$
\frac{y_{s}}{y_{a}}=2.27 K_{1} K_{2}\left[\frac{L}{y_{a}}\right]^{0.43} F r^{0.61}+1 \text {, }
$$

where all variables are defined in equation 1.

When applying the original Froehlich equation (Richardson and Davis, 2001) to the South Carolina data, equation variables were determined in the following manner. The length of the embankment $(L)$ was determined by projecting the bridge cross section onto the approach cross section and using the distance from edge of water to the projected abutment toe as the embankment length (fig. 6). The obstructed flow area $\left(A_{e}\right)$ was determined by using the approach cross-section geometry and water-surface elevation to calculate the flow area across the embankment length (fig. 6). The obstructed flow $\left(Q_{e}\right)$ was determined by prorating the total approach flow by the ratio of conveyance across the embankment length to that of the entire approach cross section. The average flow depth $\left(y_{a}\right)$ on the approach flood plain was determined by dividing the obstructed area by the embankment length. Once the above variables were determined, all other variables were calculated and applied within the equation. Abutment-scour computations with the original Froehlich equation were made with and without the safety factor. 


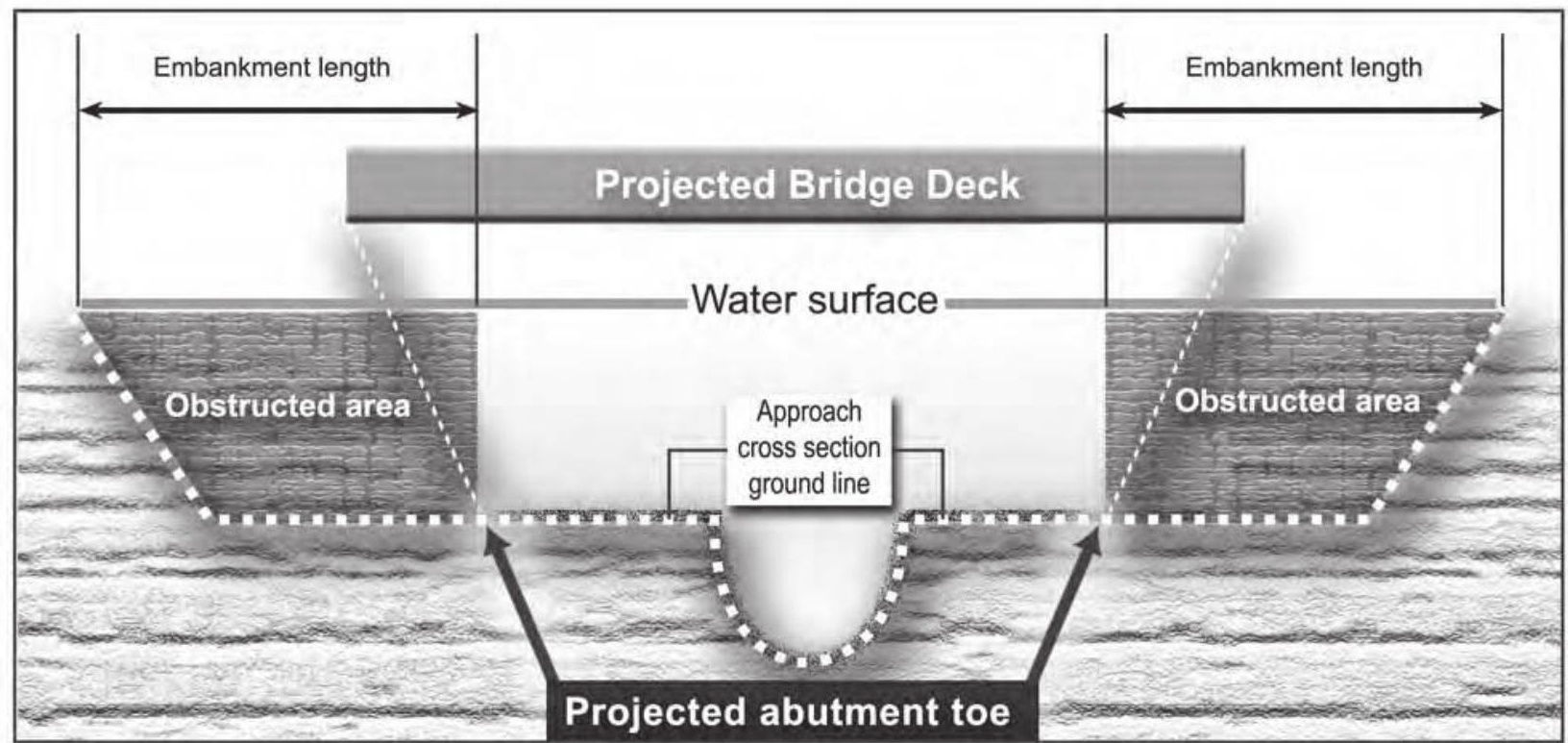

Figure 6. Embankment length and obstructed flow area determined by projection of the bridge cross section onto the approach cross section.

Predicted abutment-scour depths computed with the original Froehlich equation (Richardson and Davis, 2001) were compared with abutment-scour depths observed in the Piedmont and Coastal Plain of South Carolina (fig. 7). Predicted scour in figure 7 was computed with the 100-year flow and includes the safety factor. Additional figures and computational data for the 100-year flow and maximum historic flow are included in the digital spreadsheets in Appendix B.

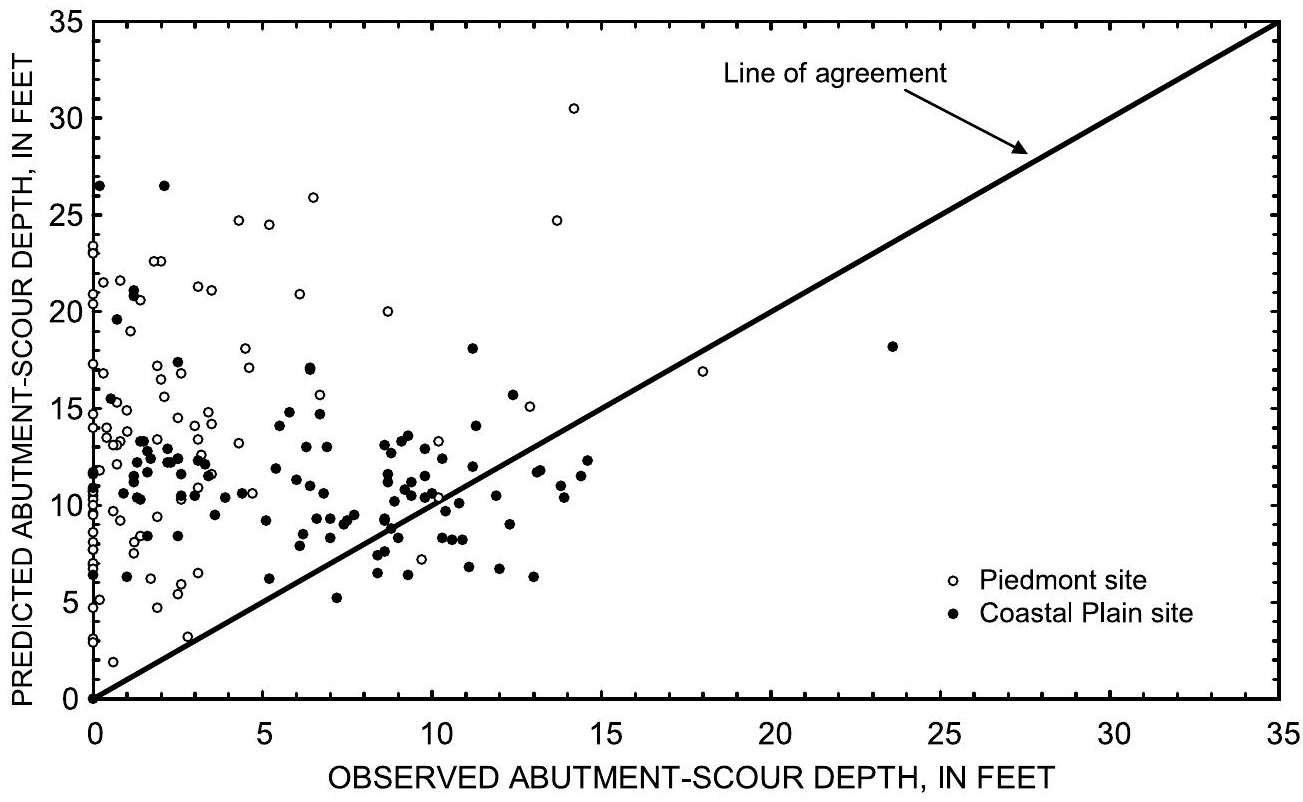

Figure 7. Field observations of abutment-scour depth and predicted abutment-scour depth for the 100-year flow, computed with the original Froehlich equation (Richardson and Davis, 2001) with the factor of safety, for selected sites in the Piedmont and Coastal Plain of South Carolina. 


\section{Modified Froehlich Equation}

The original Froehlich equation (Richardson and Davis, 2001) was derived from data measured in laboratory flumes having rectangular cross sections and uniform bed roughness. Under these conditions, approach flows generally are uniformly distributed, and the entire approach cross section conveys flow. In wide, natural flood plains, however, flows are not uniformly distributed, and the edge of the cross section is often ineffective in conveying flow. This ineffective flow area can be relatively wide, which reduces the effective embankment length that blocks live flow. To account for this, in HEC-18, Richardson and Davis (2001) recommend that the embankment length, as defined in the original Froehlich equation (Richardson and Davis, 2001), be modified to represent the length of embankment blocking "live" flow $\left(L^{\prime}\right)$, while using the other variables as previously defined for the original Froehlich equation. The variables $Q_{e}, V_{e}$, and $y_{a}$ are computed using the entire embankment length, $L$, rather than $L^{\prime}$. The modified Froehlich equation (Richardson and Davis, 2001) is as follows:

$$
\frac{y_{s}}{y_{a}}=2.27 K_{1} K_{2}\left[\frac{L^{\prime}}{y_{a}}\right]^{0.43} F r^{0.61}+1,
$$

where

$$
\begin{aligned}
& L^{\prime} \text { is the embankment length blocking live flow, } \\
& \text { in feet, and all other variables are defined in } \\
& \text { equation } 1 .
\end{aligned}
$$

To determine $L^{\prime}$, Richardson and Davis (2001) recommend two methods. The first method involves the visual inspection of a graph displaying equal-conveyance velocity tubes for flow approaching the bridge. This graph can be generated from data calculated by a one-dimensional flow model and commonly will identify areas of low velocity that may be ineffective for conveying flow (fig. 8). The width of these ineffective areas can be subtracted from the full embankment length, $L$, to determine $L^{\prime}$. HEC-18 gives only general guidance on defining ineffective flow areas using velocity

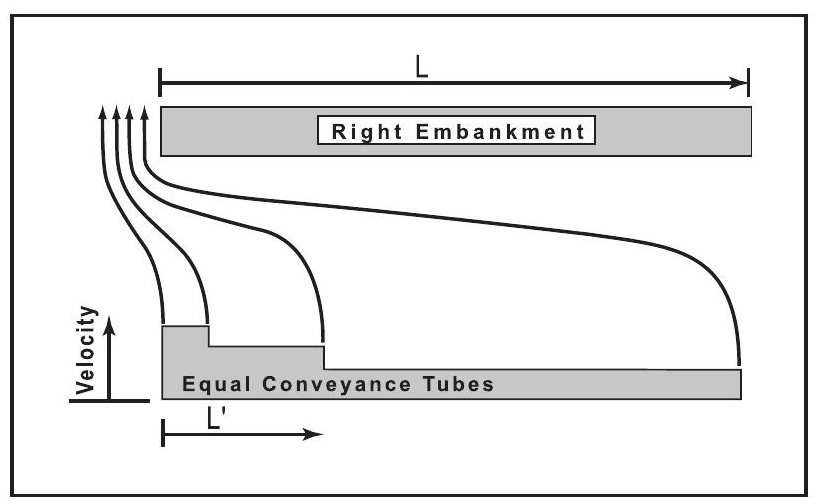

Figure 8. Determination of embankment length blocking live flow (Richardson and Davis, 2001). distribution plots and recommends that if an equal-conveyance velocity tube at the approach cross section is relatively wide or has a relatively small velocity, then that part of the embankment "should probably not be included" when determining the length of embankment blocking flow. If this method does not identify ineffective flow areas, Richardson and Davis (2001) recommend estimating $L^{\prime}$ by multiplying the width of the conveyance tube directly upstream from the abutment toe by the number of conveyance tubes (including fractional parts of tubes) obstructed by the road embankment.

When applying the modified Froehlich equation (Richardson and Davis, 2001) to the South Carolina data, equation variables were obtained in the same manner as defined for the original Froehlich equation (Richardson and Davis, 2001). However, to define the embankment length blocking live flow, $L^{\prime}$, graphs of the equal-conveyance velocity tubes for the approach cross section were visually inspected to determine the ineffective flow areas and, in turn, to adjust $L$ (fig. 8). A second estimate of $L^{\prime}$ was obtained by multiplying the width of the conveyance tube directly upstream from the abutment toe by the number of conveyance tubes obstructed by the road embankment. Occasionally, this method provided an embankment length that exceeded the unadjusted embankment length, $L$. In such cases, $L^{\prime}$ was set equal to $L$. Predicted abutment-scour depth was computed using both estimates of $L^{\prime}$. The following procedure was used to select the final estimate of predicted abutment-scour depth. If the visual inspection of the velocity-tube graph indicated an ineffective flow area, then predicted abutment scour computed by this method was selected. If the velocity-tube graph did not indicate an ineffective flow area, then predicted scour computed with the second estimate of $L^{\prime}$ was selected. Graphs of the equal-conveyance velocity tubes are included in the digital spreadsheets in Appendix B. These graphs include the projection of the bridge top width onto the approach velocity distribution, as well as the projections of $L$ and $L^{\prime}$.

Predicted abutment-scour depths computed with the modified Froehlich equation (Richardson and Davis, 2001) were compared with abutment-scour depths observed in the Piedmont and Coastal Plain of South Carolina (fig. 9). Predicted scour in figure 9 was computed with the 100-year flow and includes the safety factor. Additional figures and computational data for the 100-year flow and maximum historic flow are included in the digital spreadsheets in Appendix B. 


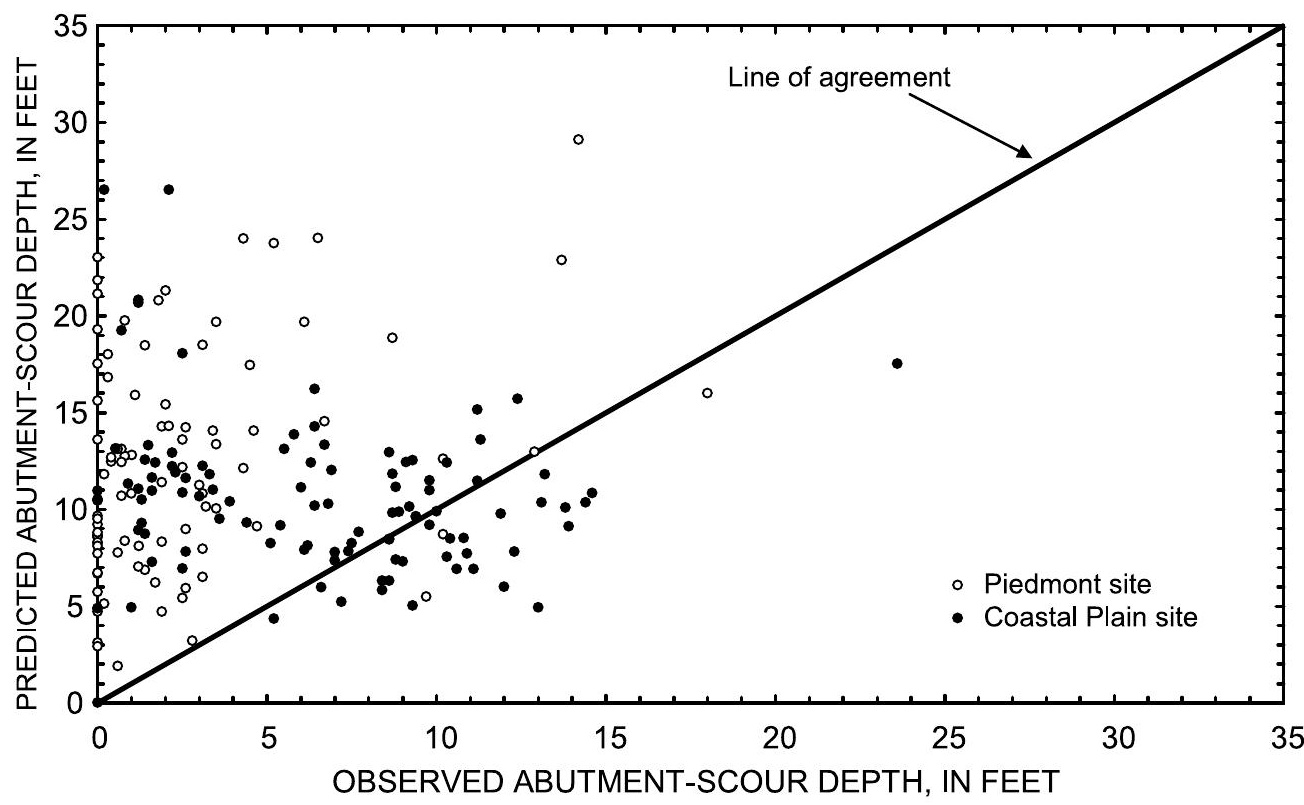

Figure 9. Field observations of abutment-scour depth and predicted abutment-scour depth for the 100-year flow, computed with the modified Froehlich equation (Richardson and Davis, 2001) with the factor of safety, for selected sites in the Piedmont and Coastal Plain of South Carolina.

\section{Sturm Equation}

The Sturm equation (Sturm, 1999; Richardson and Davis, 2001) for predicting clear-water abutment-scour depth was derived from dimensional analysis and laboratory data for compound channels. Laboratory data used in the derivation was for scour in non-cohesive sediments, and the measured abutment-scour depths reflected total scour at the abutment (local abutment scour and contraction scour). Sturm's analysis used an approach similar to Laursen (1963) in which abutment scour is assumed to be a function of contraction scour in the following relation:

$$
d_{s}=r d_{s c}
$$

where

$$
\begin{aligned}
& d_{s} \text { is the abutment-scour depth, in feet; } \\
& r \text { is some constant greater than one; and } \\
& d_{s c} \text { is the contraction-scour depth, in feet. }
\end{aligned}
$$

In the case of clear-water contraction scour, Laursen assumed that a bridge is analogous to a long contraction in which flow has become uniformly distributed. Contraction scour occurs when the flow velocity exceeds the critical velocity for the bed material. As scour lowers the bed, velocities diminish, and scour ceases when the flow velocity equals the critical velocity. Using a similar approach, Sturm (1999) developed the following equation for clear-water contraction scour that incorporated the effect of compound channels.

$$
\frac{d_{s c}}{y_{f 0}}+1=\left(\frac{q_{f 1}}{M V_{c} y_{f 0}}\right)^{\frac{6}{7}},
$$

where

$d_{s c}$ is the clear-water contraction-scour depth, in feet;

$y_{f 0}$ is the average undisturbed depth of flow on the flood plain at the approach, in feet; (The term "undisturbed" refers to flow conditions without the bridge.)

$q_{f 1}$ is the constricted unit-width flow rate on the flood plain, in cubic feet per second per unit width; (The term "constricted" refers to the flow conditions resulting from the constriction of flow forced by the bridge.)

$V$ is the critical velocity of the median bed material on the flood plain for the undisturbed flow depth, $y_{f o}$, in feet per second; and

$M$ is the flow distribution factor defined as

$$
\left(Q_{1 / 2 c h}+Q_{f p}-Q_{b f}\right) /\left(Q_{1 / 2 c h}+Q_{f p}\right),
$$

where

$Q_{1 / 2 c h}$ is half of the constricted flow in the main channel at the approach section (from the channel centerline to the channel bank), in cubic feet per second;

$Q_{f p}$ is the constricted flow on the left or right flood plain at the approach section, in cubic feet per second; and

$Q_{b f}$ is the constricted flood-plain flow blocked by the road embankment at the approach section, in cubic feet per second. 
Using the relation in equation 4 and realizing that the exponent in equation 5 is approximately 1 , Sturm proposed the following general equation for abutment scour in compound channels.

$$
\frac{d_{s}}{y_{f 0}}=C_{1}\left(\frac{q_{f 1}}{M V_{c} y_{f 0}}-C_{0}\right)
$$

where

$$
\begin{aligned}
& d_{s} \text { is the clear-water abutment-scour depth, in feet; } \\
& \text { (This value reflects total scour depth at the } \\
& \text { abutment.) } \\
& C_{1} \text { and } C_{0} \text { are coefficients to be determined by } \\
& \text { laboratory experiments; and all other variables } \\
& \text { are defined in equation } 5 \text {. }
\end{aligned}
$$

Using laboratory experiments, Sturm defined the coefficients $C_{1}$ and $C_{0}$ and proposed the following equation for estimating abutment-scour depth under clear-water scour conditions.

$$
\frac{d_{s}}{y_{f 0}}=8.14 K_{s t}\left(\frac{q_{f 1}}{M V_{c} y_{f 0}}-0.4\right) \text {, }
$$

where

$$
\begin{aligned}
& d_{s}, y_{f 0}, q_{f 1}, M \text {, and } V_{c} \text { are defined in equations } 5 \\
& \text { and } 6 \text {, and }
\end{aligned}
$$

$K_{s t}$ is Sturm's abutment shape correction factor that ranges from 0 to 1 . For vertical abutments with or without wingwalls, $K_{s t}$ is set to 1 . For spill-through abutments, the following equation is used.

$$
K_{s t}=1.52\left(X_{a}-0.67\right) /\left(X_{a}-0.40\right),
$$

where

$$
\begin{aligned}
X_{a}= & \frac{q_{f 1}}{M V_{c} y_{f 0}} ; \text { and } q_{f 1}, M, V_{c}, \text { and } y_{f 0} \text { are defined } \\
& \text { in equation } 5 .
\end{aligned}
$$

If $X_{a}$ is greater than or equal to 1.2 , then $K_{s t}$ is set to 1 . If $X_{a}$ is less than or equal to 0.67 , then $K_{s t}$ is set to 0 . For the laboratory data, equation 7 has a standard deviation of 0.86 and a standard error of estimate of 0.68 for the dimensionless ratio of $d_{s} / y_{f Q}$ (Sturm, 1999). To account for this error, Richardson and Davis (2001) include a safety factor of 1 in the equation, making the final form of the equation as follows:

$$
\frac{d_{s}}{y_{f 0}}=8.14 K_{s t}\left(\frac{q_{f 1}}{M V_{c} y_{f 0}}-0.4\right)+1,
$$

where all variables are defined in equations 5, 6, and 7.

Based on laboratory data from various investigations of abutment scour, Melville (1992) suggests that the dimensionless scour ratio, $d_{s} / y_{f 0}$, should be limited to a maximum value of 10. Sturm's (1999) laboratory data for compound channels supports this conclusion. Therefore, in HEC-18, Richardson and Davis (2001) recommend that if the dimensionless scour ratio in equation 9 exceeds 10 , then the value should be truncated to 10 .

When applying the Sturm equation (Richardson and Davis, 2001) to the South Carolina data, the flows $Q_{1 / 2 c h}, Q_{f p}$, and $Q_{b f}$ must be estimated to compute the flow distribution factor, $M$. Slightly different approaches for defining these flows (and hydraulic variables associated with the flows) must be used at sites with a well-defined low-flow channel and at swampy sites with no well-defined channel. For sites with well-defined low-flow channels (typically found in the Piedmont), the flows $Q_{1 / 2 c h}, Q_{f p}$, and $Q_{b f}$ generally were estimated by prorating flow by conveyance (for constricted conditions) using the respective parts of the approach cross section defined in figure 10. $Q_{1 / 2}$ ch was computed as the total flow in the main channel divided in half. $Q_{f p}$ and $Q_{b f}$ represent the approach flows for the areas as defined in figure 10 , with $Q_{b f}$ being identical to the blocked flow $\left(Q_{e}\right)$ defined for the original Froehlich equation (Richardson and Davis, 2001). For swampy sites with no well-defined low-flow channel (typically found in the Coastal Plain), the flow $Q_{1 / 2}$ was computed as the unobstructed flow at the approach cross section (fig. 11) divided in half. The unobstructed flow generally was determined by subtracting the flow blocked by the left and right road embankments from the total flow at the approach cross section. The flood-plain flow (fig. 11), $Q_{f p}$, was assumed equal to the flow blocked by the road embankment, $Q_{b f}$. Once the flows $Q_{1 / 2 c h}, Q_{f p}$, and $Q_{b f}$ were estimated for the given channel conditions, other equation variables were determined as follows. 


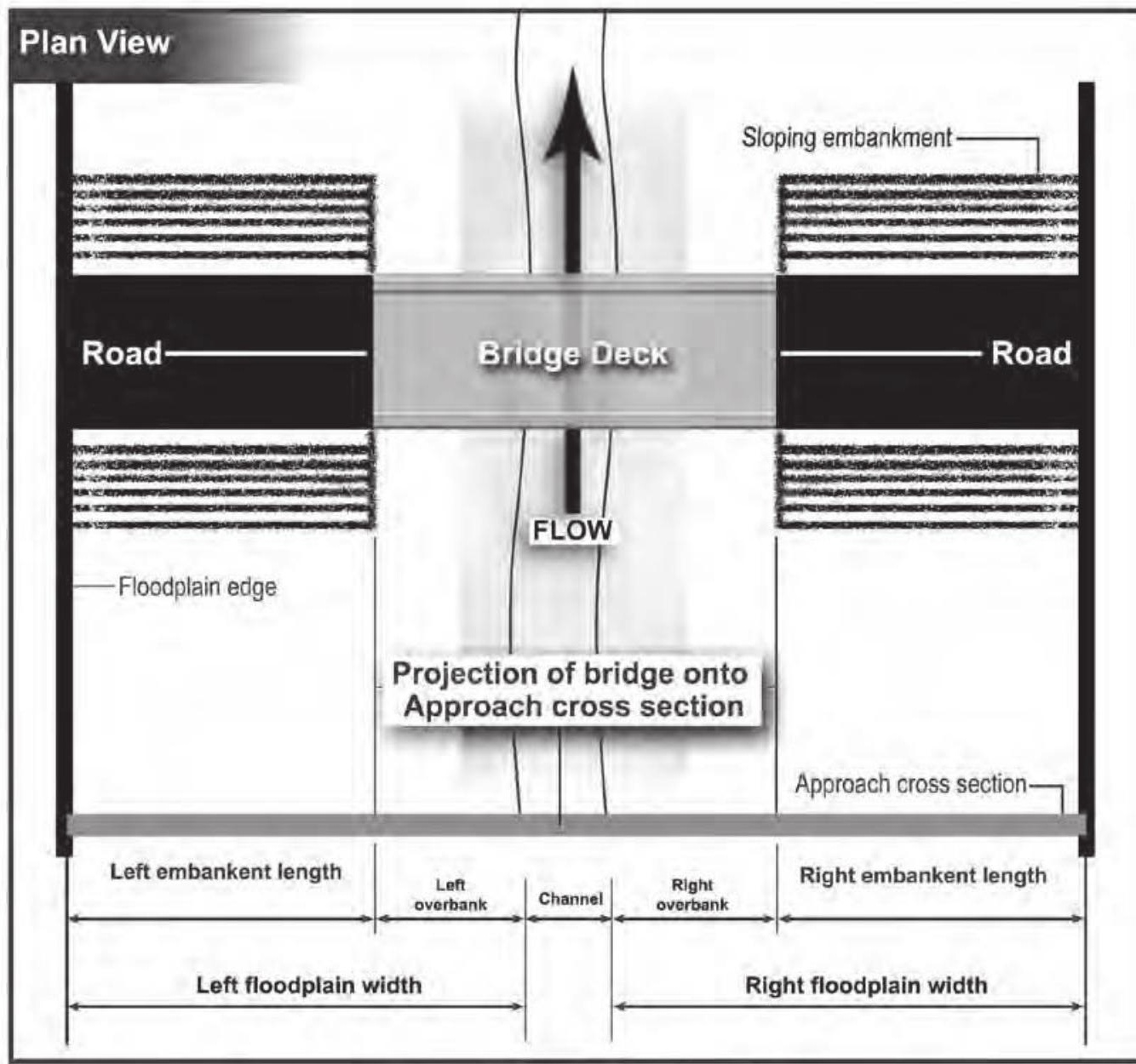

Profile of Approach Cross Section

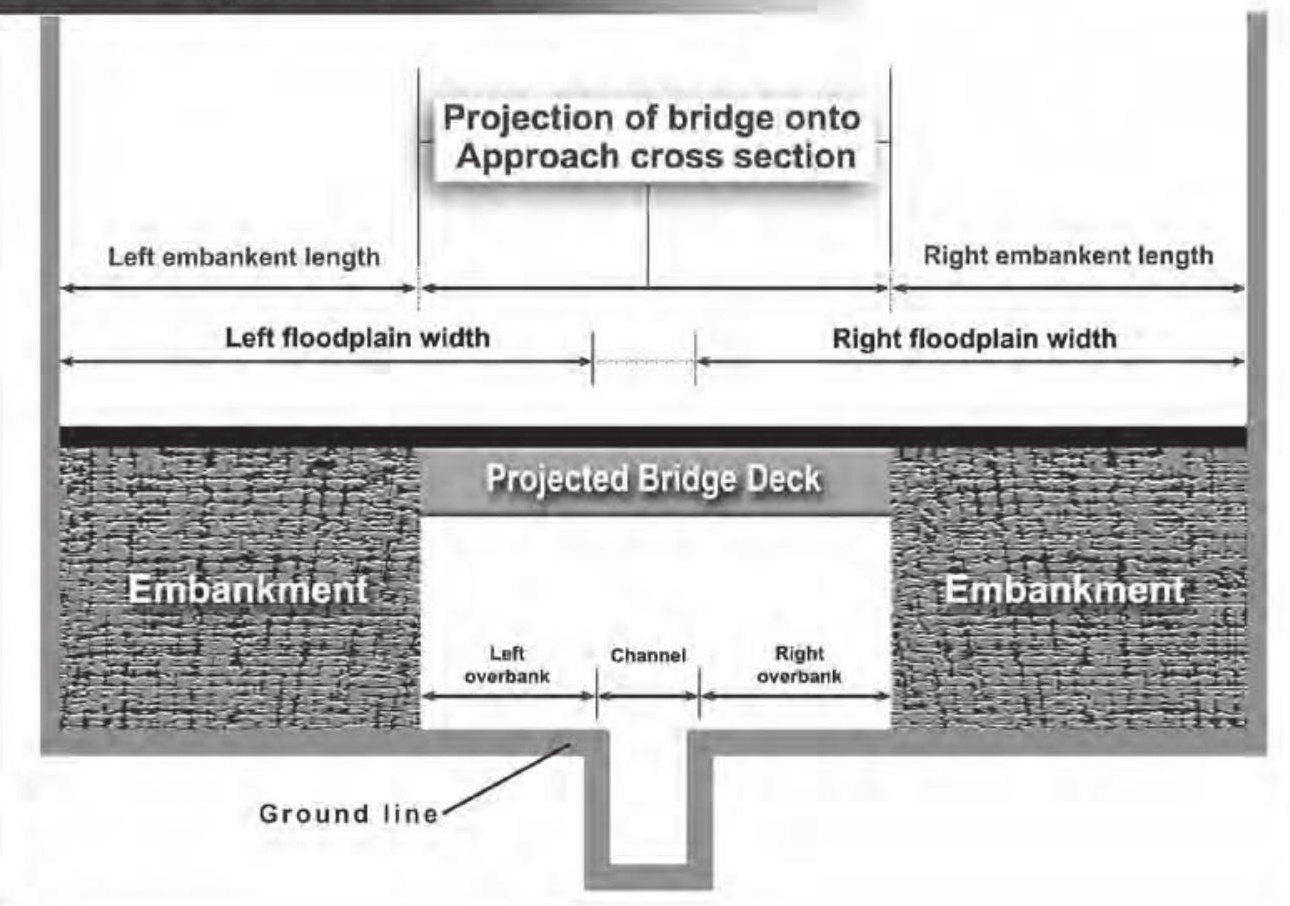

Figure 10. Approach cross section with a well-defined low-flow channel, identifying areas used to determine hydraulic properties. 


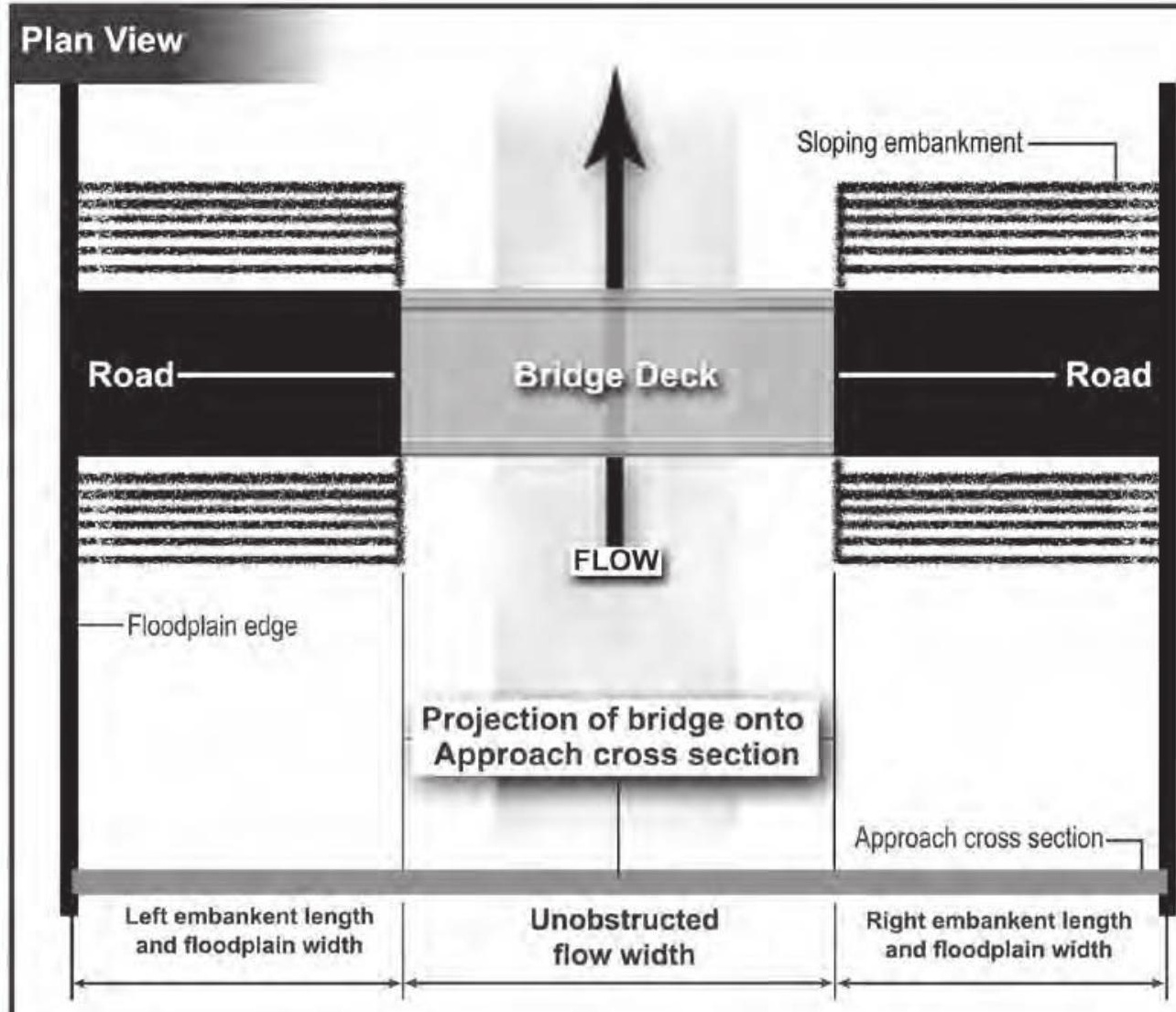

\section{Profile of Approach Cross Section}

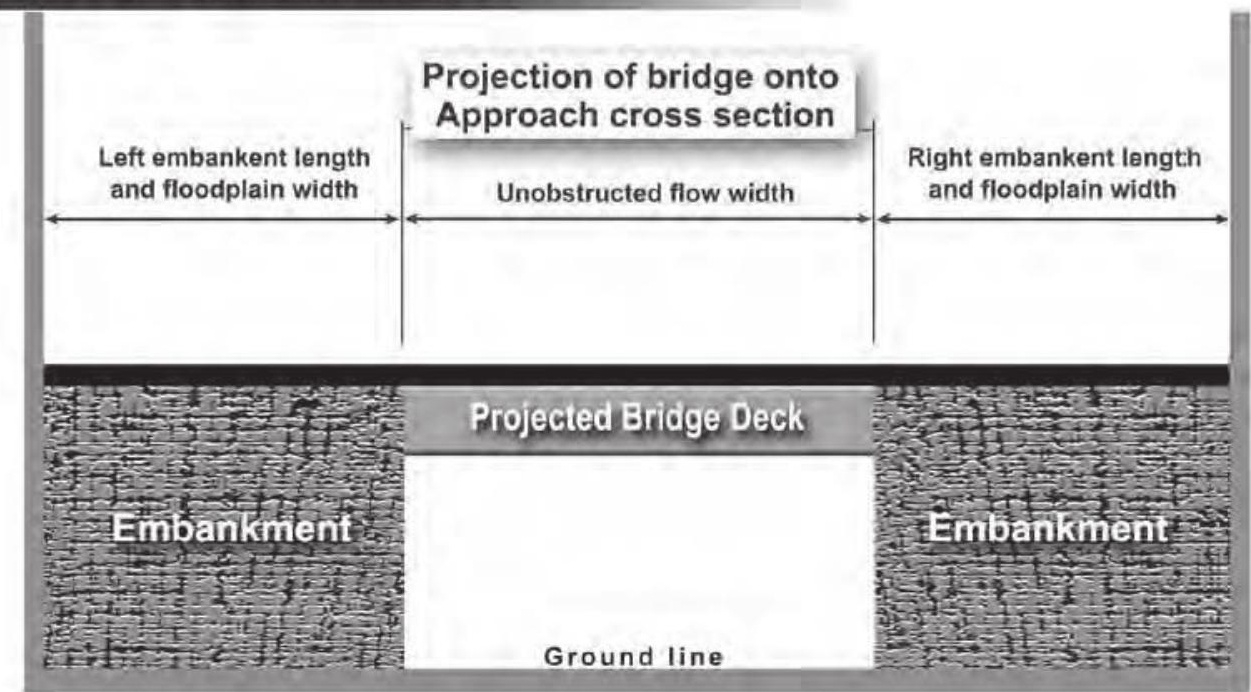

Figure 11. Approach cross section for swampy site with no well-defined low-flow channel, identifying areas used to determine hydraulic properties. 
To compute the constricted unit-width flow rate on the flood plain, $q_{f l}$, the $Q_{b f}$ was divided by the embankment length blocking flow (the same as $L$ in the original Froehlich equation (Richardson and Davis, 2001)). The hydraulic data readily accessible for the South Carolina field data represent flow for constricted conditions (bridge in place) and not undisturbed conditions. Therefore, the average, undisturbed flood-plain flow depth, $y_{f o}$, was estimated in the following manner. The average, constricted flood-plain flow depth (identical to $y_{a}$ in the original Froehlich equation) was computed and then adjusted by subtracting the backwater created by the bridge to determine the average undisturbed flood-plain flow depth.

All bridge sites in the South Carolina database were classified as setback abutments. Based on this classification, the critical velocity of the median bed material on the flood plain, $V_{c}$, was computed for the undisturbed flow depth, $y_{f 0}$, by using the critical velocity equation in HEC-18 (Richardson and Davis, 2001) and defined below.

$$
V_{c}=11.17 y^{\frac{1}{6}} D^{\frac{1}{3}},
$$

where

$V_{c}$ is the critical velocity above which bed material size D and smaller will be transported, in feet per second; $y$ is the average depth of flow, in feet (when applied to the Sturm equation at setback abutments, $\mathrm{y}$ is equal to $y_{f 0}$ ); and

$D$ is the grain size of interest, in feet.

Once the above variables were determined, all other variables were calculated and applied to equation 9. If the dimensionless scour depth, $d_{s} / y_{f 0}$, exceeded a value of 10 , then the value was truncated to 10 . Because all of the South Carolina abutment-scour data were classified as clear-water scour, only Sturm's clear-water abutment-scour equation was used. Abutment-scour computations with the Sturm equation (Richardson and Davis, 2001) were made with and without the safety factor.

Predicted abutment-scour depths computed with the Sturm equation (Richardson and Davis, 2001) were compared with abutment-scour depths observed in the Piedmont and Coastal Plain of South Carolina (fig. 12). Predicted scour in figure 12 was computed with the 100-year flow and includes the safety factor. Additional figures and computational data for the 100-year flow and maximum historic flow are included in the digital spreadsheets in Appendix B.

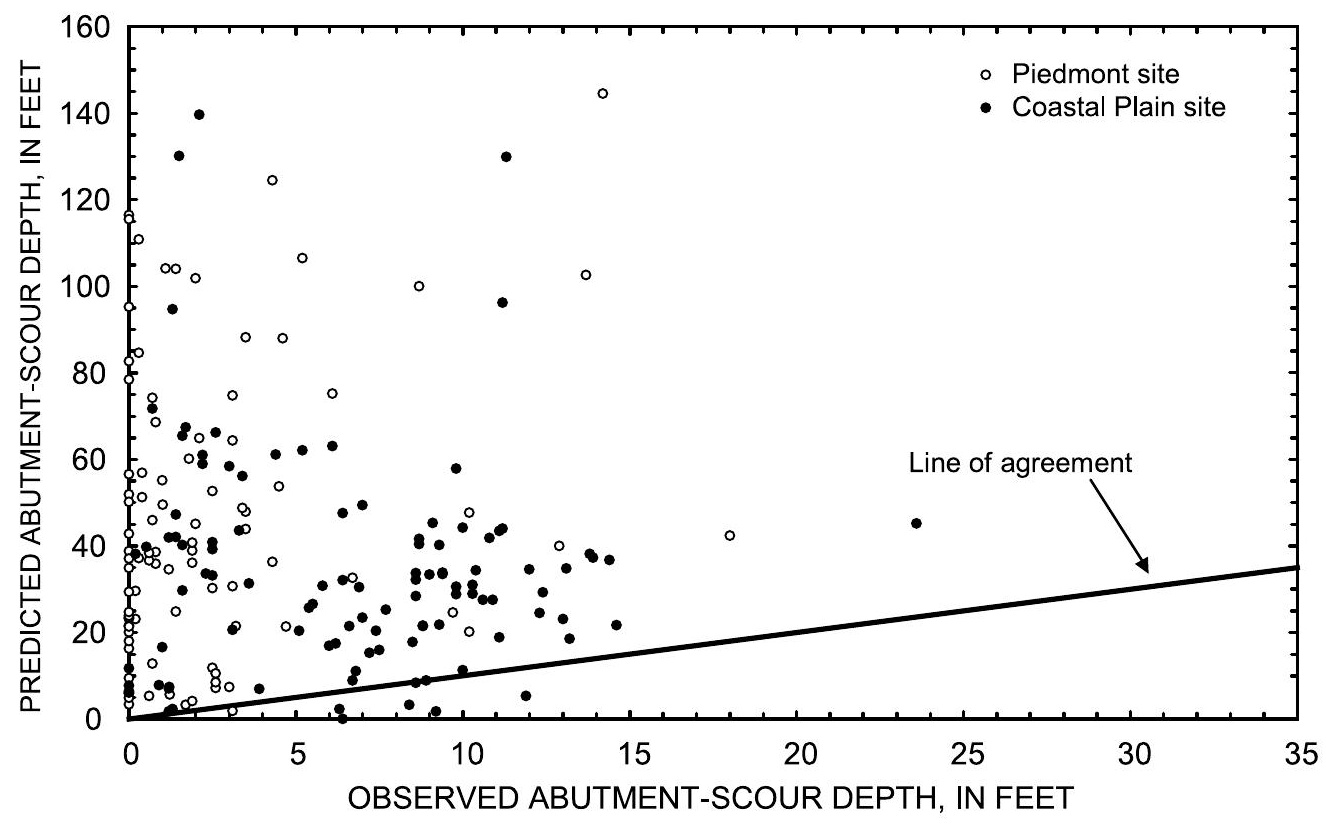

Figure 12. Field observations of abutment-scour depth and predicted abutment-scour depth for the 100-year flow, computed with the Sturm equation (Richardson and Davis, 2001) with the factor of safety, for selected sites in the Piedmont and Coastal Plain of South Carolina. 


\section{Maryland Equation}

The Maryland equation (Chang and Davis, 1999; Richardson and Davis, 2001; Maryland State Highway Administration, 2005) was derived using an approach similar to Laursen's (1963) estimate of abutment scour at long contractions. As discussed under the Sturm equation, Laursen assumed that local abutment scour is a function of contraction scour (eq. 4). To estimate the depth of clear-water contraction scour, Chang and Davis (1999) proposed the following equation based on work by Neill (1973):

$$
d=\frac{q}{V_{c}}
$$

where

$d$ is the total flow depth in the contraction, including the clear-water scour depth, in feet;

$V_{c}$ is the critical flow velocity for the median grain size of the bed material, in feet per second; and

$q$ is the unit-width flow in the contraction, in cubic feet per second per unit width, and is defined as:

$$
q=V y
$$

where

$V$ is the average velocity in the contraction prior to scour, in feet per second; and

$y$ is the average flow depth in the contraction prior to scour, in feet.

The clear-water contraction-scour depth is determined by the following equation,

$$
d_{s c}=d-y
$$

where

$$
\begin{aligned}
& d_{s c} \text { is the contraction-scour depth, in feet; and } \\
& d \text { and } y \text { are defined in equation } 11 .
\end{aligned}
$$

Various methods can be used to estimate the critical velocity, $V_{c}$. In HEC-18, Richardson and Davis (2001) suggest using Laursen's (1963) critical velocity relation as defined in equation 10. However, Chang and Davis (1999) recommend using a modified version of the competent velocity graph presented in Neill (1973). (Neill's competent velocity graph was modified by extrapolating the curves for grain sizes less than $0.3 \mathrm{~mm}$.) Neill's graph provides similar values to Laursen's critical velocity equation for gravel grain sizes (approximately $20 \mathrm{~mm}$ and greater), but higher critical velocity estimates for finer sediments. In the silt/clay range (0.062 $\mathrm{mm}$ and smaller), where soils commonly are cohesive, the larger estimates of critical velocity from Neill's modified graph are perhaps more reasonable than those from the Laursen (1963) equation. Neill (1973) also provided a table of competent velocities for cohesive soils, and guidance for applying these values has been included in later versions of the Users Manual for the Maryland Equation/ABSCOUR Program.

Chang and Davis (1999) converted Neill's modified competent velocity graph into a set of equations and combined these equations with equation 11 to form the following set of equations for predicting total flow depth, including the clear-water contraction-scour depth, for various ranges of bed materials:

$$
\begin{aligned}
D_{50} \geq 0.1, d & =\left[q /\left(11.5 D_{50}{ }^{0.33}\right)\right]^{0.86} \\
0.1>D_{50}>0.001, d & =\left[q /\left(11.5 D_{50}{ }^{0.35}\right)\right]^{x} \\
D_{50} \leq 0.001, d & =\left[q /\left(2.84 D_{50}{ }^{0.15}\right)\right]^{0.67}
\end{aligned}
$$

where

$$
\begin{aligned}
& D_{50} \text { is the median grain size of the bed mate- } \\
& \text { rial, in feet; }
\end{aligned}
$$$$
x=\frac{1}{\left(1+\frac{0.123}{D_{50} 0.2}\right)} ; \text { and }
$$

$d$ and $q$ are defined in equation 11 .

Chang and Davis (1999) specified methods for computing the unit-width flow, $q$, in equation 13 based on the distance that the bridge abutment is set back from the main channel. (See Maryland State Highway Administration (2005) for details on computing the unit-width flow.)

Using Laursen's (1963) concept of clear-water abutment scour (eq. 4), Chang and Davis (1999) proposed the following equation for predicting the total flow depth at an abutment, including the total abutment-scour depth:

$$
d_{a b}=\left(k_{v}\right)^{0.857} k_{f} k_{p} d
$$

where

$d_{a b}$ is the total flow depth at the abutment, including the total clear-water abutment-scour depth, in feet;

$k_{v}$ is a coefficient to account for the increase in flow velocity at the abutment that ranges from 1.0 to 1.8 and is equal to $0.8\left(q_{1} / q_{2}\right)^{1.5}+1$, where $q_{1}$ and $q_{2}$ are the unit-width flows for the approach and contracted sections, respectively;

$k_{f}$ is a coefficient to account for turbulence at the abutment that ranges from 1.00 to 4.0 and is equal to $0.13+5.8 F_{1}$,

where

$F_{1}$ is the Froude number for the approach flow velocity, defined as:

$$
F_{1}=V_{e} /\left(g y_{a}\right)^{0.5}
$$

where

$$
\begin{aligned}
& g \text { is the acceleration due to gravity, in feet } \\
& \text { per square second; } \\
& y_{a} \text { is defined in equation } 1 \text {; and }
\end{aligned}
$$


$V_{e}$ is the average flow velocity upstream from the embankment, in feet per second, and is defined as:

$$
\mathrm{V}_{\mathrm{e}}=\mathrm{Q}_{\mathrm{e}} / \mathrm{A}_{\mathrm{e}},
$$

where

$Q_{e}$ is the flow obstructed by the embankment, in cubic feet per second; and

$A_{e}$ is the flow area obstructed by the embankment, in square feet;

$k_{p}$ is a coefficient to account for the effect of pressure flow and ranges from 1.0 to 1.15 and is equal to $0.66 F_{1}^{-0.45}$, where $F_{1}$ is defined above; and

$d$ is defined in equation 11 .

When $d_{a b}$ has been computed, the clear-water abutment-scour depth $\left(d_{s}\right)$ can be obtained by modifying equation 12 to the following:

$$
d_{s}=k_{t} k_{e}\left(d_{a b}-y\right),
$$

where

$$
\begin{aligned}
& d_{s} \text { is the total clear-water abutment-scour depth, } \\
& \text { in feet (local abutment scour and contraction }
\end{aligned}
$$
scour);

$k_{t}$ is a coefficient for abutment shape;

$k_{e}$ is a coefficient for abutment skew; and

$d_{a b}$ and $y$ are defined in equations 14 and 11, respectively. (Refer to Maryland State Highway Administration (2006) for the equations of these coefficients.)

Chang and Davis (1999) tested their method for computing abutment scour by using laboratory data and found the equation to predict within \pm 20 percent. Based on this finding, Chang and Davis originally recommended that a safety factor between 1.2 and 1.4 be applied to the computed scour value, and later program updates provide guidance in selecting the safety factor. (For details on the derivation of the Maryland equation, see Maryland State Highway Administration (2005).)

When applying the Maryland equation (Richardson and Davis, 2001) to the South Carolina data, the computer program ABSCOUR (Maryland State Highway Administra- tion, 2005, 2006) was used. This program incorporates minor modifications to the Maryland equation and, therefore, may give slightly different values from the version of the equation presented in HEC-18 (Richardson and Davis, 2001). In general, this program requires basic hydraulic variables at the bridge and approach cross sections as input data, and these data can be readily obtained from a one-dimensional flow model. The input data include hydraulic variables on the left and right flood plain and in the main channel. For swampy sites where the main channel is poorly defined, the entire flood plain was assumed to represent the approach channel with no left or right overbank flow (fig. 13), and the entire opening at the bridge was assumed to represent the channel at the bridge with no left or right overbank flow. (This procedure was recommended by Stanley Davis of the Maryland State Highway Administration, oral commun., December 2003. Mr. Davis also noted that the application of the Maryland equation was developed for relatively small rivers with well-defined channels and that the wide, swampy flood plains, like those in the Coastal Plain of South Carolina, were likely beyond the reasonable application of the equation. This may explain, in part, the poor performance of the equation at the Coastal Plain sites.)

Because all of the South Carolina abutment-scour data were classified as clear-water scour, only the clear-water abutment-scour equation was used in the ABSCOUR program (Maryland State Highway Administration, 2006). For computing the critical velocity of the bed material, ABSCOUR allows the user to select Neill's (1973) modified competent velocity or Laursen's (1963) critical velocity. Abutment-scour computations were made using both methods for estimating critical velocity. All abutment-scour computations were initially made without a safety factor; however, a safety factor of 1.3 was included in the spreadsheets for the computational options described above.

Predicted abutment-scour depths for the Maryland equation (Richardson and Davis, 2001), computed with the ABSCOUR (Maryland State Highway Administration, 2006) program, were compared with abutment-scour depths observed in the Piedmont and Coastal Plain of South Carolina (fig. 14). Predicted scour in figure 14 was computed with the 100-year flow and includes the safety factor. The ABSCOUR program uses a minimum default value of 5 feet of scour. Additional figures and computational data for the 100-year flow and maximum historic flow are included in the digital spreadsheets in Appendix B. 


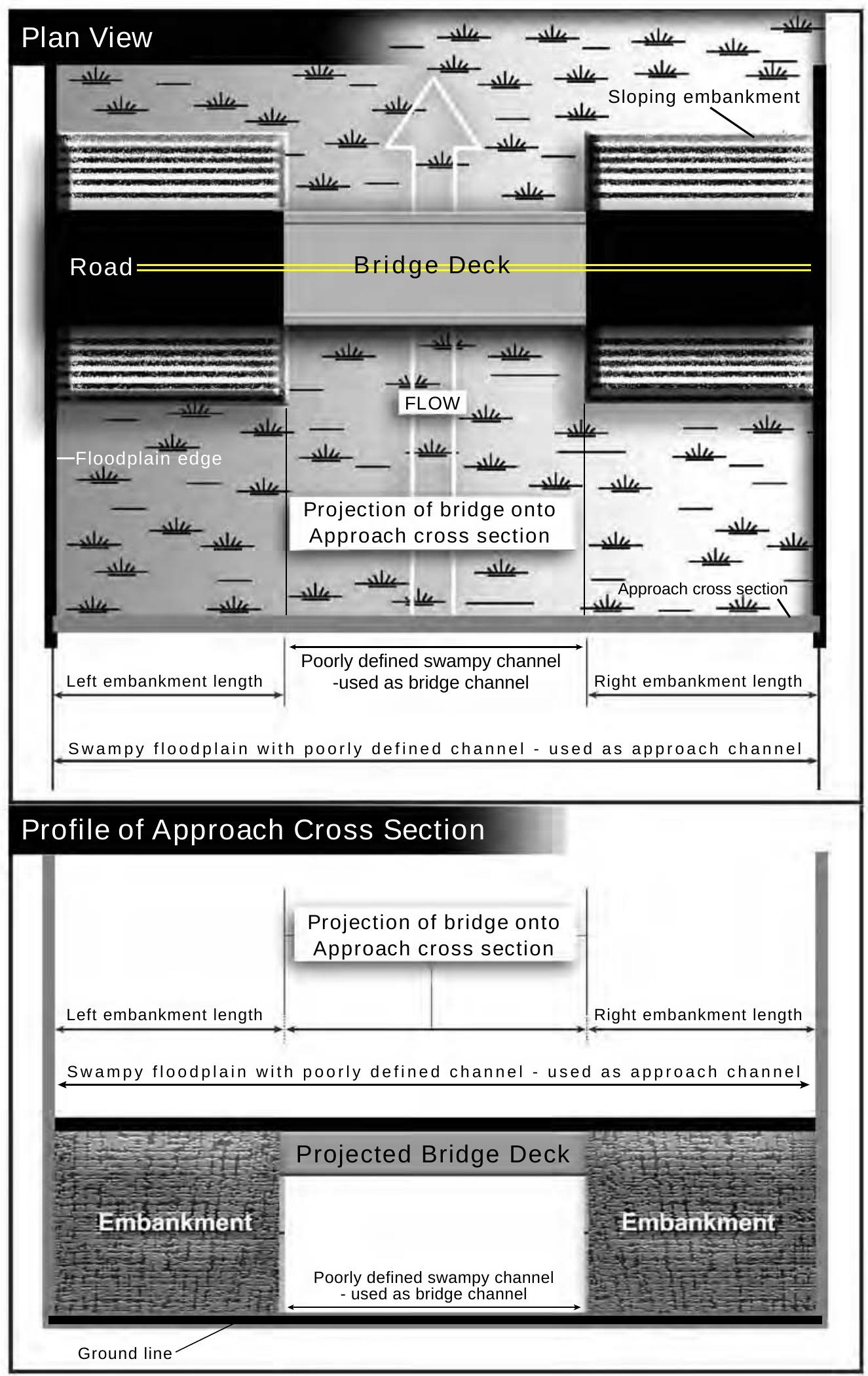

Figure 13. Approach cross section for swampy site with no well-defined low-flow channel, identifying the channel used in applying the Maryland equation. 


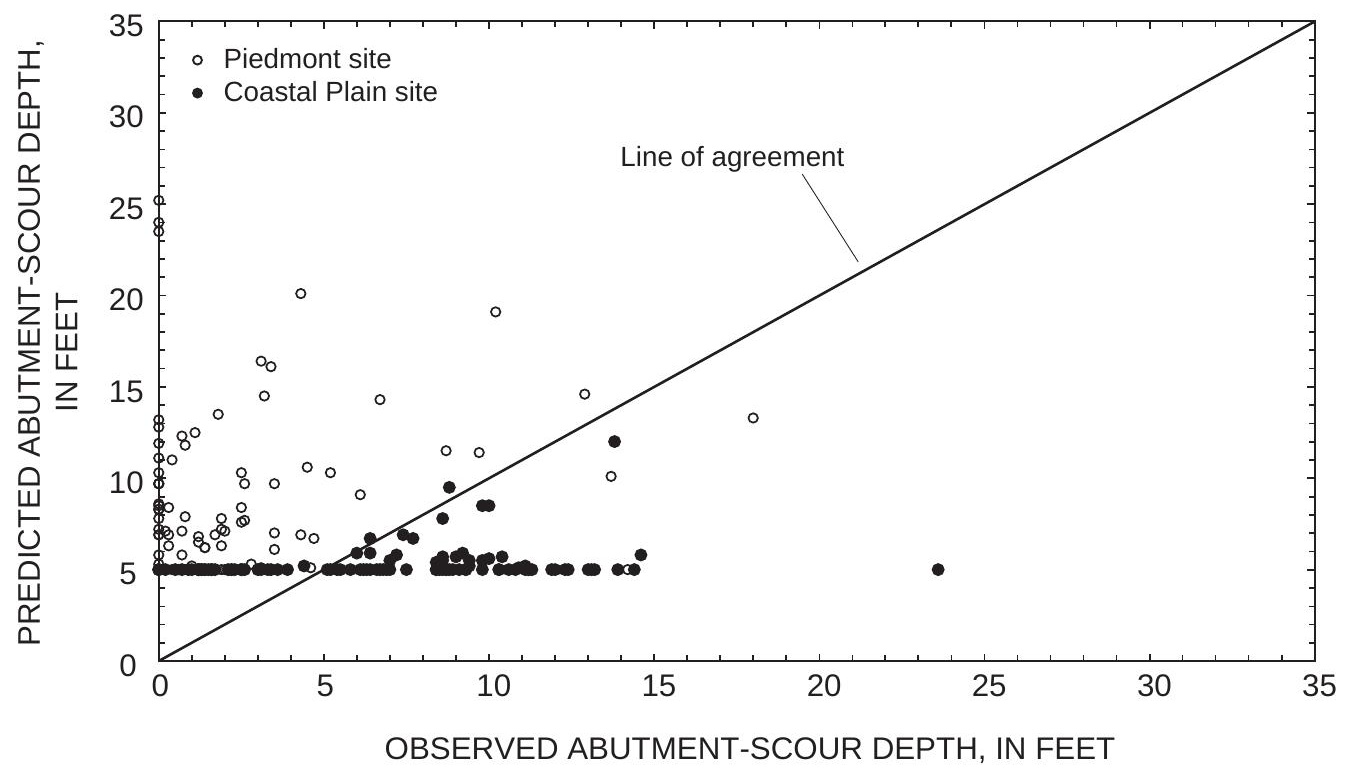

Figure 14. Field observations of abutment-scour depth and predicted abutment-scour depth for the 100-year flow, computed with the Maryland equation (Richardson and Davis, 2001) with the factor of safety, for selected sites in the Piedmont and Coastal Plain of South Carolina.

\section{HIRE Equation}

The HIRE equation (Richardson and others, 1990; Richardson and Davis, 2001) was developed from the U.S. Army Corps of Engineers' field data of scour at the end of spurs in the Mississippi River. The equation, defined below, is applicable only when the ratio of embankment length and flow depth at the abutment is greater than 25 :

$$
\frac{y_{s}}{y_{1}}=4\left[\frac{K_{1}}{0.55}\right] F^{0.33},
$$

where

$y_{s}$ is the abutment-scour depth, in feet;

$y_{1}$ is the depth of flow upstream and adjacent to the abutment, in feet;

$K_{1}$ is the dimensionless correction factor for abutment shape;

$\mathrm{Fr}$ is the Froude number of the flow upstream and adjacent to the abutment, and is defined as:

$$
F r=V_{e} /\left(g y_{1}\right)^{0.5},
$$

where

$V_{e}$ is the flow velocity upstream and adjacent to the abutment, in feet per second; and

$g$ is the acceleration due to gravity, in feet per square second.
When applying the HIRE equation (Richardson and Davis, 2001) to the South Carolina data, equation variables were determined in the following manner. The velocity adjacent to the abutment was determined by using the WSPRO stream-tube algorithm at the bridge cross section. The average velocity of the tube containing the abutment toe was chosen to represent $V_{e}$. The depth of flow at the abutment, $y_{1}$, was determined by subtracting the ground elevation at the abutment toe from the water-surface elevation at the bridge. Although the HIRE equation is limited to sites with embankment length to flow depth ratios greater than 25 , computations were made at all sites in the South Carolina database regardless of the ratio.

Predicted abutment-scour depths computed with the HIRE equation (Richardson and Davis, 2001) were compared with abutment-scour depths observed in the Piedmont and Coastal Plain of South Carolina (fig. 15). Predicted scour in figure 15 was computed with the 100-year flow. Additional figures and computational data for the 100-year flow and maximum historic flow are included in the digital spreadsheets in Appendix B. 


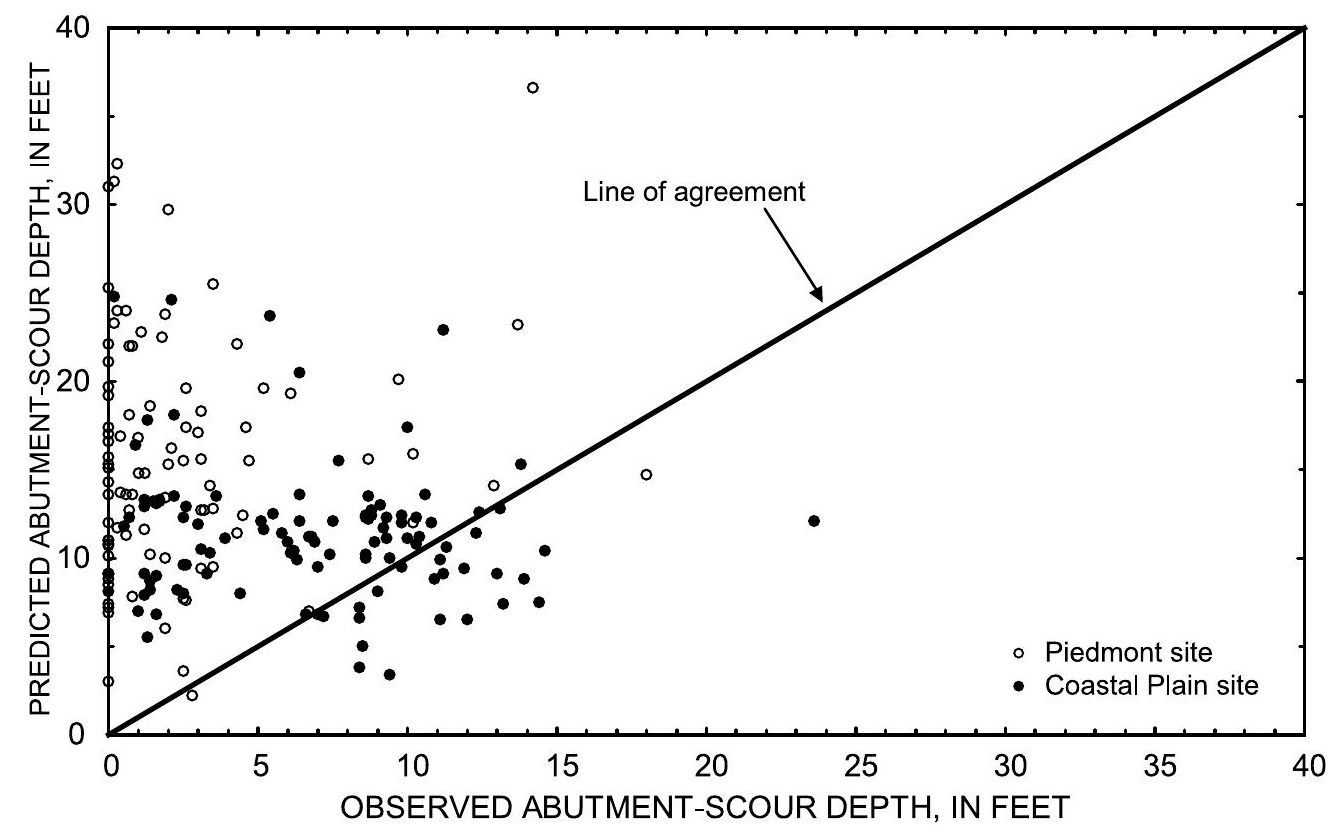

Figure 15. Field observations of abutment-scour depth and predicted abutment-scour depth for the 100-year flow, computed with the HIRE equation (Richardson and David, 2001) for selected sites in the Piedmont and Coastal Plain of South Carolina.

\section{Young Equation}

Using Shield's number, Manning's equation, and the principle of continuity in a dimensional analysis, Young and others (K. Young, K. Saffarinia, and J.S. Jones, Federal Highway Administration, unpub. data, 2002) developed the following dimensionless equation for predicting contraction scour:

$$
\frac{x}{y}=\left[\frac{\left(n V_{R}\right)^{2}}{S(S G-1) D_{50} \sqrt[3]{y}}\right]^{\frac{3}{7}}
$$

where

$x$ is the total flow depth at the abutment, including the depth of scour, in meters;

$y$ is the depth of flow over the flood plain prior to scour, in meters;

$n$ is Manning's coefficient of roughness, defined as $n=0.0185(y)^{1 / 6}$ for sand (Blodgett, 1986);

$S$ is the dimensionless Shields number (ratio of inertial to gravitational force) and is equal to 0.047 for sand motion;

$S G$ is the specific gravity and is equal to 2.65 for sand;

$D_{50}$ is the mean sediment size, in meters; and

$V_{R}$ is the resultant velocity at an abutment due to flow contraction, in meters per second.
Through analytical methods and the use of laboratory data, the relation for the resultant velocity, $V_{R}$, was determined to be

$$
V_{R}=\left(\left(\frac{A}{A-a}\right)^{2}+\left(\frac{a}{0.43 A}\right)^{2}\right)^{\frac{1}{2}} \bar{V}
$$

where
$A$ is the cross-section area from the flood-plain edge to the center of the channel, in square meters;
$\bar{V}$ is the average flow velocity over area $\mathrm{A}$, in meters per second; and
$a$ is the flow area blocked by the embankment, in square meters.

As with the Sturm (Richardson and Davis, 2001) and Maryland (Richardson and Davis, 2001) equations, it was assumed that local scour at an abutment is a function of contraction scour, and that an adjustment factor, $K$, could be applied to the contraction-scour depth of equation 17 to determine the abutment-scour depth. Using a multiple regression analysis for 239 laboratory observations of contraction 
and abutment scour in non-cohesive sediments, the following data adjustment factor was determined:

$$
K=1+1.5393\left(\frac{a}{y^{2}}\right)^{0.3798}
$$

where

$$
\begin{aligned}
& K \text { is the adjustment factor and is equal to the } \\
& \text { ratio of total scour at the abutment to } \\
& \text { contraction scour }(K \text { is truncated to } 10 \\
& \text { when it exceeds } 10) \text {; and } \\
& a \text { and } y \text { are defined in equations } 18 \text { and } 17 \text {, } \\
& \text { respectively. }
\end{aligned}
$$

Using this adjustment factor with the previously defined constants for specific gravity, $S G$, and Shield's number, $S$, equation 17 can be modified to the following form:

$$
\frac{x}{y}=3 K\left[\frac{\left(n V_{R}\right)^{2}}{D_{50} \sqrt[3]{y}}\right]^{\frac{3}{7}},
$$

where all variables are defined in equations 17 and 19.

Once the dimensionless variable, $x / y$, has been determined, correction coefficients for abutment shape and skew are applied. These correction coefficients were not specified in the preliminary documentation of equation 20 and were assumed in this study to be the same coefficients used in the original Froehlich equation (Richardson and Davis, 2001). The total abutment-scour depth (local abutment scour and contraction scour), $d_{s}$, was determined by multiplying the dimensionless variable, $x / y$, by $y$ and then subtracting $y$. Equation 20 was tested with 239 laboratory observations of abutment scour obtained from rectangular and composite channels and, excluding 5 outliers, arrived at a coefficient of determination, $R^{2}$, equal to 0.87 .

When applying equation 20 to the South Carolina data, the area $A$ (fig. 16) and the flow through that area must be determined in order to estimate the average velocity, $\bar{V}$. Slightly different approaches for defining these values must be used for sites with a well-defined low-flow channel and for swampy sites with no well-defined channel. For sites with well-defined low-flow channels, typically found in the Piedmont (fig. 10), the flow area, $A$, was determined by taking half of the flow area in the main channel at the approach cross section and adding it to the flow area for the flood plain of interest. To estimate the flow through area $A$, half of the flow in the approach main channel was added to the flow of the flood plain of interest. Flows for the channel and flood-plain subsections were determined by prorating the total flow by conveyance. For swampy sites with no well-defined channels, typically found in the Coastal Plain (fig. 11), the flow area, $A$, was determined by taking half of the unobstructed flow area at the approach cross section and adding it to the flow area for the flood plain of interest. To estimate the flow through area $A$, half of the unobstructed flow at the approach cross section was added to the flow of the flood plain of interest. Flows for the unobstructed flow area and flood-plain subsections were determined by prorating the total flow by conveyance. Once these variables were estimated for the given channel conditions, other equation variables were determined as follows.

The average velocity, $\bar{V}$, was determined by dividing the flow through area $A$ by that same area. The area blocked by the embankment, $a$, is representative of the flow area across the embankment top width as shown in figure 6 and is the same as the blocked area used in the original Froehlich equation (Richardson and Davis, 2001). Figure 16 indicates that the depth of flow over the flood plain prior to scour, $y$, should represent the flow depth near the abutment toe. Therefore, the average flow depth in the bridge overbank (excluding any main channel) was used to represent $y$ and typically was determined by dividing the bridge overbank-flow area by the corresponding overbank top width. Once the above variables were determined, all other variables were calculated and applied to equation 20 . The computations for equation 20 were made initially in metric units and then converted to English units. The digital spreadsheets in Appendix B present the variables used in the computation and the equation results in English units.

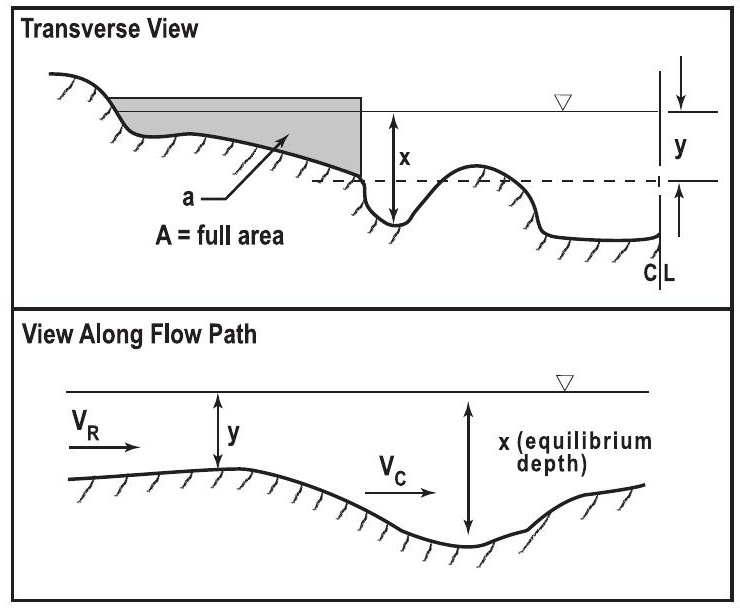

Figure 16. Definition of scour hole velocities, depths, and areas for equation 20 (K. Young, K. Saffarinia, and J.S. Jones, Federal Highway Administration, unpub. data, 2002). 
Predicted abutment-scour depths computed using equation 20 were compared with the abutment-scour depths observed in the Piedmont and Coastal Plain of South Carolina (fig. 17). Predicted scour in figure 17 was computed with the 100-year flow. Additional figures and computational data for the 100-year flow and maximum historic flow are included in the digital spreadsheets in Appendix B.

\section{Development of Two-Dimensional Flow Models}

Two-dimensional flow models were developed for five South Carolina bridge sites (table 2) by using the Surface-Water Modeling System (SMS; Brigham Young University, 2000). The models were developed in anticipation of future research in which predicted abutment scour computed with two-dimensional hydraulic variables would be compared with predicted abutment scour computed with one-dimensional hydraulic variables. A general description of site characteristics and model development follows. The input data for each of the five models and the output from preliminary runs were transmitted to the FHWA but are not analyzed or presented in this report.

The sites in table 2 were selected for analysis with a two-dimensional model because (1) contractions of flow were

fairly large, (2) flood-plain widths were fairly uniform, and (3) observed abutment scour was well defined and(or) relatively deep. To gain an understanding of each site, selected basin, hydraulic, and field characteristics were considered (tables 3, 4). Hydraulic variables listed in these tables were determined with the WSPRO model (Shearman, 1990) using the 100-year flow and should be viewed as estimated values rather than measured data. In addition to tabular data, figures 18 through 22 present topographic contour plots of the observed abutment scour at each site. Additional information for these sites can be obtained from the SCBSD (Benedict, 2003) and from the data spreadsheets in Appendix C.

Table 2. Sites for which two-dimensional flow models were developed.

[SCDOT, South Carolina Department of Transportation; S.C., South Carolina route; S, secondary road; U.S., United States highway]

\begin{tabular}{lllcr}
\multicolumn{1}{c}{ County } & Road & \multicolumn{1}{c}{ Stream } & $\begin{array}{c}\text { SCD0T } \\
\text { structure } \\
\text { number }\end{array}$ & $\begin{array}{c}\text { Reference } \\
\text { number } \\
\text { (fig. 1 } \\
\text { and } \\
\text { Appendix A) }\end{array}$ \\
\hline Abbeville & S.C. 201 & Little River & 014020100300 & 1 \\
Hampton & S.C. 363 & Coosawhatchie River & 254036300100 & 68 \\
Jasper & S-87 & Coosawhatchie River & 277008700100 & 83 \\
Newberry & U.S. 176 & Indian Creek & 362017600400 & 106 \\
Newberry & S-81 & Enoree River & 367008100200 & 112 \\
\hline
\end{tabular}


Table 3. Selected basin characteristics for sites with two-dimensional flow models.

[S.C., South Carolina route; S, secondary road; U.S., United States highway]

\begin{tabular}{|c|c|c|c|c|c|c|c|}
\hline County & Road & $\begin{array}{c}\text { Stream } \\
\text { (reference number } \\
\text { in fig. } 1 \text { and } \\
\text { Appendix A) }\end{array}$ & $\begin{array}{l}\text { Slope of } \\
\text { streambed } \\
\text { (feet per } \\
\text { foot) }\end{array}$ & $\begin{array}{l}\text { Drainage } \\
\text { area } \\
\text { (square } \\
\text { miles) }\end{array}$ & $\begin{array}{c}\text { Physiographic } \\
\text { province }\end{array}$ & $\begin{array}{c}\text { Bridge } \\
\text { length } \\
\text { (feet) }\end{array}$ & $\begin{array}{c}{ }^{a} \text { Geometric } \\
\text { contraction } \\
\text { ratio }\end{array}$ \\
\hline Abbeville & S.C. 201 & Little River (1) & 0.00120 & 75 & Piedmont & 225 & 0.84 \\
\hline Hampton & S.C. 363 & Coosawhatchie River (68) & .00060 & 124 & Coastal Plain & 300 & .83 \\
\hline Jasper & $\mathrm{S}-87$ & Coosawhatchie River (83) & .00040 & 382 & Coastal Plain & 570 & .84 \\
\hline Newberry & U.S. 176 & Indian Creek (106) & .00110 & 87 & Piedmont & 400 & .82 \\
\hline Newberry & $\mathrm{S}-81$ & Enoree River (112) & .00050 & 677 & Piedmont & 330 & .67 \\
\hline
\end{tabular}

${ }^{\mathrm{a}}$ Determined from the Water-Surface Profile (WSPRO) model (Shearman, 1990) with the 100-year flow.

Table 4. Selected abutment data for sites with two-dimensional flow models.

[S.C., South Carolina route; S, secondary road; U.S., United States highway]

\begin{tabular}{|c|c|c|c|c|c|c|c|}
\hline County & Road & $\begin{array}{l}\text { Stream } \\
\text { (reference number } \\
\text { in fig. } 1 \text { and } \\
\text { Appendix A) }\end{array}$ & $\begin{array}{c}\text { Location } \\
\text { of } \\
\text { scour }\end{array}$ & $\begin{array}{l}\text { Observed } \\
\text { scour } \\
\text { depth } \\
\text { (feet) }\end{array}$ & $\begin{array}{c}\text { a Length of } \\
\text { embankment } \\
\text { blocking flow } \\
\text { (feet) }\end{array}$ & $\begin{array}{l}{ }^{\text {a}} \text { Average } \\
\text { depth of flow } \\
\text { blocked by } \\
\text { embankment } \\
\text { (feet) }\end{array}$ & $\begin{array}{l}{ }^{\text {a Average }} \\
\text { velocity of } \\
\text { flow blocked } \\
\text { by embank- } \\
\text { ment } \\
\text { (feet per } \\
\text { second) }\end{array}$ \\
\hline Abbeville & S.C. 201 & Little River (1) & Left abutment & 4.3 & 620 & 4.7 & 0.7 \\
\hline Abbeville & S.C. 201 & Little River (1) & Right abutment & 3.5 & 479 & 5.7 & .8 \\
\hline Hampton & S.C. 363 & Coosawhatchie River (68) & Left abutment & 5.5 & 993 & 5.2 & .5 \\
\hline Jasper & S-87 & Coosawhatchie River (83) & Left abutment & 5.8 & 1,548 & 3.8 & 6 \\
\hline Jasper & S-87 & Coosawhatchie River (83) & Right abutment & 6.7 & 1,361 & 4.0 & 6 \\
\hline Newberry & U.S. 176 & Indian Creek (106) & Left abutment & 18.0 & 953 & 6.1 & .7 \\
\hline Newberry & U.S. 176 & Indian Creek (106) & Right abutment & 3.2 & 930 & 4.0 & .6 \\
\hline Newberry & S-81 & Enoree River (112) & Right abutment & 13.7 & 606 & 10.5 & 1.2 \\
\hline
\end{tabular}

${ }^{\mathrm{a}}$ Determined from the Water-Surface Profile (WSPRO) model (Shearman, 1990) with the 100-year flow. 


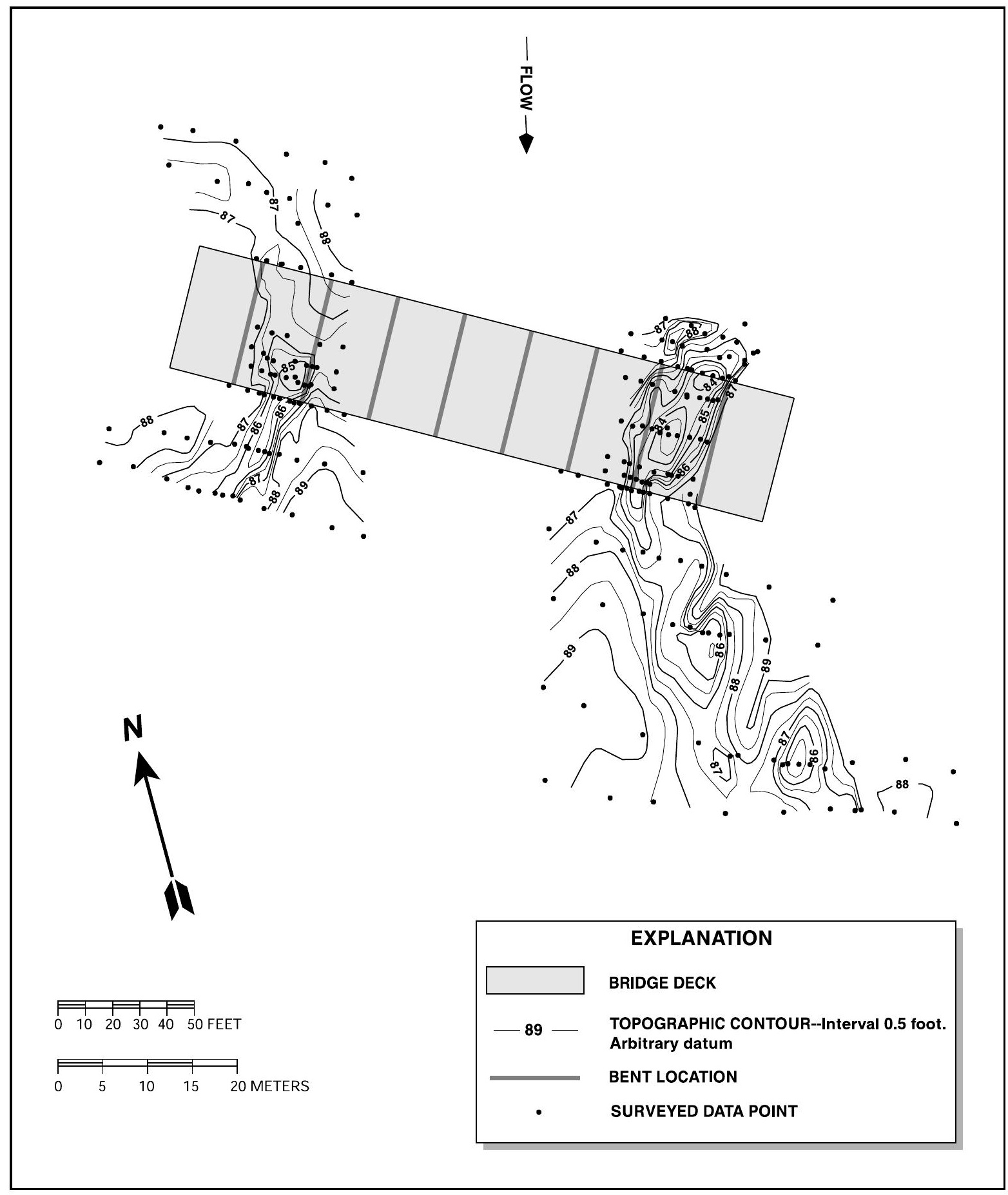

Figure 18. Topography of abutment scour at structure 014020100300 on S.C. Route 201 crossing the Little River in Abbeville County, South Carolina (December 2, 1997). 


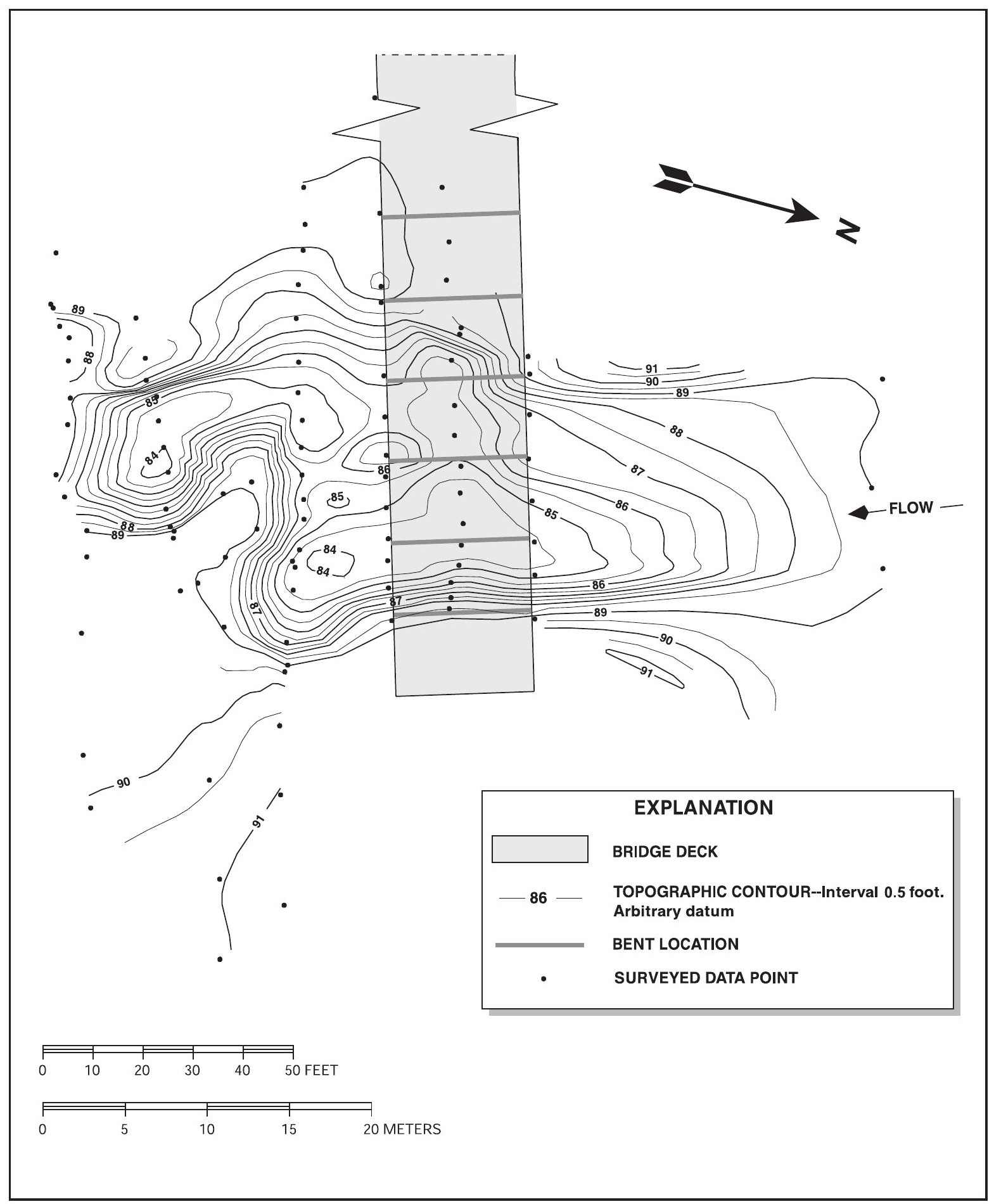

Figure 19. Topography of abutment scour at structure 254036300100 on S.C. Route 363 crossing the Coosawhatchie River in Hampton County, South Carolina (December 17, 1996). 


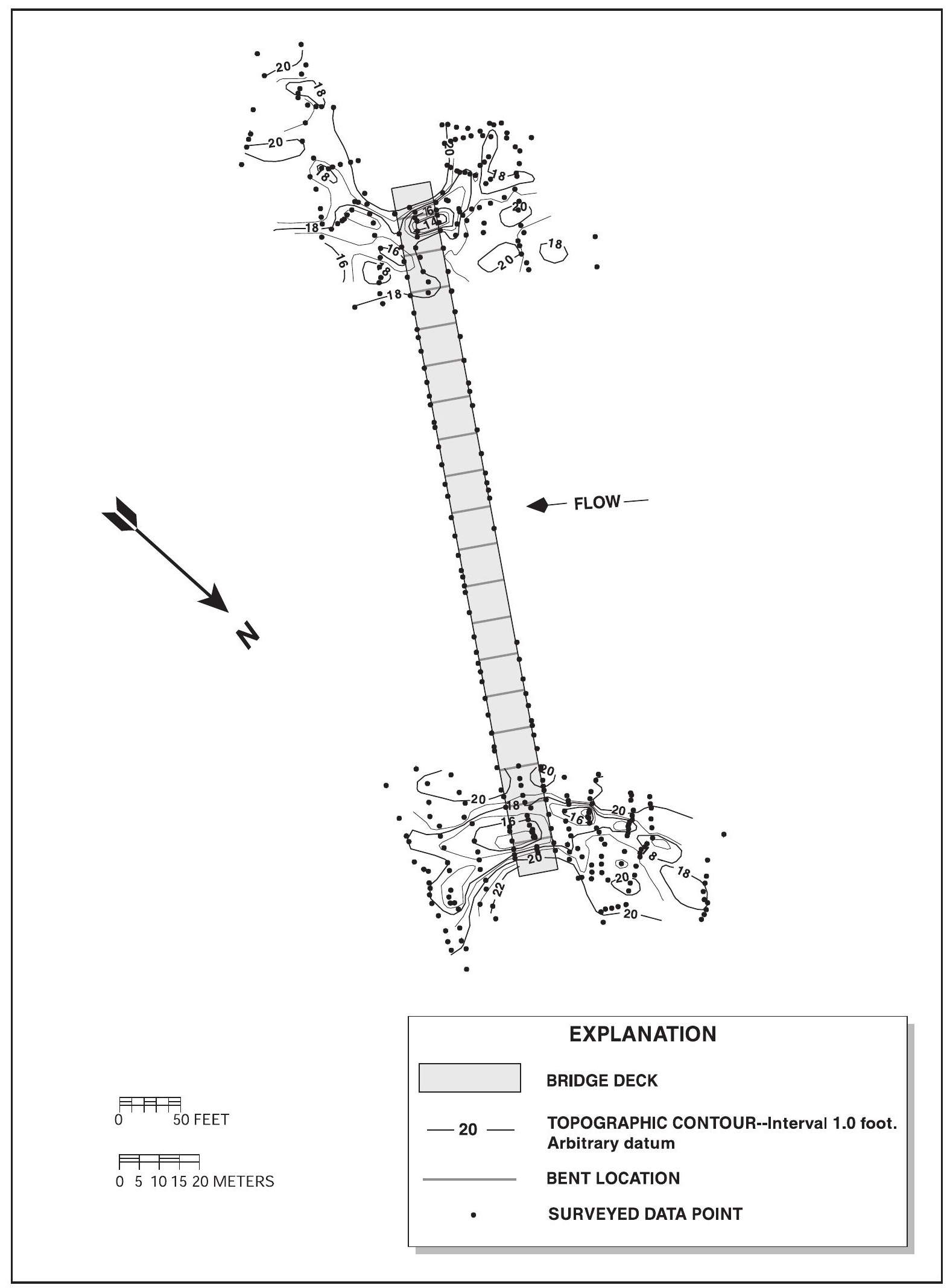

Figure 20. Topography of abutment scour at structure 277008700100 on Road S-87 crossing the Coosawhatchie River in Jasper County, South Carolina (November 12, 1997). 


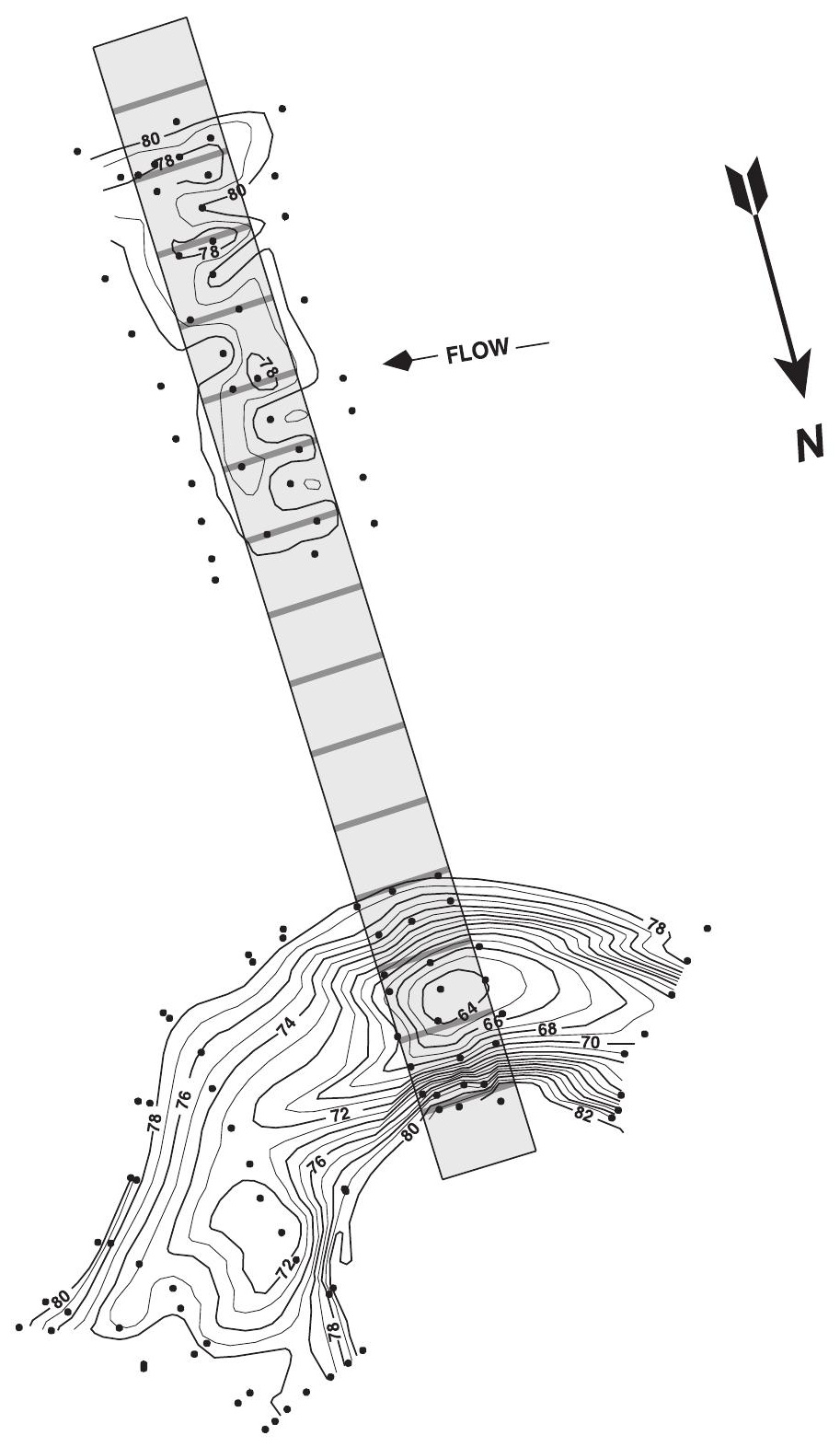

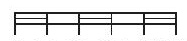

01020304050 FEET

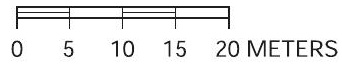

EXPLANATION

BRIDGE DECK

TOPOGRAPHIC CONTOUR--Interval 1.0 foot. Arbitrary datum

BENT LOCATION

SURVEYED DATA POINT

Figure 21. Topography of abutment scour at structure 362017600400 on U.S. Route 176 crossing Indian Creek in Newberry County, South Carorlina (September 23, 1996). 


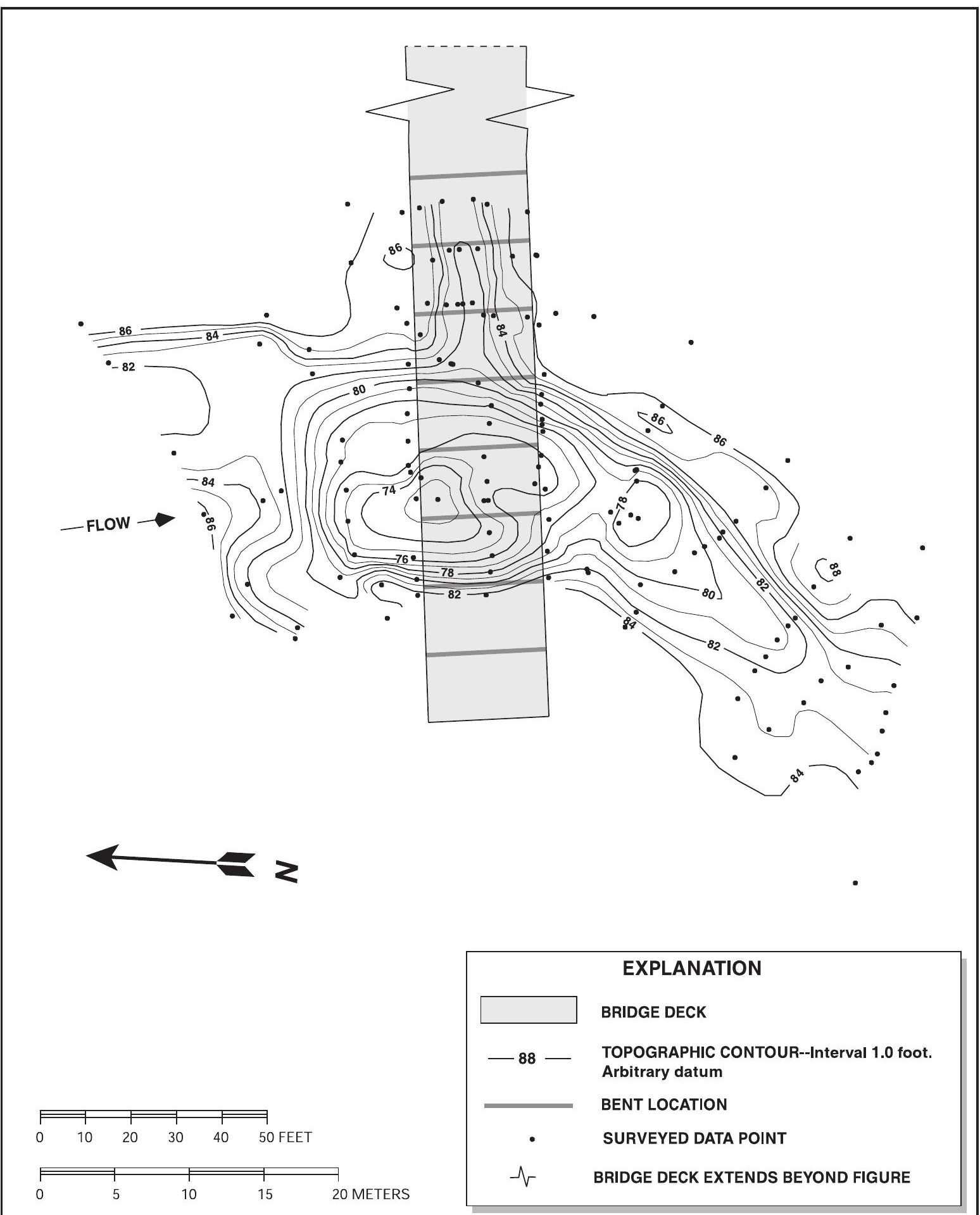

Figure 22. Topography of abutment scour at structure 367008100200 on Road S-81 crossing the Enoree River in Newberry County, South Carolina (April 7, 1997). 
The two-dimensional flow models for these five sites were developed from limited cross-section data taken from previously developed WSPRO models (Shearman, 1990). Because the flood-plain widths at these sites were fairly uniform, surveyed cross sections were shifted by stream slope to selected locations along the river profile. The finite-element grid then was generated using the automatic grid-generation option in SMS (Brigham Young University, 2000). Channel and flood-plain roughness coefficients were set similar to those used in the WSPRO model. The 100-year flow was modeled at each site, and the water-surface elevation determined by the WSPRO model was used at the downstream boundary. The effect of road embankments was incorporated into the models by "turning off" the road embankment elements, thereby forcing flow through the bridge opening. Because the models use template cross sections shifted to selected locations, lateral changes in the location of the main channel are not fully represented. However, flows on the flood plain and flows blocked by the road embankments should be representative of conditions during the 100-year flow, providing understanding of the flow patterns in the abutment area.

\section{Summary}

The U.S. Geological Survey conducted a study in cooperation with the Federal Highway Administration in which predicted abutment-scour depths computed with selected predictive equations were compared with field measurements of abutment-scour depth collected at 144 bridges in South Carolina. Five equations published in the Fourth Edition of "Evaluating Scour at Bridges" (Hydraulic Engineering Circular Number 18) were used in the assessment, including the original Froehlich, the modified Froehlich, the Sturm, the Maryland, and the HIRE equations. The unpublished Young equation also was assessed. Comparisons showed that predicted scour depths frequently overpredicted observed scour and at times were excessive. The comparison also showed that underprediction occurred, but with less frequency.

The field data and hydraulic data used in this investigation have limitations, and it is important to understand these limitations when reviewing the results of this investigation. In particular, the flow conditions that created the observed abutment scour in South Carolina are unknown. To gain insights into hydraulic conditions that may have created the observed scour, hydraulic models were developed for each site using the one-dimensional step-backwater model, WSPRO. The 100year flow was modeled as a common flood at all sites, and the maximum historic flow since bridge construction was modeled at 35 sites where this information was available. Hydraulic data generated from the WSPRO model were used to compute predicted scour for the 100-year flow at all sites and for the maximum historic flow at 35 sites. Although the estimated hydraulic data likely introduce error into the predicted scour computations, the large number of field observations (209) used in the comparisons allowed the trends of an equation to be assessed.

Extensive data and graphs used to compute and compare predicted abutment-scour depths with observed scour depths were compiled in spreadsheets and are included in digital format with this report. In addition to the equation comparison data, WSPRO tube-velocity data, soil-boring data, selected abutment-scour data, and estimates of sediment threshold velocities based on selected predictive methods also are included in digital formal with this report. Appendixes in this report also provide supplemental data that may benefit future research, including a limited literature review on threshold velocities, soil erosion rates at five bridge sites, and a comparison of one-dimensional and two-dimensional numerical models at ten bridge sites.

\section{Selected References}

Benedict, S.T., 2003, Clear-water abutment and contraction scour in the Coastal Plain and Piedmont Provinces of South Carolina, 1996-99: U.S. Geological Survey WaterResources Investigations Report 03-4064, 137 p.

Blodgett, J.C., 1986, Rock riprap design for protection of stream channels near highway structures; v.1, hydraulic characteristics of open channels: U.S. Geological Survey Water-Resources Investigations Report 86-4127, 60 p.

Brigham Young University, 2000, Surface water modeling system: Brigham Young University, version 7.0.01, compiled July 20, 2000.

Chang, F., and Davis, S.R., 1999, Maryland SHA procedure for estimating scour at bridge abutments, Part 2-Clear water scour, in Richardson, E.V., and Lagasse, P.F., eds., Stream stability and scour at highway bridges, ASCE Compendium: Reston, Va., American Society of Civil Engineers, p. 412-416.

Froehlich, D.C., 1989, Local scour at bridge abutments, in Proceedings of the 1989 National Conference on Hydraulic Engineering: New York, American Society of Civil Engineering, p. 13-18.

Laursen, E.M., 1963, An analysis of relief bridge scour: American Society of Civil Engineering Journal of Hydraulic Division, v. 92, no. HY3.

Maryland State Highway Administration, 2005, Evaluating scour at bridges-Manual for hydrologic and hydraulic design: Maryland State Highway Administration, v. 2, chap. 11. 
Maryland State Highway Administration, 2006, Maryland State Highway Administration abutment scour program (ABSCOUR): Maryland State Highway Administration, version 7, build 1.03, compiled January 6, 2006.

Melville, B.W., 1992, Local scour at bridge abutments: American Society of Civil Engineering Journal of Hydraulic Engineering, v. 118 , no. 4, p. 615-630.

Neill, C.R., ed., 1973, Guide to bridge hydraulics: Toronto, Ont., Roads and Transportation Association of Canada, University of Toronto Press, $191 \mathrm{p}$.

Richardson, E.V., and Davis, S.R., 2001, Evaluating scour at bridges: Federal Highway Administration Hydraulic Engineering Circular No. 18, Publication FHWA-NHI-01-001, $378 \mathrm{p}$.
Richardson, E.V., Simons, D.B., and Julien, P.Y., 1990, Highways in the river environment participant notebook: Federal Highway Administration, Publication FHWA-HI-90-016, $650 \mathrm{p}$.

Shearman, J.O., 1990, User's manual for WSPRO-A computer model for water-surface profile computations: Federal Highway Administration, Report FHWA-IP-89-027, 175 p.

Sturm, T.W., 1999, Abutment scour in compound channels, in Richardson, E.V., and Lagasse, P.F., eds., Stream stability and scour at highway bridges, ASCE Compendium: Reston, Va., American Society of Civil Engineers, p. 443-456. 


\section{Appendixes}

A - South Carolina bridge-scour study sites and reference numbers in figure 1.

B - Description of spreadsheets used in the equation assessments.

C - Description of compiled data including WSPRO tube-velocity data, soil-boring data, selected abutmentscour data, and threshold velocity data.

D - A comparison of selected methods for estimating sediment threshold velocities.

$\mathrm{E}$ - Determination of soil erosion rates at five sites in South Carolina.

F-A 2-D numerical model study on flow past the abutments of highway bridges in South Carolina. 


\section{Appendix A}

South Carolina bridge-scour study sites and reference numbers in figure 1. 
Appendix A. South Carolina bridge-scour study sites and reference numbers in figure 1. (Note: At twin bridge crossings, only the structure number for the north- or east-bound bridge is provided.)

[S.C., South Carolina route; I, interstate highway; U.S., United States highway; S, secondary road]

\begin{tabular}{|c|c|c|c|c|}
\hline $\begin{array}{l}\text { Reference } \\
\text { number } \\
\text { in } \\
\text { figure } 1\end{array}$ & County & Road & Stream & Structure number \\
\hline 1 & Abbeville & S.C. 201 & Little River & 014020100300 \\
\hline 2 & Aiken & $\mathrm{I}-20$ & South Edisto River & 021002021200 \\
\hline 3 & Allendale & U.S. 301 & Salkehatchie River & 032030100600 \\
\hline 4 & Allendale & U.S. 301 & Salkehatchie River & 032030100700 \\
\hline 5 & Allendale & S.C. 3 & King Creek & 034000300100 \\
\hline 6 & Allendale & S.C. 3 & Gaul Creek & 034000300200 \\
\hline 7 & Allendale & $\mathrm{S}-21$ & Coosawhatchie River & 037002100100 \\
\hline 8 & Allendale & S-107 & Gaul Branch & 037010700100 \\
\hline 9 & Anderson & $\mathrm{I}-85$ & Brushy Creek & 041008511200 \\
\hline 10 & Anderson & $S-263$ & Rocky River & 047026300100 \\
\hline 11 & Calhoun & U.S. 176 & Flea Bite Creek & 092017600400 \\
\hline 12 & Cherokee & S.C. 5 & Buffalo Creek & 114000500200 \\
\hline 13 & Cherokee & $\mathrm{S}-348$ & Buffalo Creek & 117034800100 \\
\hline 14 & Chester & $\mathrm{I}-77$ & Fishing Creek & 121007710700 \\
\hline 15 & Chester & S.C. 9 & Turkey Creek & 124000900200 \\
\hline 16 & Chester & S.C. 9 & Fishing Creek & 124000901100 \\
\hline 17 & Chester & S.C. 72 & Sandy River & 124007200200 \\
\hline 18 & Chester & S.C. 97 & Turkey Creek & 124009700100 \\
\hline 19 & Chester & S.C. 97 & Rocky Creek & 124009700800 \\
\hline 20 & Chester & S.C. 215 & Sandy River & 124021500200 \\
\hline 21 & Chester & S.C. 223 & Fishing Creek & 124022300100 \\
\hline 22 & Chester & S.C. 901 & Rocky Creek & 124090100200 \\
\hline 23 & Chesterfield & S.C. 9 & Thompson Creek & 134000900400 \\
\hline 24 & Chesterfield & S.C. 109 & Thompson Creek & 134010900100 \\
\hline 25 & Clarendon & U.S. 15 & Sammy Swamp & 142001500400 \\
\hline 26 & Clarendon & U.S. 378 & Douglas Swamp & 142037800300 \\
\hline 27 & Clarendon & U.S. 521 & Ox Swamp & 142052100300 \\
\hline 28 & Clarendon & S.C. 261 & Sammy Swamp & 144026100100 \\
\hline 29 & Colleton & U.S. 21 & Sandy Run Creek & 152002100300 \\
\hline 30 & Colleton & S.C. 63 & Deep Creek & 154006300300 \\
\hline 31 & Colleton & S.C. 63 & Little Salkehatchie River & 154006300400 \\
\hline 32 & Colleton & S.C. 63 & Little Salkehatchie River & 154006300500 \\
\hline 33 & Colleton & S.C. 63 & Little Salkehatchie River & 154006300600 \\
\hline 34 & Colleton & S.C. 63 & Little Salkehatchie River & 154006300700 \\
\hline 35 & Colleton & S.C. 64 & Jones Swamp & 154006400700 \\
\hline 36 & Colleton & S.C. 212 & Buckhead Creek & 154021200100 \\
\hline 37 & Colleton & S.C. 212 & Buckhead Creek & 154021200200 \\
\hline 38 & Colleton & S.C. 641 & Willow Swamp & 154064100200 \\
\hline
\end{tabular}


Appendix A. South Carolina bridge-scour study sites and reference numbers in figure 1. (Note: At twin bridge crossings, only the structure number for the north- or east-bound bridge is provided.) — Continued

[S.C., South Carolina route; I, interstate highway; U.S., United States highway; S, secondary road]

\begin{tabular}{|c|c|c|c|c|}
\hline $\begin{array}{c}\text { Reference } \\
\text { number } \\
\text { in } \\
\text { figure } 1\end{array}$ & County & Road & Stream & Structure number \\
\hline 39 & Dillon & S.C. 41 & Buck Swamp & 174004107100 \\
\hline 40 & Dillon & S.C. 41 & Buck Swamp & 174004107200 \\
\hline 41 & Dorchester & I-26 & Four Hole Swamp & 181002620300 \\
\hline 42 & Dorchester & U.S. 78 & Cattle Creek & 182007800100 \\
\hline 43 & Dorchester & U.S. 78 & Polk Swamp & 182007800200 \\
\hline 44 & Edgefield & S.C. 230 & Horne Creek & 194023000500 \\
\hline 45 & Fairfield & $\mathrm{I}-77$ & Little Wateree Creek & 201007710600 \\
\hline 46 & Fairfield & $\mathrm{I}-77$ & Big Wateree Creek & 201007710700 \\
\hline 47 & Fairfield & U.S. 21 & Dutchmans Creek & 202002100200 \\
\hline 48 & Fairfield & U.S. 21 & Big Wateree Creek & 202002100400 \\
\hline 49 & Fairfield & S.C. 200 & Wateree Creek & 204020000500 \\
\hline 50 & Florence & $\mathrm{I}-95$ & Lake Swamp & 211009510400 \\
\hline 51 & Florence & I-95 & Pee Dee River & 211009511400 \\
\hline 52 & Florence & U.S. 52 & Lynches Lake & 212005200100 \\
\hline 53 & Florence & U.S. 52 & Jefferies Creek & 212005200700 \\
\hline 54 & Florence & U.S. 76 & Great Pee Dee River & 212007621100 \\
\hline 55 & Florence & U.S. 301 & Douglas Swamp & 212030100100 \\
\hline 56 & Florence & U.S. 301 & Sparrow Swamp & 212030100400 \\
\hline 57 & Florence & U.S. 378 & Big Swamp & 212037801000 \\
\hline 58 & Florence & S.C. 51 & Big Swamp & 214005100200 \\
\hline 59 & Florence & S.C. 51 & Middle Swamp & 214005100400 \\
\hline 60 & Florence & S.C. 51 & Jeffries Creek & 214005100500 \\
\hline 61 & Florence & S.C. 403 & Deep Hole Swamp & 214040300500 \\
\hline 62 & Greenville & S.C. 417 & Horse Pen Creek & 234041700200 \\
\hline 63 & Greenville & $S-40$ & South Saluda River & 237004000100 \\
\hline 64 & Greenville & S-68 & Reedy River & 237006800100 \\
\hline 65 & Greenville & S-125 & Saluda River & 237012500100 \\
\hline 66 & Greenwood & S.C. 246 & Wilson Creek & 244024600200 \\
\hline 67 & Hampton & U.S. 601 & Coosawhatchie River & 252060100300 \\
\hline 68 & Hampton & S.C. 363 & Coosawhatchie River & 254036300100 \\
\hline 69 & Hampton & S-13 & Whippy Swamp & 257001300500 \\
\hline 70 & Horry & U.S. 501 & Waccamaw River & 262050103100 \\
\hline 71 & Horry & U.S. 501 & Waccamaw River & 262050103200 \\
\hline 72 & Horry & U.S. 501 & Waccamaw River & 262050103300 \\
\hline 73 & Horry & U.S. 501 & Waccamaw River & 262050105200 \\
\hline 74 & Horry & U.S. 501 & Little Pee Dee River & 262050110100 \\
\hline 75 & Horry & S.C. 22 & Waccamaw River & 264002220200 \\
\hline 76 & Horry & S.C. 22 & Waccamaw River & 264002220300 \\
\hline 77 & Horry & S.C. 22 & Waccamaw River & 264002220400 \\
\hline
\end{tabular}


Appendix A. South Carolina bridge-scour study sites and reference numbers in figure 1. (Note: At twin bridge crossings, only the structure number for the north- or east-bound bridge is provided.) — Continued

[S.C., South Carolina route; I, interstate highway; U.S., United States highway; S, secondary road]

\begin{tabular}{|c|c|c|c|c|}
\hline $\begin{array}{l}\text { Reference } \\
\text { number } \\
\text { in } \\
\text { figure } 1\end{array}$ & County & Road & Stream & Structure number \\
\hline 78 & Jasper & U.S. 278 & Cypress Creek & 272027800100 \\
\hline 79 & Jasper & U.S. 321 & Cypress Swamp & 272032100700 \\
\hline 80 & Jasper & U.S. 321 & Black Swamp Long Branch & 272032100800 \\
\hline 81 & Jasper & S.C. 3 & Cypress Creek & 274000300200 \\
\hline 82 & Jasper & S.C. 336 & Great Swamp & 274033600100 \\
\hline 83 & Jasper & S-87 & Coosawhatchie River & 277008700100 \\
\hline 84 & Kershaw & U.S. 1 & Little Lynches River & 282000100500 \\
\hline 85 & Kershaw & U.S. 521 & Granneys Quarter Creek & 282052100900 \\
\hline 86 & Kershaw & S.C. 97 & White Oak Creek & 284009700300 \\
\hline 87 & Kershaw & S.C. 97 & Granneys Quarter Creek & 284009700400 \\
\hline 88 & Laurens & S.C. 49 & Enoree River & 304004900400 \\
\hline 89 & Laurens & S.C. 72 & Little River & 304007200500 \\
\hline 90 & Laurens & S.C. 72 & Duncan Creek & 304007201200 \\
\hline 91 & Laurens & S-36 & Reedy River & 307003600200 \\
\hline 92 & Laurens & S-102 & Little River & 307010200100 \\
\hline 93 & Laurens & S-112 & Enoree River & 307011200100 \\
\hline 94 & Laurens & S-263 & Enoree River & 307026300100 \\
\hline 95 & Lexington & S.C. 113 & North Edisto River & 324011300100 \\
\hline 96 & McCormick & S.C. 67 & Cuffeytown Creek & 334006700100 \\
\hline 97 & Marion & U.S. 76 & Great Pee Dee River & 342007620100 \\
\hline 98 & Marion & U.S. 501 & Smith Swamp & 342050100300 \\
\hline 99 & Marion & U.S. 501 & Little Pee Dee River & 342050110700 \\
\hline 100 & Marion & U.S. 501 & Little Pee Dee River & 342050110800 \\
\hline 101 & Marion & U.S. 501 & Little Pee Dee River & 342050110900 \\
\hline 102 & Marion & U.S. 501 & Little Pee Dee River & 342050111000 \\
\hline 103 & Marion & U.S. 501 & Little Pee Dee River & 342050111100 \\
\hline 104 & Marion & S.C. 41 & Maiden Down Swamp & 344004100800 \\
\hline 105 & Marion & U.S. 576 & Smith Swamp & 344057620200 \\
\hline 106 & Newberry & U.S. 176 & Indian Creek & 362017600400 \\
\hline 107 & Newberry & U.S. 176 & Kings Creek & 362017600500 \\
\hline 108 & Newberry & S.C. 34 & Little River & 364003400300 \\
\hline 109 & Newberry & S.C. 121 & Saluda River & 364012100101 \\
\hline 110 & Newberry & S-32 & Indian Creek & 367003200200 \\
\hline 111 & Newberry & $\mathrm{S}-45$ & Enoree River & 367004500100 \\
\hline 112 & Newberry & $\mathrm{S}-81$ & Enoree River & 367008100200 \\
\hline 113 & Newberry & S-299 & Cannons Creek & 367029900100 \\
\hline 114 & Oconee & U.S. 76 & Coneross Creek & 372007620500 \\
\hline 115 & Oconee & S.C. 11 & Colonels Fork Creek & 374001100500 \\
\hline 116 & Oconee & S.C. 183 & Coneross Creek & 374018300200 \\
\hline
\end{tabular}


Appendix A. South Carolina bridge-scour study sites and reference numbers in figure 1. (Note: At twin bridge crossings, only the structure number for the north- or east-bound bridge is provided.) — Continued

[S.C., South Carolina route; I, interstate highway; U.S., United States highway; S, secondary road]

\begin{tabular}{|c|c|c|c|c|}
\hline $\begin{array}{l}\text { Reference } \\
\text { number } \\
\text { in } \\
\text { figure } 1\end{array}$ & County & Road & Stream & Structure number \\
\hline 117 & Orangeburg & U.S. 176 & Providence Swamp & 382017600200 \\
\hline 118 & Orangeburg & U.S. 176 & Providence Swamp & 382017600300 \\
\hline 119 & Orangeburg & U.S. 301 & Four Hole Swamp & 382030110800 \\
\hline 120 & Orangeburg & U.S. 301 & Goodbys Swamp & 382030110900 \\
\hline 121 & Orangeburg & S.C. 453 & Four Hole Swamp (Br 1) & 384045300200 \\
\hline 122 & Richland & U.S. 321 & Crane Creek & 402032100200 \\
\hline 123 & Saluda & U.S. 378 & Red Bank Creek & 412037800100 \\
\hline 124 & Saluda & U.S. 378 & Little Saluda River & 412037800200 \\
\hline 125 & Spartanburg & U.S. 29 & South Tyger River & 422002900100 \\
\hline 126 & Spartanburg & U.S. 176 & Lawsons Fork Creek & 422017620900 \\
\hline 127 & Spartanburg & S.C. 146 & Enoree River & 424014600100 \\
\hline 128 & Spartanburg & S.C. 296 & Enoree River & 424029600100 \\
\hline 129 & Spartanburg & S-62 & South Tyger River & 427006200500 \\
\hline 130 & Spartanburg & $\mathrm{S}-118$ & Enoree River & 427011800001 \\
\hline 131 & Spartanburg & S-242 & South Tyger River & 427024200200 \\
\hline 132 & Sumter & U.S. 401 & Rock Bluff Creek & 432040100100 \\
\hline 133 & Sumter & U.S. 401 & Rock Bluff Creek & 432040100200 \\
\hline 134 & Union & S.C. 56 & Enoree River & 444005600100 \\
\hline 135 & Union & $\mathrm{S}-22$ & Enoree River & 447002200100 \\
\hline 136 & Williamsburg & S.C. 261 & Paisley Swamp & 454026100300 \\
\hline 137 & Williamsburg & S.C. 261 & Boggy Swamp & 454026100400 \\
\hline 138 & Williamsburg & S.C. 261 & Indiantown Swamp & 454026100500 \\
\hline 139 & Williamsburg & S-16 & Johnson's Creek & 457001600100 \\
\hline 140 & York & S.C. 97 & Bullocks Branch & 464009700300 \\
\hline 141 & York & S.C. 322 & Fishing Creek & 464032200300 \\
\hline 142 & York & S.C. 322 & Tools Fork Creek & 464032200500 \\
\hline 143 & York & S.C. 557 & Crowders Creek & 464055700200 \\
\hline 144 & York & S-721 & Taylors Creek & 467072100100 \\
\hline
\end{tabular}

NOTE: The following bridge sites have been excluded from the above list because the area of scour at the bridge was disturbed by construction equipment, bringing the field measurements of scour into question.

$\begin{array}{llll}\text { Allendale } & \text { U.S. } 301 & \text { Salkehatchie River } & 032030100800 \\ \text { Horry } & \text { S.C. } 22 & \text { Waccamaw River } & 264002220100\end{array}$




\section{Appendix B}

Description of spreadsheets used in the equation assessments. 
Variables used to compute predicted abutment-scour depths and the results of those computations have been stored in electronic spreadsheets and can be viewed and(or) downloaded at the links presented in this appendix. Separate links are provided for each equation. Under each link are spreadsheets for data in the Piedmont and Coastal Plain and for the 100-year flow and maximum historic flows. A brief description of the contents for each spreadsheet follows.

\section{Original and Modified Froehlich Equations}

Variables used to compute predicted scour depths and the results of those computations for the original Froehlich equation (Richardson and Davis, 2001) and the modified Froehlich equation (Richardson and Davis, 2001) are included in the same spreadsheet. The file names for these spreadsheets and a brief description of the data in each file are presented in table B-1. Each of these spreadsheets contains 17 worksheets that contain data or graphs used to compute predicted scour and compare with observed scour. Table B-2 lists the 17 worksheets and briefly describes the content of each worksheet. These files can be viewed and(or) downloaded at the following link:

http://pubs.water.usgs.gov/ofr03-295/data.html\#Froehlich

Table B-1. Spreadsheet file names containing data used to compute predicted abutment-scour depths for the original Froehlich (Richardson and Davis, 2001) and modified Froehlich (Richardson and Davis, 2001) equations.

File name

FROEHLICH PIEDMONT Q100

FROEHLICH PIEDMONT QHIS

\begin{tabular}{cc} 
FROEHLICH COASTAL Q100 & $\begin{array}{c}\text { at sites in the Piedmont } \\
\text { flow abutment scour for the 100-year }\end{array}$ \\
FROEHLICH COASTAL QHIS & $\begin{array}{r}\text { Predicted abutment scour for historic flows } \\
\text { at sites in the Coastal Plain }\end{array}$ \\
\hline
\end{tabular}

\section{File description}

Predicted abutment scour for the 100-year flow at sites in the Piedmont Predicted abutment scour for historic flows 
Table B-2. Description of data on worksheets in the digital spreadsheets used to compute predicted abutmentscour depths for the original Froehlich (Richardson and Davis, 2001) and modified Froehlich (Richardson and Davis, 2001) equations.

\begin{tabular}{|c|c|}
\hline Worksheet name & Description of data on worksheet \\
\hline README & Briefly describes the content of each worksheet within the spreadsheet. \\
\hline APP VEL DATA & $\begin{array}{l}\text { Contains hydraulic and tube-velocity data generated by the WSPRO model (Shearman, 1990) } \\
\text { for the approach cross section. }\end{array}$ \\
\hline BR VEL DATA & $\begin{array}{l}\text { Contains hydraulic and tube-velocity data generated by the WSPRO model (Shearman, 1990) } \\
\text { for the bridge cross section. }\end{array}$ \\
\hline PLOT DATA & Contains selected data used to develop graph on the "ABUTMENT PLOT" worksheet. \\
\hline ABUTMENT PLOT & $\begin{array}{l}\text { Contains a graph showing the approach cross section velocity-distribution curve determined } \\
\text { from the WSPRO tube-velocity data. The graph also shows the approximate location of the } \\
\text { original and modified embankment lengths and the bridge top width on the approach cross } \\
\text { section. The graph for a given bridge site can be viewed by entering the number in cell 'D1' } \\
\text { that corresponds to the row number on the "APP VEL DATA" worksheet in which the data for } \\
\text { the bridge of interest resides. This graph was used to visually determine areas of ineffective } \\
\text { flow toward the edge of the flood plain. }\end{array}$ \\
\hline
\end{tabular}

Contains the data and calculations used to compute the predicted abutment-scour depths. The data are organized by columns in the following manner:

Site identification:

CALC

\section{ENVELOPES}

Fig 1

Fig 2

Fig 3

Fig 4

Fig 5

Fig 6

Fig 7

Fig 8

Fig 9

Fig 10 10 .
Columns A through $\mathrm{F}$

Column G

Columns H through U

Columns V through X

Columns Y through AC

Columns AB through AG.

Contains the South Carolina field data envelope and one-to-one line used in figures 1 through

Compares the original Froehlich equation (Richardson and Davis, 2001) with the modified Froehlich equation (Richardson and Davis, 2001). Safety factor is included. Compares the modified Froehlich equation (Richardson and Davis, 2001) with field observations. Safety factor is included.

Compares the modified Froehlich equation (Richardson and Davis, 2001) with field observations. Safety factor is not included.

Compares the modified embankment length with the original embankment length.

Compares the modified Froehlich equation (Richardson and Davis, 2001) with the embankment-length envelope of the field data. Safety factor is included.

Compares the modified Froehlich equation (Richardson and Davis, 2001) with the embankment-length envelope of the field data. Safety factor is not included.

Compares the original Froehlich equation (Richardson and Davis, 2001) with field observations. Safety factor is included.

Compares the original Froehlich equation (Richardson and Davis, 2001) with field observations. Safety factor is not included.

Compares the original Froehlich equation (Richardson and Davis, 2001) with the embankment-length envelope of the field data. Safety factor is included.

Compares the original Froehlich equation (Richardson and Davis, 2001) with the embankment-length envelope of the field data. Safety factor is not included. 


\section{Sturm Equation}

Variables used to compute predicted scour depths with the Sturm equation (Richardson and Davis, 2001) are tabulated in electronic spreadsheets. The file names for these spreadsheets and a brief description of the data in each file are presented in table B-3. Each of these spreadsheets contains seven worksheets that contain data or graphs used to compute predicted scour and compare with observed scour. Table B-4 lists the seven worksheets and briefly describes the content of each worksheet. These files can be viewed and(or) downloaded at the following link:

\section{http://pubs.water.usgs.gov/ofr03-295/data.html\#Sturm}

Table B-3. Spreadsheet file names containing data used to compute predicted abutment-scour depths for the Sturm equation (Richardson and Davis, 2001).

\begin{tabular}{cc}
\hline Fle name & File description \\
\hline STURM PIEDMONT Q100 & $\begin{array}{r}\text { Predicted abutment scour for the 100-year } \\
\text { flow at sites in the Piedmont }\end{array}$ \\
STURM PIEDMONT QHIS & $\begin{array}{r}\text { Predicted abutment scour for historic flows } \\
\text { at sites in the Piedmont }\end{array}$ \\
STURM COASTAL Q100 & $\begin{array}{c}\text { Predicted abutment scour for the 100-year } \\
\text { flow at sites in the Coastal Plain }\end{array}$ \\
STURM COASTAL QHIS & $\begin{array}{c}\text { Predicted abutment scour for historic flows } \\
\text { at sites in the Coastal Plain }\end{array}$ \\
\hline
\end{tabular}

Table B-4. Description of data on worksheets in the digital spreadsheets used to compute predicted abutmentscour depths for the Sturm equation (Richardson and Davis, 2001).

\section{Worksheet name Description of data on worksheet}

README Briefly describes the content of each worksheet within the spreadsheet.

CALC Contains the data and calculations used to compute the predicted abutment-scour depths.

ENVELOPES Contains the South Carolina field data envelope and one-to-one line used in figures 1 through 4.

Fig 1

Compares the Sturm equation (Richardson and Davis, 2001) with the embankment-length envelope of the field data. Safety factor is included.

Fig 2 Compares the Sturm equation (Richardson and Davis, 2001) with the embankment-length envelope of the field data. Safety factor is not included.

Fig 3 Compares the Sturm equation (Richardson and Davis, 2001) with field observations. Safety factor is included.

Fig 4 Compares the Sturm equation (Richardson and Davis, 2001) with field observations. Safety factor is not included. 


\section{Maryland Equation}

The ABSCOUR computer program (Maryland State Highway Administration, 2006) was used to compute predicted scour for the Maryland equation (Richardson and Davis, 2001). The ABSCOUR computer program uses a modified version of the Maryland equation, and results may vary slightly from the equation published in Richardson and Davis (2001). ABSCOUR stores computational data for a given bridge site in a unique input file. Data in these input files include all of the hydraulic and site data required to compute abutment-scour depth with the Maryland equation. These data can be viewed by opening the input file with the ABSCOUR program. User options, such as the selection of a critical velocity equation, can be modified in the input file, and scour depths can be quickly recomputed to assess the effect of selected conditions. The ABSCOUR program and all input files are included under the Maryland equation link and are organized in subdirectories as shown in figure B-1. Input files are stored under the "INPUT FILES" subdirectory (fig. B-1) and are grouped by region (Piedmont and Coastal Plain) and then by flow conditions (100-year flow and historic flow). To associate an input file with a particular site, input file names have the general structure "County, Road, Stream." For example, the bridge on S.C. Route 201 crossing the Little River in Abbeville County has the input file name "Abbeville, SC 201, Little River." The version of the ABSCOUR program used in this study and supporting documentation are included under the subdirectory "PROGRAM" (fig. B-1). The input and output data for the ABSCOUR program were tabulated in electronic spreadsheets. The file names for these spreadsheets and a brief description of the data in each file are presented in table B-5. Each of these spreadsheets has 12 worksheets that contain data or graphs used to compare predicted scour with observed scour. Table B-6 lists the 12 worksheets and briefly describes the content of each worksheet. These files can be viewed and(or) downloaded at the following link:

\section{http://pubs.water.usgs.gov/ofr03-295/data.html\#Maryland}

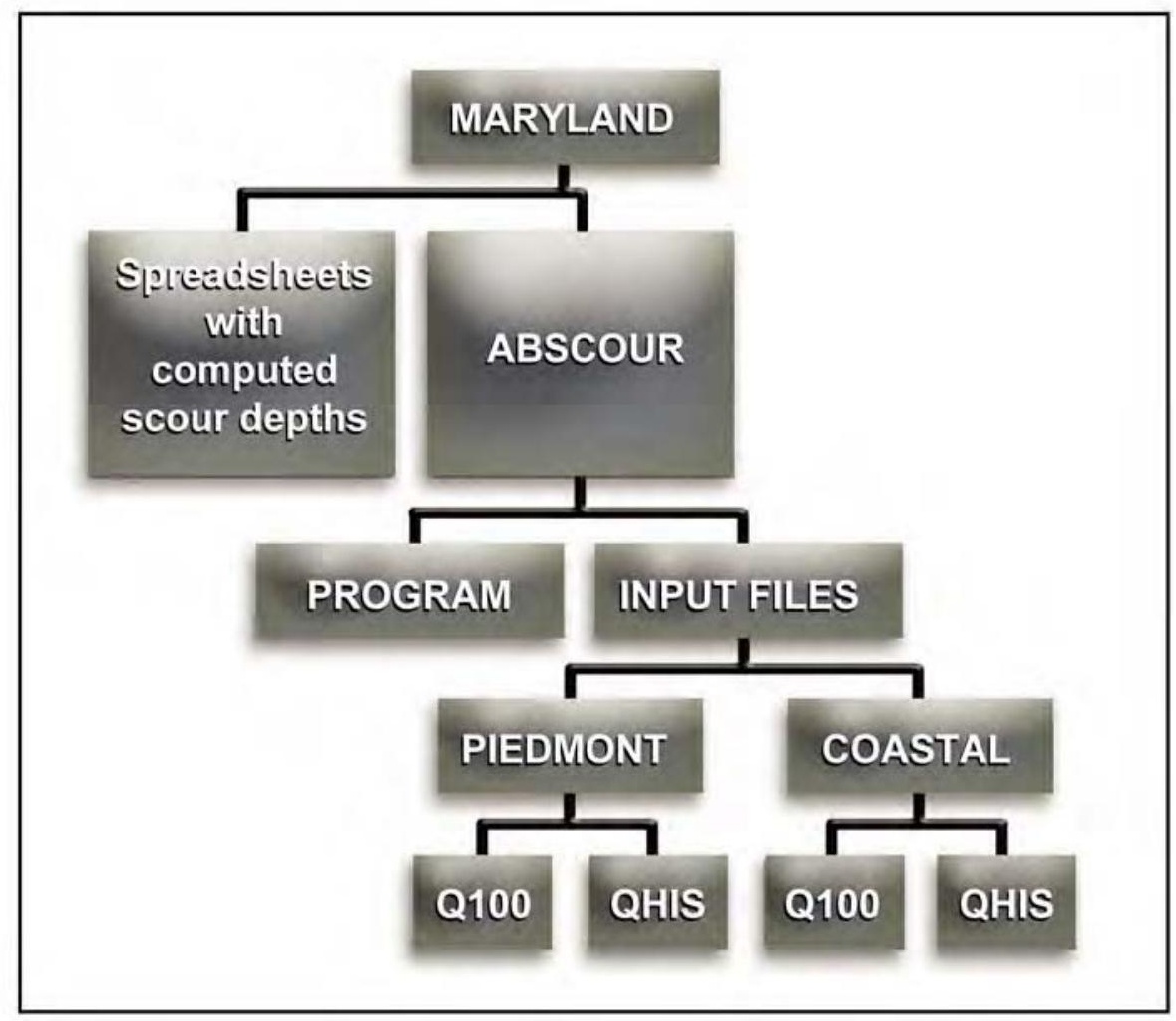

Figure B-1. Directory structure for stored data used to compute scour depths with the Maryland equation. 
Table B-5. Spreadsheet file names containing data used to compute predicted abutment-scour depths for the Maryland equation (Richardson and Davis, 2001).

\begin{tabular}{|cc|}
\hline File name & \multicolumn{1}{c|}{ File description } \\
\hline MARYLAND PIEDMONT Q100 & $\begin{array}{c}\text { Predicted abutment scour for the 100- } \\
\text { year flow at sites in the Piedmont }\end{array}$ \\
\hline MARYLAND PIEDMONT QHIS & $\begin{array}{c}\text { Predicted abutment scour for historic } \\
\text { flows at sites in the Piedmont }\end{array}$ \\
MARYLAND COASTAL Q100 & $\begin{array}{c}\text { Predicted abutment scour for the 100- } \\
\text { year flow at sites in the Coastal Plain }\end{array}$ \\
\hline MARYLAND COASTAL QHIS & $\begin{array}{c}\text { Predicted abutment scour for historic } \\
\text { flows at sites in the Coastal Plain }\end{array}$ \\
\hline
\end{tabular}

Table B-6. Description of data on worksheets in the digital spreadsheets used to compute predicted abutment-scour depths for the Maryland equation (Richardson and Davis, 2001).

\section{Worksheet name Description of data on worksheet}

README Briefly describes the content of each worksheet within the spreadsheet.

CALC (Laursen) Contains the input and output data for the ABSCOUR computer program using Laursen's (1963) critical velocity.

CALC (Neill) Contains the input and output data for the ABSCOUR computer program using Neill's (1973) competent velocity.

ENVELOPES Contains the South Carolina field data envelope and one-to-one line used in figures 1 through 8.

Compares the Maryland equation (Richardson and Davis, 2001) with the embankment-length envelope of the field data. Neill's (1973) competent velocity is used. Safety factor is not included.

Fig 2 Compares the Maryland equation (Richardson and Davis, 2001) with the embankment-length envelope of the field data. Neill's (1973) competent velocity is used. Safety factor is included.

Fig 3 Compares the Maryland equation (Richardson and Davis, 2001) with field observations. Neill's (1973) competent velocity is used. Safety factor is not included.

Fig $4 \quad$ Compares the Maryland equation (Richardson and D

Compares the Maryland equation (Richardson and Davis, 2001) with the embankment-length
the field data. Laursen's (1963) critical velocity equation is used. Safety factor is not included.

Fig 6 Compares the Maryland equation (Richardson and Davis, 2001) with the embankment-length

Fig 7 Compares the Maryland equation (Richardson and Davis, 2001)

Fig 8 Compares the Maryland equation (Richardson and Davis, 2001) with field observations. Laursen's (1963) critical velocity equation is used. Safety factor is included. 


\section{HIRE Equation}

Variables used to compute predicted scour depths with the HIRE equation (Richardson and Davis, 2001) are tabulated in electronic spreadsheets. The file names for these spreadsheets and a brief description of the data in each file are presented in table B-7. Each of these spreadsheets contains five worksheets that contain data or graphs used to compute predicted scour and compare with observed scour. Table B-8 lists the five worksheets and briefly describes the content of each worksheet. These files can be viewed and(or) downloaded at the following link:

http://pubs.water.usgs.gov/ofr03-295/data.html\#HIRE

Table B-7. Spreadsheet file names containing data used to compute predicted abutment-scour depths for the HIRE equation (Richardson and Davis, 2001).

\begin{tabular}{cc}
\hline File name & File description \\
\hline HIRE PIEDMONT Q100 & $\begin{array}{r}\text { Predicted abutment scour for the 100-year } \\
\text { flow at sites in the Piedmont }\end{array}$ \\
HIRE PIEDMONT QHIS & $\begin{array}{r}\text { Predicted abutment scour for historic flows } \\
\text { at sites in the Piedmont }\end{array}$ \\
HIRE COASTAL Q100 & $\begin{array}{c}\text { Predicted abutment scour for the 100-year } \\
\text { flow at sites in the Coastal Plain }\end{array}$ \\
HIRE COASTAL QHIS & $\begin{array}{c}\text { Predicted abutment scour for historic flows } \\
\text { at sites in the Coastal Plain }\end{array}$ \\
\hline
\end{tabular}

Table B-8. Description of data on worksheets in the digital spreadsheets used to compute predicted abutmentscour depths for the HIRE equation (Richardson and Davis, 2001).

\section{Worksheet name \\ Description of data on worksheet}

README Briefly describes the content of each worksheet within the spreadsheet.

CALC Contains the data and calculations used to compute the predicted abutment-scour depths.

ENVELOPES Contains the South Carolina field data envelope and one-to-one line used in figures 1 and 2.

Fig 1 Compares the HIRE equation (Richardson and Davis, 2001) with field observations.

Fig 2 Compares the HIRE equation (Richardson and Davis, 2001) with the embankment-length envelope of the field data. 


\section{Young Equation}

Variables used to compute predicted scour depths with the Young equation (K. Young, K. Saffarinia, and J.S. Jones, Federal Highway Administration, unpub. data, 2002) are tabulated in electronic spreadsheets. The file names for these spreadsheets and a brief description of the data in each file are presented in table B-9. Each of these spreadsheets has five worksheets that contain data or graphs used to compute predicted scour and compare with observed scour. Table B-10 lists the five worksheets and briefly describes the content of each worksheet. These files can be viewed and(or) downloaded at the following link:

\section{http://pubs.water.usgs.gov/ofr03-295/data.html\#Young}

Table B-9. Spreadsheet file names containing data used to compute predicted abutment-scour depths for the Young equation (K. Young, K. Saffarinia, and J.S. Jones, Federal Highway Administration, unpub. data, 2002).

\begin{tabular}{cc}
\hline File name & File description \\
\hline YOUNG PIEDMONT Q100 & $\begin{array}{r}\text { Predicted abutment scour for the 100-year } \\
\text { flow at sites in the Piedmont }\end{array}$ \\
\hline YOUNG PIEDMONT QHIS & $\begin{array}{r}\text { Predicted abutment scour for historic flows } \\
\text { at sites in the Piedmont }\end{array}$ \\
YOUNG COASTAL Q100 & $\begin{array}{c}\text { Predicted abutment scour for the 100-year } \\
\text { flow at sites in the Coastal Plain }\end{array}$ \\
YOUNG COASTAL QHIS & $\begin{array}{c}\text { Predicted abutment scour for historic flows } \\
\text { at sites in the Coastal Plain }\end{array}$ \\
\hline
\end{tabular}

Table B-10. Description of data on worksheets in the digital spreadsheets used to compute predicted abutment-scour depths for the Young equation (K. Young, K. Saffarinia, and J.S. Jones, Federal Highway Administration, unpub. data, 2002).

\section{Worksheet name}

README

Briefly describes the content of each worksheet within the spreadsheet.

\section{Description of data on worksheet}

Contains the data and calculations used to compute the predicted abutment-scour depths.

ENVELOPES Contains the South Carolina field data envelope and one-to-one line used in figures 1 and 2.

Fig 1 Compares the Young equation (K. Young, K. Saffarinia, and J.S. Jones, Federal Highway

Fig 2 Administration, unpub. data, 2002) with field observations. Compares the Young equation (K. Young, K. Saffarinia, and J.S. Jones, Federal Highway Administration, unpub. data, 2002) with the embankment-length envelope of the field data. 


\section{Selected References}

Laursen, E.M., 1963, An analysis of relief bridge scour: American Society of Civil Engineering Journal of Hydraulic Division, v. 92 , no. HY3.

Maryland State Highway Administration, 2006, Maryland State Highway Administration abutment scour program (ABSCOUR): Maryland State Highway Administration, version 7, build 1.03, compiled January 6, 2006.

Neill, C.R., ed., 1973, Guide to bridge hydraulics: Toronto, Ontario, Roads and Transportation Association of Canada, University of Toronto Press, 191 p.

Richardson, E.V., and Davis, S.R., 2001, Evaluating scour at bridges: Federal Highway Administration Hydraulic Engineering Circular No. 18, Publication FHWA-NHI-01-001, 378 p.

Shearman, J.O., 1990, User's manual for WSPRO-A computer model for water-surface profile computations: Federal Highway Administration, Report FHWA-IP-89-027, 175 p. 


\section{Appendix C}

Description of compiled data including WSPRO tube-velocity data, soil-boring data, selected abutment-scour data, and threshold velocity data. 


\section{WSPRO Tube-Velocity Data}

Tube-velocity data generated by the WSPRO model (Shearman, 1990) are tabulated in electronic spreadsheets. Data include selected hydraulic properties for the approach and bridge cross sections, as well as the velocity and area distributions generated by the equal-conveyance tube routine of the WSPRO model. The spreadsheet includes graphs of the velocity and area distributions, and approximate ground-surface cross sections for the bridge and approach sections for each bridge site. (The groundsurface cross sections were developed from the WSPRO tube data by using the average flow depth for each tube. There is some error associated with these approximate cross sections, but they provide a general understanding of the cross-section geometry.) The spreadsheet has five worksheets that contain hydraulic data or graphs. Table $\mathrm{C}-1$ lists the five worksheets and briefly describes the content of each worksheet. There are separate spreadsheets for the 100-year and maximum historic flow data titled "VELOCITY Q100" and "VELOCITY QHIS," respectively. These files can be viewed and(or) downloaded at the following link:

http://pubs.water.usgs.gov/ofr03-295/data.html\#Velocity

Table C-1. Description of data on worksheets in the digital spreadsheets compiling hydraulic data generated by the WSPRO model (Shearman, 1990).

\begin{tabular}{ll} 
Worksheet name & \multicolumn{1}{c}{ Description of data on worksheet } \\
\hline README & Briefly describes the content of each worksheet within the spreadsheet. \\
\hline APP VEL DATA & $\begin{array}{l}\text { Contains hydraulic and tube-velocity data generated by the WSPRO model (Shearman, 1990) } \\
\text { for the approach cross section. }\end{array}$ \\
BR VEL DATA & $\begin{array}{l}\text { Contains hydraulic and tube-velocity data generated by the WSPRO model (Shearman, 1990) } \\
\text { for the bridge cross section. }\end{array}$ \\
PLOT DATA & $\begin{array}{l}\text { Contains selected data used to develop graph on the "PLOTS" worksheet. } \\
\text { Contains graphs of the velocity and area distributions, and approximate ground-surface cross } \\
\text { sections for the bridge and approach sections. The graphs for a selected bridge site can be } \\
\text { viewed by entering the number in cell 'D1' that corresponds to the row number on the } \\
\text { "APP VEL DATA" worksheet in which the data for the bridge of interest resides. }\end{array}$ \\
\hline
\end{tabular}

\section{Soil-Boring Data}

Soil-boring data, obtained from the South Carolina Department of Transportation (SCDOT) bridge plans, have been tabulated in electronic spreadsheets. These data include the description, elevation, and thickness of each soil layer for a selected boring that was in close proximity to the observed abutment scour. The data also include the SCDOT plan numbers and station data to determine the relative position of the boring within the bridge opening. The file name for the spreadsheet is "SCDOT BORING DATA," and this file can be viewed and(or) downloaded at the following link:

http://pubs.water.usgs.gov/ofr03-295/data.html\#Boring

\section{Abutment-Scour Data}

Raw data for each observed abutment-scour hole have been compiled into a spreadsheet that contains the following categories: (1) site identification and basin characteristics; (2) field observations and an indicator of the flow condition that created the scour, which in all cases is unknown; (3) abutment data, which includes variables such as abutment type, embankment length, and blocked flow; (4) selected approach and bridge cross-section hydraulic properties; (5) sediment data, which includes 
variables such as the median grain size, soil descriptions as sand or clay, and critical velocity; and (6) limited pier data. Abutment and hydraulic data, such as the embankment length and blocked flow depth, are values generated from the WSPRO model (Shearman, 1990) and should be viewed as approximate values and not as the true values that created the observed scour. There are separate spreadsheets for the 100-year and maximum historic flow data titled "ABUTMENT Q100" and "ABUTMENT QHIS," respectively. These files can be viewed and(or) downloaded at the following link:

\section{http://pubs.water.usgs.gov/ofr03-295/data.html\#Abutment}

A brief description of the column data included in these spreadsheets is described in the following table:

Table C-2. Description of data in the Abutment-Scour Data spreadsheet.

Worksheet

column

Column heading

Description of data in worksheet column

letter

SITE AND BASIN INFORMATION

\begin{tabular}{|c|c|c|}
\hline A & COUNTY & County in which bridge resides. \\
\hline B & ROAD TYPE & $\begin{array}{l}\text { Road type including I - Interstate, US - United States Route, SC - South Carolina } \\
\text { Route, S - Secondary Road. }\end{array}$ \\
\hline $\mathrm{C}$ & ROAD NUMBER & Road number. \\
\hline $\mathrm{D}$ & STREAM & Stream name. \\
\hline $\mathrm{E}$ & $\begin{array}{c}\text { SOUTH CAROLINA } \\
\text { DEPARTMENT OF } \\
\text { TRANSPORTATION BRIDGE } \\
\text { NUMBER }\end{array}$ & Unique bridge number assigned by the South Carolina Department of Transportation. \\
\hline $\mathrm{F}$ & SLOPE OF STREAMBED & Slope of streambed determined from topographic map. \\
\hline G & DRAINAGE AREA & Drainage area at bridge. \\
\hline $\mathrm{H}$ & $\begin{array}{l}\text { PHYSIOGRAPHIC } \\
\text { PROVINCE }\end{array}$ & The South Carolina physiographic province in which the bridge is located. \\
\hline I & MULTIPLE BRIDGE & $\begin{array}{l}\text { Indicates if a bridge is associated with a multiple bridge crossing or not. A multiple } \\
\text { bridge typically consists of a main channel bridge with one or more relief bridge } \\
\text { openings at the same river crossing. }\end{array}$ \\
\hline $\mathrm{J}$ & BRIDGE LENGTH & The length of the bridge. \\
\hline
\end{tabular}

FIELD OBSERVATIONS

\begin{tabular}{ccl}
\hline K & LOCATION OF SCOUR & $\begin{array}{l}\text { Describes the location of the observed scour. The left and right abutments are } \\
\text { determined by an observer looking downstream; a swampy channel, in general, refers } \\
\text { to shorter bridges (240 feet or less) with a single large scour hole developing at the site } \\
\text { rather than individual left and(or) right abutment scour holes. }\end{array}$ \\
L $\quad$ OBSERVED SCOUR DEPTH & The depth of observed scour. \\
M & FLOW CONDITIONS & $\begin{array}{l}\text { Indicates what flow conditions created the observed scour. In all cases, the flow } \\
\text { condition is unknown. }\end{array}$ \\
\hline
\end{tabular}


Table C-2. Description of data in the Abutment-Scour Data spreadsheet. - Continued

\section{Worksheet}

column

letter

Column heading Description of data in worksheet column

ABUTMENT DATA

\begin{tabular}{|c|c|c|}
\hline $\mathrm{N}$ & $\begin{array}{c}\text { FLOW CONDITION FOR } \\
\text { ESTIMATING HYDRAULIC } \\
\text { CONDITIONS }\end{array}$ & $\begin{array}{l}\text { Indicates if the } 100 \text {-year flow (Q100) or the maximum historic flow (QHIS) was used to } \\
\text { estimate hydraulic conditions at a given site. }\end{array}$ \\
\hline $\mathrm{O}$ & ABUTMENT TYPE & Identification of abutment type as spill-through or vertical. \\
\hline $\mathrm{P}$ & $\begin{array}{l}\text { FLOW BLOCKED BY } \\
\text { EMBANKMENT }\end{array}$ & The approach flow obstructed by the embankment. \\
\hline Q & $\begin{array}{l}\text { AREA BLOCKED BY } \\
\text { EMBANKMENT }\end{array}$ & The approach flow area obstructed by the embankment. \\
\hline $\mathrm{R}$ & $\begin{array}{l}\text { EMBANKMENT } \\
\text { LENGTH }\end{array}$ & The road embankment length blocking flow. \\
\hline $\mathrm{S}$ & $\begin{array}{c}\text { AVERAGE DEPTH OF } \\
\text { FLOW BLOCKED BY } \\
\text { EMBANKMENT }\end{array}$ & The average depth of the approaching flow being blocked by the road embankment. \\
\hline $\mathrm{T}$ & EMBANKMENT SKEW & The skew of the road embankment to the approaching flow. \\
\hline
\end{tabular}

AVERAGE VELOCITY

U OF FLOW BLOCKED BY The average velocity of the approaching flow being blocked by the road embankment. EMBANKMENT

\begin{tabular}{|c|c|c|}
\hline \multicolumn{3}{|r|}{ FLOW CONTRACTION DATA } \\
\hline $\mathrm{V}$ & $\begin{array}{l}\text { GEOMETRIC } \\
\text { CONTRACTION RATIO }\end{array}$ & $\begin{array}{l}\text { The geometric-contraction ratio representing the contraction of flow width forced by the } \\
\text { bridge as determined by the WSPRO model (Shearman, 1990). }\end{array}$ \\
\hline $\mathrm{W}$ & $\begin{array}{l}\text { CONVEYANCE } \\
\text { CONTRACTION RATIO }\end{array}$ & $\begin{array}{l}\text { The conveyance-contraction ratio representing the contraction of flow conveyance } \\
\text { forced by the bridge as determined by the WSPRO model (Shearman, 1990). }\end{array}$ \\
\hline $\mathrm{X}$ & $\begin{array}{l}\text { BACKWATER CREATED BY } \\
\text { BRIDGE }\end{array}$ & The increase of the approaching water-surface elevation created by the bridge. \\
\hline \multicolumn{3}{|c|}{ APPROACH CROSS-SECTION HYDRAULIC DATA } \\
\hline $\mathrm{Y}$ & LEFT FLOOD-PLAIN FLOW & The flow on the left flood plain of the approach cross section. \\
\hline $\mathrm{Z}$ & LEFT FLOOD-PLAIN AREA & The flow area on the left flood plain of the approach cross section. \\
\hline AA & $\begin{array}{l}\text { LEFT FLOOD-PLAIN } \\
\text { AVERAGE FLOW DEPTH }\end{array}$ & The average flow depth on the left flood plain of the approach cross section. \\
\hline $\mathrm{AB}$ & $\begin{array}{l}\text { LEFT FLOOD-PLAIN TOP } \\
\text { WIDTH }\end{array}$ & The top width of the flow on the left flood plain of the approach cross section. \\
\hline
\end{tabular}


Table C-2. Description of data in the Abutment-Scour Data spreadsheet. - Continued

\begin{tabular}{c}
$\begin{array}{c}\text { Worksheet } \\
\text { column } \\
\text { letter }\end{array}$ Column heading $\quad$ Description of data in worksheet column \\
\hline
\end{tabular}

AC MAIN CHANNEL FLOW The flow in the main channel of the approach cross section.

AD MAIN CHANNEL AREA The flow area in the main channel of the approach cross section.

AE MAIN CHANNEL AVERAGE The average flow depth in the main channel of the approach cross section.
FLOW DEPTH

AF MAIN CHANNEL TOP
WIDTH

AG RIGHT FLOOD-PLAIN FLOW The flow on the right flood plain of the approach cross section.

AH RIGHT FLOOD-PLAIN AREA The flow area on the right flood plain of the approach cross section.

AI RIGHT FLOOD-PLAIN
AVERAGE FLOW DEPTH The average flow depth on the right flood plain of the approach cross section.

AJ RIGHT FLOOD-PLAIN TOP The top width of the flow on the right flood plain of the approach cross section.

BRIDGE CROSS-SECTION HYDRAULIC DATA

AK LEFT OVERBANK FLOW The flow on the left overbank of the bridge cross section.

AL LEFT OVERBANK AREA The flow area on the left overbank of the bridge cross section.

AM $\begin{gathered}\text { LEFT OVERBANK AVERAGE } \\ \text { FLOW DEPTH }\end{gathered}$
$\begin{gathered}\text { TEFT OVERBANK TOP } \\ \text { WIDTH }\end{gathered}$
AN The top width of the flow on the left overbank of the bridge cross section.

AP MAIN CHANNEL AREA The flow area in the main channel of the bridge cross section.

AQ MAIN CHANNEL AVERAGE
FLOW DEPTH

AR MAIN CHANNEL TOP The top width of the flow in the main channel of the bridge cross section.

AS RIGHT OVERBANK FLOW The flow on the right overbank of the bridge cross section.

AT RIGHT OVERBANK AREA The flow area on the right overbank of the bridge cross section.

RIGHT OVERBANK
AVERAGE FLOW DEPTH The average flow depth on the right overbank of the bridge cross section.

AV RIGHT OVERBANK TOP The top width of the flow on the right overbank of the bridge cross section. 
Table C-2. Description of data in the Abutment-Scour Data spreadsheet. - Continued

$\begin{aligned} & \text { Worksheet } \\ & \text { column } \\ & \text { letter }\end{aligned}$
Column heading
SEDIMENT DATA
During the initial data-collection phase of the study (Benedict, 2003), the analysis of grain-size distributions for sediment samples was
limited to grain sizes greater than or equal to $0.062 \mathrm{~mm}$. This is the breakpoint between the sand and silt/clay soils. For most Coastal Plain
sites, this analysis was adequate for defining the median grain size $\left(\mathrm{D}_{50}\right)$. However, this size occasionally was inadequate for clayey Pied-
mont soils where the $\mathrm{D}_{50}$ can be smaller than $0.062 \mathrm{~mm}$. At such sites, the $\mathrm{D}_{50}$ was assumed equal to $0.062 \mathrm{~mm}$, and clear-water contrac-
tion scour was computed for this grain size. In an attempt to better understand and define the clay content of Piedmont soils, second visits
were made to all Piedmont sites and a second grab sample was obtained and analyzed for the full range of grain size. In this table, the first
sample is referred to as sample 1 , and the second sample is called sample 2 .
GENERAL should be viewed with caution; the information can be used to determine if there is a dif-

AW DESCRIPTION OF

UNSCOURED

SURFACE SOILS

A subjective indicator of the general surface soils in the unscoured area near the observed ference between the surface soils and the soils at the bottom of the scour hole; following is a description of each class:

$$
\begin{aligned}
& \text { clay - a relatively cohesive soil } \\
& \text { sand - a sandy soil with relatively low cohesion } \\
& \text { layered - alternating layers of clay and sand } \\
& \text { mix - a mixture of sand and clay }
\end{aligned}
$$

\begin{tabular}{|c|c|c|}
\hline $\mathrm{AX}$ & $\begin{array}{c}\text { GENERAL } \\
\text { DESCRIPTION OF } \\
\text { SCOURED SOILS } \\
\text { AT BOTTOM } \\
\text { OF SCOUR HOLE }\end{array}$ & $\begin{array}{l}\text { A subjective indicator of the general soils at the low point of the scour hole; this informa- } \\
\text { tion is not necessarily an indicator of the measured grain size and should be viewed with } \\
\text { caution; the information can be used to determine if there is a difference between the } \\
\text { surface soils and the soils at the bottom of the scour hole; following is a description of } \\
\text { each class: } \\
\text { clay - a relatively cohesive soil } \\
\text { sand - a sandy soil with relatively low cohesion } \\
\text { layered - alternating layers of clay and sand } \\
\text { mix - a mixture of sand and clay }\end{array}$ \\
\hline
\end{tabular}

\begin{tabular}{|c|c|c|}
\hline AY & $\begin{array}{c}\text { MEDIAN } \\
\text { GRAIN SIZE OF } \\
\text { UNSCOURED SOILS } \\
\text { FROM SAMPLE } 1\end{array}$ & The median grain size for the unscoured surface soils determined from grab sample 1 . \\
\hline AZ & $\begin{array}{c}\text { CRITICAL VELOCITY } \\
\text { FOR D50 IN SAMPLE } 1 \\
\text { USING VANONI RELATION }\end{array}$ & $\begin{array}{l}\text { The critical velocity of the median grain size for sample } 1 \text { as estimated with the critical } \\
\text { velocity graph in Vanoni (1975). The mean value for the Vanoni curve was used. }\end{array}$ \\
\hline
\end{tabular}

CRITICAL VELOCITY

BA FOR D50 IN SAMPLE 1

USING HEC-18 EQUATION

The critical velocity of the median grain size for sample 1 as estimated with the critical velocity equation in HEC-18 (Richardson and Davis, 2001).

MEDIAN GRAIN SIZE OF
UNSCOURED SOILS
FROM SAMPLE 2 The median grain size for the unscoured surface soils determined from grab sample 2.

CRITICAL VELOCITY

BC FOR D50 IN SAMPLE 2

USING VANONI RELATION

The critical velocity of the median grain size for sample 2 as estimated with the critical velocity graph in Vanoni (1975). The mean value for the Vanoni curve was used.

\section{CRITICAL VELOCITY FOR}

BD D50 IN SAMPLE 2 USING

HEC-18 EQUATION
The critical velocity of the median grain size for sample 2 as estimated with the critical velocity equation in HEC-18 (Richardson and Davis, 2001). 
Table C-2. Description of data in the Abutment-Scour Data spreadsheet. - Continued

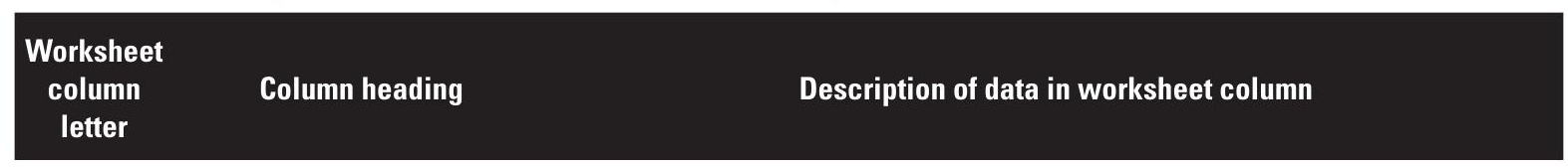

PIER DATA

IS THERE A PIER OR PILE

BE $\quad$ BENT LOCATED AT LOW

Indicates if there is a pier or pile bent located at the low point of the scour hole that may

POINT OF SCOUR HOLE? have contributed to the total scour at the abutment.

POINT OF SCOUR HOLE?

$\mathrm{BF}$

PIER SHAPE

The shape of the pier or pile bent that is located at the low point of the scour hole.

BG

PIER WIDTH

The width of the pier or pile bent that is located at the low point of the scour hole.

\section{Threshold Velocity Data}

A limited literature review identified various methods for estimating sediment threshold velocities including critical velocities and permissible velocities. Sediment threshold velocities were estimated for the South Carolina abutment-scour data by using 10 of the methods identified in the literature review. These estimates were tabulated into a digital spreadsheet along with the abutment-scour data described in the previous section. The file name for the spreadsheet is "THRESHOLD VELOCITIES" and can be viewed and(or) downloaded at http://pubs.water.usgs.gov/ofr03-295/data.html\#Threshold .

The findings of the limited literature review on threshold velocities and a comparison of critical and permissible velocities for selected predictive methods are included in Appendix D.

\section{Selected References}

Benedict, S.T., 2003, Clear-water abutment and contraction scour in the Coastal Plain and Piedmont Provinces of South Carolina, 1996-99: U.S. Geological Survey Water-Resources Investigations Report 03-4064, 137 p.

Richardson, E.V., and Davis, S.R., 2001, Evaluating scour at bridges: Federal Highway Administration Hydraulic Engineering Circular No. 18, Publication FHWA-NHI-01-001, 378 p.

Shearman, J.O., 1990, User's manual for WSPRO-A computer model for water-surface profile computations: Federal Highway Administration, Report FHWA-IP-89-027, 175 p.

Vanoni, V.A., 1975, Sedimentation engineering: American Society of Civil Engineers Task Committee for the preparation of the manual on sedimentation for the Sedimentation Committee of the Hydraulics Division (cited in Yang, 1996).

Yang, C.T., 1996, Sediment transport theory and practice: New York, McGraw-Hill, 396 p. 


\section{Appendix D}

A comparison of selected methods for estimating sediment threshold velocities. 


\title{
A Comparison of Selected Methods for Estimating Sediment Threshold Velocities
}

\author{
By Stephen T. Benedict ${ }^{1}$
}

\section{Introduction}

In the late 1990s, the U.S. Geological Survey (USGS), in cooperation with the South Carolina Department of Transportation (SCDOT), made 209 measurements of clear-water abutment-scour depth at 144 bridges in the Piedmont and Coastal Plain of South Carolina (Benedict, 2003). Data from this field investigation included scour depths, median grain sizes for soil samples, and hydraulic variables estimated from a water-surface profile model. Although limitations exist within the South Carolina data, the large number of measurements offers a valuable resource for assessing general trends of abutment scour.

Realizing the potential use of the South Carolina data, the USGS, in cooperation with the Federal Highway Administration (FHWA), initiated a study to assess the performance of selected abutment-scour equations (Benedict and others, 2006). Several of the predictive equations in that investigation used a threshold velocity (or critical velocity) as part of the algorithm for estimating abutment-scour depth. Methods for estimating threshold velocities varied between these equations highlighting the need to better understand the concept of threshold velocities. As an extension of the initial investigation (Benedict and others, 2006), the USGS, in cooperation with the FHWA, made a brief literature review of research on threshold velocity. Methods for estimating threshold velocities identified in the review were applied to the South Carolina data and compared to one another.

\section{Purpose and Scope}

The purpose of this report is to briefly describe (1) the findings of a limited literature review on threshold velocities, (2) the comparison of selected methods for estimating threshold velocities when applied to the South Carolina data (Benedict, 2003), and (3) the contents of a digital spreadsheet that contains the abutment-scour data from Benedict (2003) and the estimated threshold velocities in item 2. A description of and links to the digital spreadsheet are included in Appendix $\mathrm{C}$ of this report.

\section{Previous Investigations}

The investigation by Benedict and others (2006) used 209 observations of abutment scour in South Carolina (Benedict, 2003) to assess the performance of abutment-scour equations published in Hydraulic Engineering Circular 18 (HEC-18; Richardson and Davis, 2001), including the original Froehlich, the modified Froehlich, the Sturm, the Maryland, and the HIRE equations. Results from this assessment indicated that the equations could at times provide excessive overprediction, as well as underprediction, indicating a need for improved methods for predicting abutment-scour depth.

The Maryland equation (Richardson and Davis, 2001) incorporates the critical velocity in its algorithm, and it is possible to substitute a user defined value in the equation. Using the computer program ABSCOUR (Maryland State Highway Adminstration, 2006), the Maryland equation (Richardson and Davis, 2001) was applied to the South Carolina data using both the HEC-18 (Richardson and Davis, 2001) critical velocity equation and Neill's (1973) competent velocity curves. The results from this application (fig. D-1A) show that the HEC-18 critical velocity equation (Richardson and Davis, 2001) tends to produce excessive overprediction for the cohesive clayey soils of the Piedmont region of South Carolina, while producing frequent underprediction for the non-cohesive sandy soils of the Coastal Plain. The results using Neill's (1973) competent velocity (which tends to give larger estimates of threshold velocity than the HEC-18 equation) significantly reduced overprediction, but increased underprediction (fig. D-1B). 

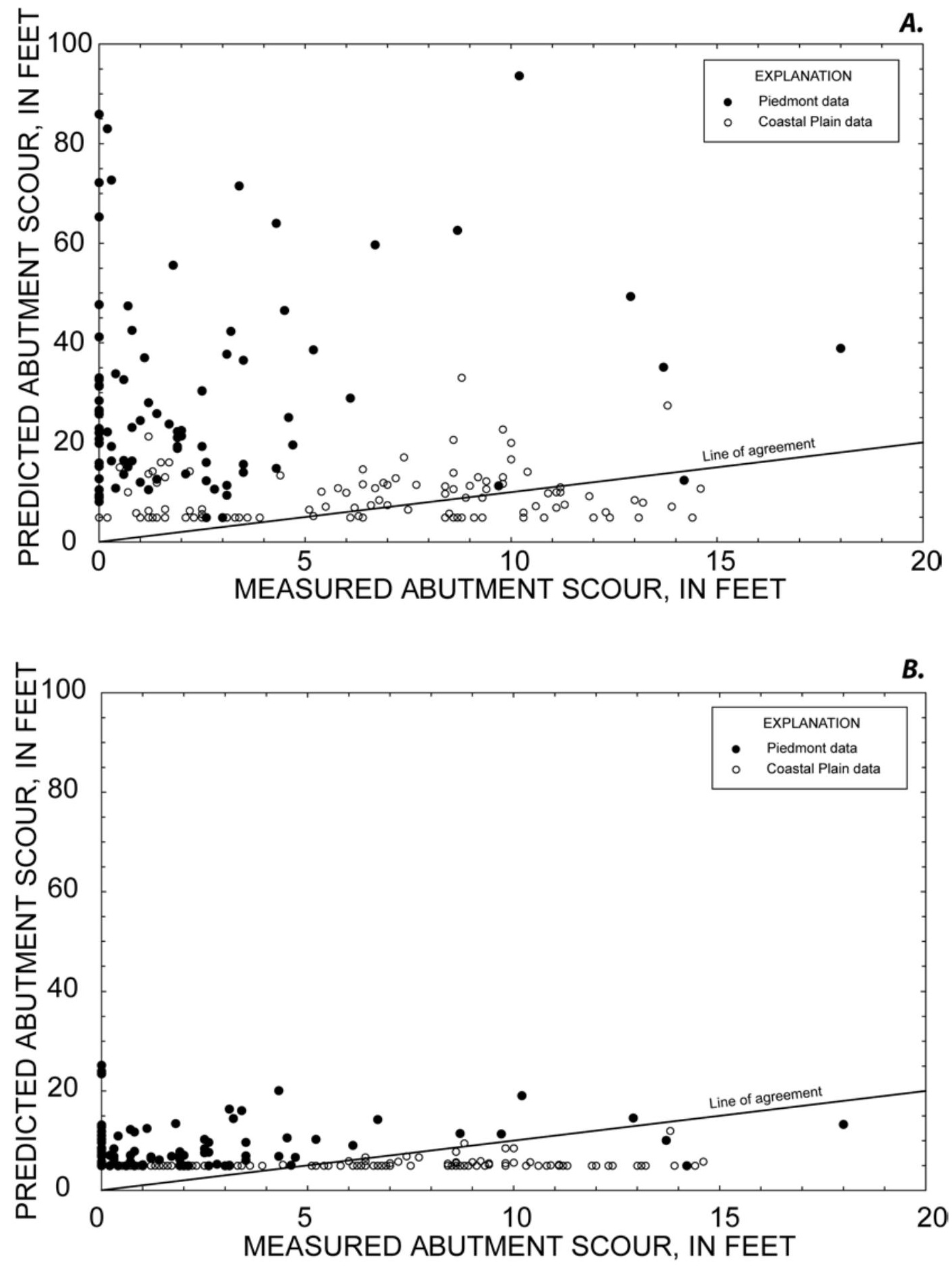

Figure D-1. Relation of measured to predicted abutment-scour depth computed with the ABSCOUR computer program (Maryland State Highway Administration, 2006) for selected sites in the Piedmont and Coastal Plain of South Carolina using the 100-year flow hydraulics, a safety factor of 1.3, and (A) the HEC-18 (Richardson and Davis, 2001) critical velocity equation and (B) Neill's (1973) competent velocity. 
Benedict and Caldwell (2006) observed similar trends when comparing measured and predicted scour using the clear-water contraction scour equation in HEC-18 that incorporates the HEC-18 critical velocity equation (Richardson and Davis, 2001) (fig. D-2). Figure D-2 indicates that use of the HEC-18 critical velocity equation (Richardson and Davis, 2001) for computing clear-water contraction scour gives excessive overprediction for the cohesive soils of the Piedmont and frequent underprediction for the sandy soils of the Coastal Plain. The trends of figures D-1 and D-2 indicated that predicted scour is sensitive to the selection of a threshold velocity highlighting the need to better understand this concept.

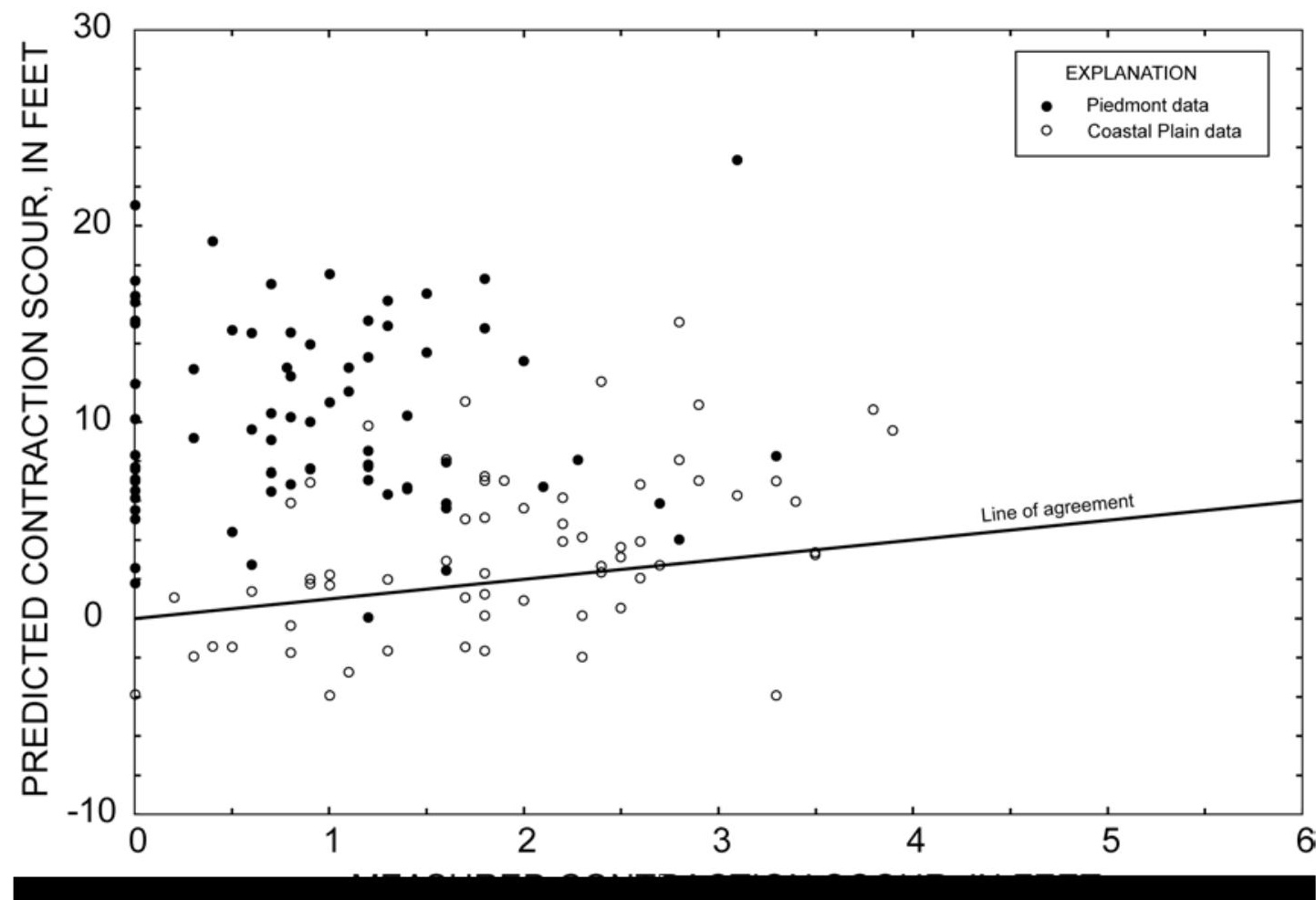

Figure D-2. Relation of measured clear-water contraction-scour depth to predicted contraction-scour depth for selected sites in the sandy soils of the Coastal Plain and the clayey soils of the Piedmont Physiographic Provinces of South Carolina. Predicted clear-water contraction scour was calculated with the HEC-18 equation (Richardson and Davis, 2001).

\section{Criteria for Defining Threshold Velocities}

The investigation of threshold velocities at which sediments will erode began many years ago. Much of the quest for understating this concept stemmed from the need to design earthen canals used for navigation, water supply, and irrigation. Graf (1971), in his short history of sediment transport, notes that D. Guglielmini (1655-1710) understood that scour will occur when the "scouring force" exceeds the "resistance of the soil." Graf (1971) also notes that P. DuBuat (1734-1809) is credited with some of the first laboratory investigations of threshold velocities, and DuBuat's writings on hydraulics and sediment transport were the most comprehensive of his day. The limited literature review indicates that investigators generally use two criteria to define threshold velocities for erosion: (1) the velocity at which the initiation of motion for loose-grain sediment begins (Vanoni, 1975) and (2) the maximum velocity that a natural soil can sustain without appreciable erosion (Fortier and Scobey, 1926). (For the purpose of this paper, criteria 1 will be called the critical velocity, and criteria 2 will be called the maximum permissible velocity.) Current practice often uses these two criteria to assess threshold conditions for soil erosion. If the average flow velocity across the sediment exceeds the critical or maximum permissible velocity, then erosion is assumed to occur. As erosion reduces the channel bed, the velocity across the bed will decrease and eventually reach the threshold velocity at which 
Table D-1. Threshold velocities observed by DuBuat (1786) (as published in Etcheverry (1915)).

[mm, millimeter; ft/s, feet per second; SG, specific gravity; _, no data]

\begin{tabular}{|c|c|c|c|c|c|c|c|}
\hline \multirow[b]{2}{*}{ Material } & \multirow{2}{*}{$\begin{array}{l}\text { Estimated } \\
\text { grain size } \\
\quad(\mathrm{mm})\end{array}$} & \multicolumn{3}{|c|}{$\begin{array}{l}\text { Bottom velocities } \\
\text { at which }\end{array}$} & \multicolumn{3}{|c|}{$\begin{array}{l}\text { Estimated average velocities } \\
\text { at which }{ }^{\mathrm{c}}\end{array}$} \\
\hline & & $\begin{array}{c}\text { trans- } \\
\text { portation } \\
\text { begins }^{\text {b }} \\
\text { (ft/s) }\end{array}$ & $\begin{array}{c}\text { material } \\
\text { is kept in } \\
\text { motion } \\
\text { (ft/s) }\end{array}$ & $\begin{array}{c}\text { silting } \\
\text { begins } \\
\text { (ft/s) }\end{array}$ & $\begin{array}{c}\text { trans- } \\
\text { portation } \\
\text { begins }{ }^{\text {b }} \\
\text { (ft/s) }\end{array}$ & $\begin{array}{c}\text { material } \\
\text { is kept in } \\
\text { motion } \\
\text { (ft/s) }\end{array}$ & $\begin{array}{c}\text { silting } \\
\text { begins } \\
\text { (ft/s) }\end{array}$ \\
\hline \multicolumn{8}{|c|}{ Laboratory observations } \\
\hline $\begin{array}{l}\text { Dark clay fit for pottery } \\
\qquad(\mathrm{SG}=2.64)\end{array}$ & 0.001 & 0.35 & 0.27 & - & 0.50 & 0.39 & 一 \\
\hline $\begin{array}{l}\text { Coarse yellow sand } \\
\qquad(\mathrm{SG}=3.36)\end{array}$ & 0.5 & 1.07 & 0.71 & 0.62 & 1.53 & 1.01 & 0.89 \\
\hline $\begin{array}{l}\text { Small gravel size of anise } \\
\text { seed }(\mathrm{SG}=2.55)\end{array}$ & 1 & 0.53 & 0.35 & 0.27 & 0.76 & 0.50 & 0.39 \\
\hline $\begin{array}{l}\text { Gravel size of pea } \\
\quad(\mathrm{SG}=2.55)\end{array}$ & 5 & 0.71 & 0.62 & 0.53 & 1.01 & 0.89 & 0.76 \\
\hline $\begin{array}{l}\text { Gravel size of large bean } \\
\quad(\mathrm{SG}=2.55)\end{array}$ & 10 & 1.56 & 1.07 & 0.71 & 2.23 & 1.53 & 1.01 \\
\hline $\begin{array}{l}\text { Round pebbles } 1 \text { inch or } \\
\text { more }(S G=2.61)\end{array}$ & 25 & 3.20 & 2.14 & 1.56 & 4.57 & 3.06 & 2.23 \\
\hline $\begin{array}{l}\text { Angular flint, egg size } \\
\qquad(\mathrm{SG}=2.25)\end{array}$ & 50 & 4.00 & 3.20 & 2.14 & 5.71 & 4.57 & 3.06 \\
\hline \multicolumn{8}{|c|}{ Field observation on the Loire River in France } \\
\hline Gravel 0.04 inch diameter & 1 & 1.64 & - & - & 2.34 & - & - \\
\hline Gravel 0.16 inch diameter & 4 & 3.28 & - & - & 4.69 & - & 一 \\
\hline Gravel 0.39 inch diameter & 10 & 4.92 & - & - & 7.03 & - & - \\
\hline Gravel 0.67 inch diameter & 17 & 6.56 & - & - & 9.37 & - & - \\
\hline
\end{tabular}

${ }^{\mathrm{a}}$ Grain size was estimated based on descriptions given by DuBuat (1786) as described in Etcheverry (1915).

bAccording to Etcheverry (1915), the velocity as observed in DuBuat's (1786) laboratory experiments represents the threshold for transporting loose-grain material and, thus, more closely approximates the critical velocity rather than the maximum permissible velocity. However, DuBuat's field observations on the Loire River in France appear to be comparable to the maximum permissible velocity.

${ }^{c}$ The average velocity was estimated assuming the bottom velocity to be approximately 70 percent of the average velocity as noted by Etcheverry (1915). 
on the Loire River in France (table D-1). Figure D-4 shows DuBuat's (1786) critical velocities in relation to Vanoni's (1975) critical velocity curve and Fortier and Scobey's (1926) maximum permissible velocities. DuBuat's (1768) laboratory data generally follow the trend of the laboratory data presented by Vanoni (1975), and interestingly, DuBuat's field observations are more in line with the field observations of Fortier and Scobey (1926). This supports the concept that the threshold velocities for loosegrain sediments in the laboratory setting can be significantly different from those found in the field.

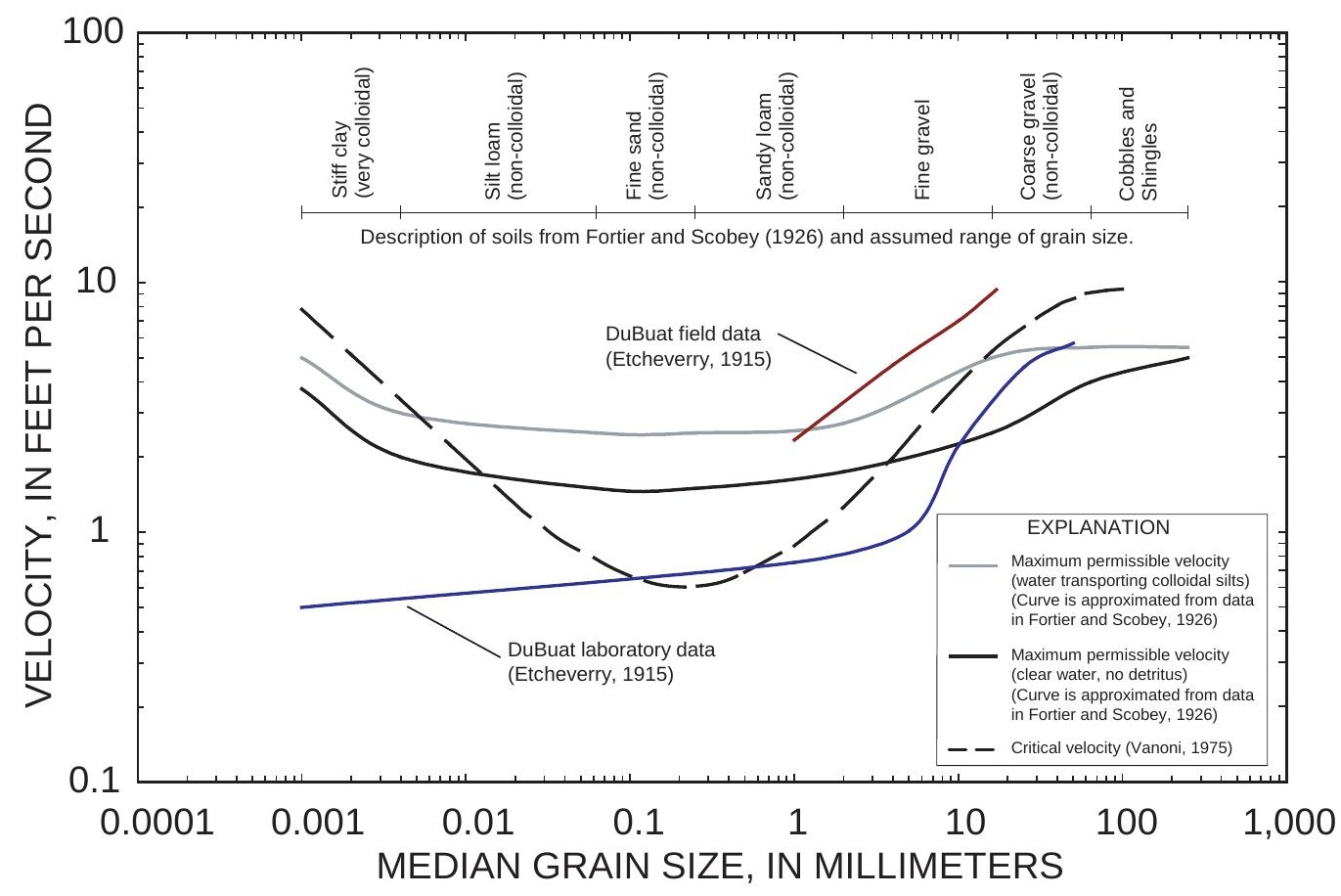

Figure D-4. DuBuat's (1786) threshold velocity data (as published by Etcheverry (1915)) in relation to Vanoni (1975) and Fortier and Scobey (1926).

\section{Laursen (1963) and Richardson and others (2001)}

Laursen (1963) developed an equation for estimating clear-water contraction scour for loose-grain sediments at a relief bridge. The equation assumes continuity of flow between the contracted and un-contracted sections and a long contraction where flow is fully developed. Making some simplifying assumptions for critical tractive force (four times the grain size in feet) and the use of Manning's equation to estimate the slope and Strickler's (1923) estimate for Manning's roughness coefficient based on sediment size, Laursen (1963) proposed the following equation:

$$
V_{c}=10.8 D_{50}{ }^{1 / 3} y_{1}{ }^{1 / 6},
$$

where

$\begin{aligned} V_{c} & \text { is the critical velocity, in feet per second; } \\ D_{50} & \text { is the median grain size, in feet; and } \\ y_{1} & \text { is the depth of flow prior to scour, in feet. }\end{aligned}$ 
The fourth edition of Hydraulic Engineering Circular No. 18 (Richardson and Davis, 2001) presents a slightly modified version of equation 1 , as follows:

$$
V_{c}=11.25 D_{m}^{1 / 3} y_{1}^{1 / 6},
$$

where

$$
\begin{aligned}
& D_{m} \text { is } 1.25 D_{50} \text {, in feet, and } \\
& V_{c}, D_{50} \text {, and } y_{1} \text { are defined in equation } 1 .
\end{aligned}
$$

The modification of the coefficient in equation 2 reflects the changes in Laursen's derivation when using $D_{m}$ rather than $D_{50}$ as recommended in Richardson and others (2001). It should be kept in mind that equations 1 and 2 were derived for non-cohesive soils and will underpredict critical velocity if applied to cohesive soils.

Using a similar approach to that of Laursen (1963), Richardson and others (2001) developed a more general version of equation 1 that allows for the incorporation of assumptions other than those used by Laursen. A detailed derivation of the equation is presented in Richardson and others (2001) and the final equation is as follows:

where

$$
V_{c}=\frac{1.49 K_{s}^{1 / 2}\left(S_{s}-1\right)^{1 / 2} D_{50}{ }^{1 / 2} y_{1}^{1 / 6}}{n}
$$

$K_{s}$ is the Shields (1935) parameter (also called the dimensionless critical shear stress),

$S_{s}$ is the specific gravity of the sediment,

$n$ is Manning's roughness coefficient, and other variables are defined in equation 1.

With the general equation above (eq. 3), it is possible to substitute various relations for estimating Manning's roughness coefficient to obtain a simplified equation for estimating $V_{c}$. Strickler's (1923) approximation of Manning's roughness coefficient,

$$
n=0.034 D_{50}^{1 / 6},
$$

where $n$ and $D_{50}$ are defined in equations 1 and 3, was the relation originally used by Laursen (1963). It is also possible to use Blodgett's (1986) relation for Manning's roughness coefficient based on field observations for sand channels,

$$
n=0.0152 y_{1}^{1 / 6},
$$

where $n$ and $\mathrm{y}_{1}$ are defined in equations 1 and 3. If the specific gravity of the sediment is assumed to be 2.65 and Strickler's (1923) relation (eq. 4) for Manning's roughness coefficient is substituted, then equation 3 reduces to the following:

$$
V_{c}=56.29 K_{s}^{1 / 2} D_{50}{ }^{1 / 3} y_{1}{ }^{1 / 6},
$$

where variables are defined in equations 1 and 3. Likewise, if the specific gravity of the sediment is assumed to be 2.65 and Blodgett's relation (eq. 5) for Manning's roughness coefficient is substituted, then equation 3 reduces to the following:

$$
V_{c}=125.92 K_{s}{ }^{1 / 2} D_{50}^{1 / 2},
$$

where variables are defined in equations 1 and 3. 
The Shields (1935) parameter in equations 3, 6, and 7 can be estimated by calculating the boundary Reynolds number and using the Shields diagram (fig. D-5). The boundary Reynolds number is defined as,

$$
R_{*}=\frac{U_{*} D_{s}}{v},
$$

where

$R_{*} \quad$ is the boundary Reynolds number;

$U_{*} \quad$ is the boundary shear velocity, in feet per second, and is equal to

$$
\sqrt{\frac{\gamma y_{1} S}{\rho}}
$$

where

$\gamma$ is the fluid specific weight, in pounds per cubic foot;

$S$ is the energy slope, in feet per feet;

$\rho$ is the fluid density, in slugs per cubic foot; and

$y_{1}$ is defined in equation 1 .

$D_{\mathrm{s}}$ is the sediment size, in feet; and

$v$ is the kinematic viscosity, in square feet per second.

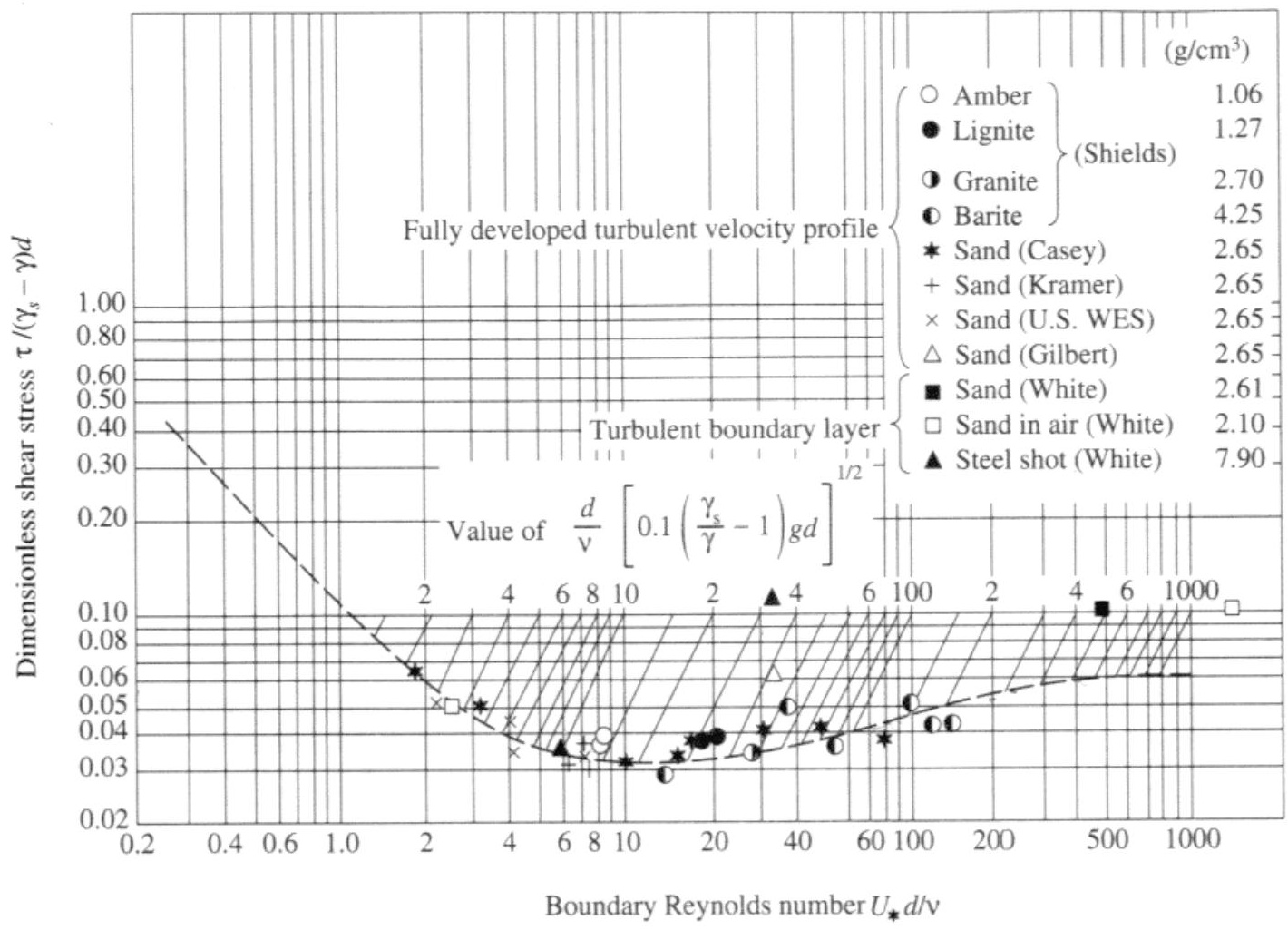

Figure D-5. The Shields diagram for the critical shear stress of non-cohesive sediments (based on Vanoni (1975) as shown in Yang (1996)). 
Assuming the temperature of water to be 60 degrees Fahrenheit, $\gamma$ is equal to 62.4 pounds per cubic foot, $\rho$ is equal to 1.94 slugs per cubic foot, and $v$ is equal to $1.22 \times 10^{-5}$ square feet per second. Using these values and assuming that $D_{\mathrm{s}}$ is equal to the median grain size, equation 8 can be simplified to the following:

$$
R_{*}=464870 D_{50} \sqrt{y_{1} S},
$$

where all variables are defined in equations 1 and 8. Having an estimate of the boundary Reynolds number, the Shields parameter can be estimated from the Shields diagram (fig. D-5) or by the following transformed equations developed from the Shields diagram curve.

Equation for the Shields diagram

- For $0.25 \leq \mathrm{R}_{*}<2.0$

$K_{\mathrm{s}}=0.1175 \mathrm{R}_{*}-0.9897$

- For $2 \leq \mathrm{R}_{*}<10$

$$
K_{\mathrm{s}}=-6.0 \times 10^{-6} \mathrm{R}_{*}^{5}+0.0002 \mathrm{R}_{*}^{4}-0.0029 \mathrm{R}_{*}^{3}+0.02 \mathrm{R}_{*}^{2}-0.0712 \mathrm{R}_{*}+0.1425
$$

- For $10 \leq \mathrm{R}_{*}<400$

$$
K_{s}=-1.0 \times 10^{-12} \mathrm{R}_{*}^{4}+1.0 \times 10^{-9} \mathrm{R}_{*}^{3}-7.0 \times 10^{-7} \mathrm{R}_{*}^{2}+0.0002 R_{*}+0.0303
$$

where $K_{s}$ and $\mathrm{R}_{*}$ are defined in equations 3 and 8 .

\section{Vanoni (1975)}

The American Society of Civil Engineers Sedimentation Task Committee (Vanoni, 1975) compiled laboratory data (largely based on the work of Hjulstrom (1935)) and developed critical-velocity curves (fig. D-6) representing the lower limit, average, and upper limit of critical velocities for quartz sediment of selected size. The lower and upper limit curves represent the scatter within the data and indicate the discrepancies that exist within the selected laboratory investigations. Vanoni (1975) states that for grain sizes greater than $0.01 \mathrm{~mm}$, Hjulstrom (1935) determined critical velocities from selected laboratory investigations. For grain sizes less than $0.01 \mathrm{~mm}$, Hjulstrom (1935) used field data from Fortier and Scobey (1926) to estimate critical velocities for cohesive materials.

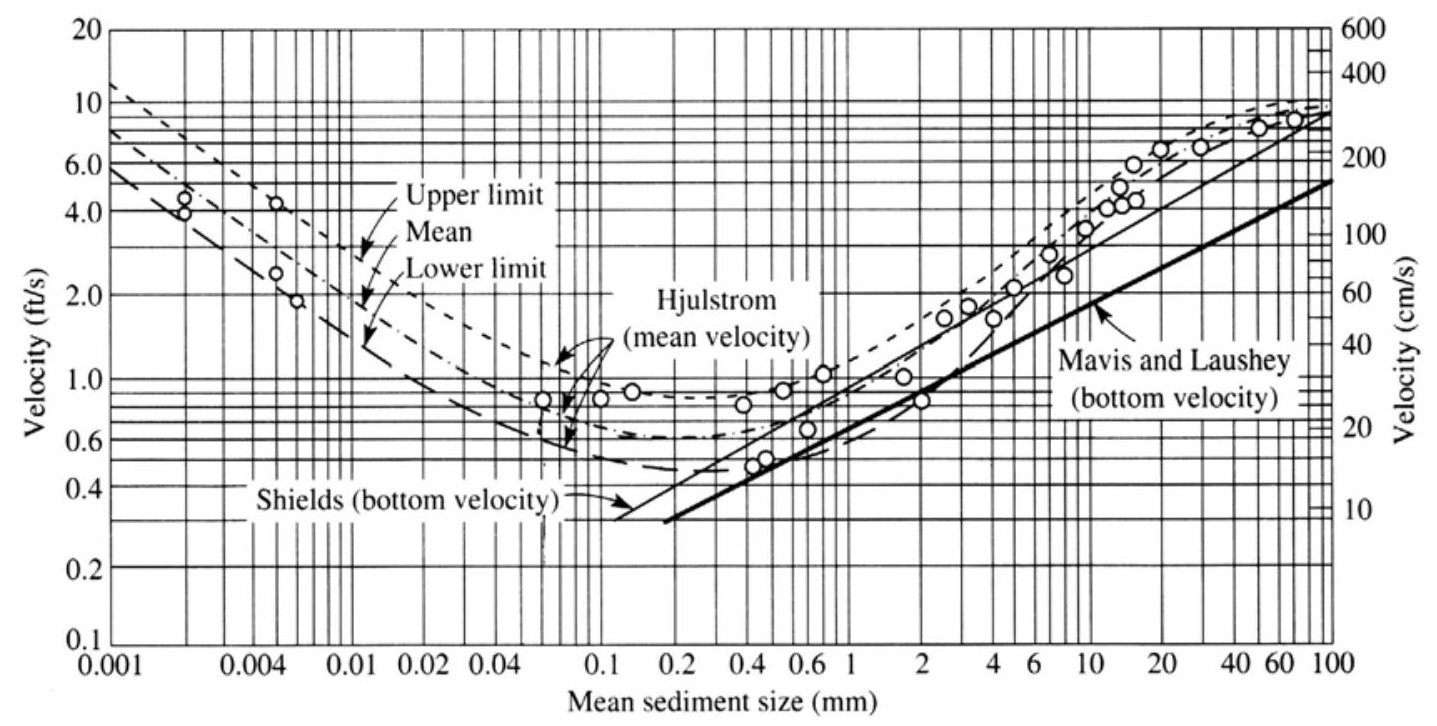

Figure D-6. Critical velocity curves developed from laboratory and limited field data (Vanoni (1975) as shown in Yang (1996)). 
The curves in figure D-6 have been transformed into equations and are presented below.

Lower Limit Curve Equation

- For $0.001 \mathrm{~mm} \leq D_{50 \mathrm{~mm}}<0.04 \mathrm{~mm}$

$V_{\mathrm{c}}=0.1028\left(D_{50}\right)^{-0.5828}$

- For $0.04 \mathrm{~mm}<D_{50 \mathrm{~mm}} \leq 0.4 \mathrm{~mm}$

$V_{\mathrm{c}}=26.24\left(D_{50 \mathrm{~mm}}\right)^{4}-38.862\left(D_{50 \mathrm{~mm}}\right)^{3}+21.019\left(D_{50 \mathrm{~mm}}\right)^{2}-4.8791\left(D_{50 \mathrm{~mm}}\right)+0.85$

- For $0.4 \mathrm{~mm}<D_{50 \mathrm{~mm}}$

$V_{\mathrm{c}}=0.000003\left(D_{50 \mathrm{~mm}}\right)^{4}-0.0003\left(D_{50 \mathrm{~mm}}\right)^{3}+0.0057\left(D_{50 \mathrm{~mm}}\right)^{2}+0.2645\left(D_{50 \mathrm{~mm}}\right)+0.337$

where $D_{50 \mathrm{~mm}}$ is the median grain size, in mm; and $V_{c}$ is defined in equation 1.

Average Curve Equation

- For $0.001 \mathrm{~mm} \leq D_{50 \mathrm{~mm}}<0.04 \mathrm{~mm}$

$$
V_{\mathrm{c}}=0.1241\left(D_{50 \mathrm{~mm}}\right)^{-0.5994}
$$

- For $0.04 \mathrm{~mm}<D_{50 \mathrm{~mm}} \leq 0.2 \mathrm{~mm}$

$$
V_{\mathrm{c}}=-163.69\left(D_{50 \mathrm{~mm}}\right)^{3}+78.571\left(D_{50 \mathrm{~mm}}\right)^{2}-12.631\left(D_{50 \mathrm{~mm}}\right)+1.2893
$$

- For $0.2 \mathrm{~mm}<\mathrm{D}_{50 \mathrm{~mm}}$

$$
V_{\mathrm{c}}=-0.0038\left(\mathrm{D}_{50 \mathrm{~mm}}\right)^{2}+0.388\left(\mathrm{D}_{50 \mathrm{~mm}}\right)+0.4999
$$

where $V_{c}$ and $D_{50 \mathrm{~mm}}$ are defined above.

\section{Upper Limit Curve Equation}

- For $0.001 \mathrm{~mm} \leq D_{50 \mathrm{~mm}}<0.06 \mathrm{~mm}$

$$
V_{\mathrm{c}}=0.2074\left(D_{50 \mathrm{~mm}}\right)^{-0.5784}
$$

- For $0.06 \mathrm{~mm}<D_{50 \mathrm{~mm}} \leq 0.6 \mathrm{~mm}$

$$
V_{\mathrm{c}}=6.3348\left(D_{50 \mathrm{~mm}}\right)^{4}-15.28\left(D_{50 \mathrm{~mm}}\right)^{3}+13.034\left(D_{50 \mathrm{~mm}}\right)^{2}-4.1874\left(D_{50 \mathrm{~mm}}\right)+1.2988
$$

- For $0.6 \mathrm{~mm}<D_{50 \mathrm{~mm}}$

$$
V_{\mathrm{c}}=0.0000004\left(D_{50 \mathrm{~mm}}\right)^{4}+0.0001\left(D_{50 \mathrm{~mm}}\right)^{3}-0.0099\left(D_{50 \mathrm{~mm}}\right)^{2}+0.4671\left(D_{50 \mathrm{~mm}}\right)+0.7405
$$

where $V_{c}$ and $D_{50 \mathrm{~mm}}$ are defined above.

The data used for developing the curves in figure D-6 represent critical velocities for flow depths of approximately $3 \mathrm{ft}$. Because critical velocity can vary with flow depth, it is important to adjust the critical velocities estimated from the Vanoni (1975) curves. Yang (1996) recommends a correction factor based on the ratio of hydraulic radius raised to the 1/6 power. Assuming that the flow depth in a natural channel approximates the hydraulic radius, the following depth correction coefficient can be used to correct $V_{c}$ obtained from figure D-6 or equations 11 through 13.

$$
k_{\text {depth }}=\left(\frac{y_{1}}{3}\right)^{1 / 6}
$$

where $k_{\text {depth }}$ is the depth correction coefficient, and $y_{1}$ is defined in equation 1.

Note that the 3 in the denominator represents the approximated $3 \mathrm{ft}$ flow depth for the Vanoni (1975) curves. 


\section{Selected Methods for Estimating Maximum Permissible Velocities}

Maximum permissible velocity is defined as the maximum velocity that a natural sediment can sustain without appreciable erosion (Fortier and Scobey, 1926). Methods for estimating maximum permissible velocities are largely derived from field observations, with much of the data collected in irrigation canals. Data typically are grouped into general soil categories, and there is often a range of maximum permissible velocities for each group. Where field data are limited, some researchers have relied on critical velocity data to modify or extend the field data.

With regard to maximum permissible velocity, Lane (1955) noted in his extensive work on channel stability that there were only "three sources of systematic data available (as of 1952) on permissible velocities in canals." These included Etcheverry (1915), Fortier and Scobey (1926), and an investigation in Russia (Bureau of the Methodology of the Hydro-Energo Plan, 1936). The limited literature review conducted for this paper identified several additional sources of maximum permissible velocity data that have been published since Lane's (1955) work (and there are undoubtedly other works not listed here). These include the works of Neill (1973) and Keown and others (1977). Additionally, Fischenich (2001) tabulated maximum permissible velocity data from various investigations (including citations from recent studies) and provides an insightful summary on threshold velocities. Following is a summary of the findings from Etcheverry (1915), Fortier and Scobey (1926), the Bureau of the Methodology of the Hydro-Energo Plan (1936), Neill (1973), and Keown and others (1977).

\section{Etcheverry (1915) and Fortier and Scobey (1926)}

The design and maintenance of irrigation canals have been an important engineering discipline for the agricultural industry. In the 1800s and early 1900s, the use of earthen canals was of particular importance to the development and growth of the arid regions of the western United States. In the early 1900s, much attention was given to design criteria for earthen canals, and the concept of the maximum permissible velocity became an important component of those criteria. According to Lane (1955), there was no extensive investigation of maximum permissible velocities prior to the work of Etcheverry (1915) and Fortier and Scobey (1926). The maximum permissible velocities presented by Etcheverry (1915) and Fortier and Scobey (1926) are largely based on the observations and judgment of field engineers experienced with the design and maintenance of earthen irrigation canals. The work of Fortier and Scobey (1926) was commissioned by the American Society of Civil Engineer's Special Committee on Irrigation Hydraulics and involved an extensive survey of the experienced irrigation engineers of that day. The data were tabulated into ranges of maximum permissible velocities for general soil groups (including cohesive soils) and for selected flow conditions. Recommended values for maximum permissible velocities by Etcheverry (1915) and Fortier and Scobey (1926) are presented in tables D-2 and D-3, respectively, and these values should be adjusted for flow depth by using equation 14 . Because the maximum permissible velocities in tables D-2 and D-3 are listed by general soil groups with a range of velocities, the selection of an appropriate maximum permissible velocity is somewhat subjective. Although much of the early work associated with defining maximum permissible velocities deals with the design of earthen irrigation canals, the data also can provide insight into other disciplines of engineering including bridge scour (Neill, 1973; Chang and Davis, 1999). 
Table D-2. Maximum permissible velocities from Etcheverry (1915).

\begin{tabular}{lcc}
\hline & & \\
& & \\
\multicolumn{1}{c}{ Original material excavated for canal } & Lower limit & Upper limit \\
\cline { 2 - 3 } & & \\
\hline Very light pure sand of quicksand character & 0.75 & 1.00 \\
Very light loose sand & 1.00 & 1.50 \\
Coarse sand or light sandy soil & 1.50 & 2.00 \\
Average sandy soil & 2.00 & 2.50 \\
Sandy loam & 2.50 & 2.75 \\
Average loam, alluvial soil, volcanic ash & 2.75 & 3.00 \\
Firm loam, clay loam & 3.00 & 3.75 \\
Stiff clay soil, ordinary gravel soil & 4.00 & 5.00 \\
Coarse gravel, cobbles, and shingles & 5.00 & 6.00 \\
Conglomerate, cemented gravel, soft slate, tough hard pan, & 6.00 & 8.00 \\
$\quad$ soft sedimentary rock & & \\
Hard rock & 10.00 & 15.00 \\
Concrete & 15.00 & 20.00 \\
\hline
\end{tabular}

Table D-3. Maximum permissible velocities from Fortier and Scobey (1926).

\begin{tabular}{llc}
\hline & \multicolumn{2}{c}{$\begin{array}{c}\text { Velocity, in feet per second, after } \\
\text { aging of canal carrying }\end{array}$} \\
\cline { 2 - 3 } \multicolumn{1}{c}{ Original material excavated for canal } & clear water, no & $\begin{array}{c}\text { water } \\
\text { transporting } \\
\text { colloidal silts }\end{array}$ \\
\hline Fine sand (non-colloidal) & 1.50 & 2.50 \\
Sandy loam (non-colloidal) & 1.75 & 2.50 \\
Silt loam (non-colloidal) & 2.00 & 3.00 \\
Alluvial silts when non-colloidal & 2.00 & 3.50 \\
Ordinary firm loam & 2.50 & 3.50 \\
Volcanic ash & 2.50 & 3.50 \\
Fine gravel & 2.50 & 5.00 \\
Stiff clay (very colloidal) & 3.75 & 5.00 \\
Graded loam to cobbles, when non-colloidal & 3.75 & 5.00 \\
Alluvial silts when colloidal & 3.75 & 5.00 \\
Graded silt to cobble, when colloidal & 4.00 & 5.50 \\
Coarse gravel (non-colloidal) & 4.00 & 6.00 \\
Cobbles and shingles & 5.00 & 5.50 \\
Shales and hard pans & 6.00 & 6.00 \\
\hline
\end{tabular}




\section{Russian Bureau of the Methodology of the Hydro-Energo Plan (1936)}

Lane (1955) cites an investigation of maximum permissible velocities described in the Russian publication, "Bureau of the Methodology of the Hydro-Energo Plan" (1936). This study provided maximum permissible velocities for non-cohesive and cohesive soils and determined that the compaction of the soil affected the ability of a soil to resist erosion. Table D-4 provides maximum permissible velocities for specific grain sizes of non-cohesive sediments. Table D-5 provides maximum permissible velocities for general classes of cohesive sediments with varying degrees of soil compaction. Because the maximum permissible velocities in table D-5 are listed by general soil groups with a range of soil compaction, the selection of an appropriate maximum permissible velocity from this table is somewhat subjective. The velocities in tables D-4 and D-5 should be adjusted for flow depth by using equation 14. (Note: Chow (1959) presents the data in table D-5 in graphical format, which is instructive in displaying the general trends of the Russian data.)

Table D-4. Maximum permissible velocities for noncohesive soils from Russian investigation (Bureau of the Methodology of the Hydro-Energo Plan (1936) as cited by Lane (1955)).

\begin{tabular}{lcc}
\hline \multirow{2}{*}{ Material } & \multicolumn{1}{c}{$\begin{array}{c}\text { Particle } \\
\text { diameter, } \\
\text { in millimeters }\end{array}$} & $\begin{array}{c}\text { Mean } \\
\text { velocity, in feet } \\
\text { per second }\end{array}$ \\
\hline Silt & 0.0055 & 0.49 \\
\cline { 2 - 3 } Fine sand & .05 & .66 \\
\cline { 2 - 3 } Medium sand & .25 & .98 \\
\cline { 2 - 3 } Coarse sand & 1.00 & 1.80 \\
\cline { 2 - 3 } Fine gravel & 2.50 & 2.13 \\
\cline { 2 - 3 } Medium gravel & 5.00 & 2.62 \\
\cline { 2 - 3 } Coarse gravel & 10.00 & 3.28 \\
\cline { 2 - 3 } Fine pebbles & 15.00 & 3.94 \\
\cline { 2 - 3 } Medium pebbles & 25.0 & 4.59 \\
\cline { 2 - 3 } Coarse pebbles & 40.0 & 5.91 \\
\cline { 2 - 3 } Large pebbles & 75.0 & 7.87 \\
Large pebbles & 100.0 & 10.86 \\
\cline { 2 - 3 } Large pebbles & 150.0 & 12.80 \\
\hline
\end{tabular}

Table D-5. Maximum permissible velocities for cohesive soils from Russian investigation (Bureau of the Methodology of the Hydro-Energo Plan (1936) as cited by Lane (1955)).

\begin{tabular}{lcccc}
\hline & \multicolumn{4}{c}{ Compaction of bed } \\
\cline { 2 - 5 } $\begin{array}{l}\text { Principle cohesive } \\
\text { material of bed }\end{array}$ & Loose & Fairly compacted & Compacted & Very compacted \\
\cline { 2 - 5 } & $\mathbf{2 . 0}$ to $\mathbf{1 . 2}$ & $\mathbf{1 . 2}$ to $\mathbf{0 . 6}$ & $\mathbf{0 . 6}$ to $\mathbf{0 . 3}$ & $\mathbf{0 . 3}$ to $\mathbf{0 . 2}$ \\
\cline { 2 - 5 } & $\begin{array}{c}\text { Velocity, in feet } \\
\text { per second }\end{array}$ & $\begin{array}{c}\text { Velocity, in feet } \\
\text { per second }\end{array}$ & $\begin{array}{c}\text { Velocity, in feet } \\
\text { per second }\end{array}$ & $\begin{array}{c}\text { Velocity, in feet } \\
\text { per second }\end{array}$ \\
\hline Sandy clays & 1.48 & 2.95 & 4.26 & 5.90 \\
Heavy clayey soils & 1.31 & 2.79 & 4.10 & 5.58 \\
Clays & 1.15 & 2.62 & 3.94 & 5.41 \\
Lean clayey soils & 1.05 & 2.30 & 3.44 & 4.43 \\
\hline
\end{tabular}




\section{Neill (1973)}

Neill (1973) presented a family of curves (fig. D-7) for estimating competent velocities for non-cohesive sediments for varying flow depths and with grain sizes ranging from 0.3 to $300 \mathrm{~mm}$. Neill defines the competent velocity as the flow velocity just competent to move the bed material. Neill (1973) uses a combination of field data and laboratory data to develop his family of curves, and his competent velocity could be considered a hybrid between critical and maximum permissible velocities. To develop the family of curves, Neill (1973) used a critical velocity equation very similar to the HEC-18 (Richardson and Davis, 2001) equation (eq. 2) to estimate the competent velocity for grain sizes greater than about $30 \mathrm{~mm}$. For a grain size of $0.3 \mathrm{~mm}$, Neill (1973) assumes that a regime theory equation for stable channels in sand will be appropriate for estimating the competent velocity. (Regime theory equations are design equations developed from field data collected in the stable, fine sediment canals of Pakistan (Mahmood and Shen, 1971).) The selected regime theory equation is as follows:

$$
\frac{V_{m}}{y_{1}}=1.0,
$$

where $V_{m}$ is the mean velocity for a stable sand channel, in feet per second, and $y_{l}$ is defined in equation 1 . Having defined competent velocities for a grain size of $0.3 \mathrm{~mm}$ and for grain sizes greater than $30 \mathrm{~mm}$, transition curves were hand drawn for grain sizes between 0.3 and $30 \mathrm{~mm}$. Neill (1973) states that the transition curves "are not based on experimental data" and that "the entire diagram requires extensive testing in practice" and should be "treated with reservations."

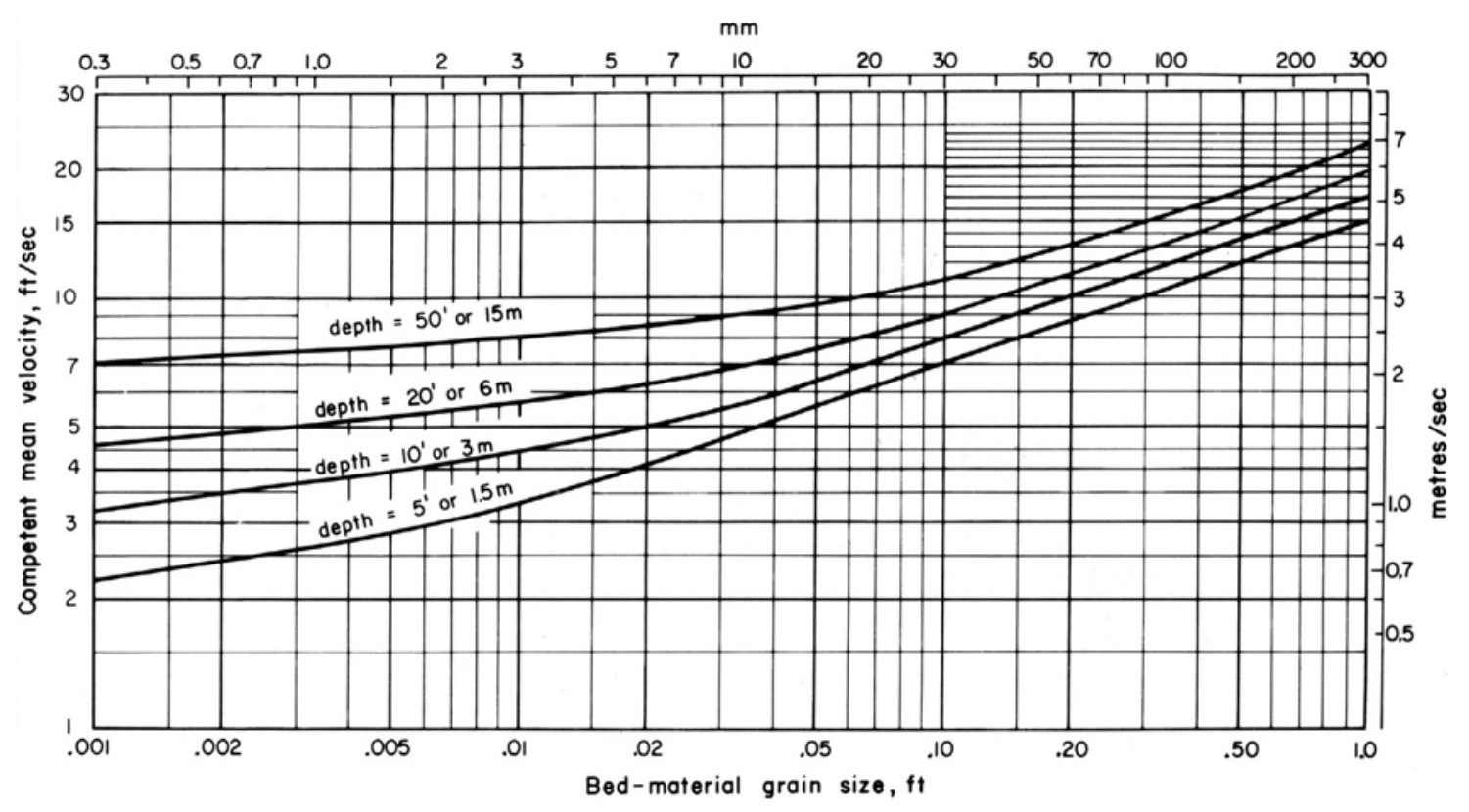

Figure D-7. Competent velocities for non-cohesive sediment as presented in Neill (1973).

Neill (1973) also provided a table (table D-6) for estimating competent velocities for cohesive soils. To determine these values, Neill (1973) converts critical shear stress data for cohesive soils, as determined by investigations in Russia and the United States, to competent velocities. Neill (1973) selected values of $0.035,0.12$, and 0.35 pounds per square foot $\left(\mathrm{lb} / \mathrm{ft}^{2}\right)$ to represent critical shear stresses for easily erodible, average, and resistant cohesive soils, respectively. Using the following equation, he converted the shear stresses into competent velocities for selected flow depths

$$
V_{c o h}=7.5 y_{1}^{1 / 6} \tau_{c}{ }^{1 / 2}
$$

where

$V_{c o h}$ is the competent velocity for cohesive soils,

$\tau_{\mathrm{c}}$ is the critical shear stress for cohesive soils, and

$\mathrm{y}_{l}$ is defined in equation 1 . 
Neill (1973) cautions that these values should be "used as a rough guide only."

Table D-6. Competent velocities for cohesive soils as suggested by Neill (1973).

\begin{tabular}{|c|c|c|c|}
\hline \multirow[b]{2}{*}{$\begin{array}{l}\text { Depth of flow } \\
\text { (feet) }\end{array}$} & \multicolumn{3}{|c|}{ Competent mean velocity } \\
\hline & $\begin{array}{l}\text { Low values-easily } \\
\text { erodible material } \\
\text { (feet per second) }\end{array}$ & $\begin{array}{l}\text { Average values } \\
\text { (feet per second) }\end{array}$ & $\begin{array}{c}\text { High values_resistant } \\
\text { material } \\
\text { (feet per second) }\end{array}$ \\
\hline 5 & 1.9 & 3.4 & 5.9 \\
\hline 10 & 2.1 & 3.9 & 6.6 \\
\hline 20 & 2.3 & 4.3 & 7.4 \\
\hline 50 & 2.7 & 5.0 & 8.6 \\
\hline
\end{tabular}

In order to incorporate Neill's (1973) competent velocity into mathematical algorithms, Chang and Davis (1999) extended Neill's curves (fig. D-7) below sediment sizes of $0.3 \mathrm{~mm}$ and transformed the curves into the following equations:

$$
\begin{array}{ll}
\mathrm{D}_{50} \geq 0.1, & V_{\text {comp }}=11.5 y_{1}{ }^{0.167} D_{50}{ }^{0.33} \\
0.1>\mathrm{D}_{50}>0.001, & V_{\text {comp }}=10.14\left(\frac{y_{1}}{3.281}\right)^{x} D_{50}{ }^{0.25} \\
\mathrm{D}_{50} \leq 0.001 & V_{\text {comp }}=0.997 y_{1}^{0.5}
\end{array}
$$

where $V_{\text {comp }}$ is Neill's competent velocity, in feet per second;

$$
\begin{aligned}
& x=0.155 / D_{50}^{0.18} ; \text { and } \\
& D_{50} \text { and } \mathrm{y}_{1} \text { are defined in equation } 1 .
\end{aligned}
$$

\section{Keown and Others (1977)}

In an extensive literature review of streambank protection methods, Keown and others (1977) presented a table (table D-7) of non-scour velocities from the work of Mamak (1964). Keown and others (1977) only give a brief description of this table, indicating that the non-scour velocities were based on observations of canal performances. Based on this description, it seems reasonable to assume that the non-scour velocities are similar to the maximum permissible velocities of Etcheverry (1915) and Fortier and Scobey (1926). The data in table D-7 are from Richardson and others (2001). The original table in Keown and others (1977) provides ranges of non-scour velocities for a given soil class and flow depth, whereas Richardson and others (2001) have provided the mean value. In some investigations, it may be of benefit to have the original range of the non-scour velocities. Keown and others (1977) also provide a brief summary of the work by Gibbs (1962) on permissible tractive forces for cohesive and non-cohesive soils. Using a procedure similar to that of equation 16, it is possible to convert the tractive forces to approximate maximum permissible velocities and may be an avenue of investigation for the future. 
Table D-7. Non-scour velocities from Mamak (1964) as presented in Keown and others (1977) and modified by Richardson and others (2001).

\begin{tabular}{|c|c|c|c|c|c|}
\hline \multirow{3}{*}{ Kind of soil } & \multirow{3}{*}{$\begin{array}{l}\text { Grain size } \\
\text { (millimeter) }\end{array}$} & \multicolumn{4}{|c|}{$\begin{array}{l}\text { Approximate non-scour velocities } \\
\text { (feet per second) }\end{array}$} \\
\hline & & \multicolumn{4}{|c|}{ Mean depth } \\
\hline & & 1.3 feet & 3.3 feet & 6.6 feet & 9.8 feet \\
\hline \multicolumn{6}{|c|}{ For non-cohesive soils } \\
\hline Boulder & $>256$ & 15.1 & 16.7 & 19.0 & 20.3 \\
\hline Large cobbles & $256-128$ & 11.8 & 13.4 & 15.4 & 16.4 \\
\hline Small cobbles & $128-64$ & 7.5 & 8.9 & 10.2 & 11.2 \\
\hline Very coarse gravel & $64-32$ & 5.2 & 6.2 & 7.2 & 8.2 \\
\hline Coarse gravel & $32-16$ & 4.1 & 4.7 & 5.4 & 6.1 \\
\hline Medium gravel & $16-8.0$ & 3.3 & 3.7 & 4.1 & 4.6 \\
\hline Fine gravel & $8.0-4.0$ & 2.6 & 3.0 & 3.3 & 3.8 \\
\hline Very fine gravel & $4.0-2.0$ & 2.2 & 2.5 & 2.8 & 3.1 \\
\hline Very coarse sand & $2.0-1.0$ & 1.8 & 2.1 & 2.4 & 2.7 \\
\hline Coarse sand & $1.0-0.5$ & 1.5 & 1.8 & 2.1 & 2.3 \\
\hline Medium sand & $0.5-0.25$ & 1.2 & 1.5 & 1.8 & 2.0 \\
\hline Fine sand & $0.25-0.125$ & 0.98 & 1.3 & 1.6 & 1.8 \\
\hline \multicolumn{6}{|c|}{ For compact cohesive soils } \\
\hline Sandy loam (heavy) & & 3.3 & 3.9 & 4.6 & 4.9 \\
\hline Sandy loam (light) & & 3.1 & 3.9 & 4.6 & 4.9 \\
\hline $\begin{array}{l}\text { Loess soils in the con- } \\
\text { ditions of finished } \\
\text { settlement }\end{array}$ & & 2.6 & 3.3 & 3.9 & 4.3 \\
\hline
\end{tabular}

\section{Application of Selected Threshold Velocities to South Carolina Data}

Selected methods for estimating threshold velocities, as identified in the limited literature review, were applied to 144 bridge sites in South Carolina, where 209 observations of abutment scour previously were made (Benedict, 2003). The data included 65 sites in the Piedmont region where clayey soils are predominant and 79 sites in the Coastal Plain region where sandy soils are predominant. The estimates of threshold velocities were plotted against the median grain size, and the data were grouped by critical velocity methods and maximum permissible velocity methods. When comparing the trends of the selected methods for estimating threshold velocities, it is helpful to keep in mind that, with regard to using threshold velocities for predicting scour, predicted scour will be inversely proportional to the selected threshold velocity. Therefore, as threshold velocities increase, predicted scour depths decrease.

\section{Trends for Selected Critical Velocity Methods}

The relation of critical velocity and median grain size (fig. D-8) was compared to the trends for the HEC-18 equation (Richardson and Davis, 2001; eq. 2), equation 6 that utilizes the Strickler (1923) and Shields (1935) relations, equation 7 that utilizes the Blodgett (1986) and Shields (1935) relations, and the Vanoni (1975) average curve (eq. 12). The trends in figure D-8 indicate that there is a wide discrepancy among the selected critical velocity methods. The Vanoni (1975) curve indicates that for grain sizes between 0.1 to $0.4 \mathrm{~mm}$, the critical velocity is relatively constant. As grain size increases, one would expect that the critical velocity required to remove the larger grain sizes also would increase. For grain sizes greater than $0.4 \mathrm{~mm}$, the Vanoni (1975) curve displays this trend, which appears reasonable. As grain size decreases below $0.1 \mathrm{~mm}$, one might expect that the critical velocity required to remove the smaller grain sizes would decrease as well. However, the cohesive properties of the 


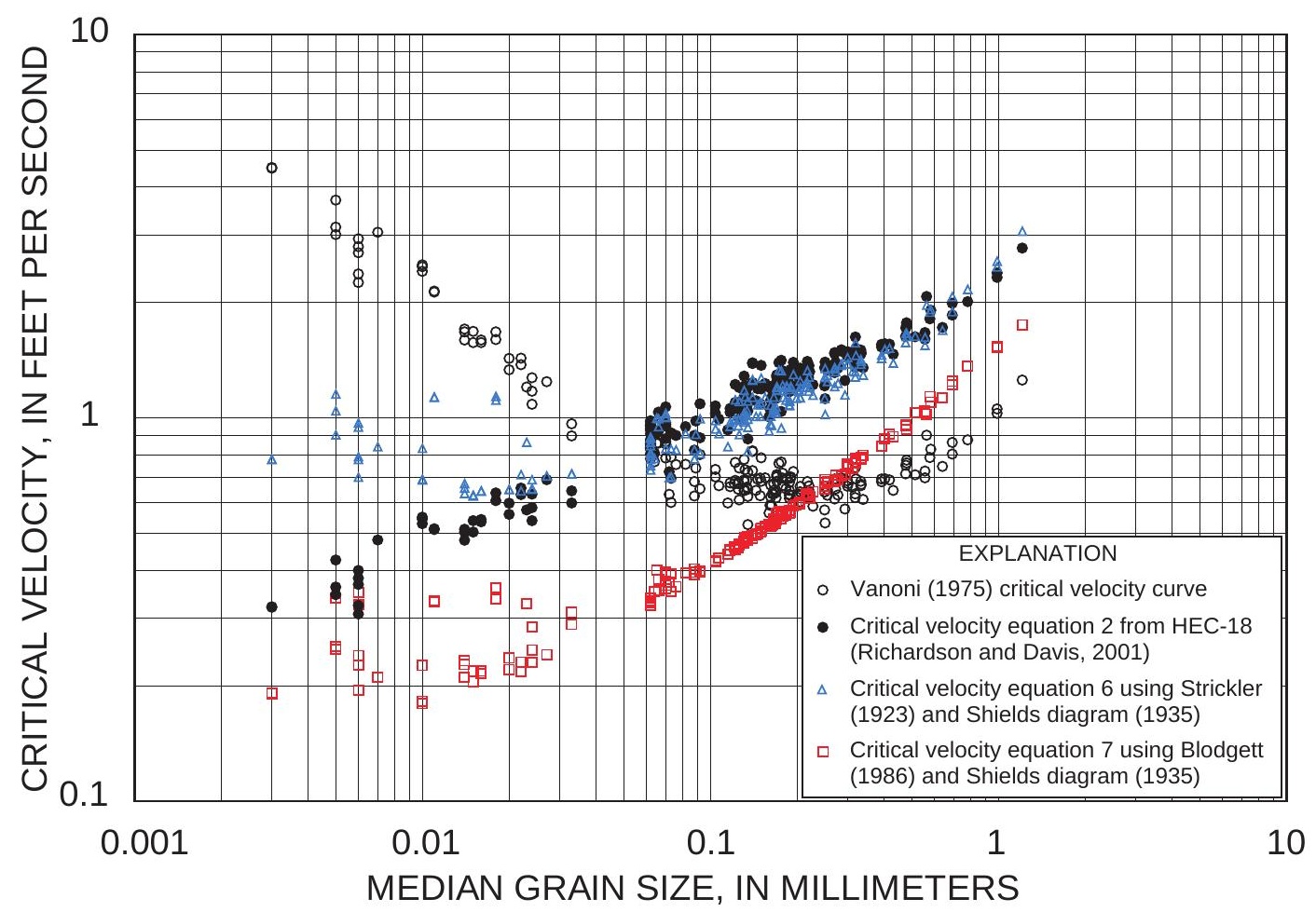

Figure D-8. Relation of median grain size and critical velocity for selected critical velocity equations using field data collected in South Carolina (Benedict, 2003).

smaller grained soils (less than about $0.1 \mathrm{~mm}$ ) found in the field, require that threshold velocities increase in order to achieve erosion. Again, the Vanoni (1975) curve displays this trend, which appears reasonable.

In contrast, the HEC-18 equation (Richardson and Davis, 2001; eq. 2) indicates that critical velocity is proportional to grain size for the entire range of the South Carolina data, including cohesive soils. (It should be kept in mind that the HEC-18 equation was derived for loose-grained soils and is not intended for application to cohesive soils. However, because of limited guidance on analyzing scour in cohesive materials, the equation is often applied to such soils. The following analysis provides insights on the error that can occur when the HEC-18 equation is applied to cohesive soils.) With regard to the computation of scour, the HEC-18 equation (Richardson and Davis, 2001; eq. 2) will tend to produce large (and even excessive) estimates of scour in cohesive soils. This trend clearly can be seen in figure D-1A where the HEC-18 critical velocity gives excessive abutment scour estimates in the cohesive soils of the Piedmont. Benedict and Caldwell (2006) also showed this excessive trend in the computation of clear-water contraction scour (fig. D-2) when the HEC-18 (Richardson and Davis, 2001) equation is applied to cohesive soils. With respect to non-cohesive sediments (approximately $0.06 \mathrm{~mm}$ and greater), the HEC-18 equation gives critical velocities that are larger than the other methods (fig. D-8), indicating that it will tend to give smaller estimates of scour for non-cohesive sediment. Figure D-1A, where the HEC-18 equation (Richardson and Davis, 2001; eq. 2) was used to estimated abutment scour, shows frequent underprediction in the sandy soils of the Coastal Plain of South Carolina, indicating that the HEC-18 critical velocity equation may provide estimates of critical velocity that are too large for non-cohesive sediments. Benedict and Caldwell (2006) also showed the trend of frequent underprediction in the computation of clear-water contraction scour (fig. D-2) when the HEC-18 (Richardson and Davis, 2001) equation is applied to non-cohesive soils. This further indicates that the HEC-18 equation may provide excessive estimates of critical velocity for non-cohesive soils ( $0.06 \mathrm{~mm}$ and greater). When comparing the HEC-18 critical velocity (Richardson and Davis, 2001) to the Vanoni (1975) curve, it is interesting to note that the Vanoni (1975) curve gives larger values for cohesive soils and lower values for non-cohesive soils, which would tend to reduce the overpredicton and underprediction associated with using the HEC-18 critical velocity for scour prediction. Therefore, the Vanoni (1975) curve for critical velocity may be a better estimate of threshold velocities used in predicting scour. Further investigation is required to confirm this. 
Equation 6, which uses the Strickler (1923) and Shields (1935) relations, and equation 7, which uses the Blodgett (1986) and Shields (1935) relations, have similar trends to one another (fig. D-8) with an average offset of 0.6 foot per second (ft/s) between the methods as applied to the South Carolina data. Equation 7 consistently gives lower estimates of critical velocity and, therefore, will give higher values of predicted scour. When compared to the HEC-18 equation (Richardson and Davis, 2001; eq. 2), equation 7 gives lower values of critical velocity, which indicates that it will likely give excessive estimates of scour in cohesive soils but perhaps reduce underprediction for non-cohesive soils. In contrast, equation 6 gives similar values to the HEC-18 equation (eq. 2) for grain sizes greater than approximately $0.06 \mathrm{~mm}$ but larger estimates of critical velocity for the smaller cohesive soils. This indicates that equation 6 will tend to give smaller estimates of scour in cohesive soils than the HEC-18 equation (Richardson and Davis, 2001; eq. 2) but produce similar estimates of scour for non-cohesive soils.

\section{Trends for Selected Maximum Permissible Velocity Methods}

The application of Fortier and Scobey (1926), the Russian Bureau of Methodology (1936) for cohesive soils, and Neill's (1973) competent velocity for cohesive soils required that a soil category be identified for each site in order to select a threshold velocity. (These three methods for estimating maximum permissible velocities will be called tabular methods for the remainder of this paper.) To assist in the selection of a soil category for each tabular method, the South Carolina data were placed in the following three groups: (1) sandy loams that have a high content of sand, are more easily eroded, and are less compacted; (2) clayey loams that have a high content of clay, are resistant to erosion, and are compacted; and (3) stiff clays that have a high content of clay, are very resistant to erosion, and are very compacted. The selection of these groups was based on limited soils data, including the median grain size and a description of the soils during site visits. Therefore, the groups should not be viewed as categories based on soil tests but rather subjective groups developed with limited data to help display the trends of the maximum permissible velocity methods. Most of the Coastal Plain sites, where soils are primarily sandy and suspended sediments are negligible, were placed in group 1. A few Coastal Plain sites have clayey soils, and they were placed in group 2. Most of the Piedmont sites, where soils primarily are clayey and suspended clayey sediments are high, were placed in group 2 , with a few sites falling into groups 1 and 3 . These three soil groups were used to assist in selecting maximum permissible velocities for each method. Table D-8 lists the three soils groups for the South Carolina data with the selected soils descriptions for the given maximum permissible velocity methods and the associated velocities.

The trends of the three tabular methods described in the preceding paragraph are displayed in figure D-9A. A band of data that falls between approximately 2 and $6 \mathrm{ft} / \mathrm{s}$ represents the range of the results for Fortier and Scobey (1926), the Russian Bureau of Methodology (1936) for cohesive soils, and Neill's (1973) competent velocity for cohesive soils. The three general categories of soils for the South Carolina data are fairly distinct for each of the tabular methods, providing values in close proximity to each other for the respective soil groups. When compared with the HEC-18 critical velocity equation (Richardson and Davis, 2001) (fig. D-9A), the tabular methods, which include cohesive soils, provide significantly larger values of threshold velocities for cohesive soils (approximately $0.06 \mathrm{~mm}$ or less), indicating that they may reduce the excessive overprediction of scour that is associated with the HEC-18 equation when applied to cohesive soils (figs. D-1 and D-2). In the case of noncohesive sediments, the tabular methods also tend to provide larger values of threshold velocities, indicating that they may increase the underprediction of scour that is associated with the HEC-18 equation when applied to non-cohesive soils (figs. D-1 and D-2).

A notable weakness of the tabular methods is that the maximum permissible velocity is not a function of grain size but primarily of soil category. A possible alternative to using the general soil category with the tabular methods is to develop curves that display the approximate relation of the maximum permissible velocity and median grain size by using the tabular data from each method. Figure D-3 provides an example of converting maximum permissible velocity tabular data into approximate curves (in this case Fortier and Scobey (1926)). It is possible to do this for the other tabular methods and then transform the curves into a series of equations for computing maximum permissible velocities for all three methods. This is perhaps a procedure that could be applied in future research. 
Table D-8. Maximum permissible velocities selected for the general soils groups for the South Carolina data.

\begin{tabular}{|c|c|c|c|c|c|c|}
\hline \multirow[b]{3}{*}{$\begin{array}{l}\text { General soils group for } \\
\text { South Carolina data }\end{array}$} & \multicolumn{6}{|c|}{ Method for estimating maximum permissible velocity } \\
\hline & \multicolumn{2}{|c|}{ Fortier and Scobey (1926) } & \multicolumn{2}{|c|}{$\begin{array}{l}\text { Russian Bureau of } \\
\text { Methodology (1936) } \\
\text { for cohesive soils }\end{array}$} & \multicolumn{2}{|c|}{$\begin{array}{l}\text { Neill's (1973) competent } \\
\text { velocity for cohesive soils }\end{array}$} \\
\hline & $\begin{array}{c}\text { Soil } \\
\text { description }\end{array}$ & $\begin{array}{l}\text { Unadjusted } \\
\text { maximum } \\
\text { permissible } \\
\text { velocity } \\
\text { (feet per } \\
\text { second) }\end{array}$ & $\begin{array}{c}\text { Soil } \\
\text { description }\end{array}$ & $\begin{array}{l}\text { Unadjusted } \\
\text { maximum } \\
\text { permissible } \\
\text { velocity } \\
\text { (feet per } \\
\text { second) }\end{array}$ & $\begin{array}{c}\text { Soil } \\
\text { description }\end{array}$ & $\begin{array}{c}\text { Unadjusted } \\
\text { maximum } \\
\text { permissible } \\
\text { velocity } \\
\text { (feet per } \\
\text { second) }\end{array}$ \\
\hline $\begin{array}{l}\text { Group 1 } \\
\text { Sandy loams that have a high content } \\
\text { of sand, are more easily eroded, } \\
\text { and are less compacted }\end{array}$ & $\begin{array}{l}\text { Ordinary firm } \\
\text { loam, clear } \\
\text { water, no } \\
\text { detritus }\end{array}$ & 2.5 & $\begin{array}{l}\text { Lean clayey } \\
\text { soils, fairly } \\
\text { compacted }\end{array}$ & 2.3 & $\begin{array}{l}\text { Easily } \\
\text { erodible } \\
\text { material }\end{array}$ & 1.9 \\
\hline $\begin{array}{l}\text { Group 2 } \\
\text { Clayey loams that have a high } \\
\text { content of clay, are resistant to } \\
\text { erosion, and are compacted }\end{array}$ & $\begin{array}{l}\text { Ordinary firm } \\
\text { loam, water } \\
\text { transport- } \\
\text { ing colloi- } \\
\text { dal silts }\end{array}$ & 3.5 & $\begin{array}{l}\text { Clays, com- } \\
\text { pacted }\end{array}$ & 3.9 & Average & 3.4 \\
\hline $\begin{array}{l}\text { Stiff clays that have a high content of } \\
\text { clay, are very resistant to erosion, } \\
\text { and are very compacted }\end{array}$ & $\begin{array}{l}\text { Stiff clay } \\
\quad \text { (very } \\
\text { colloidal), } \\
\text { water } \\
\text { transport- } \\
\text { ing colloi- } \\
\text { dal silts }\end{array}$ & 5.0 & $\begin{array}{l}\text { Heavy clayey } \\
\text { soils, very } \\
\text { compacted }\end{array}$ & 5.6 & $\begin{array}{l}\text { Resistant } \\
\text { material }\end{array}$ & 5.9 \\
\hline
\end{tabular}

Figure D-9B shows Neill's (1973) curves for competent velocity for non-cohesive soils (as transformed into equations by Chang and Davis (1999) (eq. 17)) in relation to the HEC-18 equation for critical velocity (Richardson and Davis, 2001; eq. 2) and the Vanoni (1975) average curve (eq. 12). The trends indicate that Neill's competent velocities tend to be larger than the HEC-18 equation and the Vanoni critical velocities. Thus, Neill's (1973) competent velocities for non-cohesive soils may reduce the excessive overprediction of scour that is associated with the HEC-18 equation when applied to cohesive soils (figs. D-1 and D-2). In the case of non-cohesive sediments, Neill's (1973) competent velocities for non-chohesive soils may increase the underprediction of scour that is associated with the HEC-18 equation when applied to non-cohesive soils (figs. D-1 and D-2). 
A.
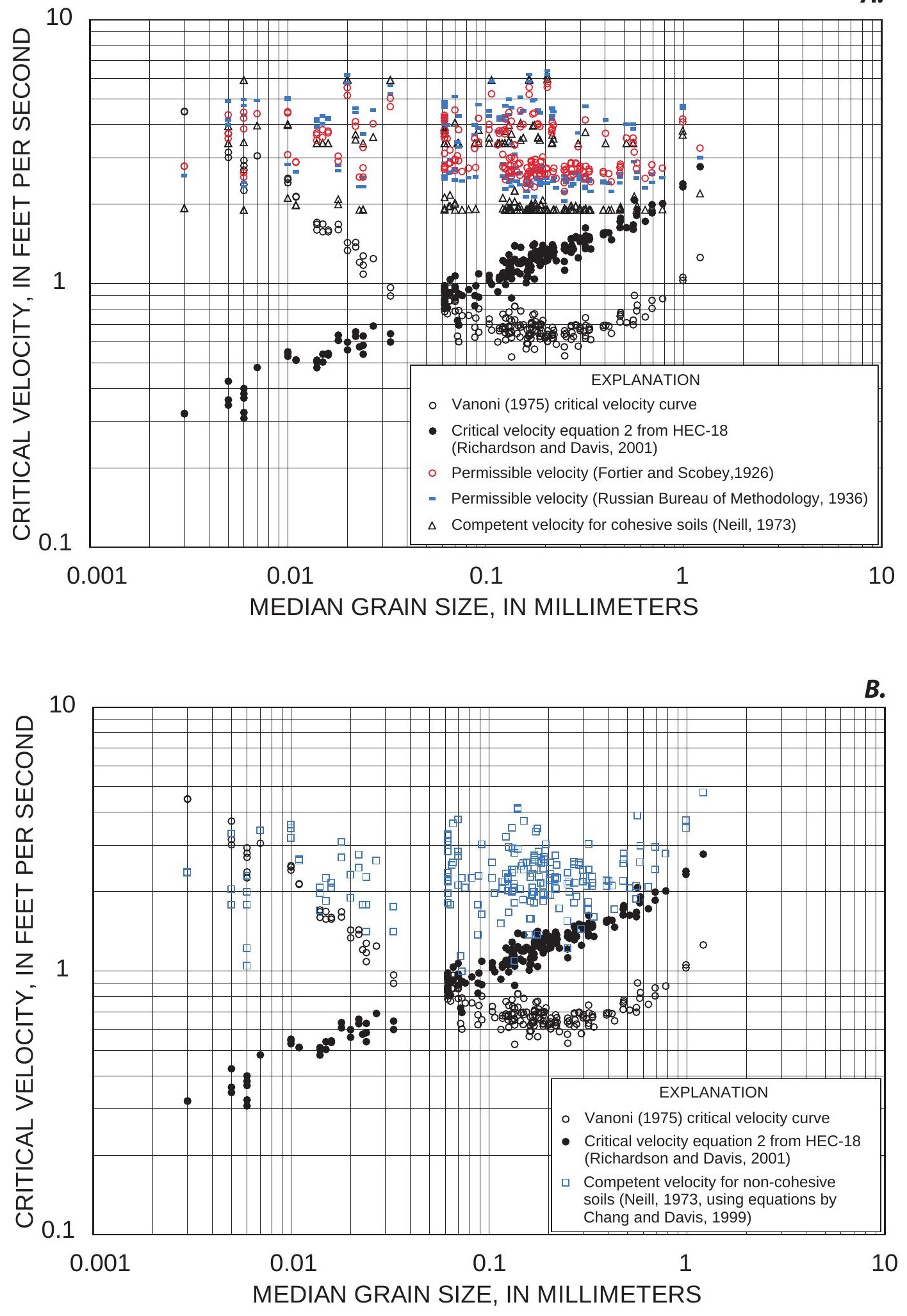

Figure D-9. Relation of median grain size and critical velocity for selected critical velocity equations and (A) selected maximum permissible velocity methods and (B) Neill's (1973) competent velocity for non-cohesive sediments using field data collected in South Carolina. 


\section{Summary}

A limited literature review of threshold velocities for soil erosion was conducted, and eight methods for estimating these velocities were selected and reviewed. Four of these methods estimated critical velocity, which is a threshold velocity at initiation of motion for loose-grain sediments. The other methods estimated maximum permissible velocity, which is the maximum velocity that a natural sediment can sustain without appreciable erosion. These two categories of threshold velocities, although related, are really distinct phenomenon and can provide differing values for threshold conditions.

A summary of each method for estimating threshold velocities was provided in this paper and a comparison of those methods, as applied to data from South Carolina, was made. The comparison showed that there can be significant differences in threshold velocities between the various methods, indicating a need for additional research to identify the most reasonable method for determining threshold velocities.

\section{Selected References}

Benedict, S.T., 2003, Clear-water abutment and contraction scour in the Coastal Plain and Piedmont Provinces of South Carolina, 1996-99: U.S. Geological Survey, Water-Resources Investigations Report 03-4064, 137 p.

Benedict, S.T., and Caldwell, A.W., 2006, Development and evaluation of clear-water pier and contraction scour envelope curves in the Coastal Plain and Piedmont of South Carolina: U.S. Geological Survey Scientific Investigations Report 2005-5289, $98 \mathrm{p}$.

Benedict, S.T., Deshpande, Nikhil, Aziz, N.M., and Conrads, P.A., 2006, Trends of abutment-scour prediction equations applied to 144 field sites in South Carolina: U.S. Geological Survey Open-File Report 2003-295, 150 p.

Blodgett, J.C., 1986, Rock riprap design for protection of stream channels near highway structures: U.S. Geological Survey Water-Resources Investigations Report 86-4127, 60 p.

Bureau of the Methodology of the Hydro-Energo Plan, 1936, Standards for permissible non-eroding velocities: Moscow, USSR, May 1936 (cited in Lane, 1955).

Chang, F.M., and Davis S.R., 1999, Maryland SHA procedure for estimating scour at bridge abutments, Part 2—Clear water scour, in Richardson, E.V., and Lagasse, P.F., eds., American Society of Civil Engineers Compendium, Stream Stability and Scour at Highway Bridges, Reston, VA, p. 412-416.

Chow, V.T., 1959, Open channel hydraulics: New York, McGraw-Hill Book Co., 680 p.

DuBuat, P.L.G., 1786, Principes d'hydraulique (2d ed.): Paris, De L'Imprimerie de Monsieur, (cited in Graf, 1971).

Etcheverry, B.A., 1915, Irrigation practice and engineering, v. 2, Conveyance of Water: McGraw-Hill Book Co., 364 p.

Fischenich, Craig, 2001, Stability thresholds for stream restoration materials: Vicksburg, MS, U.S. Army Corps of Engineers, Engineer Research and Development Center, ERDC-TN-EMRRP-SR-29.

Fortier, Samuel, and Scobey, F.C., 1926, Permissible canal velocities: Transactions of the American Society of Civil Engineers, v. 89 , paper no. 1588 , p. $940-984$.

Gibbs, H.J., 1962, A study of erosion and tractive force characteristics in relation to soil mechanics properties: Denver, CO, U.S. Department of the Interior, Bureau of Reclamation, Soils Engineering Report No. EM-643, (cited in Keown and others, 1977).

Graf, W.H., 1971, Hydraulics of sediment transport: New York, McGraw-Hill Book Co., 513 p.

Hjulstrom, F., 1935, Studies of the morphological activities of rivers as illustrated by the River Fyris: Bulletin, Geological Institute of Uppsala, Sweden, v. 25, p. 221-527 (cited in Vanoni, 1975).

Julien, P.Y., 1995, Erosion and sedimentation: New York, Cambridge University Press, 280 p. 
Keown, M.P., Oswalt N.P., Perry, E.B., and Dordeau E.A., Jr., 1977, Literature survey and preliminary evaluation of streambank protection methods: U.S. Army Corps of Engineers, Waterways Experiment Station, Technical Report H-79-9.

Lane, E.W., 1955, Design of stable channels: Transactions of the American Society of Civil Engineers, v. 120, paper no. 2776, p. 1234-1260.

Laursen, E.M., 1963, An analysis of relief bridge scour: Journal Hydraulic Division, American Society of Civil Engineering, v. 92, no. HY3.

Mahmood, K., and Shen, H.W., 1971, Regime concept of sediment-transporting canals and rivers, in Shen, H.W., ed., River mechanics, v. 2, Fort Collins, CO, p. 30-1-30-39.

Mamak, W., 1964, River regulation: Arkady, Warszaw, Poland (translated by Israel Program for Scientific Translations) (cited in Keown and others, 1977).

Maryland State Highway Administration, 2005, Evaluating scour at bridges-Manual for hydrologic and hydraulic design: Maryland State Highway Administration, v. 2, chap. 11.

Maryland State Highway Administration, 2006, Maryland State Highway Administration abutment scour program (ABSCOUR): Maryland State Highway Administration, version 7, build 1.03, compiled January 6, 2006.

Neill, C.R., ed., 1973, Guide to bridge hydraulics: Toronto, Ontario, Roads and Transportation Association of Canada, University of Toronto Press, 191 p.

Raudkivi, A.J., 1976, Loose boundary hydraulics ( $2^{\mathrm{d}}$ ed.): Oxford, Pergamon Press, 397 p.

Richardson, E.V., and Davis, S.R., 2001, Evaluating scour at bridges: Federal Highway Administration Hydraulic Engineering Circular No. 18, Publication FHWA-NHI-01-001, 378 p.

Richardson, E.V., Simons, D.B., and Lagasse, P.F., 2001, River engineering for highway encroachments—Highways in the river environment: Federal Highway Administration, Publication No. FHWA-NHI-01-004, 646 p.

Shields, I.A., 1935, Anwendung der Aenlichkeitsmechanik und der Turbulenzforschung auf die Geschiebebewegung, Berlin, Germany, translated to English by W.P. Ott and J.C. van Uchelen, California Institute of Technology, Pasadena, CA (cited in Richardson and others, 2001).

Strickler, A., 1923, Beiträge zur Frage der Geschwindigkeits formel und der Rauhigkeitszahlen für Ströme, Kanale und geschlossene Leitungen (Some contributions to the problems of a velocity formula and roughness coefficients for rivers, canals, and closed conduits), Mitteilungen des Eidgenössischen Amtes für Wasserwirtschaft No. 16, Bern, Switzerland (cited in Chow, 1959).

Vanoni, V.A., 1975, Sedimentation engineering, American Society of Civil Engineers Task Committee for the Preparation of the Manual on Sedimentation of the Sedimentation Committee of the Hydraulics Division (cited in Yang, 1996).

Yang, C.T., 1996, Sediment transport theory and practice: New York, McGraw-Hill, 396 p. 


\section{Appendix E}

Determination of soil erosion rates at five sites in South Carolina. 


\title{
Determination of Soil Erosion Rates at Five Sites in South Carolina
}

\author{
By Stephen T. Benedict ${ }^{1}$
}

The U.S. Geological Survey (USGS), in cooperation with the South Carolina Department of Transportation (SCDOT), made 209 field measurements of abutment scour in South Carolina (Benedict, 2003). These data have been compiled into a database and offer a valuable resource to researchers investigating the phenomenon of abutment scour. To enhance the usefulness of this database, the USGS, in cooperation with the Federal Highway Administration (FHWA), has compiled the data into various spreadsheets and added supplemental data pertinent to the measured abutment scour. Part of the enhancement of the database included the determination of soil erosion rates at five sites in the cohesive soils of the Piedmont, using the Erosion Function Apparatus (EFA). The EFA was developed at Texas A\&M University to measure the erosion rates of different types of soil, ranging from clay to gravel and from soft soils to soft rocks. Erosion rates determined by the EFA can be used in the Scour-Rate-InCohesive-Soils (SRICOS) method to predict scour depths. (An overview of the EFA and SRICOS is available at URL

http://tti.tamu.edu/geotech/scour/, accessed June 28, 2006.)

The EFA and SRICOS methods originally were developed to evaluate scour in cohesive soils. Abutment-scour data collected in the clayey soils of the South Carolina Piedmont region provide a good opportunity to verify this method. Therefore, five Piedmont sites, where abutment-scour depths were measured previously (Benedict, 2003), were selected for the determination of soil erosion rates using the EFA (table E-1 and fig. E-1). The sites have a wide range in scour depths (0 to 13.7 feet), indicating that the soils have varying degrees of resistance to scour. Additionally, four of the sites experienced a flood in August 1995 where flows were close to or exceeded the 100-year flow magnitude. (Refer to Benedict (2003) for details about this flood.) Estimates of peak flows resulting from this flood, along with hydraulics estimated with a surface-water model, are available at these sites and provide insight into the flow conditions that may have created the measured scour.

${ }^{1}$ Hydrologist, U.S. Geological Survey, Suite 200, 405 College Avenue, Clemson, SC 29631.

Table E-1. Sites selected for the determination of soil erosion rates using the Erosion Function Apparatus.

[SCDOT, South Carolina Department of Transportation; S, secondary road; DOT, Department of Transportation; —, no data; S.C., South Carolina route]

\begin{tabular}{|c|c|c|c|c|c|c|}
\hline County & Road & Stream & $\begin{array}{l}\text { SCDOT } \\
\text { structure } \\
\text { number }\end{array}$ & $\begin{array}{l}\text { Measured } \\
\text { scour at left } \\
\text { abutment } \\
\text { (feet) }\end{array}$ & $\begin{array}{l}\text { Measured } \\
\text { scour at right } \\
\text { abutment } \\
\text { (feet) }\end{array}$ & $\begin{array}{c}\text { Agency } \\
\text { conducting } \\
\text { soil erosion test }\end{array}$ \\
\hline Cherokee & S-348 & Buffalo Creek & 117034800100 & 0 & 2 & Illinois DOT \\
\hline${ }^{\mathrm{a}}$ Laurens & S-36 & Reedy River & 307003600200 & 5.2 & - & Texas A\&M University \\
\hline${ }^{\mathrm{a}}$ Laurens & $\mathrm{S}-112$ & Enoree River & 307011200100 & - & 1.7 & North Carolina DOT \\
\hline${ }^{\mathrm{a}}$ Newberry & $\mathrm{S}-81$ & Enoree River & 367008100200 & - & 13.7 & Minnesota DOT \\
\hline${ }^{\mathrm{a}}$ Spartanburg & S.C. 146 & Enoree River & 424014600100 & 0 & 3.1 & North Carolina DOT \\
\hline
\end{tabular}

${ }^{\mathrm{a}}$ This site experienced the August 1995 flood. 


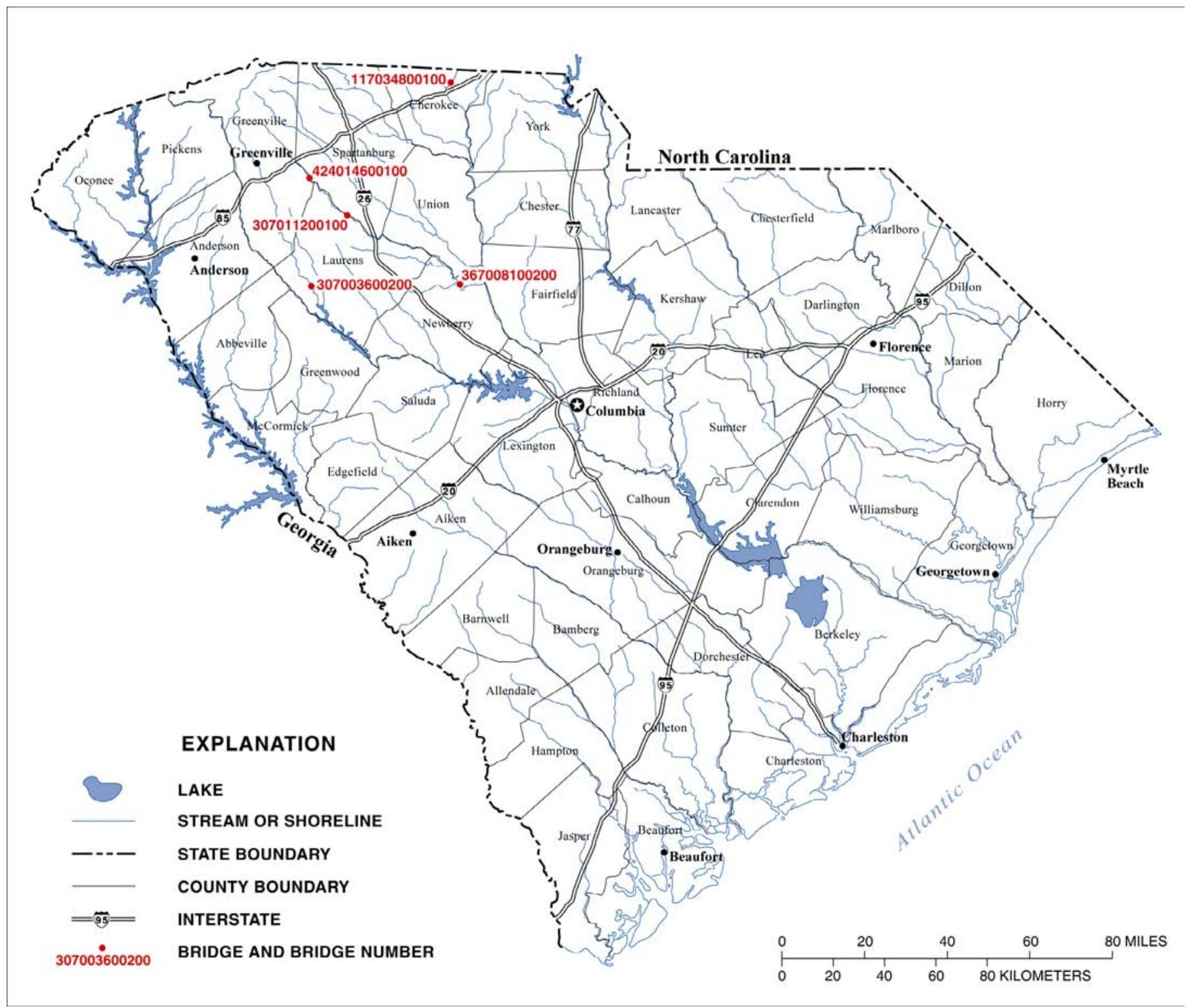

Figure E-1. General location map for sampling sites in South Carolina.

A Geoprobe direct push sampler mounted on a truck (fig. E-2) was used to obtain Shelby tube soil samples at each site. The Shelby tubes were made from galvanized steel, having a 3-inch outside diameter and a length of 30 inches. Sampling methods were based on the American Society for Testing and Materials (ASTM) Standard D-1587, "Standard Practice for Thin-Walled Tube Sampling of Soils for Geotechnical Purposes." Samples were shipped to pre-selected laboratories in wooden boxes that were constructed according to ASTM Standard D-4220 ("Standard Practices for Preserving and Transporting Soil Standards") to minimize disturbance during shipping. The laboratories consisted of a University and three State Transportation Departments (table E-1) that agreed to conduct the EFA tests free of charge. (The author would like to acknowledge and thank the following individuals and agencies for assistance in conducting the EFA tests: Dr. Jean-Louis Briaud of Texas A\&M University; Mr. David R. Henderson and Mr. Travis W. Allen of the North Carolina Department of Transportation; Dr. Riyad M. Wahab of the Illinois Department of Transportation; and Mr. Gary Person and Mr. Derrick Dasenbrock of the Minnesota Department of Transportation.) 


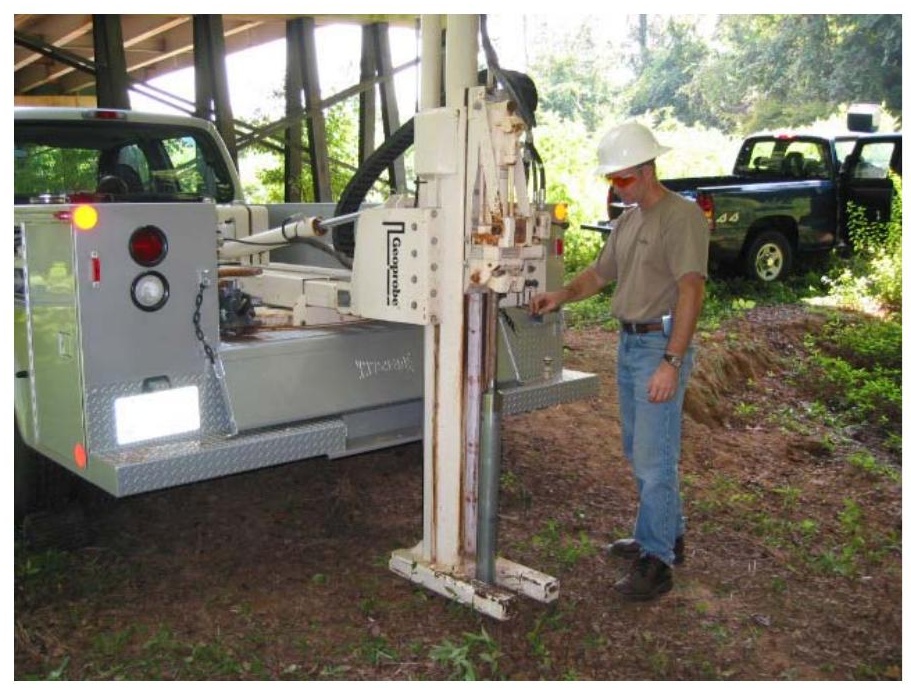

Figure E-2. Geoprobe direct push sampler used to collect Shelby tube soils samples (photograph from files of the U.S. Geological Survey, South Carolina Water Science Center, August 2, 2004).

To provide some understanding of the basin and field conditions at each site, tables E-2 and E-3 list selected basin characteristics for each bridge as well as selected variables associated with the measured abutment scour depths. In addition, a brief summary for each site follows, including a topographic map, photographs, sketches identifying the approximate location of sample collection, and a table describing each sample. Additional information (photographs, estimated hydraulics, observed scour, and predicted scour) for each site is available in Benedict (2003), Benedict and others (2006), and Benedict and Caldwell (2006). Data for the EFA tests have been compiled in spreadsheets and are available at http://pubs.water.usgs.gov/ofro3-295/ data.html\#EFA .

Table E-2. Selected characteristics for sites selected for the determination of soil erosion rates.

[S, Secondary road; S.C., South Carolina route]

\begin{tabular}{lcccccc} 
County & Road & Stream & $\begin{array}{c}\text { Slope of } \\
\text { streambed } \\
\text { (feet per foot) }\end{array}$ & $\begin{array}{c}\text { Drainage } \\
\text { area } \\
\text { (square } \\
\text { miles) }\end{array}$ & $\begin{array}{c}\text { Bridge } \\
\text { length } \\
\text { (feet) }\end{array}$ & $\begin{array}{c}\text { aGeometric } \\
\text { contraction } \\
\text { ratio }\end{array}$ \\
\hline Cherokee & S-348 & Buffalo Creek & 0.00055 & 175 & 320 & 0.51 \\
Laurens & S-36 & Reedy River & 0.00142 & 236 & 250 & 0.58 \\
Laurens & S-112 & Enoree River & 0.00074 & 256 & 300 & 0.34 \\
Newberry & S-81 & Enoree River & 0.00050 & 677 & 330 & 0.67 \\
Spartanburg & S.C. 146 & Enoree River & 0.00148 & 127 & 292 & 0.51 \\
\hline
\end{tabular}

${ }^{\mathrm{a}}$ Determined from the Water-Surface Profile (WSPRO) model (Shearman, 1990) with the 100-year flow. 
Table E-3. Selected abutment data for sites selected for the determination of soil erosion rates.

[S, secondary road; S.C. South Carolina route]

\begin{tabular}{|c|c|c|c|c|c|c|c|}
\hline County & Road & Stream & $\begin{array}{c}\text { Location } \\
\text { of } \\
\text { scour }\end{array}$ & $\begin{array}{l}\text { Observed } \\
\text { scour depth } \\
\text { (feet) }\end{array}$ & $\begin{array}{l}\text { a Length of } \\
\text { embankment } \\
\text { blocking } \\
\text { flow } \\
\text { (feet) }\end{array}$ & $\begin{array}{c}\text { a Average } \\
\text { depth of flow } \\
\text { blocked by } \\
\text { embankment } \\
\text { (feet) }\end{array}$ & $\begin{array}{l}{ }^{\text {a }} \text { Average velocity } \\
\text { of flow blocked } \\
\text { by embankment } \\
\text { (feet per second) }\end{array}$ \\
\hline Cherokee & S-348 & Buffalo Creek & Left abutment & 0.0 & 84 & 5.6 & 2.6 \\
\hline Cherokee & S-348 & Buffalo Creek & Right abutment & 2.0 & 375 & 5.6 & 0.9 \\
\hline Laurens & $\mathrm{S}-36$ & Reedy River & Left abutment & 5.2 & 347 & 11.0 & 1.6 \\
\hline Laurens & S-112 & Enoree River & Right abutment & 1.7 & 110 & 3.2 & 0.5 \\
\hline Newberry & S-81 & Enoree River & Right abutment & 13.7 & 606 & 10.5 & 1.2 \\
\hline Spartanburg & S.C. 146 & Enoree River & Left abutment & 0.0 & 187 & 4.3 & 1.1 \\
\hline Spartanburg & S.C. 146 & Enoree River & Right abutment & 3.1 & 119 & 5.0 & 1.2 \\
\hline
\end{tabular}

\footnotetext{
${ }^{\mathrm{a}}$ Determined from the Water-Surface Profile (WSPRO) model (Shearman, 1990) with the 100-year flow.
}

\section{Road S-348 Crossing Buffalo Creek in Cherokee County}

During the investigation of clear-water abutment and contraction scour in South Carolina (Benedict, 2003), surface sediments at Road S-348 crossing Buffalo Creek in Cherokee County were described as a cohesive clayey soil with some sand content. The median grain size for a grab sample of the surface soil taken during the previous investigation was 0.131 $\mathrm{mm}$, and the soil at the bottom of the scour hole was noted to be similar. The boring descriptions on the SCDOT bridge plans (Docket Number 11.398.1) also indicate a soil consisting of clay and sand. Four Shelby tube samples for determining the soil erosion rate in the EFA were collected on August 2, 2004, including one sample near the low point of the abutment scour hole and three on the upstream flood plain. The Illinois Department of Transportation conducted the EFA tests. Figures E-3 through E-6 provide photographs, a topographic map of the site, a sketch showing the approximate location where soil samples were collected, and selected soil erosion rates based on the EFA tests. Table E-4 provides a description of the soil samples at the time of the site visit. The Illinois Department of

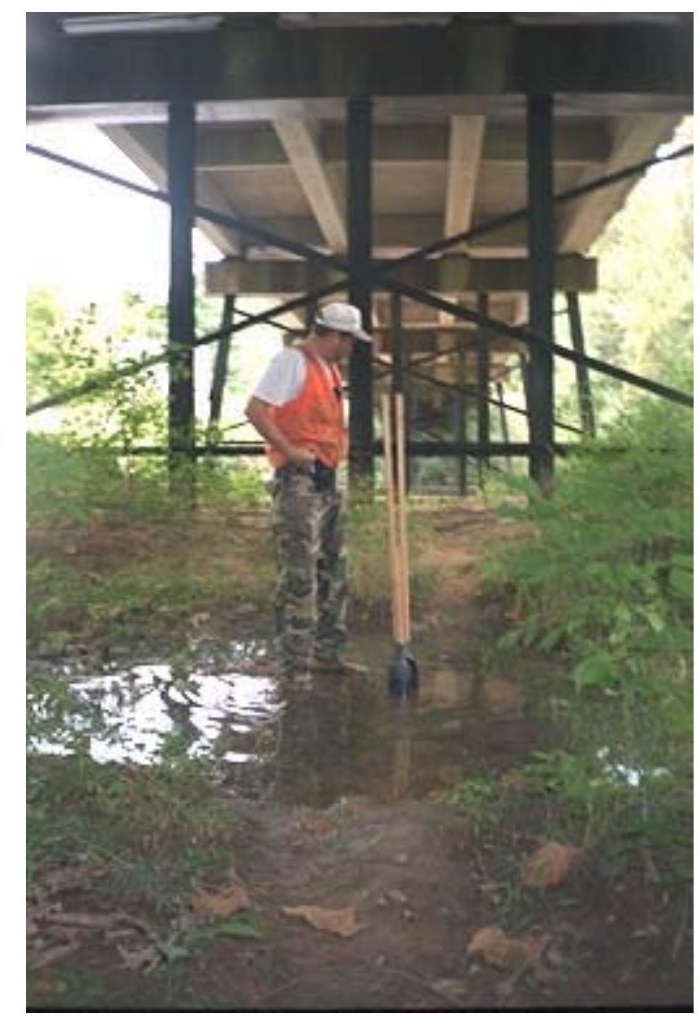

Figure E-3. Abutment scour on right overbank as viewed from the right at structure 117034800100 on Road S-348 crossing Buffalo Creek in Cherokee County, South Carolina (photograph from files of the U.S. Geological Survey, South Carolina Water Science Center, October 8, 1996). 


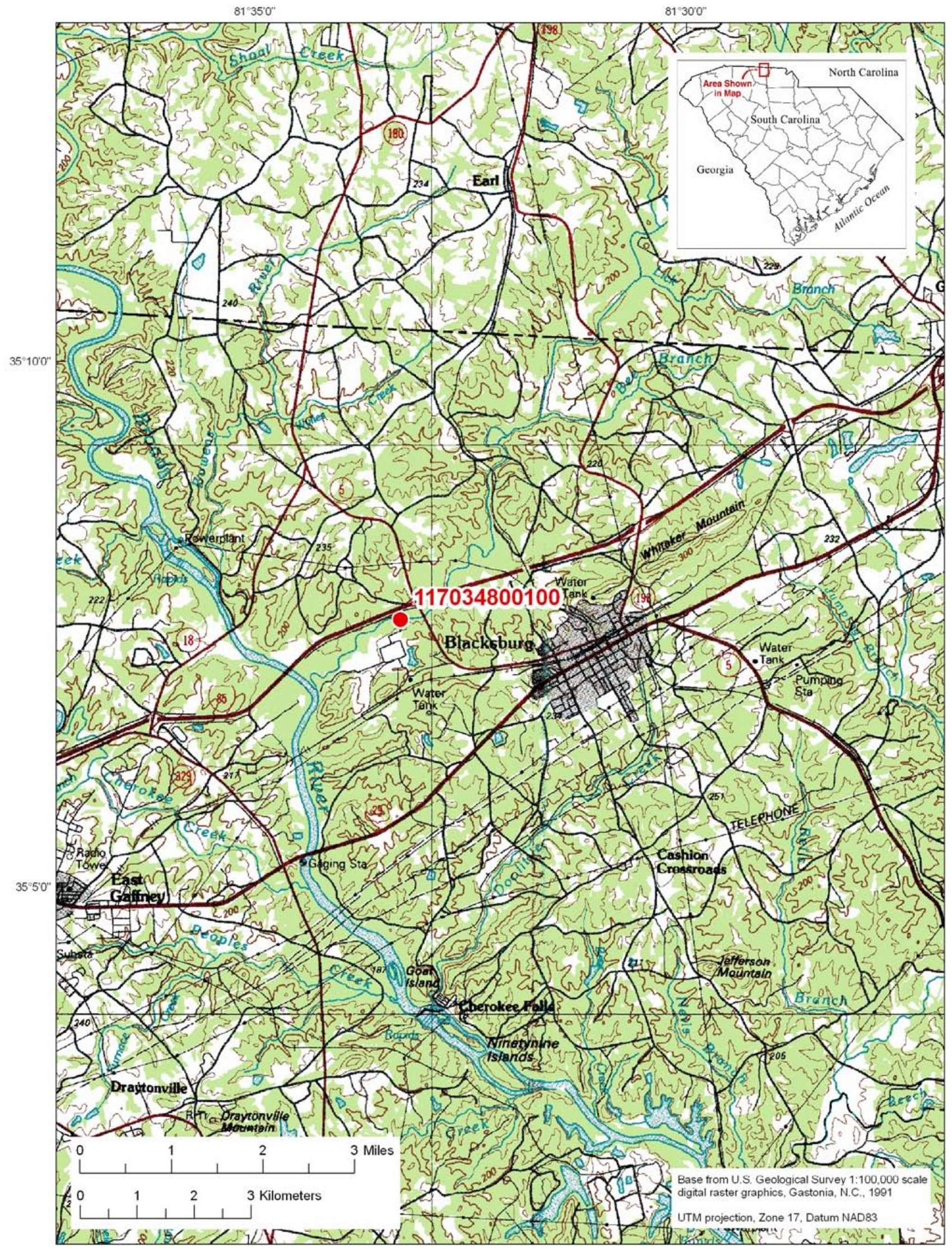

Figure E-4. Topographic map of bridge number 117034800100 on Road S-348 crossing Buffalo Creek in Cherokee County, South Carolina. 


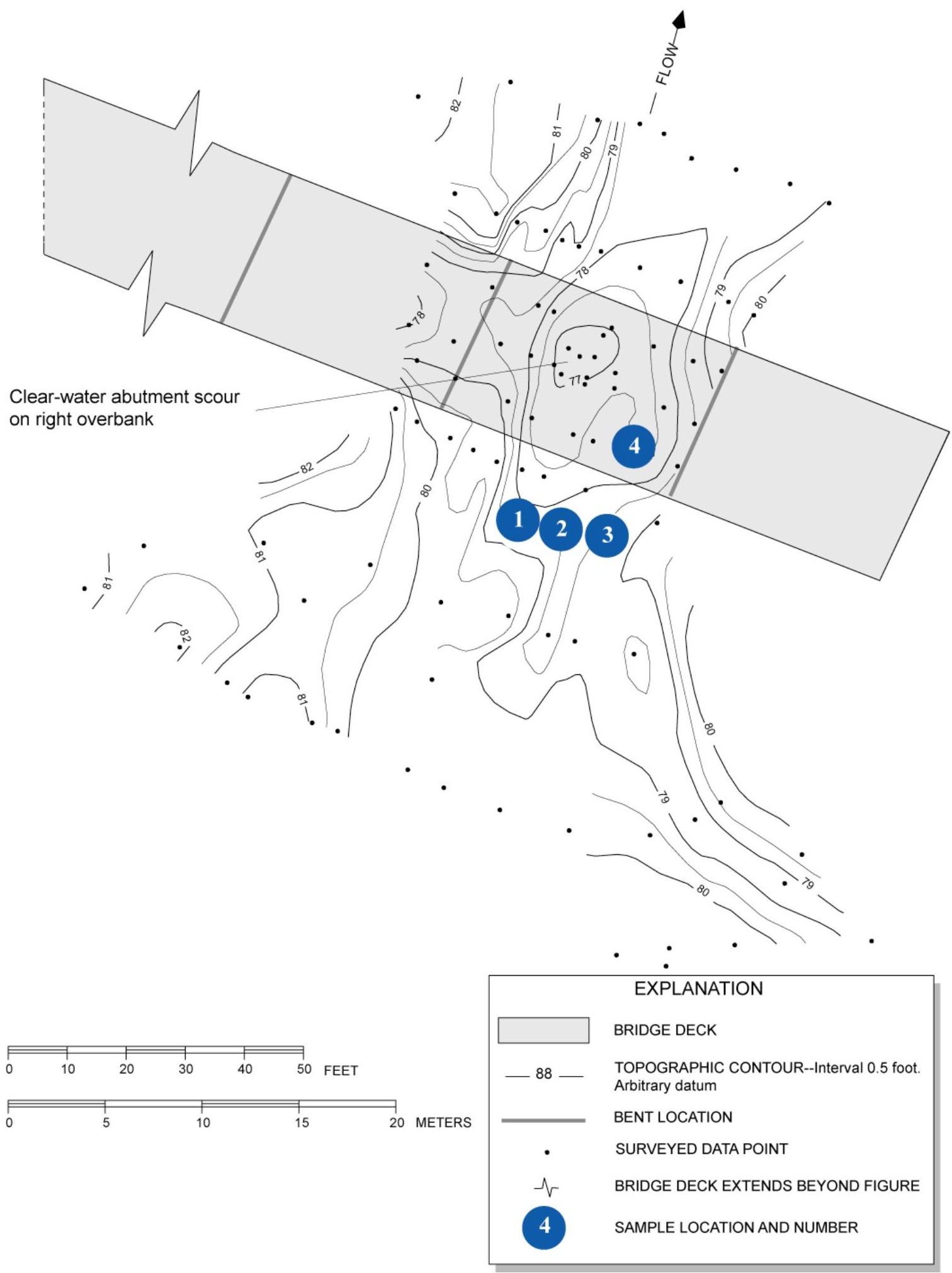

Figure E-5. Topography of scour hole and approximate location of soil samples collected at structure 117034800100 on Road S-348 crossing Buffalo Creek in Cherokee County, South Carolina. 


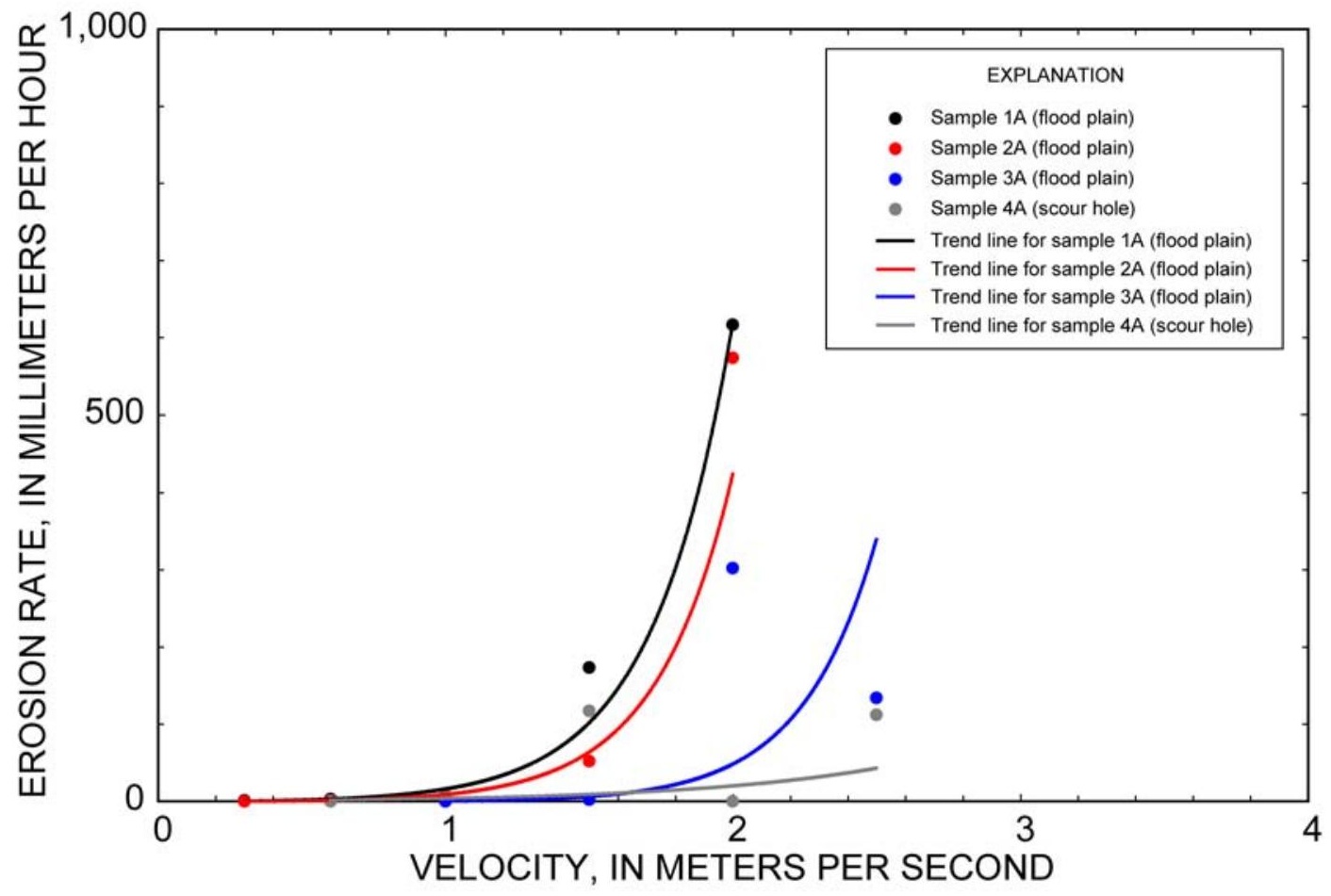

Figure E-6. Soil erosion rates based on selected EFA tests at structure 117034800100 on Road S-348 crossing Buffalo Creek in Cherokee County, South Carolina.

Transportation provided soil descriptions, a description of the EFA test procedures, and test results for each sample that can be found at the following http://pubs.water.usgs.gov/ofr03-295/data.html\#EFA .

Table E-4. Field description of Shelby tube soil samples collected at structure 117034800100 on Road S-348 crossing Buffalo Creek in Cherokee County, South Carolina.

\begin{tabular}{ccccc}
\hline $\begin{array}{c}\text { Sample } \\
\text { number } \\
\text { (fig. E-5) }\end{array}$ & $\begin{array}{c}\text { General } \\
\text { location of } \\
\text { sample }\end{array}$ & $\begin{array}{c}\text { Length of } \\
\text { sample in } \\
\text { Shelby tube } \\
\text { (inches) }\end{array}$ & $\begin{array}{c}\text { General description } \\
\text { of soil at } \\
\text { top of tube }\end{array}$ & $\begin{array}{c}\text { General description } \\
\text { of soil at } \\
\text { bottom of tube }\end{array}$ \\
\hline 1 & $\begin{array}{c}\text { Upstream } \\
\text { flood plain }\end{array}$ & 23 & Silty clay & Medium sand \\
\hline 2 & $\begin{array}{c}\text { Upstream } \\
\text { flood plain } \\
\text { Upstream } \\
\text { flood plain }\end{array}$ & 28 & Silty clay & Dense silty clay \\
4 & Scour hole & 28 & Silty clay & Dense sandy clay \\
\hline
\end{tabular}

At the time of the soil sampling for the current investigation (2004), the bridge was under private ownership. Previous USGS investigations of scour used the old SCDOT structure number 117034800100 to identify this site, and to maintain continuity between the various studies, the old SCDOT structure number also was used in the current investigation. 


\section{Road S-36 Crossing Reedy River in Laurens County}

During the investigation of clear-water abutment and contraction scour in South Carolina (Benedict, 2003), surface sediments at Road S-36 crossing Reedy River in Laurens County were described as clays and sands with occasional soil layers where sand content was substantially increased. Soil characteristics varied vertically and laterally, appearing to be a mixture of alluvium deposits. The median grain size for a grab sample of the surface soil collected during the previous investigation was $0.062 \mathrm{~mm}$. The median grain size for a grab sample taken in the same investigation at the bottom of the scour hole was $0.225 \mathrm{~mm}$. The boring descriptions on the SCDOT bridge plans (File Number 30.501) describe the surface soil as a tan, silty sand with clay and mica. Five Shelby tube samples for determining the soil erosion rates in the EFA were collected on March 6, 2004. Three of these were pushed samples obtained with the Geoprobe. The other two were driven samples obtained with a coring device that has a 140-pound hammer. The driven samples were obtained in close proximity to the pushed samples for comparison. The pushed samples are designated as samples 1 though 3 , and the driven samples correspond to pushed samples 1 and 3 and are designated 1A and 3A. Samples 1, 1A, and 2 were collected on the upstream flood plain, and samples 3 and 3A were obtained on the side wall of the scour hole. EFA tests were conducted by Texas A\&M University. Figures E-7 through E-11 provide photographs, a topographic map of the site, a sketch showing the approximate location where soil samples were collected, and selected soil erosion rates based on the EFA tests. Table E-5 provides a description of the soil samples at the time of the site visit. Texas A\&M University provided a description of the EFA test procedures and test results for each sample that can be found at the following http://pubs.water.usgs.gov/ofr03-295/data.html\#EFA .

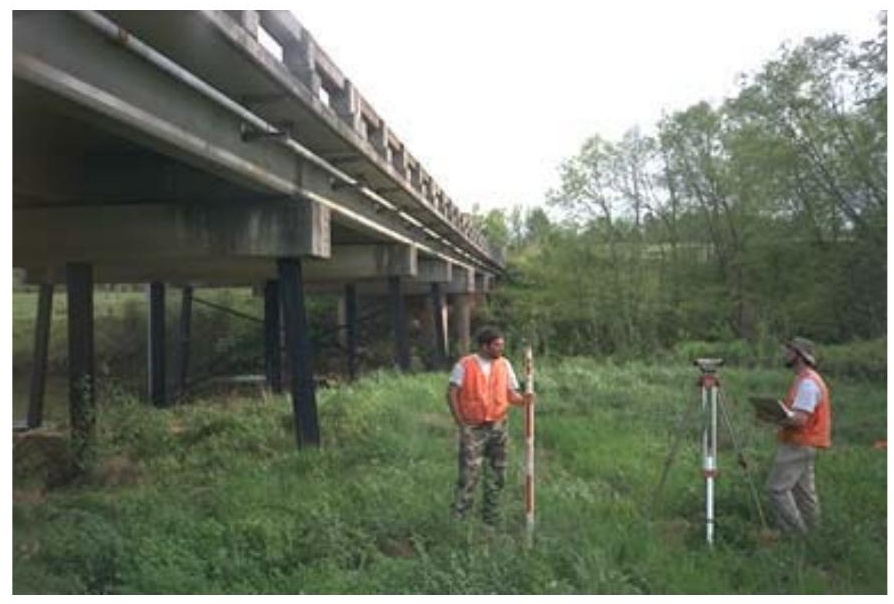

Figure E-7. Upstream face of structure 307003600200 as viewed from the left on Road S-36 crossing the Reedy River in Laurens County, South Carolina (photograph from files of the U.S. Geological Survey, South Carolina Water Science Center, April 8, 1997).

Figure E-8. Left abutment scour as viewed from downstream at structure 307003600200 on Road S-36 crossing the Reedy River in Laurens County, South Carolina (photograph from files of the U.S. Geological Survey, South Carolina Water Science Center, April 8, 1997).

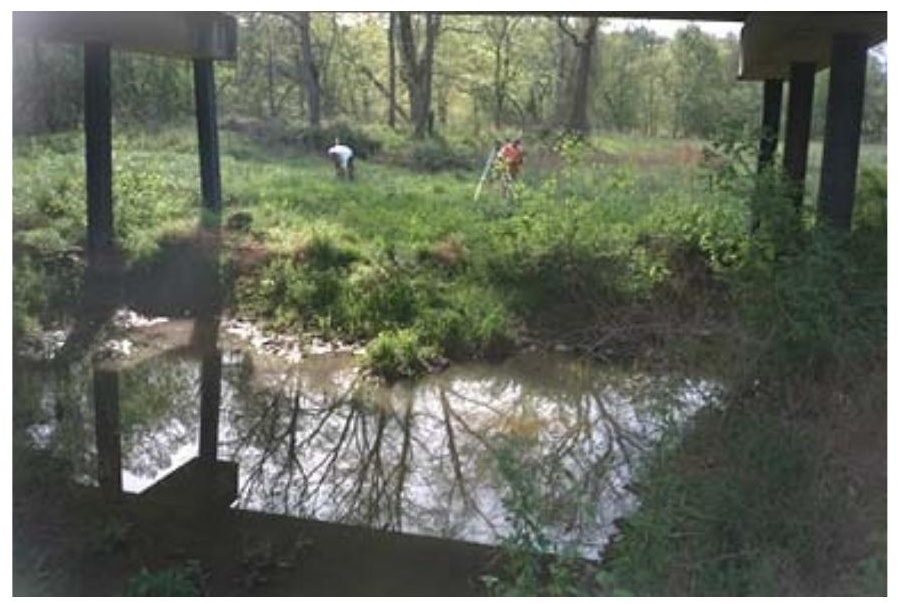




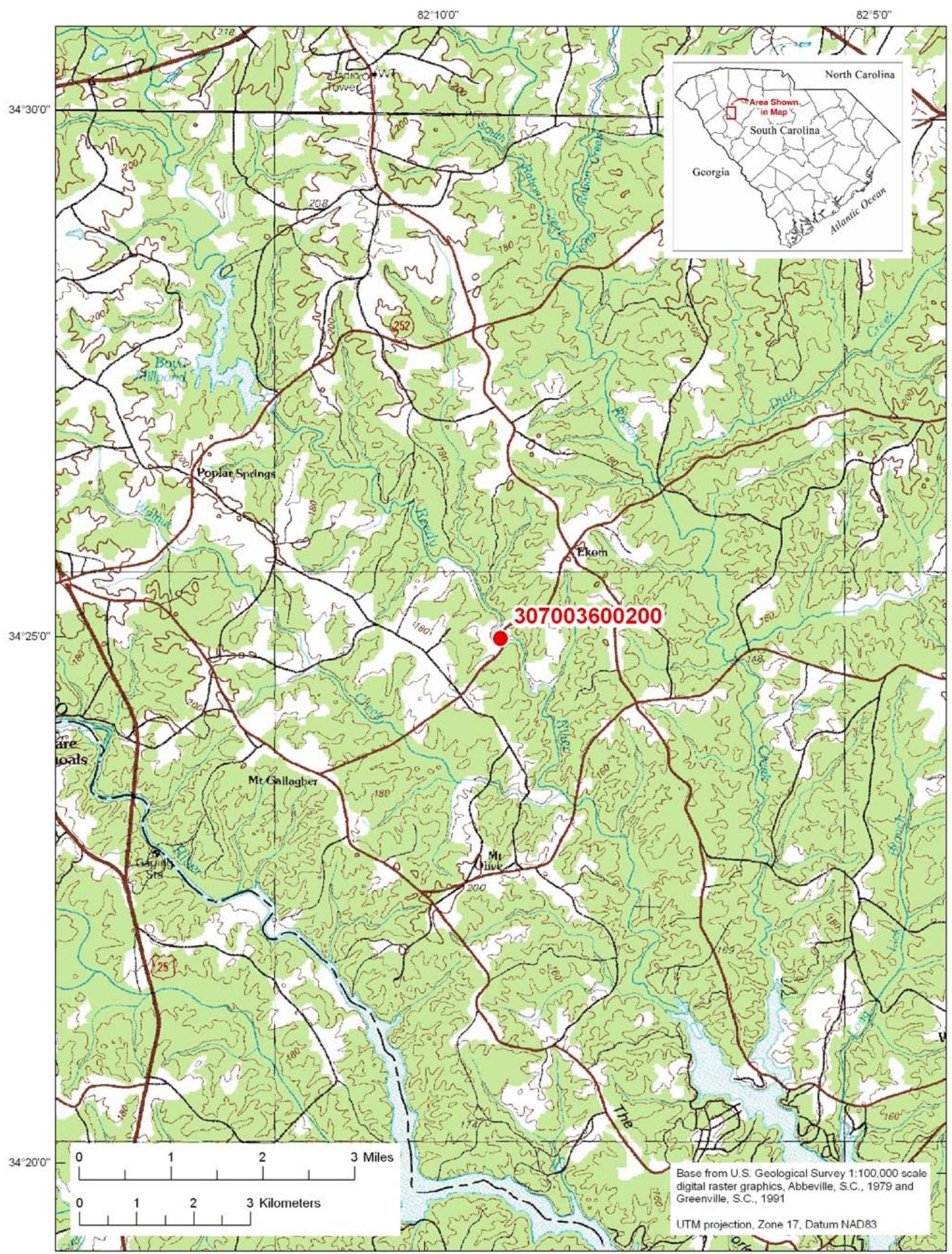

Figure E-9. Topographic map of bridge number 307003600200 on Road S-36 crossing the Reedy River in Laurens County, South Carolina. 


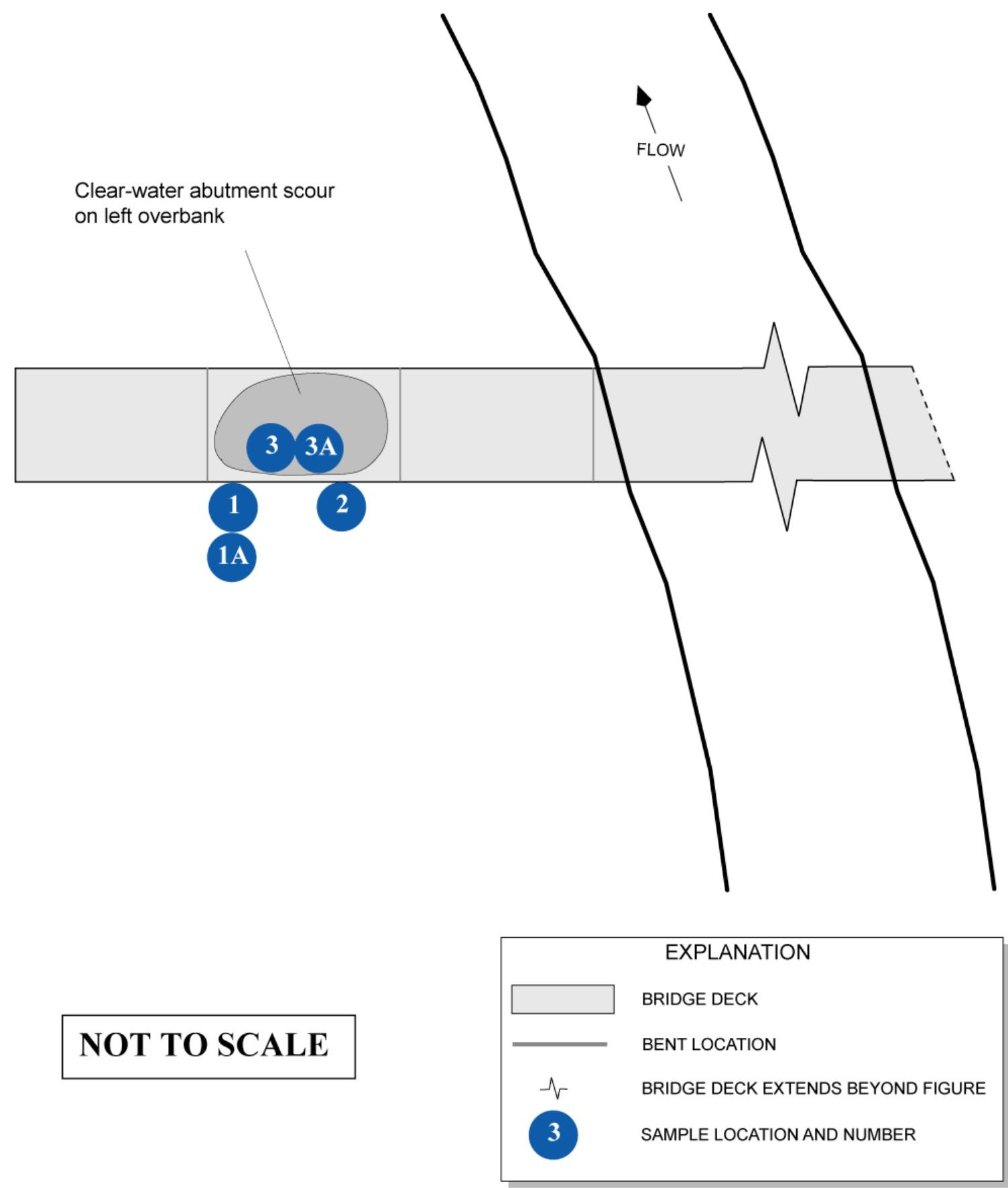

Figure E-10. Approximate plan view and location of soil samples collected at structure 307003600200 on Road S-36 crossing the Reedy River in Laurens County, South Carolina. 


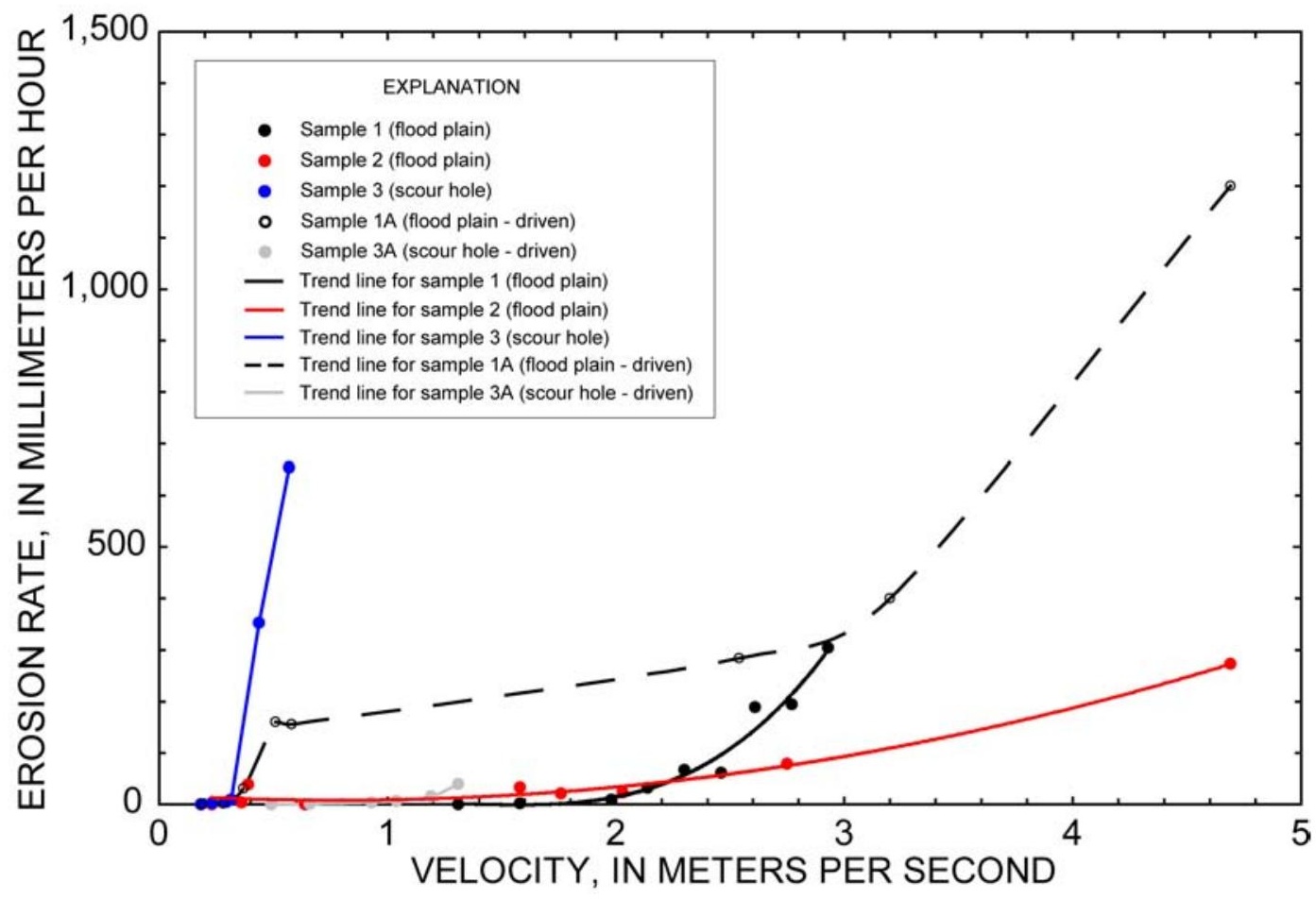

Figure E-11. Soil erosion rates based on selected EFA tests at structure 307003600200 on Road S-36 crossing the Reedy River in Laurens County, South Carolina.

Table E-5. Field description of Shelby tube soil samples collected at structure 307003600200 on Road S-36 crossing the Reedy River in Laurens County, South Carolina.

\begin{tabular}{ccccc}
\hline $\begin{array}{c}\text { Sample } \\
\text { number } \\
\text { (fig. E-10) }\end{array}$ & $\begin{array}{c}\text { General } \\
\text { location of } \\
\text { sample }\end{array}$ & $\begin{array}{c}\text { Length of } \\
\text { sample in } \\
\text { Shelby tube } \\
\text { (inches) }\end{array}$ & $\begin{array}{c}\text { General description } \\
\text { of soil at } \\
\text { top of tube }\end{array}$ & $\begin{array}{c}\text { General description } \\
\text { of soil at } \\
\text { bottom of tube }\end{array}$ \\
\hline 1 & $\begin{array}{c}\text { Upstream } \\
\text { flood plain } \\
\text { Upstream } \\
\text { flood plain } \\
\text { Upstream } \\
\text { flood plain }\end{array}$ & 26 & Silty clay & Medium to coarse sand \\
2 & 22 & Silty clay & Medium to coarse sand \\
3 & Scour hole & 27 & Silty sandy clay & Moist silty clay \\
$3 \mathrm{~A}$ & Scour hole & 20 & Silty sandy clay & Clayey sand \\
\hline
\end{tabular}




\section{Road S-112 Crossing the Enoree River in Laurens County}

During the investigation of clear-water abutment and contraction scour in South Carolina (Benedict, 2003), surface sediments at Road S-112 crossing the Enoree River in Laurens County were described as having sands and clays with alternating layers where sand content varied substantially. The median grain size for a grab sample of the surface soil collected during the previous investigation was $0.064 \mathrm{~mm}$, and the soil at the bottom of the scour hole was noted to be similar to that of the surface soils. The boring descriptions on the SCDOT bridge plans (Docket Number 3042.395) describe the soil as a gray, fine to medium grain sand with a trace of clay. Three Shelby tube samples for determining the soil erosion rates in the EFA were collected on October 20, 2004, including one sample near the low point of the abutment scour hole and two on the upstream flood plain. EFA tests were conducted by the North Carolina Department of Transportation. Figures E-12 through E-16 provide photographs, a topographic map of the site, a sketch showing the approximate location where soil samples were collected, and selected soil erosion rates based on the EFA tests. Table E-6 provides a description of the soil samples at the time of the site visit. The North Carolina Department of Transportation provided soil descriptions, a description of the EFA test procedures, and test results for each sample that can be found at the following http://pubs.water.usgs.gov/ofr03-295/data.html\#EFA .

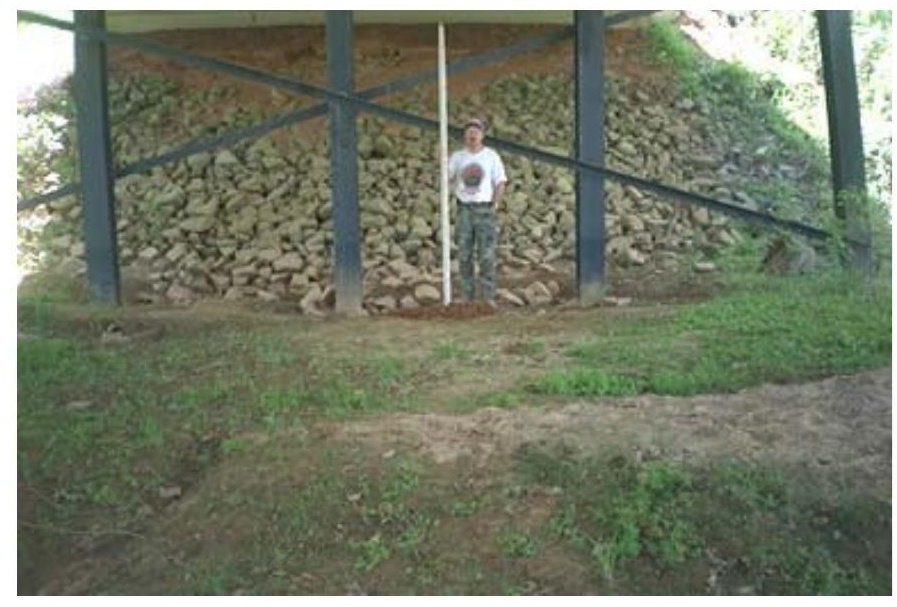

Figure E-12. Right abutment as viewed from the left at structure 307011200100 on Road S-112 crossing the Enoree River in Laurens County, South Carolina (photograph from files of the U.S. Geological Survey, South Carolina Water Science Center, April 2, 1997).

Figure E-13. Right abutment as viewed from the left at structure 307011200100 on Road S-112 crossing the Enoree River in Laurens County, South Carolina (photograph from files of the U.S. Geological Survey, South Carolina Water Science Center, April 2, 1997).

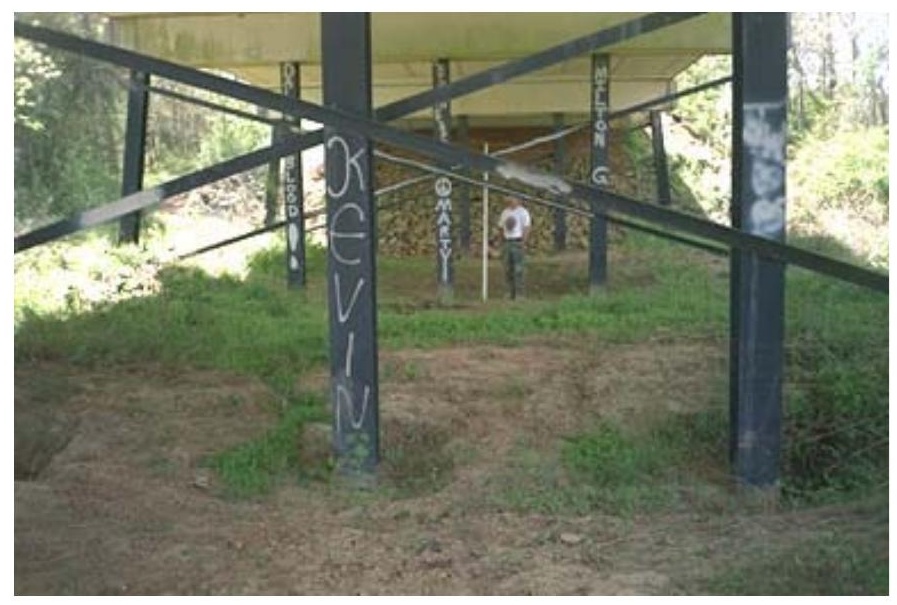




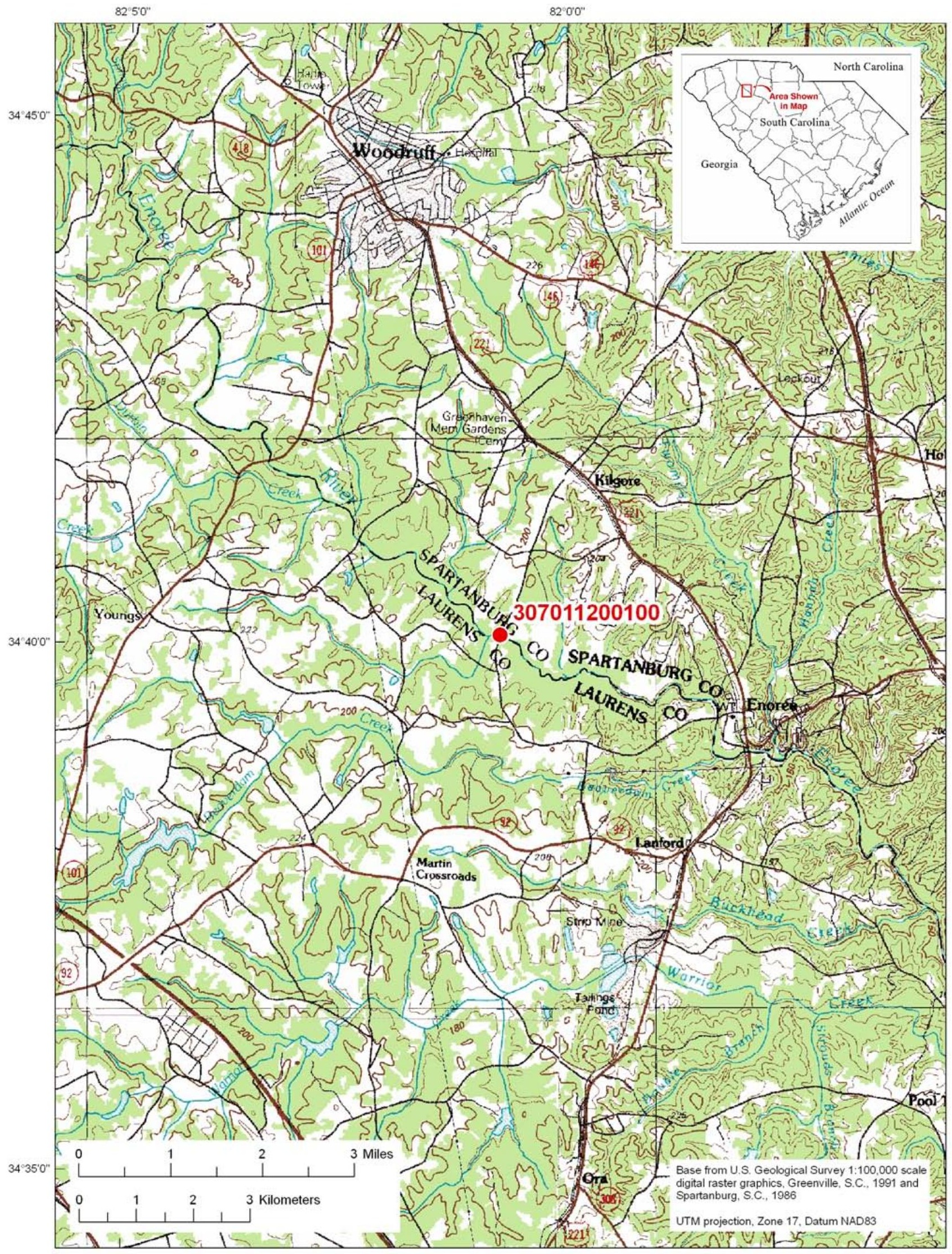

Figure E-14. Topographic map of structure number 307011200100 on Road S-112 crossing the Enoree River in Laurens County, South Carolina. 


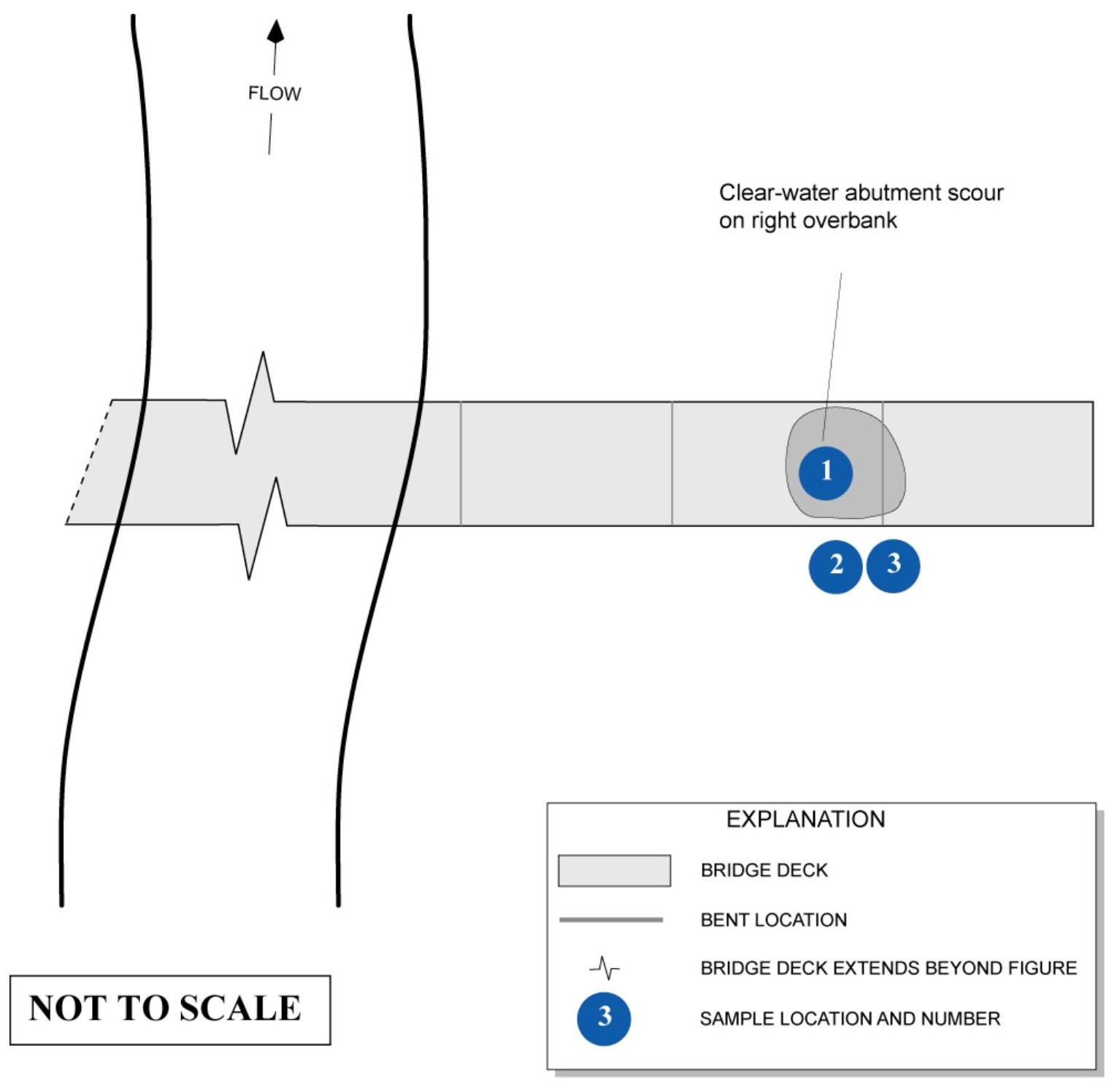

Figure E-15. Approximate plan view and location of soil samples collected at structure 307011200100 on Road S-112 crossing the Enoree River in Laurens County, South Carolina. 


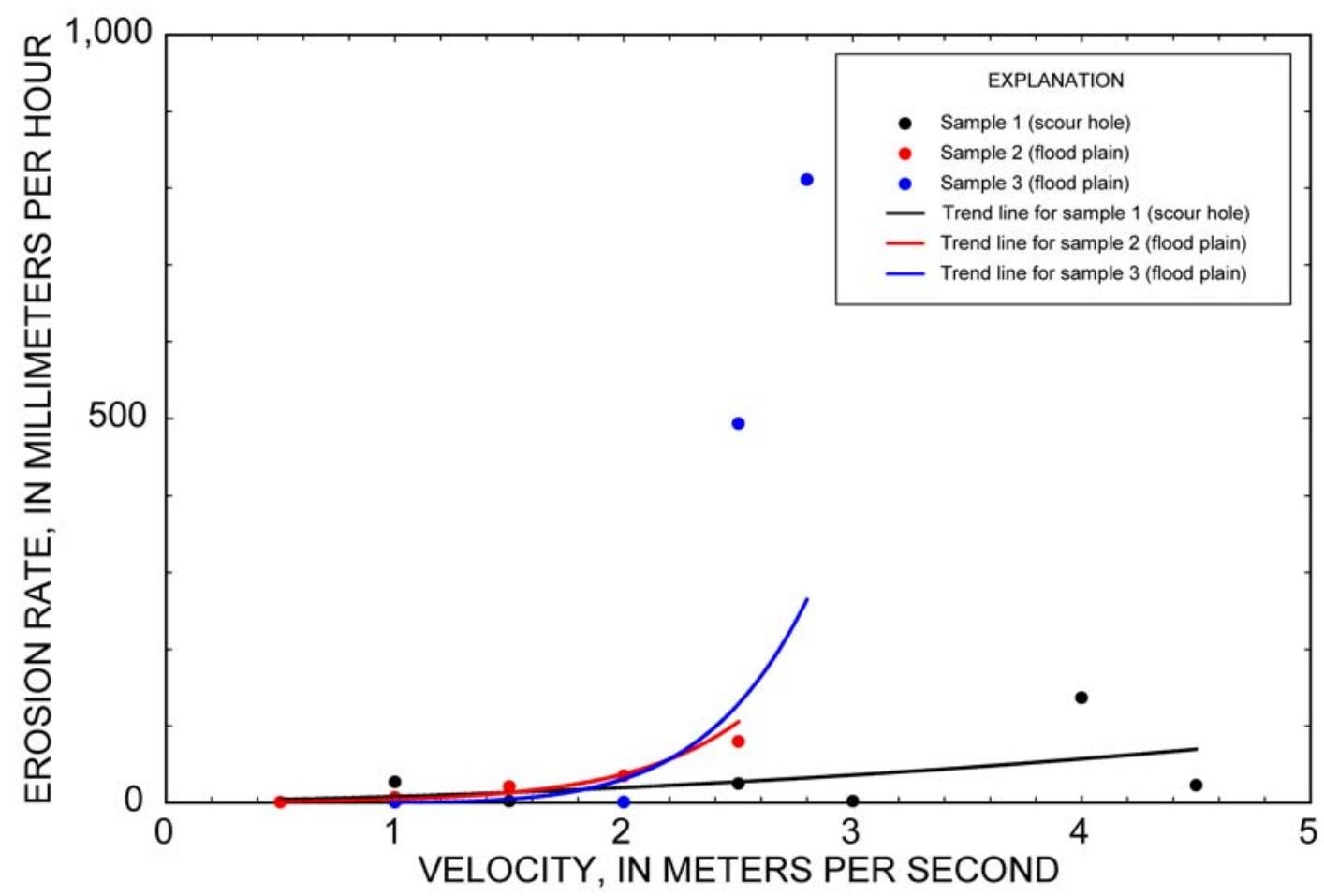

Figure E-16. Soil erosion rates based on selected EFA tests at structure 307011200100 on Road S-112 crossing the Enoree River in Laurens County, South Carolina.

Table E-6. Field description of Shelby tube soil samples collected at structure 307011200100 on Road S-112 crossing the Enoree River in Laurens County, South Carolina.

\begin{tabular}{ccccc}
\hline $\begin{array}{c}\text { Sample } \\
\text { number } \\
\text { (fig. E-15) }\end{array}$ & $\begin{array}{c}\text { General location of } \\
\text { sample }\end{array}$ & $\begin{array}{c}\text { Length of } \\
\text { sample in } \\
\text { Shelby tube } \\
\text { (inches) }\end{array}$ & $\begin{array}{c}\text { General description } \\
\text { of soil at } \\
\text { top of tube }\end{array}$ & $\begin{array}{c}\text { General description } \\
\text { of soil at } \\
\text { bottom of tube }\end{array}$ \\
\hline 1 & Scour hole & 28 & Silty sandy clay & Silty sandy clay \\
2 & Upstream flood plain & 17 & Silty clay & Silty sandy clay \\
\hline & Upstream flood plain & 27 & Silty clay & Silty clay \\
\hline
\end{tabular}




\section{Road S-81 Crossing the Enoree River in Newberry County}

During the investigation of clear-water abutment and contraction scour in South Carolina (Benedict, 2003), surface sediments at Road S-81 crossing the Enoree River in Newberry County were described as having sands, silts, and clays with alternating layers where sand content varied substantially. The median grain size for a grab sample of the surface soil collected during the previous investigation was $0.122 \mathrm{~mm}$. The median grain size for a grab sample collected in the same investigation at the bottom of the scour hole was $0.318 \mathrm{~mm}$. The boring descriptions on the SCDOT bridge plans (Docket Number 36.395) describe the surface soil as a tan, silty sand with some clay. Six Shelby tube samples for determining the soil erosion rates in the EFA were collected on June 7, 2004. The large depth of the abutment-scour hole prohibited access with the Geoprobe, and therefore, no sample was taken in the scour hole. EFA tests were conducted by the Minnesota Department of Transportation. Figures E-17 through E-20 provide photographs, a topographic map of the site, and a sketch showing the approximate location where soil samples were collected. (The Minnesota Department of Transportation had a computer failure during EFA tests, and attempts are being made to retrieve these data. At the time of publication, these data were not available. If the data are retrieved, electronic spreadsheets with these data will be posted with the other EFA data.) Table E-7 provides a description of the soil samples at the time of the site visit.

Figure E-17. Right abutment scour as viewed from downstream at structure 367008100200 on Road S-81 crossing the Enoree River in Newberry County, South Carolina (photograph from files of the U.S. Geological Survey, South Carolina Water Science Center, April 7, 1997).
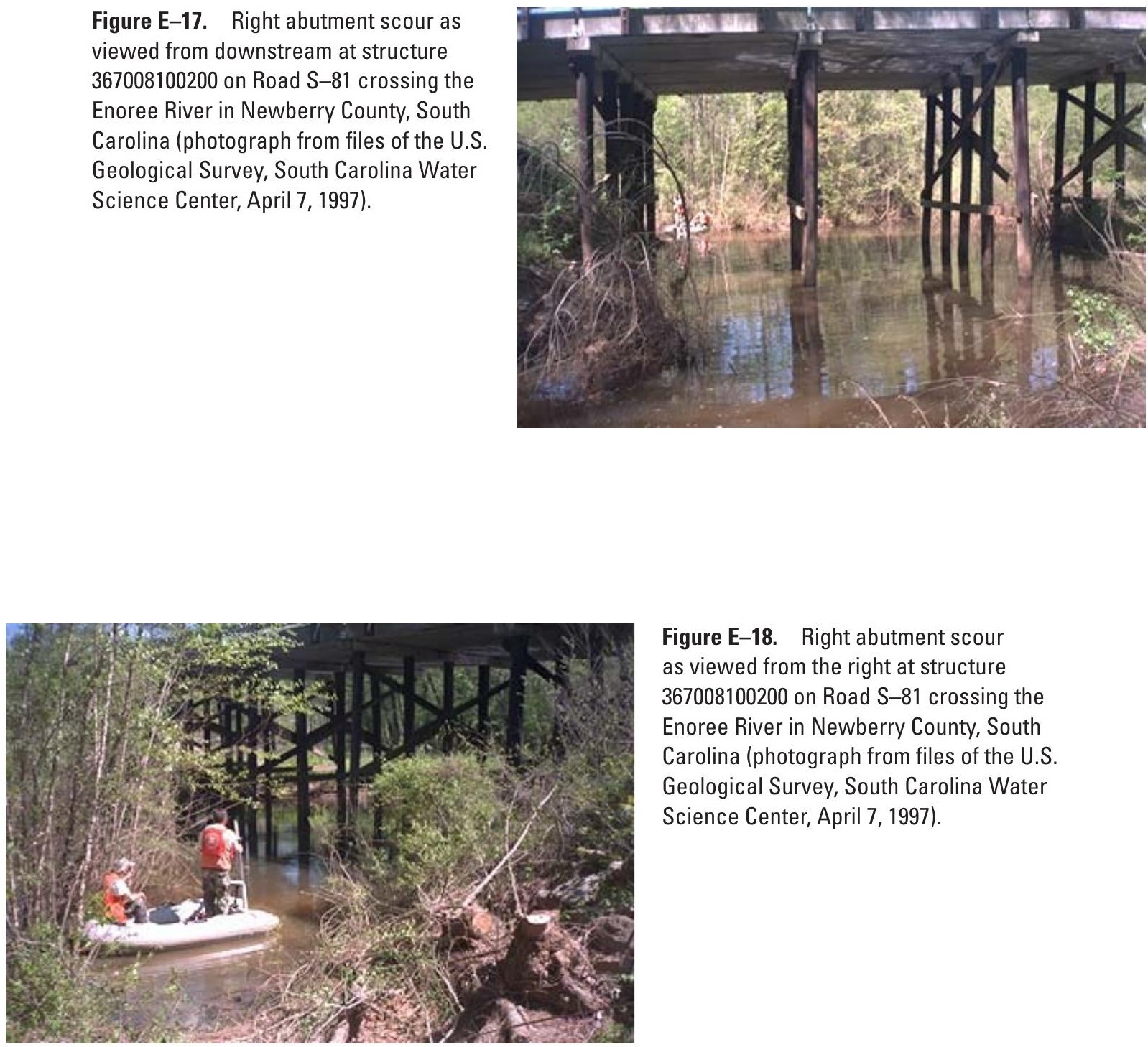

Figure E-18. Right abutment scour as viewed from the right at structure 367008100200 on Road S-81 crossing the Enoree River in Newberry County, South Carolina (photograph from files of the U.S. Geological Survey, South Carolina Water Science Center, April 7, 1997). 




Figure E-19. Topographic map of bridge number 367008100200 on Road S-81 crossing the Enoree River in Newberry County, South Carolina. 

on right overbank
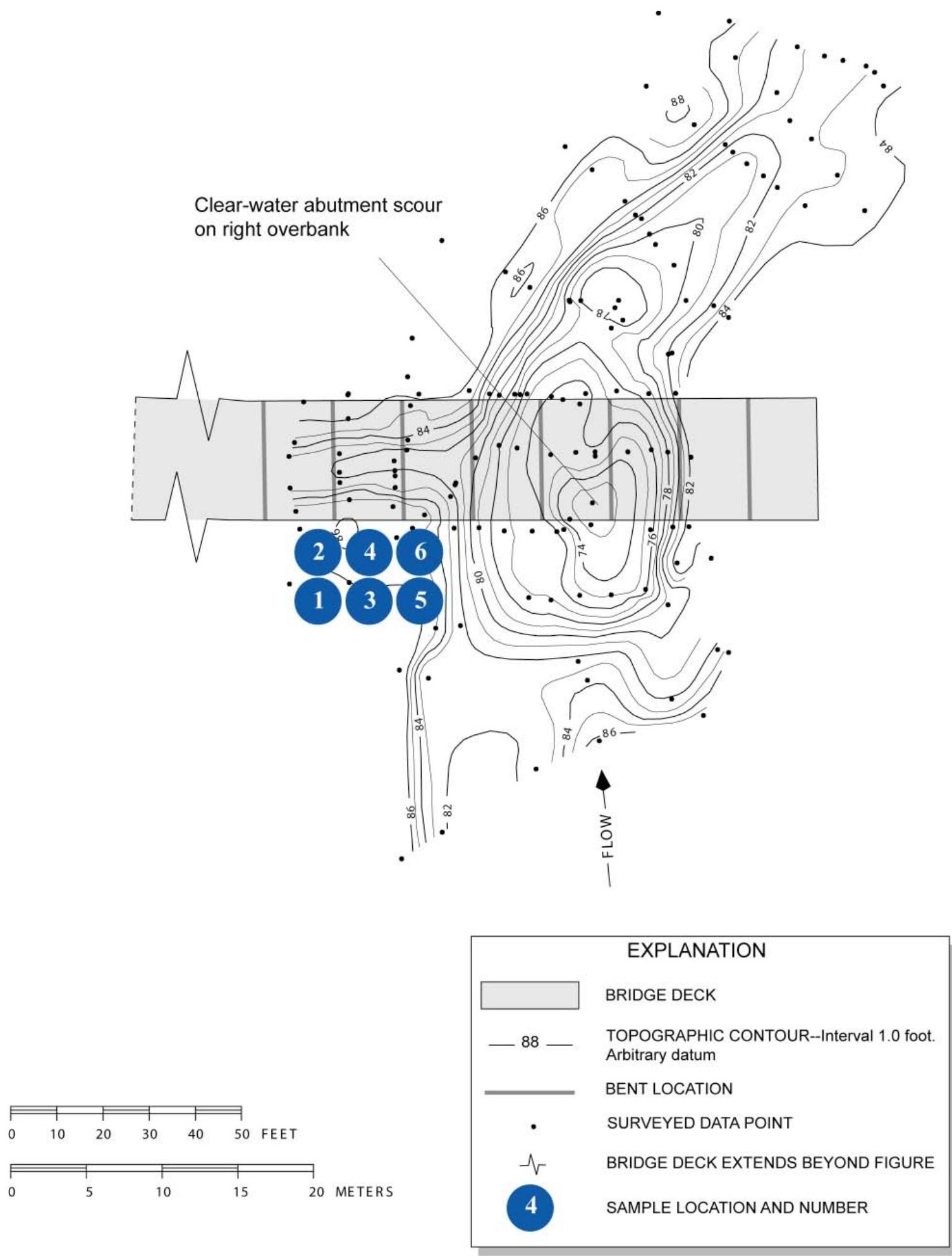

Figure E-20. Topography of scour hole and approximate location of soil samples collected at structure 367008100200 on Road S-81 crossing the Enoree River in Newberry County, South Carolina. 
Table E-7. Field description of Shelby tube soil samples collected at structure 367008100200 on Road S-81 crossing the Enoree River in Newberry County, South Carolina.

\begin{tabular}{ccccc}
\hline $\begin{array}{c}\text { Sample } \\
\text { number } \\
\text { (fig. E-20) }\end{array}$ & $\begin{array}{c}\text { General location of } \\
\text { sample }\end{array}$ & $\begin{array}{c}\text { Length of } \\
\text { sample in } \\
\text { Shelby tube } \\
\text { (inches) }\end{array}$ & $\begin{array}{c}\text { General description } \\
\text { of soil at } \\
\text { top of tube }\end{array}$ & $\begin{array}{c}\text { General description } \\
\text { of soil at } \\
\text { bottom of tube }\end{array}$ \\
\hline 1 & Upstream flood plain & 26 & Slightly sandy clayey silt & Medium to coarse silty, clayey sand \\
3 & Upstream flood plain & 26 & Slightly sandy clayey silt & Medium to coarse silty, clayey sand \\
4 & Upstream flood plain & 27 & Slightly sandy clayey silt & Medium to coarse silty, clayey sand \\
\hline 5 & Upstream flood plain & 27 & Slightly sandy clayey silt & Medium to coarse silty, clayey sand \\
\hline & Upstream flood plain & 27 & Slightly sandy clayey silt & Medium to coarse silty, clayey sand \\
\hline
\end{tabular}




\section{Route S.C. 146 Crossing the Enoree River in Spartanburg County}

During the investigation of clear-water abutment and contraction scour in South Carolina (Benedict, 2003), surface sediments at Route S.C. 146 crossing the Enoree River in Spartanburg County were described as having sands, silts, and clays, with alternating layers where sand content varied substantially. The median grain size for a grab sample of the surface soil taken during the previous investigation was $0.216 \mathrm{~mm}$. The median grain size for a grab sample taken in the same investigation at the bottom of the scour hole was $0.069 \mathrm{~mm}$. The boring descriptions on the SCDOT bridge plans (Docket Number 2342.245) describe the surface soil as sand and clay. Four Shelby tube samples for determining the soil erosion rates in the EFA were collected on August 9, 2004, including one sample near the low point of the abutment scour hole and three on the upstream flood plain. EFA tests were conducted by the North Carolina Department of Transportation. Figures E-21 through E-25 provide photographs, a topographic map of the site, a sketch showing the approximate location where soil samples were taken, and selected soil erosion rates based on the EFA tests. Field notes for this site are missing, and therefore, no description of the soil samples at the time of the site visit is provided. The North Carolina Department of Transportation provided soil descriptions, a description of the EFA test procedures, and test results for each sample that can be found at the following http://pubs.water.usgs.gov/ofr03-295/data. html\#EFA.

Figure E-21. Right overbank as viewed from upstream at structure 424014600100 on Route S.C. 146 crossing the Enoree River in Spartanburg County, South Carolina (photograph from files of the U.S. Geological Survey, South Carolina Water Science Center, February 13, 1997).
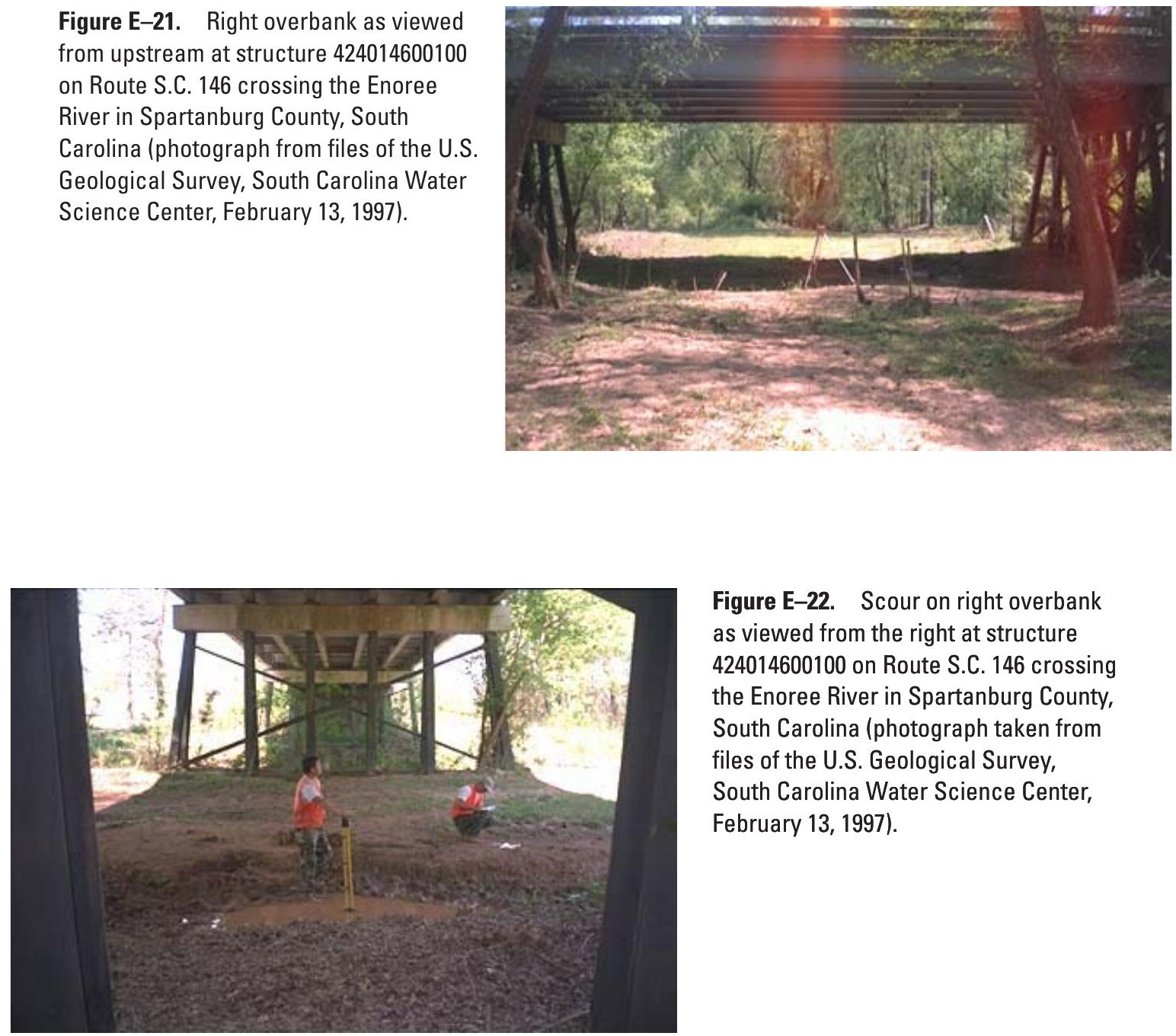

Figure E-22. Scour on right overbank as viewed from the right at structure 424014600100 on Route S.C. 146 crossing the Enoree River in Spartanburg County, South Carolina (photograph taken from files of the U.S. Geological Survey, South Carolina Water Science Center, February 13 , 1997). 


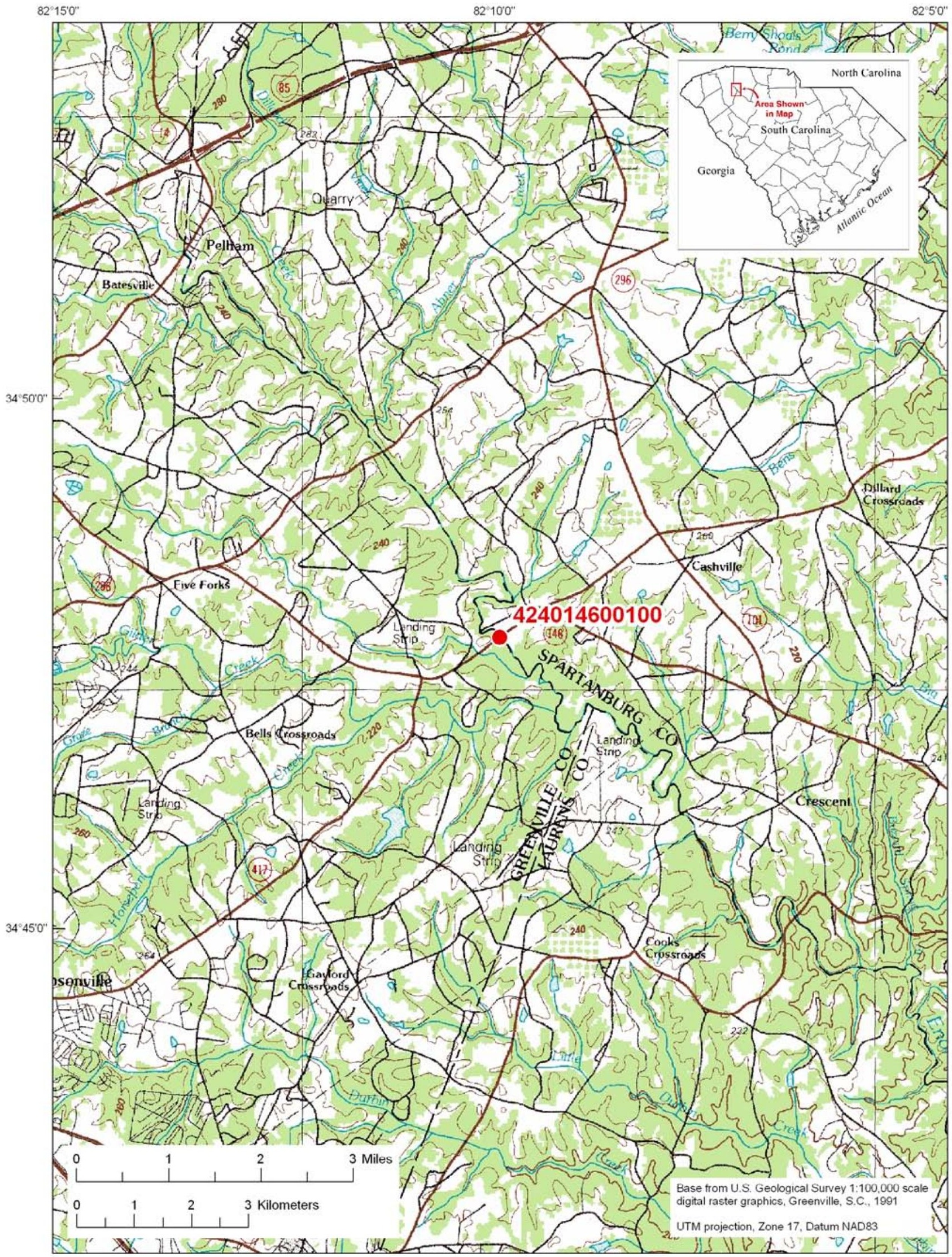

Figure E-23. Topographic map of bridge number 424014600100 on Route S.C. 146 crossing the Enoree River in Spartanburg County, South Carolina. 


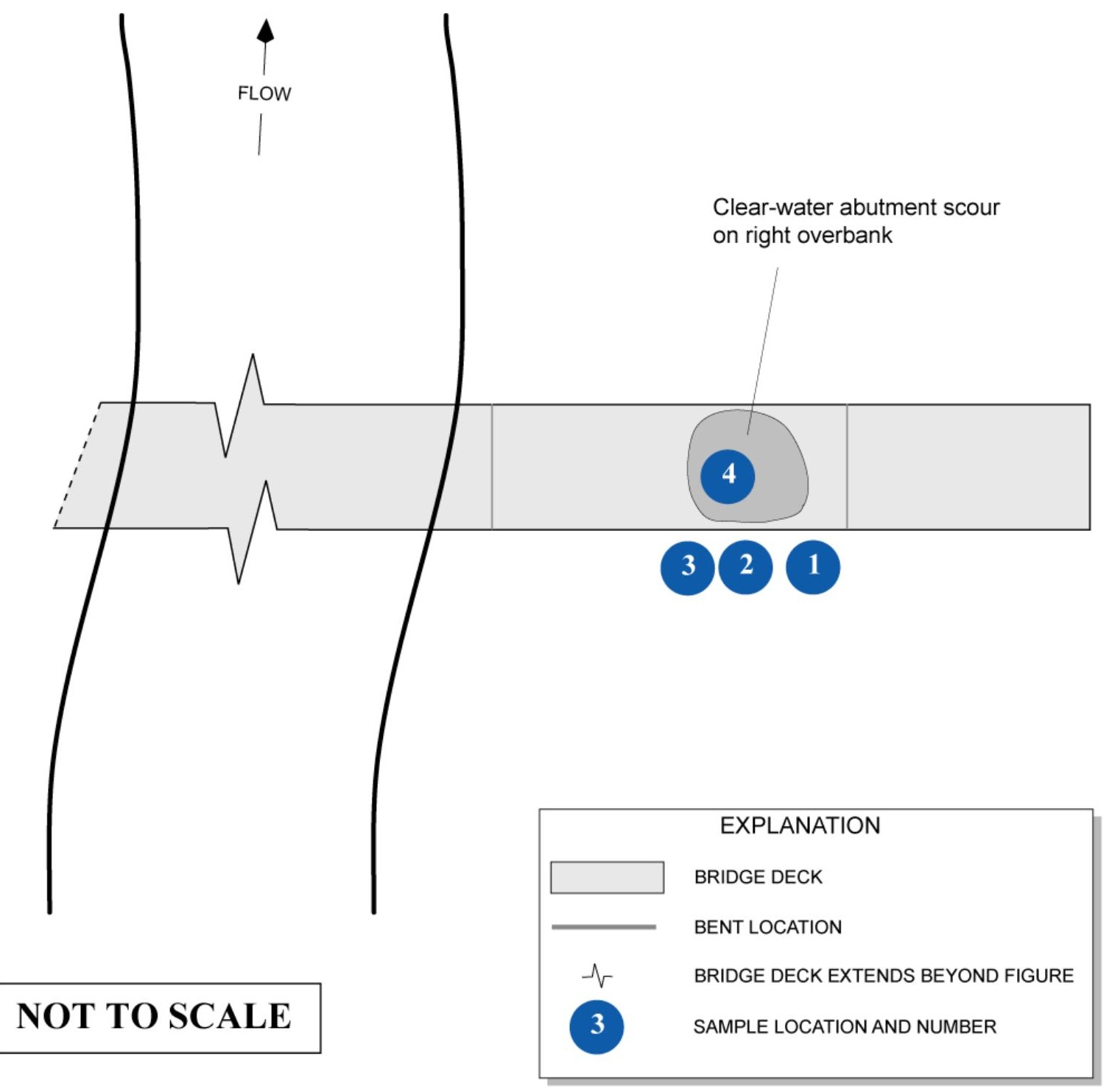

Figure E-24. Approximate plan view and location of soil samples collected at structure 424014600100 on Route S.C. 146 crossing the Enoree River in Spartanburg County, South Carolina. 


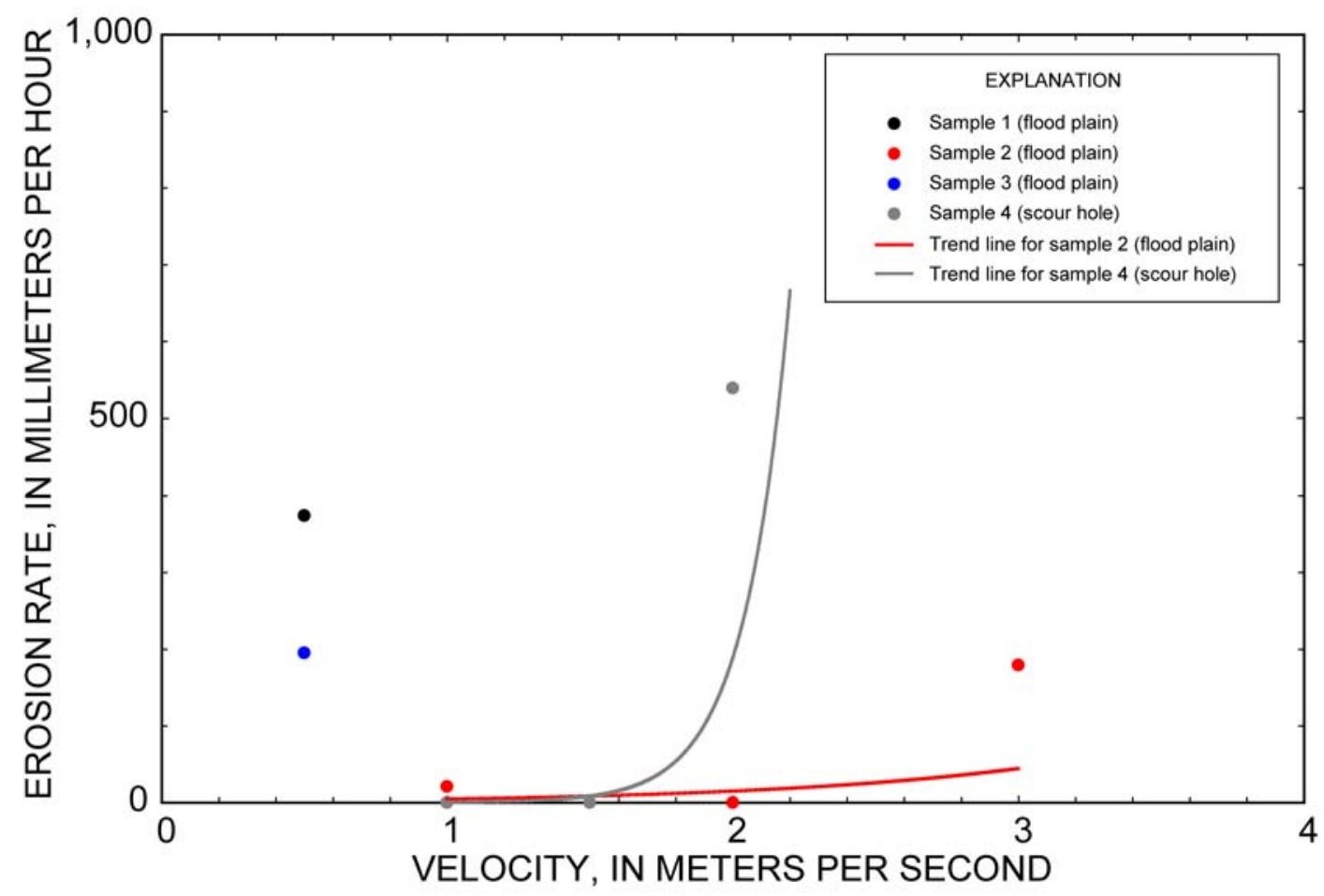

Figure E-25. Soil erosion rates based on selected EFA tests at structure 424014600100 on Route S.C. 146 crossing the Enoree River in Spartanburg County, South Carolina.

\section{Selected References}

Benedict, S.T., 2003, Clear-water abutment and contraction scour in the Coastal Plain and Piedmont Provinces of South Carolina, 1996-99: U.S. Geological Survey Water-Resources Investigations Report 03-4064, 137 p.

Benedict, S.T., and Caldwell, A.W., 2006, Development and evaluation of clear-water pier and contraction scour envelope curves in the Coastal Plain and Piedmont of South Carolina: U.S. Geological Survey Scientific Investigations Report 2005-5289, $98 \mathrm{p}$.

Benedict, S.T., Deshpande, Nikhil, Aziz, N.M., and Conrads, P.A., 2006, Trends of abutment-scour prediction equations applied to 144 field sites in South Carolina: U.S. Geological Survey Open-File Report 2003-295, 150 p.

Texas Transportation Institute, 1999, Scour and erosion prediction-Overview of EFA and SRICOS, accessed June 28, 2006, at http://tti.tamu.edu/geotech/scour/

Shearman, J.O., 1990, User's manual for WSPRO-A computer model for water-surface profile computations: Federal Highway Administration, Report FHWA-IP-89-027, 175 p. 


\section{Appendix F}

A 2-D numerical model study on flow past the abutments of highway bridges in South Carolina.

[This paper was written by Dr. Xibing S. Dou, a Senior Research Engineer for GKY and Associates, Inc., under the guidance of the Federal Highway Administration (FHWA). This paper has not been through the formal U.S. Geological Survey technical peer review, editorial preparation, and approval processes, but is provided for information only as a courtesy to the FHWA.] 


\title{
A 2-D NUMERICAL MODEL STUDY ON FLOW PAST THE ABUTMENTS OF HIGHWAY BRIDGES IN SOUTH CAROLINA
}

By Xibing S. Dou ${ }^{1}$

\begin{abstract}
A 2-D numerical model study on ten highway bridges located in South Carolina is presented in this report. The study was conducted by using CCHE2D and CCHE2D-GUI which was developed at the National Center for Computational Hydroscience and Engineering. The boundary conditions used in the study of each case were based on the 1-D WSPRO studies developed by the USGS for selected streams in South Carolina. The 2-D velocity vectors and the magnitude of velocity represented by contour lines are plotted to show the flow fields for each case. The maximum velocity near the abutment was pointed out on the plot. The geometry sketches are plotted to illustrate bridge sections. The velocity profiles for the bridge sections are plotted and compared with 1-D WSPRO results and the abutment-scour prediction model ABSCOUR. At the end of this report, introduction and demonstration of using CCHE2D-GUI was made through a case study.
\end{abstract}

\section{INTRODUCTION}

A numerical model study was conducted to simulate two-dimensional flows passing bridge crossings at ten bridges in South Carolina (Benedict, 2006). The numerical model used in the study is CCHE2D (Jia and Wang, 2001) developed by the National Center for Computational Hydroscience and Engineering (NCCHE) at the University of Mississippi. The CCHE2D (Jia and Wang, 2001) model is a twodimensional, depth-averaged, unsteady, turbulent flow model with non-uniform and nonequilibrium sediment transport capabilities. The model has three different turbulent closure schemes for a variety of flow conditions and level of accuracy. The model can handle wetting and drying nodes in the computational domain and allows the user to specify total slip, no slip, or log-law conditions at no-flow boundaries. Some of the cases in this study were computed using the newly released version: CCHE2D-GUI (Graphical User Interface; Zhang, 2005). CCHE2D-GUI is a powerful tool in simulating 2-D turbulence flows and sediment transport and was developed with user friendly pre- and

\footnotetext{
${ }^{1}$ Senior Research Engineer, GKY and Associates Inc., 5411-E Backlick Road, Springfield, VA 22151
} 
post-processing capabilities to assist experienced and novice modelers. CCHE2D-GUI (Zhang, 2005) will be introduced in this report systematically through the example case Turkey Creek@RT9 in Chester County, South Carolina.

Seven 2-D flow simulations were conducted for $\mathrm{Q}_{100}$ floods. The boundary conditions adopted in the 2-D simulations are the same as those used in the 1-D WSPRO (Shearman, 1990) studies developed by the U.S. Geological Survey (USGS) (1-D model data provided by S. Benedict, USGS, written commun., December 2003). The computed 2-D results were compared with 1-D WSPRO results. The simulated 2-D flows were also compared with the ABSCOUR (Maryland State Highway Administration (MDSHA), 2006) results estimated by the USGS and the MDSHA (Benedict and others, 2006; S. Davis, MDSHA, written commun.). The average and maximum velocities near abutment from the 2-D results were used to recalculate the local velocity factor $K_{v}$, which is used in ABSCOUR (MDSHA, 2006) to determine abutment scour depths. The ten simulated 2-D cases are listed as follows:

\begin{tabular}{|c|c|c|c|}
\hline A & Indian Creek@S32 & Newberry County & \multirow{7}{*}{$\begin{array}{l}\text { Compared with } \\
\text { ABSCOUR }\end{array}$} \\
\hline B & Cannons Creek@ @299 & Newberry County & \\
\hline $\mathrm{C}$ & Turkey Creek@SC9 & Chester County & \\
\hline $\mathrm{D}$ & Enoree River@ SC146 & Spartanburg County & \\
\hline $\mathrm{E}$ & Enoree River@ S22 & Union County & \\
\hline $\mathrm{F}$ & Enoree River@S112 & Laurens County & \\
\hline G & Reedy River@S68 & Greenville County & \\
\hline $\mathrm{H}$ & Cypress Creek@SC3 & Jasper County & \multirow{3}{*}{$\begin{array}{c}\text { No ABSCOUR } \\
\text { comparison }\end{array}$} \\
\hline I & Sparrow Swamp@ US301 & Florence County & \\
\hline $\mathrm{J}$ & Coosawhatchie River@US601 & Hampton County & \\
\hline
\end{tabular}

Table 1. Summary Table for the Cases Simulated 


\section{CASE STUDIES}

A. Indian Creek@,S32, Newberry County

$\mathrm{Q}_{100}$ Discharge (cfs):

5,360

Elevation Slope:

0.0017

W.S. Elevation at the Exit (ft):

362.36

Manning's $n$ at the Approach Section:

Simulated Channel Length (ft):

0.14/0.04/0.14 (LOB/MC/ROB)

Span at Bridge Section (ft):

Indian.S32

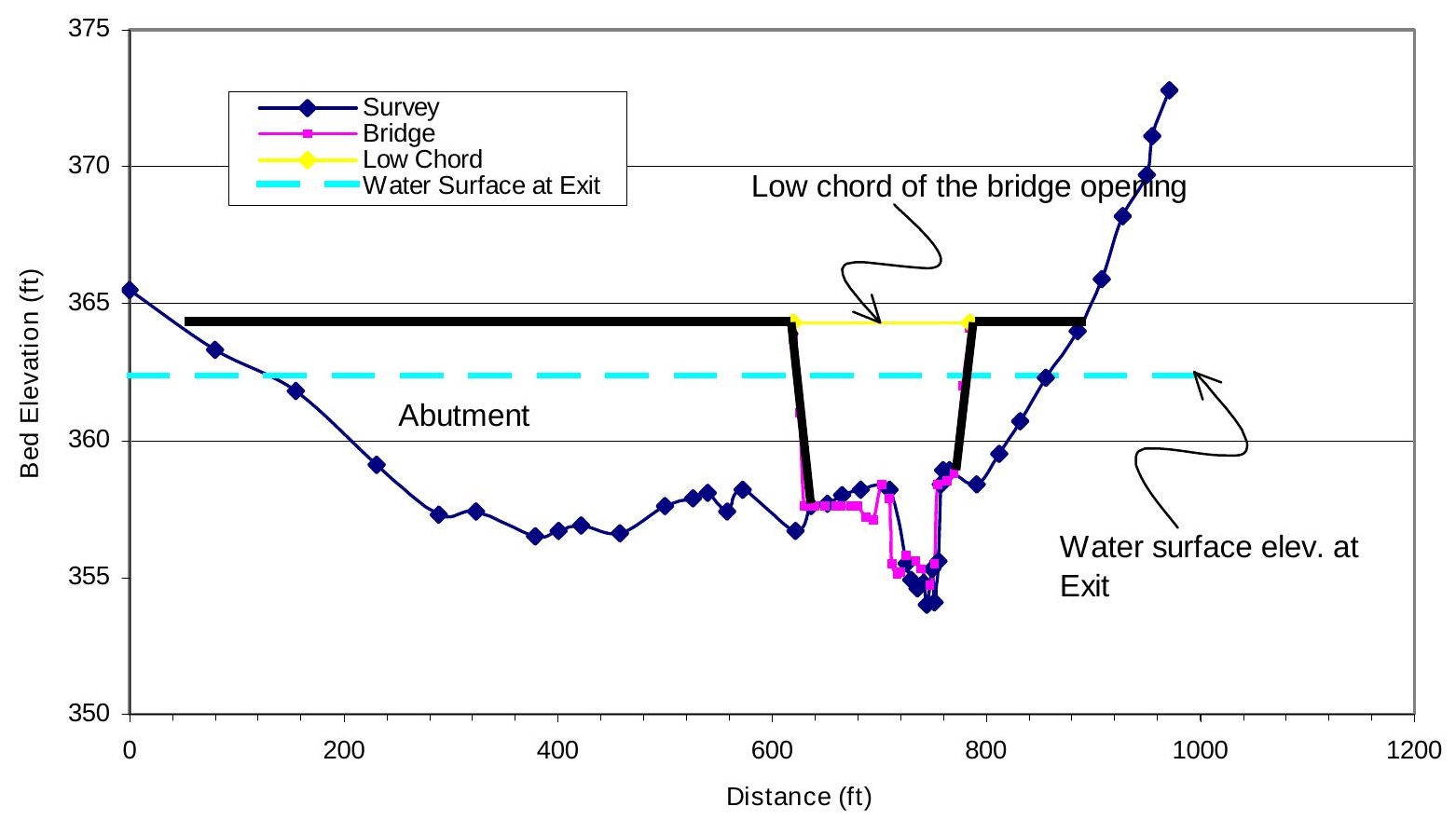

Figure 1. Geometry Plot for Case Indian.S32 

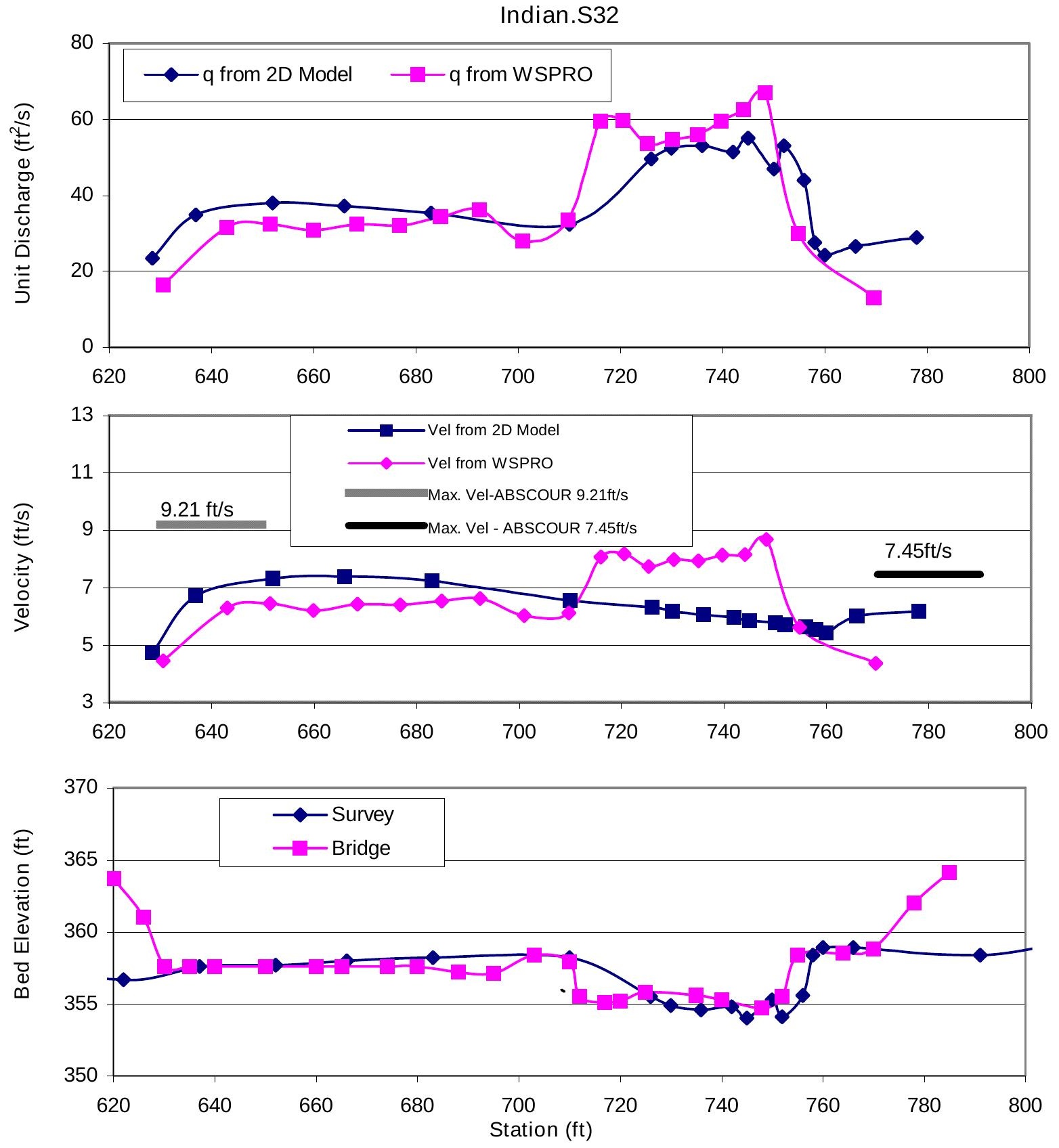

Figure 2. Velocity and Discharge Profile for Case Indian.S32 


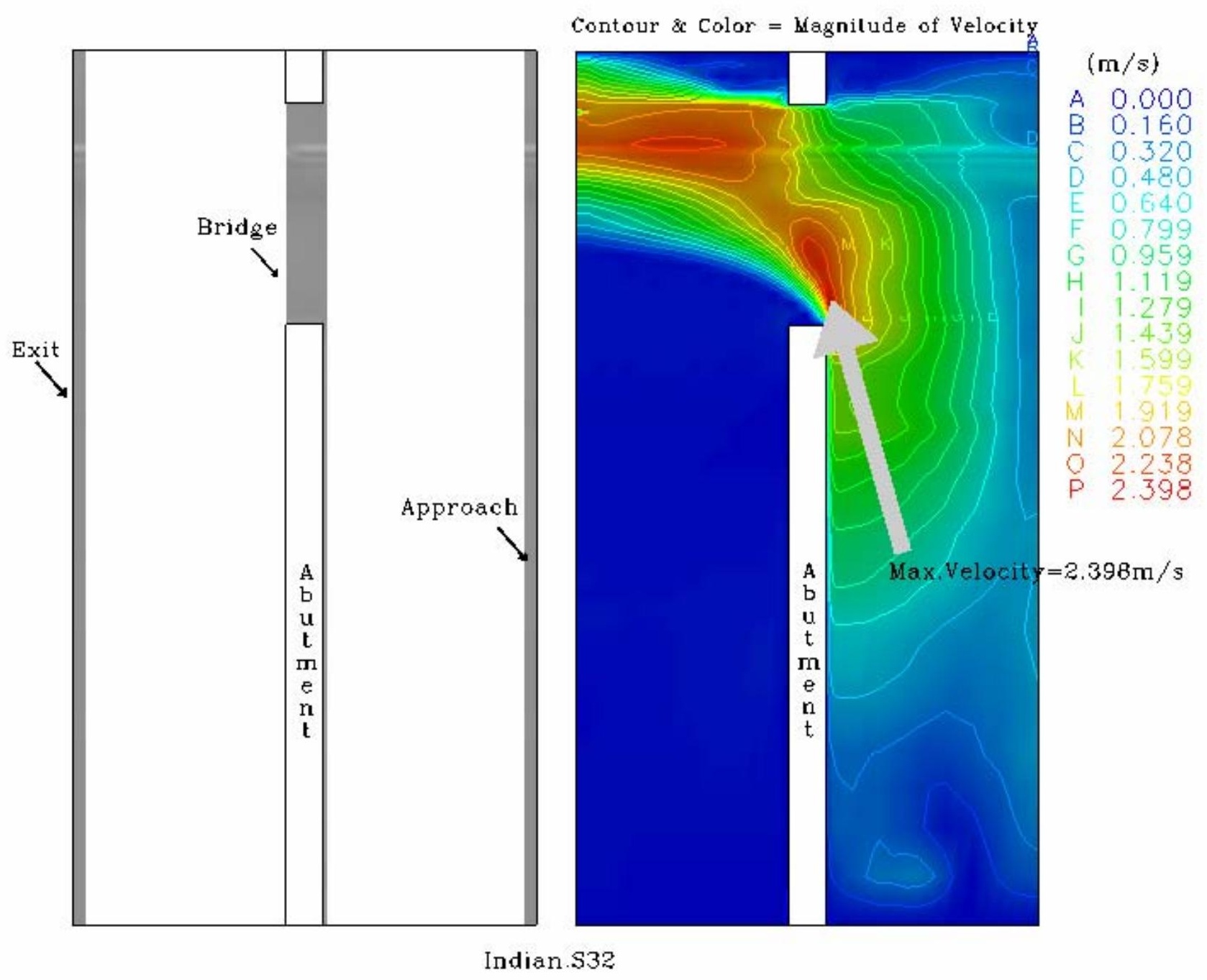

Figure 3. The Plain View of the Case Indian.S32 


\section{B. Cannons Creek@, S299, Newberry County}

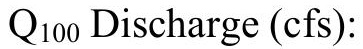

5,130

Elevation Slope:

W.S. Elevation at the Exit (ft):

0.0015

Manning's $\mathrm{n}$ at the Approach Section:

Simulated Channel Length (ft):

96.53

Span at Bridge Section $(\mathrm{ft})$ :

Cannons.S229

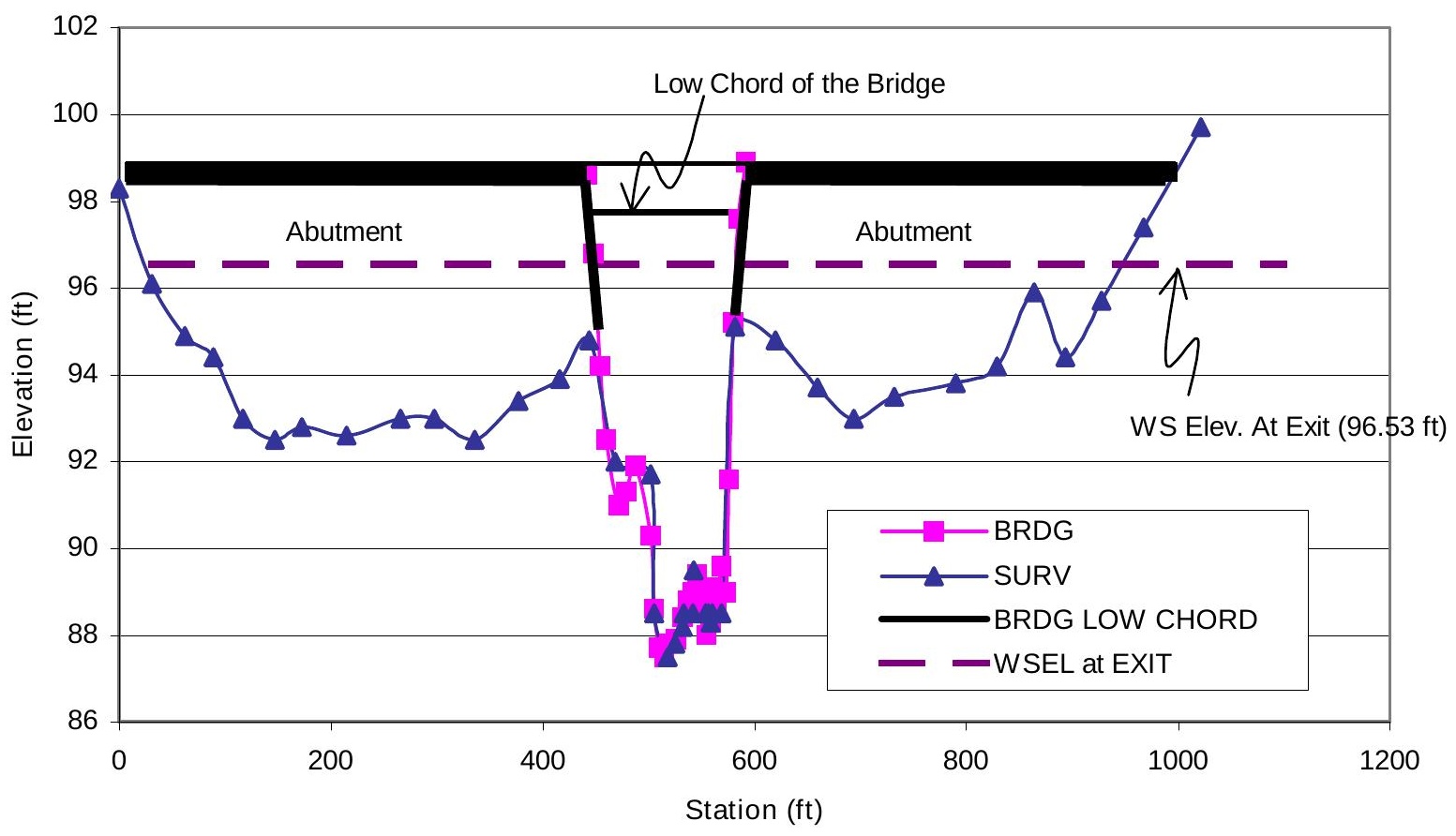

Figure 4. Geometry Plot of Bridge Section for Case Cannons.S229 
Cannons.S229
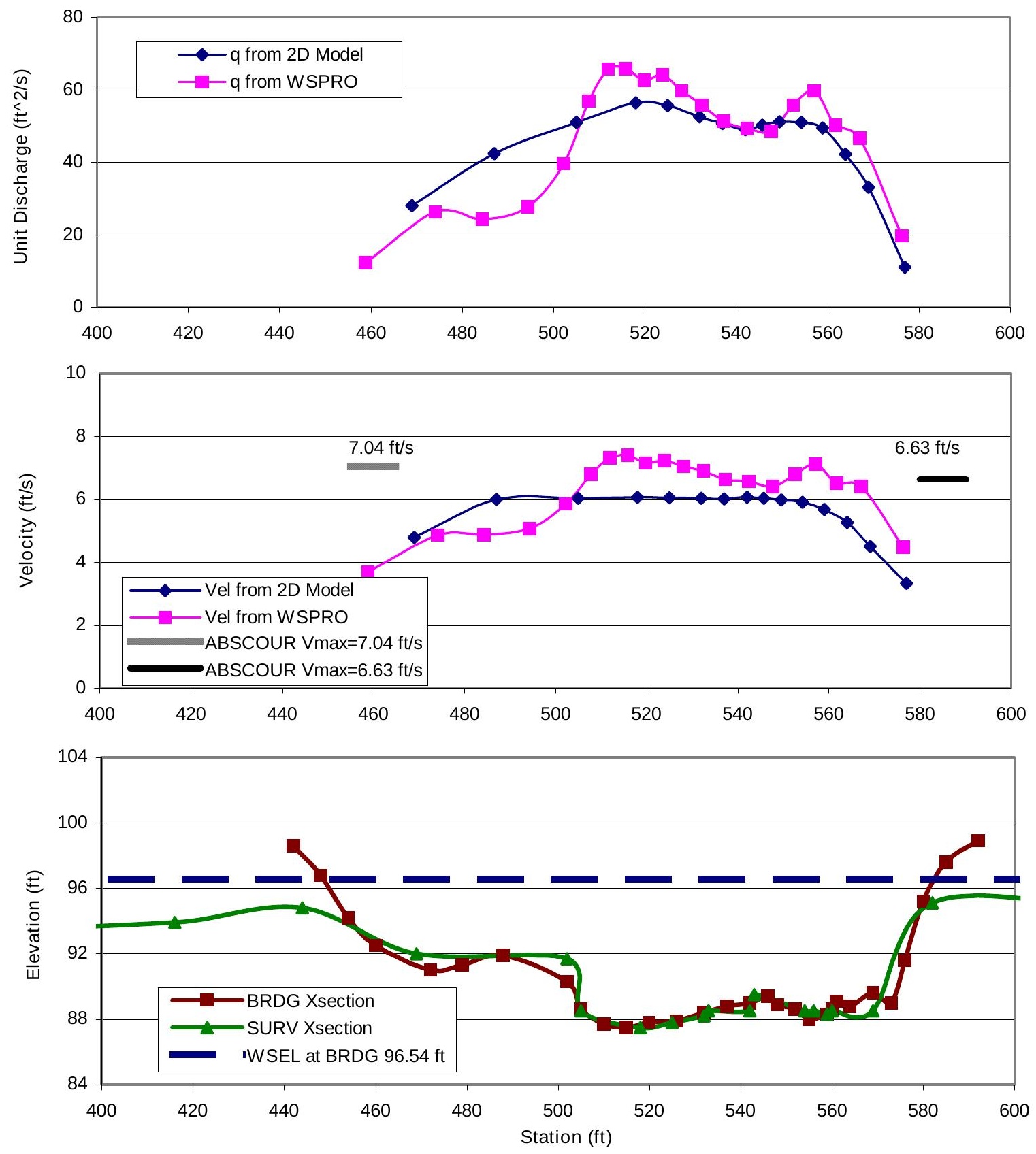

Figure 5. Velocity and Discharge Profile for Case Cannons.S229 


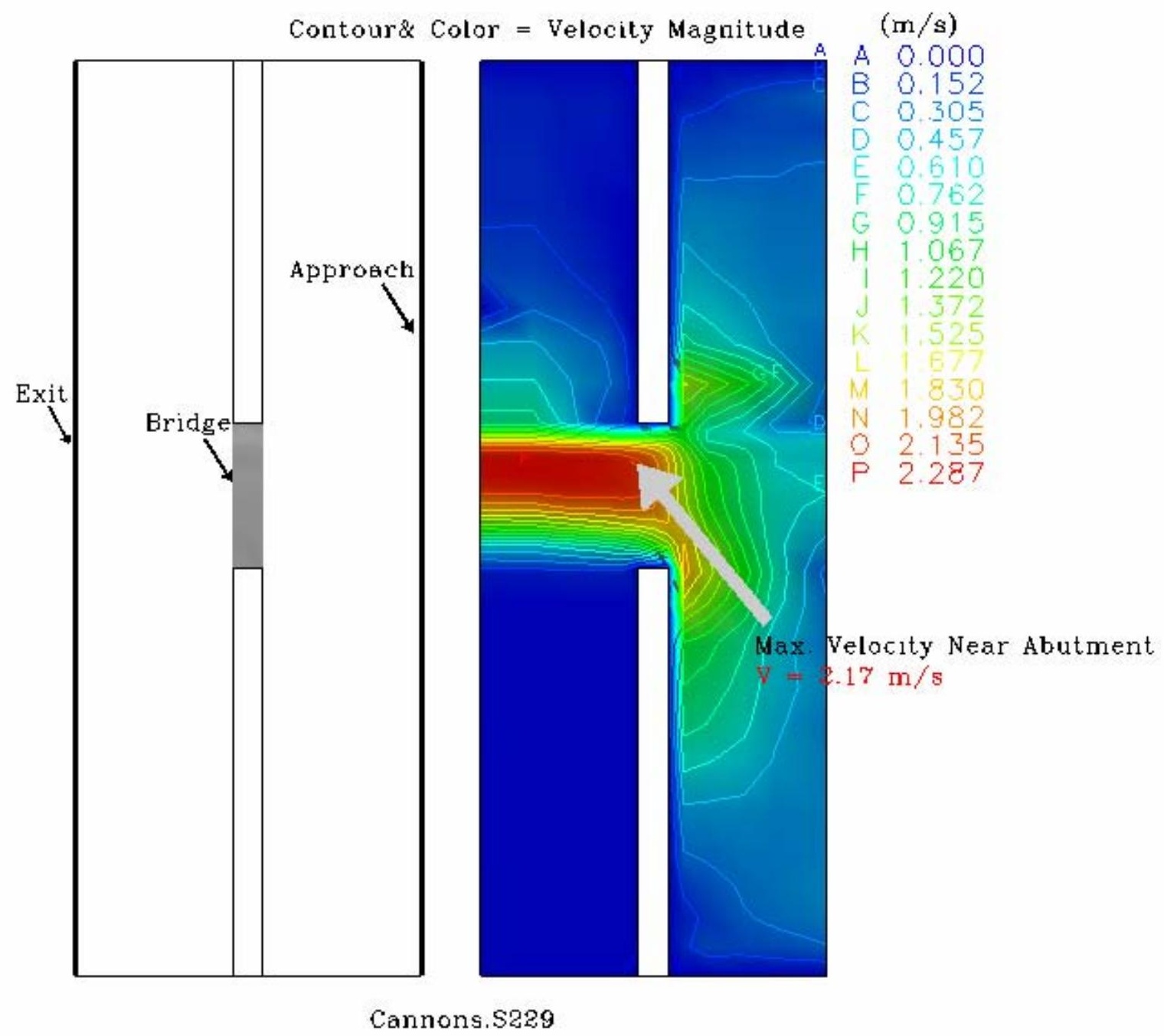

Figure 6. The Plain View of the Case Cannons.S229 
Case C. Turkey Creek@, SC9, Chester County

Q100 Discharge (cfs):

17,400

Elevation Slope:

W.S. Elevation at the Exit (ft):

0.0007

Manning's $n$ at the Approach Section:

Simulated Channel Length ( $\mathrm{ft}$ ):

90.22

Span at Bridge Section (ft):

$0.14 / 0.045 / 0.10(\mathrm{LOB} / \mathrm{MC} / \mathrm{ROB})$

666

316

Turkey Creek @ Rt9

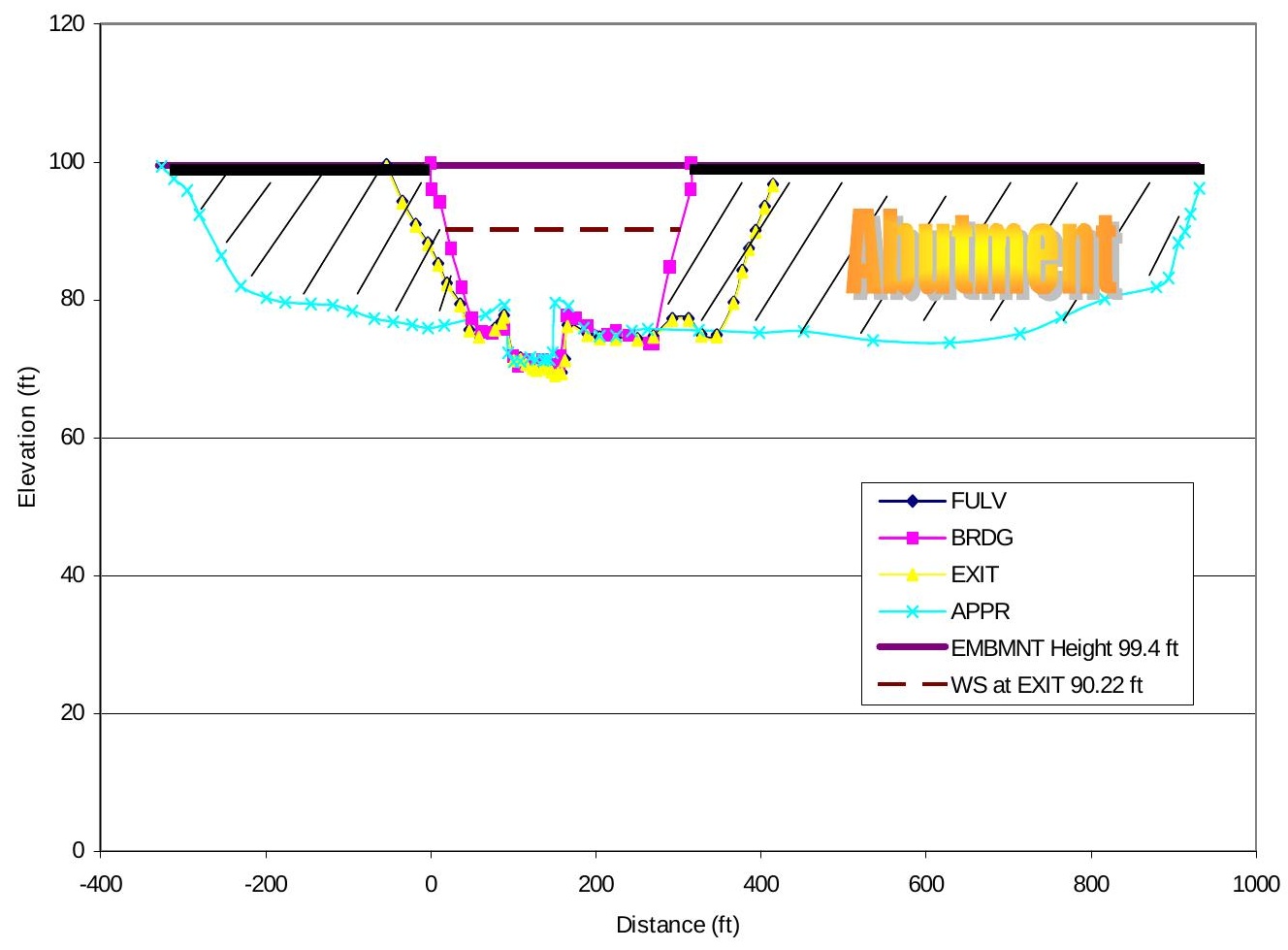

Figure 7. Geometry Plot of Bridge Section for Case Turkey@ SC9 

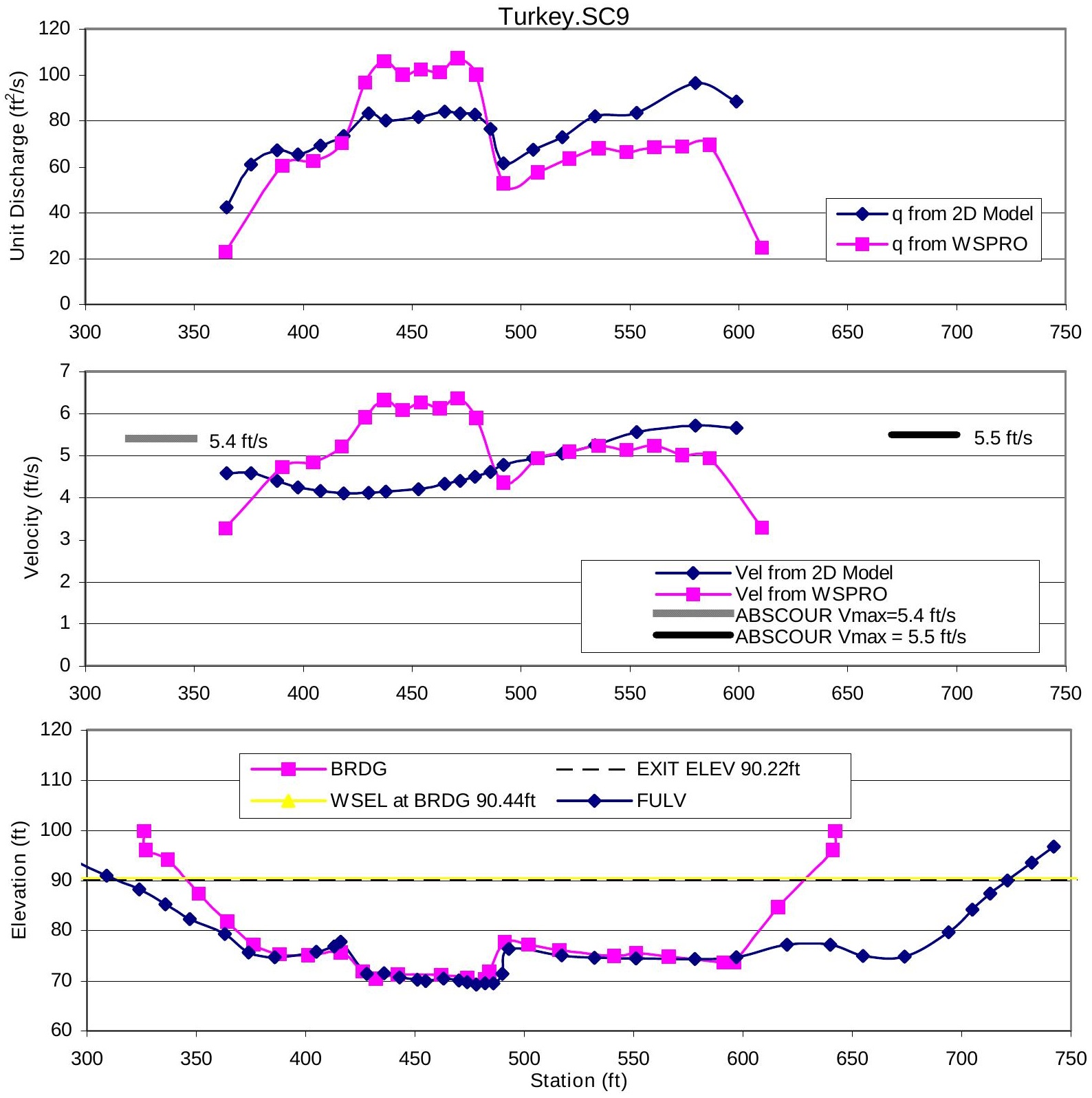

Figure 8. Velocity and Discharge Profile for Case Turkey Creek@ SC 9 
2-D Numerical Simulation

Turkey Creek@SC 9

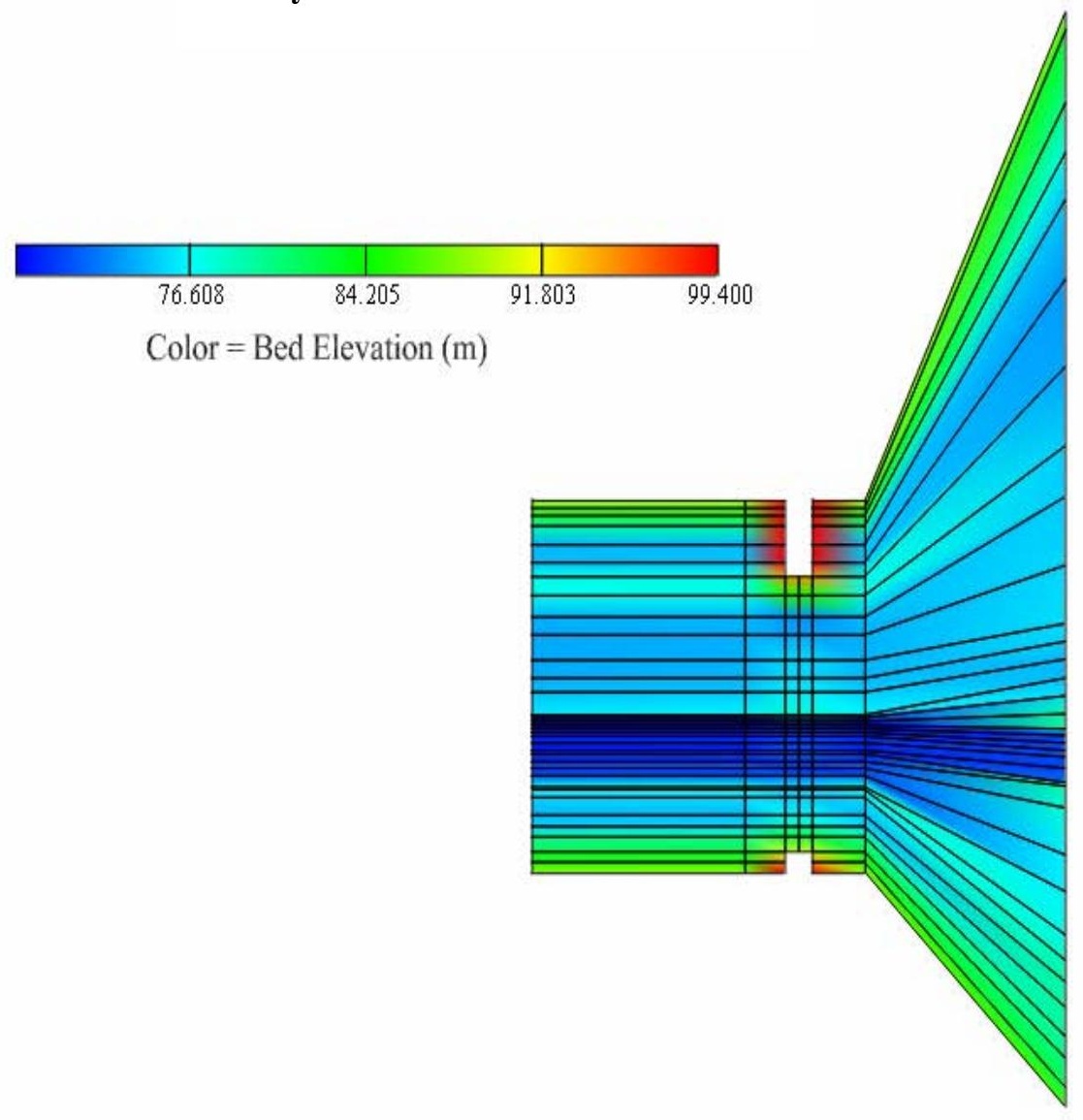

Figure 9. Two-Dimensional Mesh for Case Turkey Creek@ SC9

Constructed Using Cross Sections from WSPRO (Shearman, 1990) 
2-D Velocity Vector Plot for Case Turkey.SC9 Color $=$ Velocity Magnitude $(\mathrm{m} / \mathrm{s})$ $=1.77 \mathrm{~m} / \mathrm{s}$

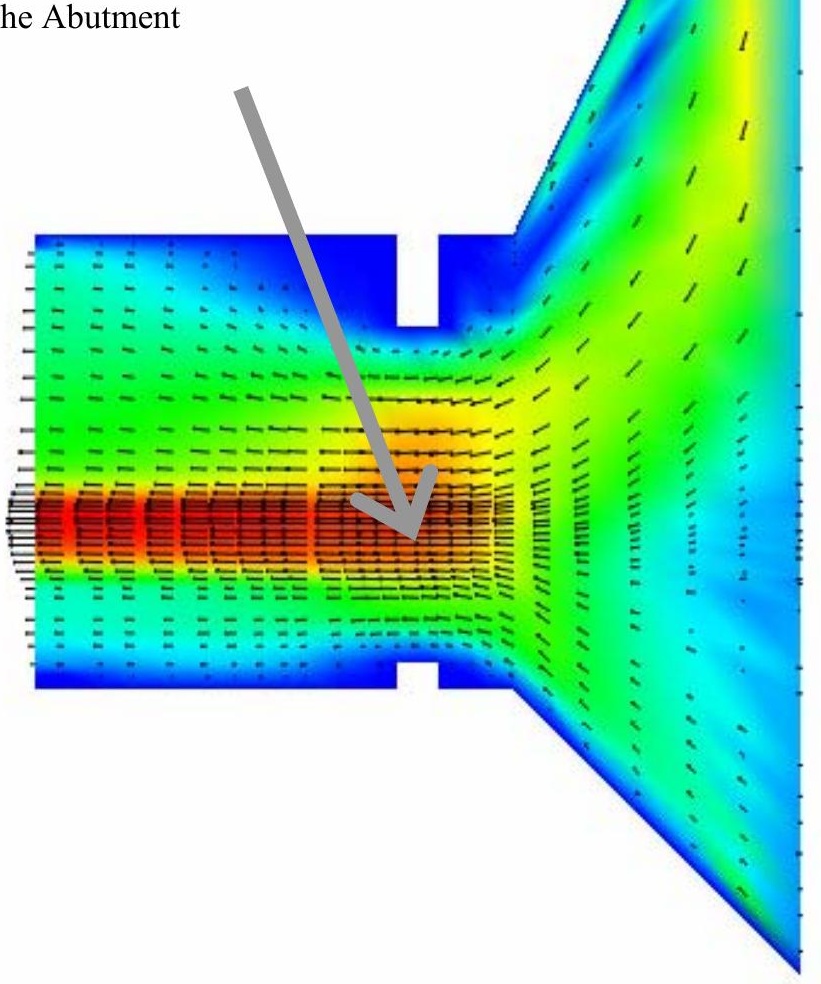

$(\mathrm{m} / \mathrm{s})$

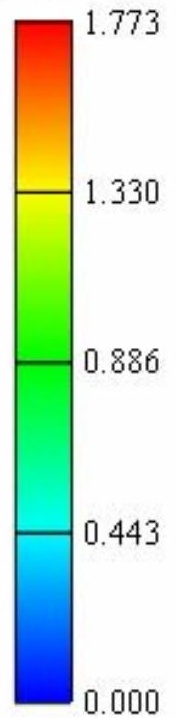

Figure 10. Two-Dimensional Flow Field for Case Turkey Creek @ SC9 Simulated by Using CCHE2D-GUI (Zhang, 2005) 
Case D. Enoree River@, SC146, Spartanburg County

$\mathrm{Q}_{100}$ Discharge (cfs):

10,000

Elevation Slope:

W.S. Elevation at the Exit (ft):

0.00148

Manning's $\mathrm{n}$ at the Approach Section:

Simulated Channel Length (ft):

0.22

Span at Bridge Section $(\mathrm{ft})$ :

$0.15 / 0.06 / 0.15$ (LOB/MC/ROB)

617

292

Enoree.SC146

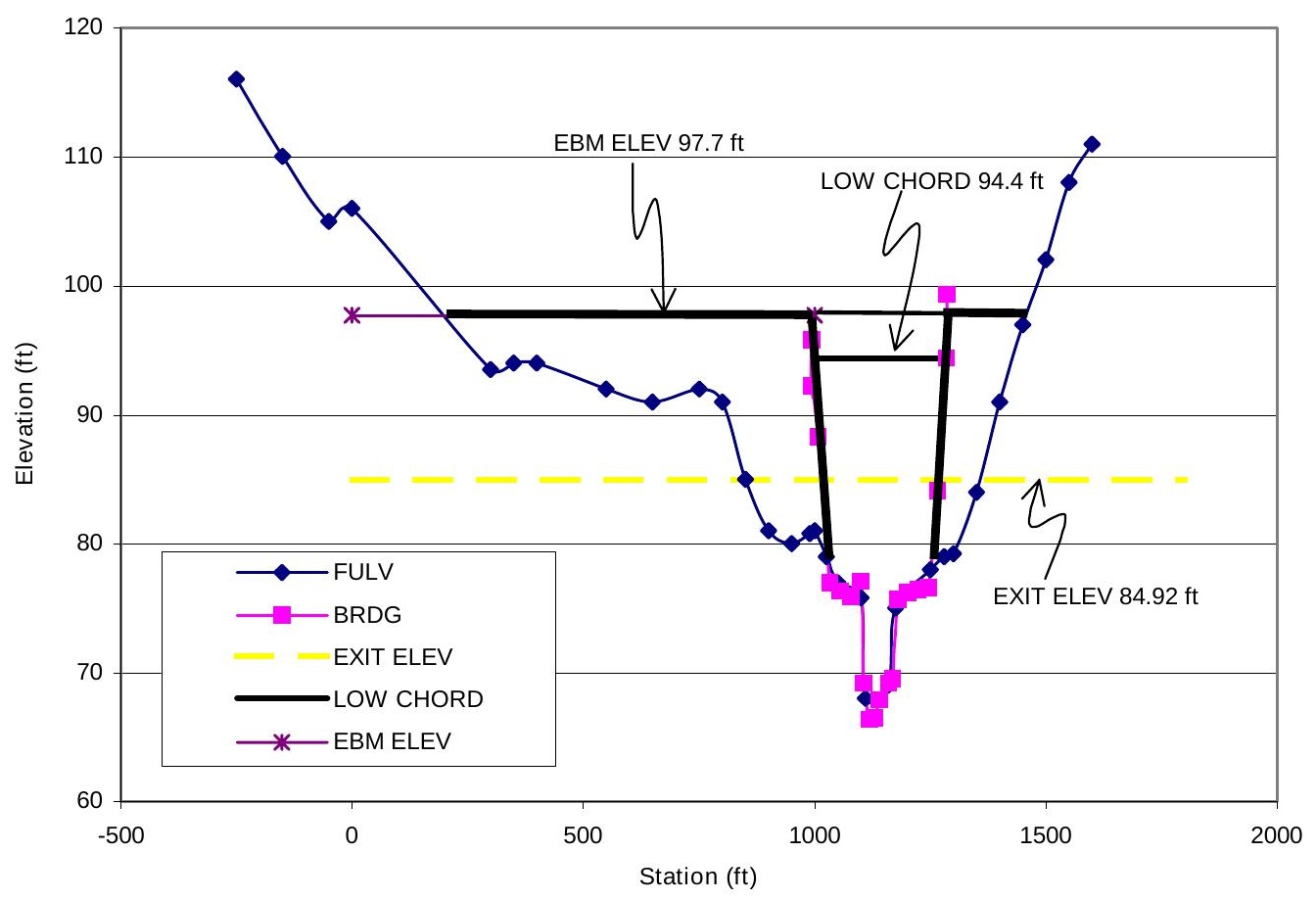

Figure 11. Geometry Plot for Case Enoree.SC146 

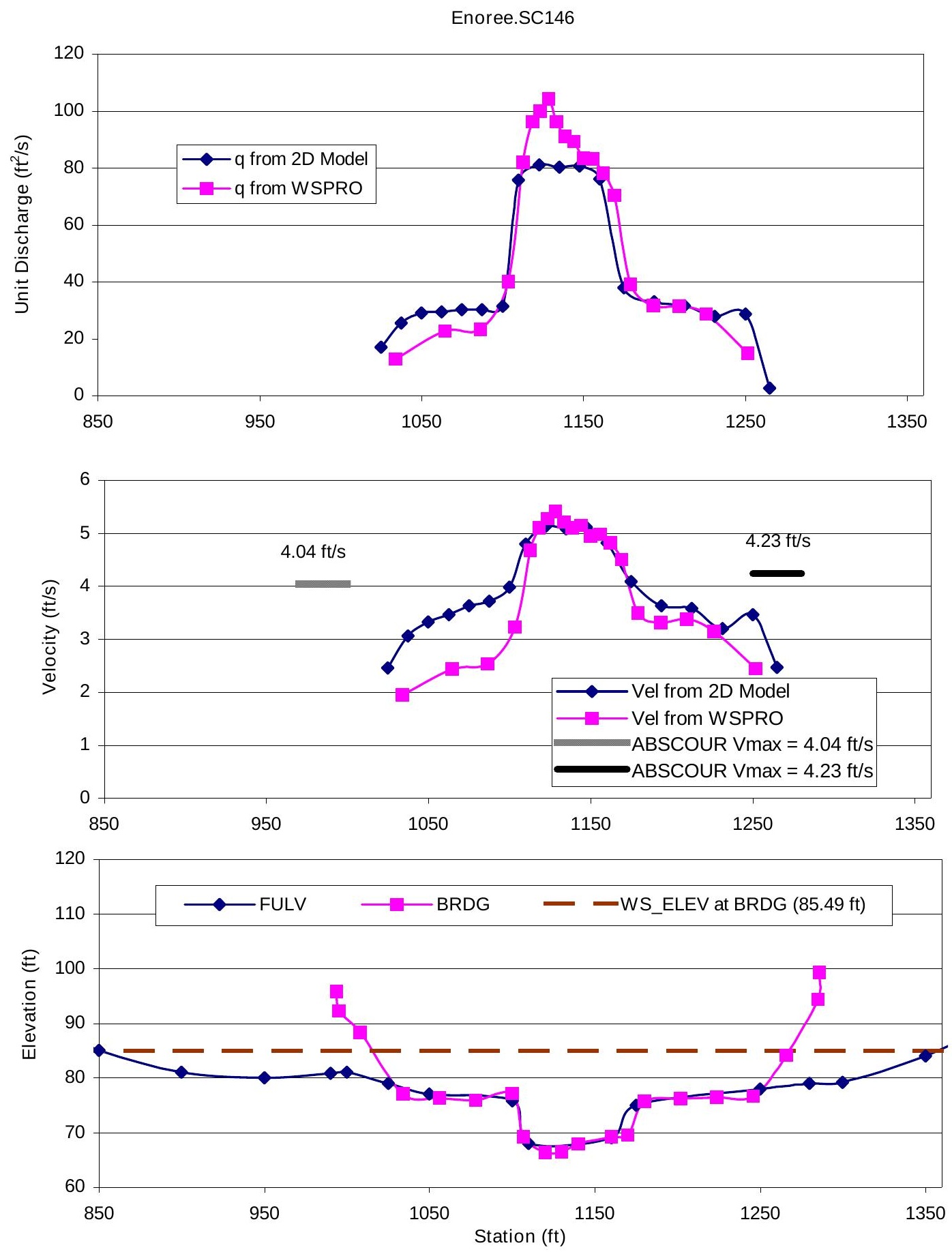

Figure 12. Velocity and Discharge Profile for Case Enoree.SC146 
2-D Numerical Simulation for Case Enoreess146 Contour and Color $=$ Velocity Magnitude $(\mathrm{m} / \mathrm{s})$

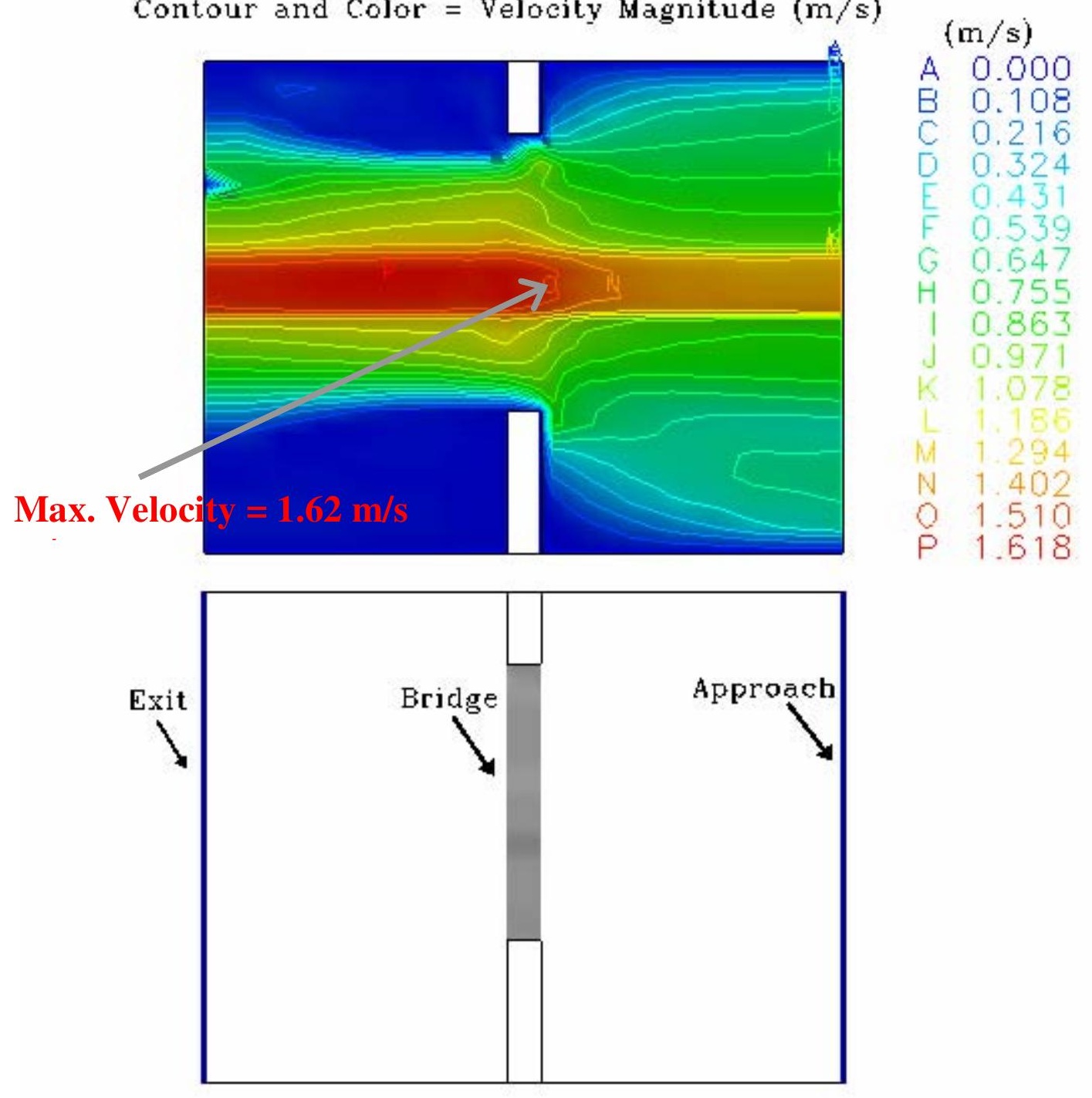

Figure 13. The Plain View of the Case Enoree.SC146 
Case E. Enoree River@, S22, Union County

$\mathrm{Q}_{100}$ Discharge (cfs):

Elevation Slope:

W.S. Elevation at the Exit (ft):

Manning's $n$ at the Approach Section:

Simulated Channel Length $(\mathrm{ft})$ :

Span at Bridge Section (ft):
23,000

0.00133

385.07

0.16/0.04/0.16 (LOB/MC/ROB)

1088

269

Enoree.S22

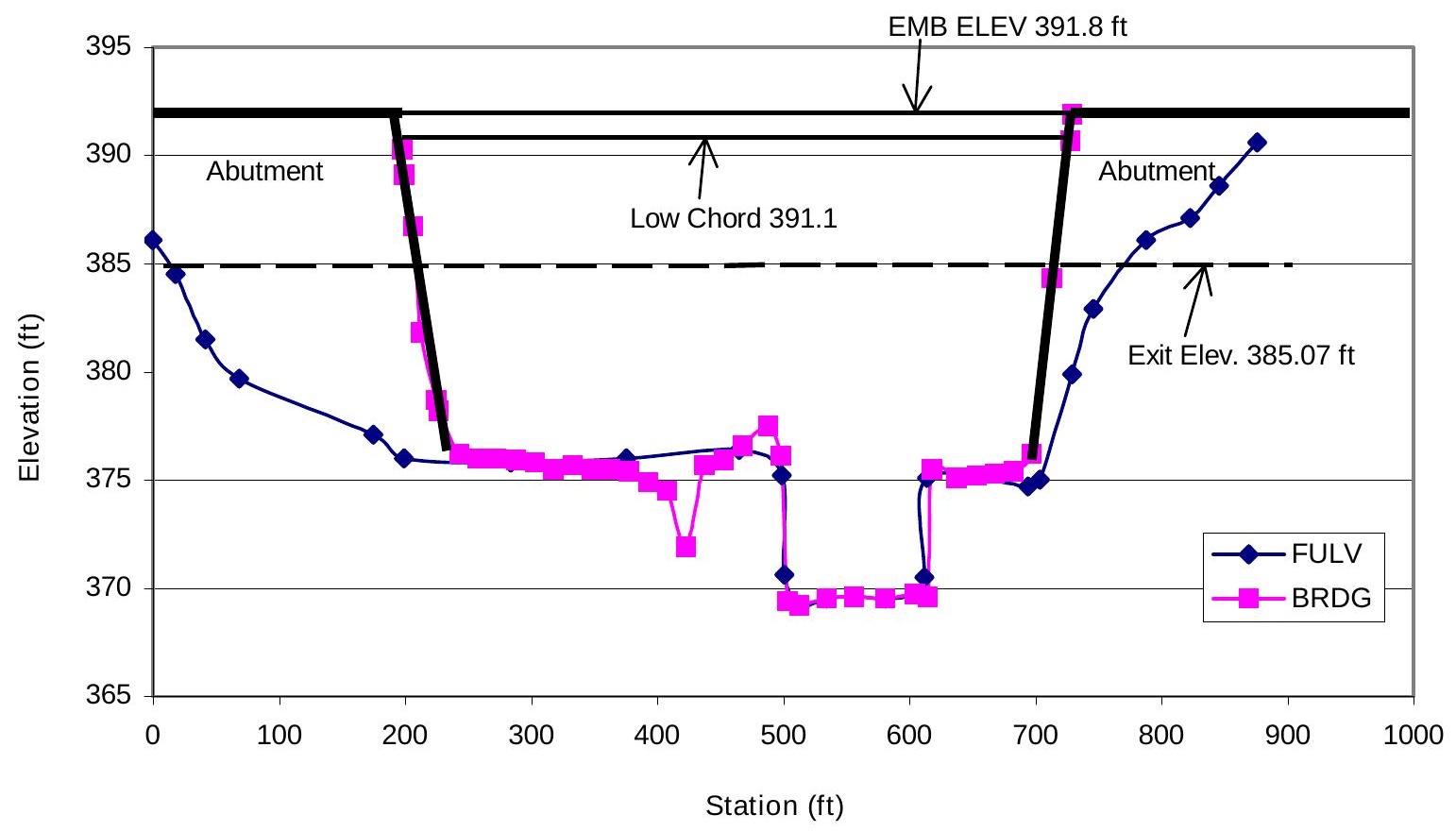

Figure 14. Geometry Plot for Case Enoree.S22 
Enoree.S22
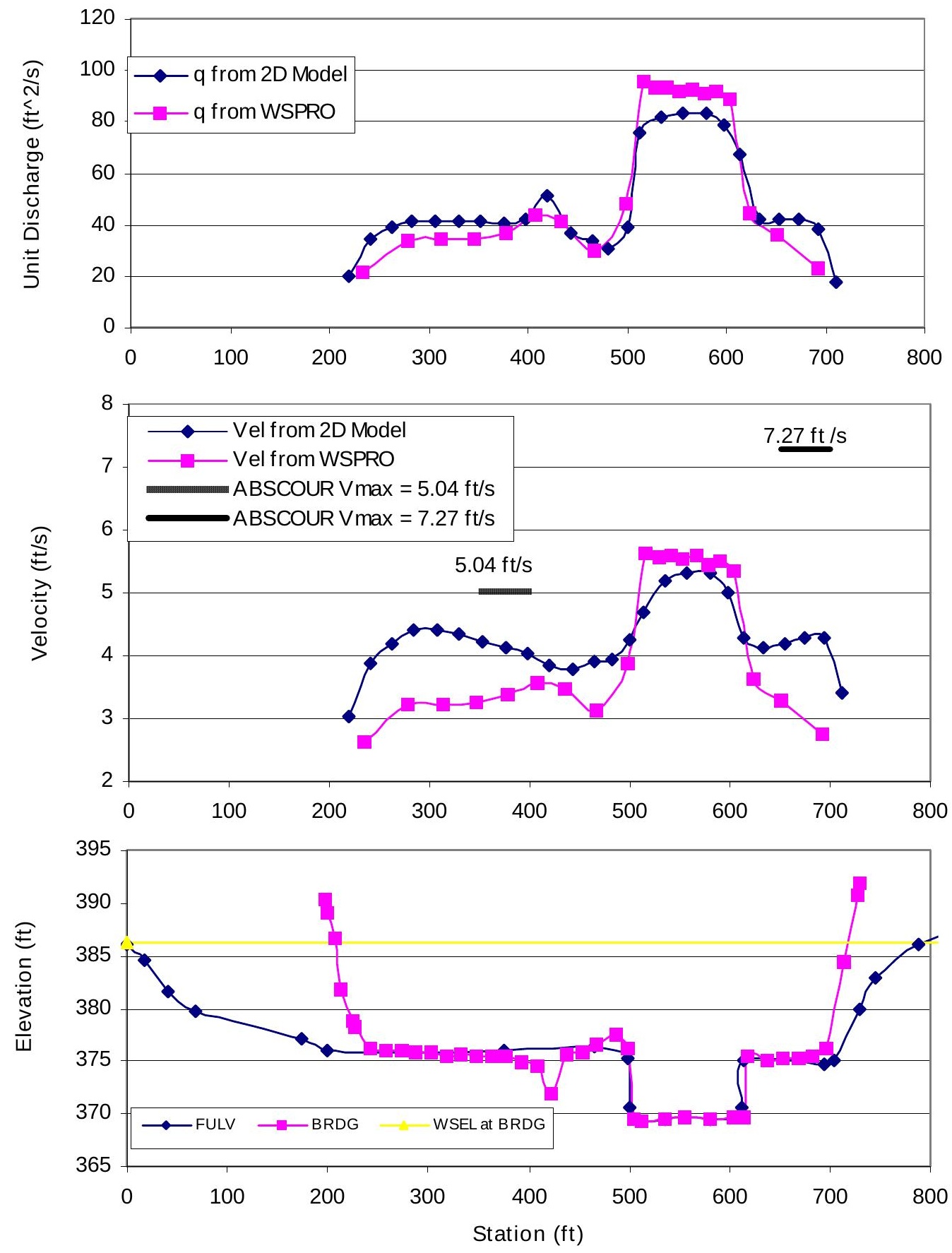

Figure 15. Velocity and Discharge Profile for Case Enoree.S22 
2-D Numerical Simulation for Case Enoree.S22

Contour and Color $=$ Velocity Magnitude $(\mathrm{m} / \mathrm{s})$
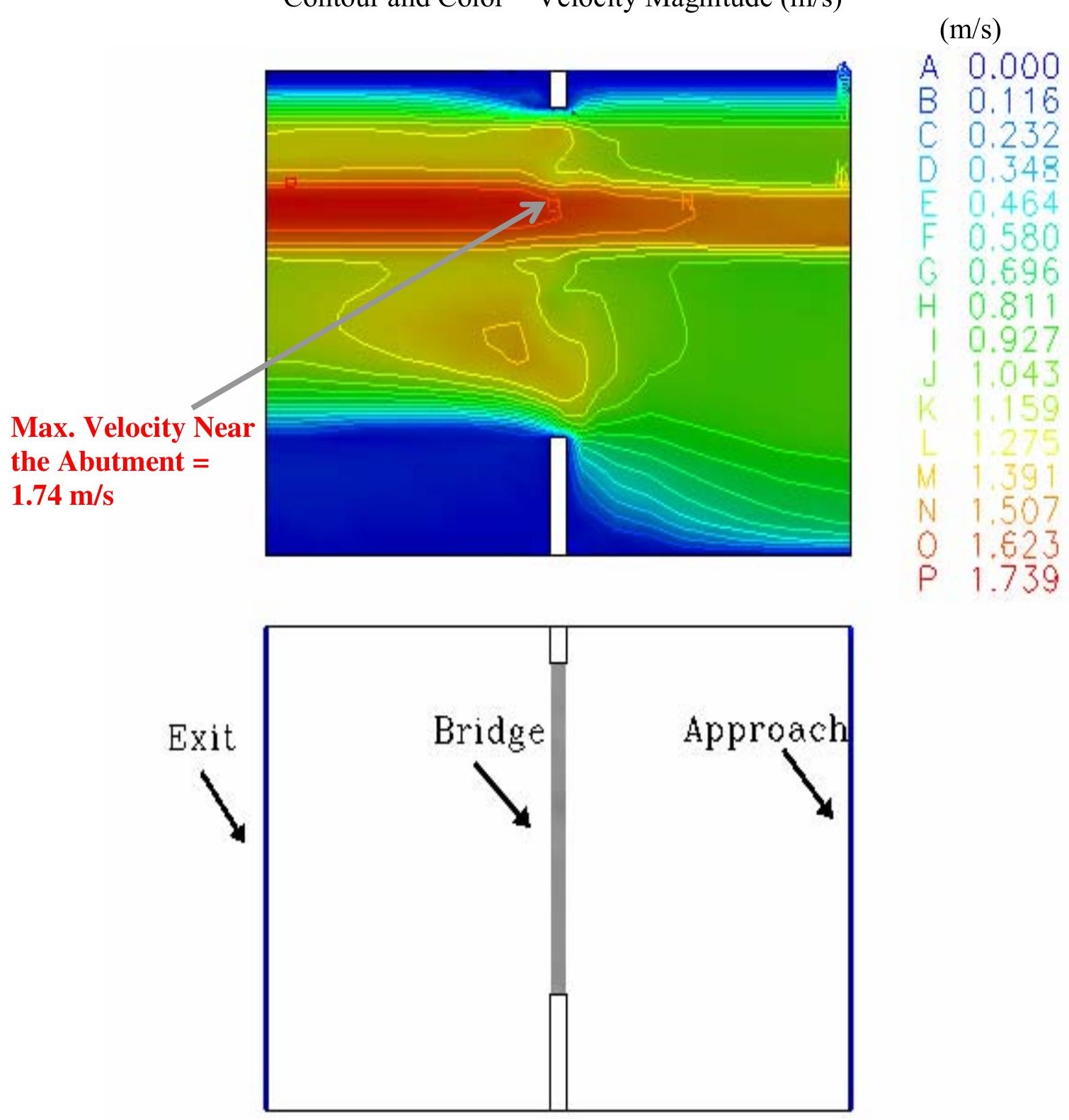

Figure 16. The Plain View of the Case Enoree.S22 
Case F. Enoree River@,S112, Laurens County

$\mathrm{Q}_{100}$ Discharge (cfs):

Elevation Slope:

W.S. Elevation at the Exit (ft):

Manning's $\mathrm{n}$ at the Approach Section:

Simulated Channel Length (ft):

Span at Bridge Section $(\mathrm{ft})$ :
18,500

0.00074

89.59

0.16/0.05/0.16 (LOB/MC/ROB)

635

300

Enoree.S112

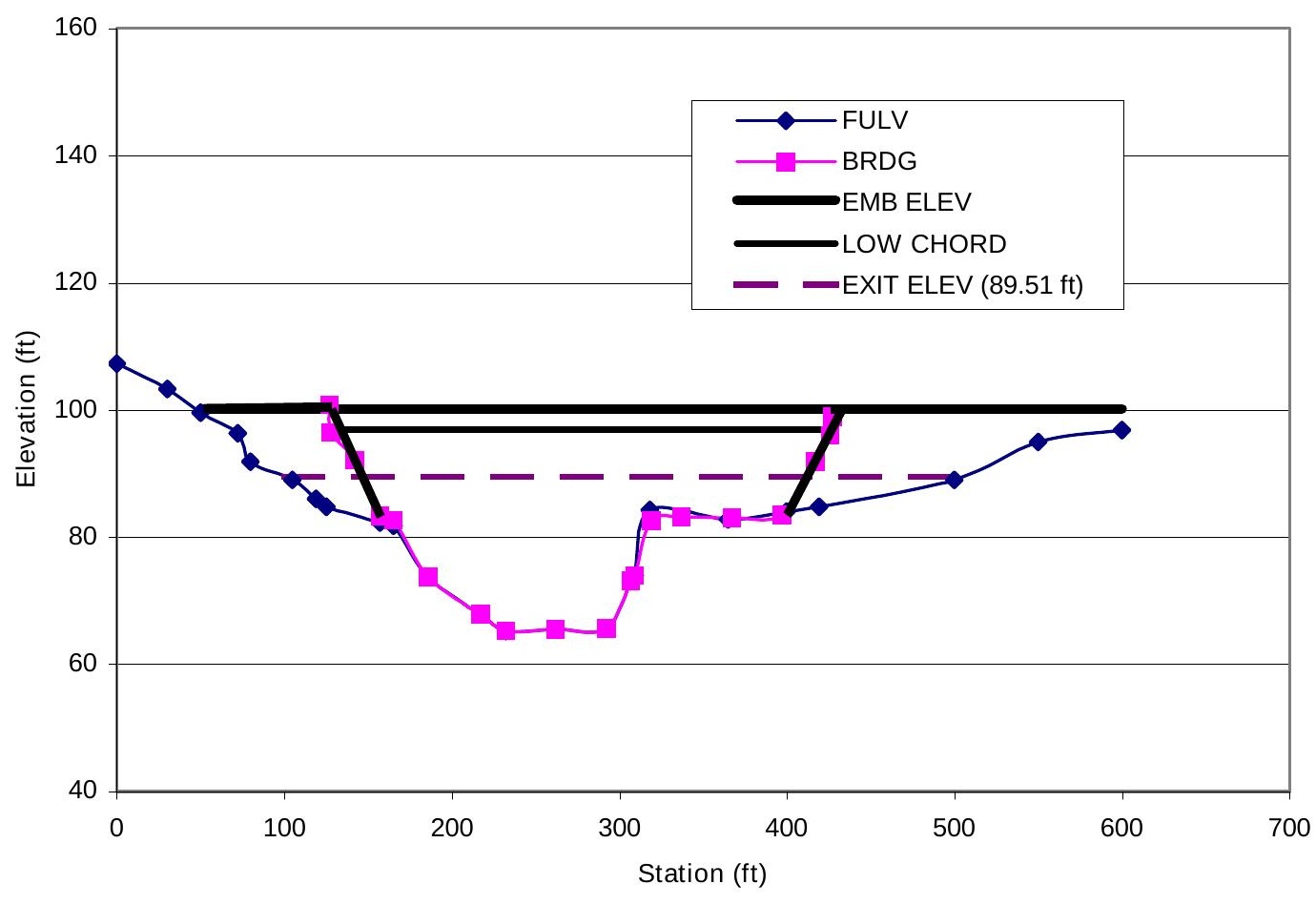

Figure 17. Geometry Plot for Case Enoree.S112 
Enoree.S112
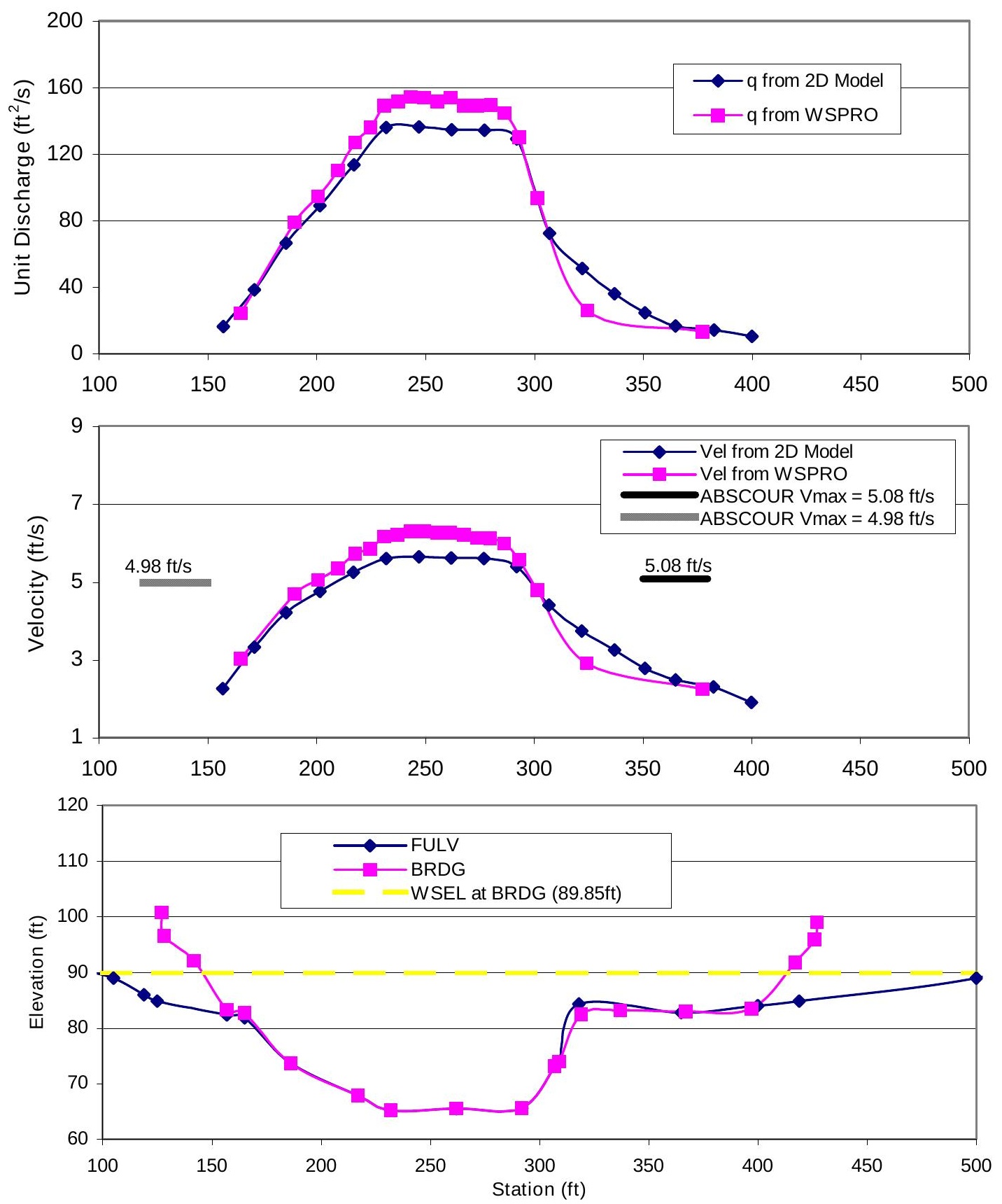

Figure 18. Velocity and Discharge Profile for Case Enoree.S112 
2-D Numerical Simulation for Case Enoree.S112

Contour and Color $=$ Velocity Magnitude $(\mathrm{m} / \mathrm{s})$

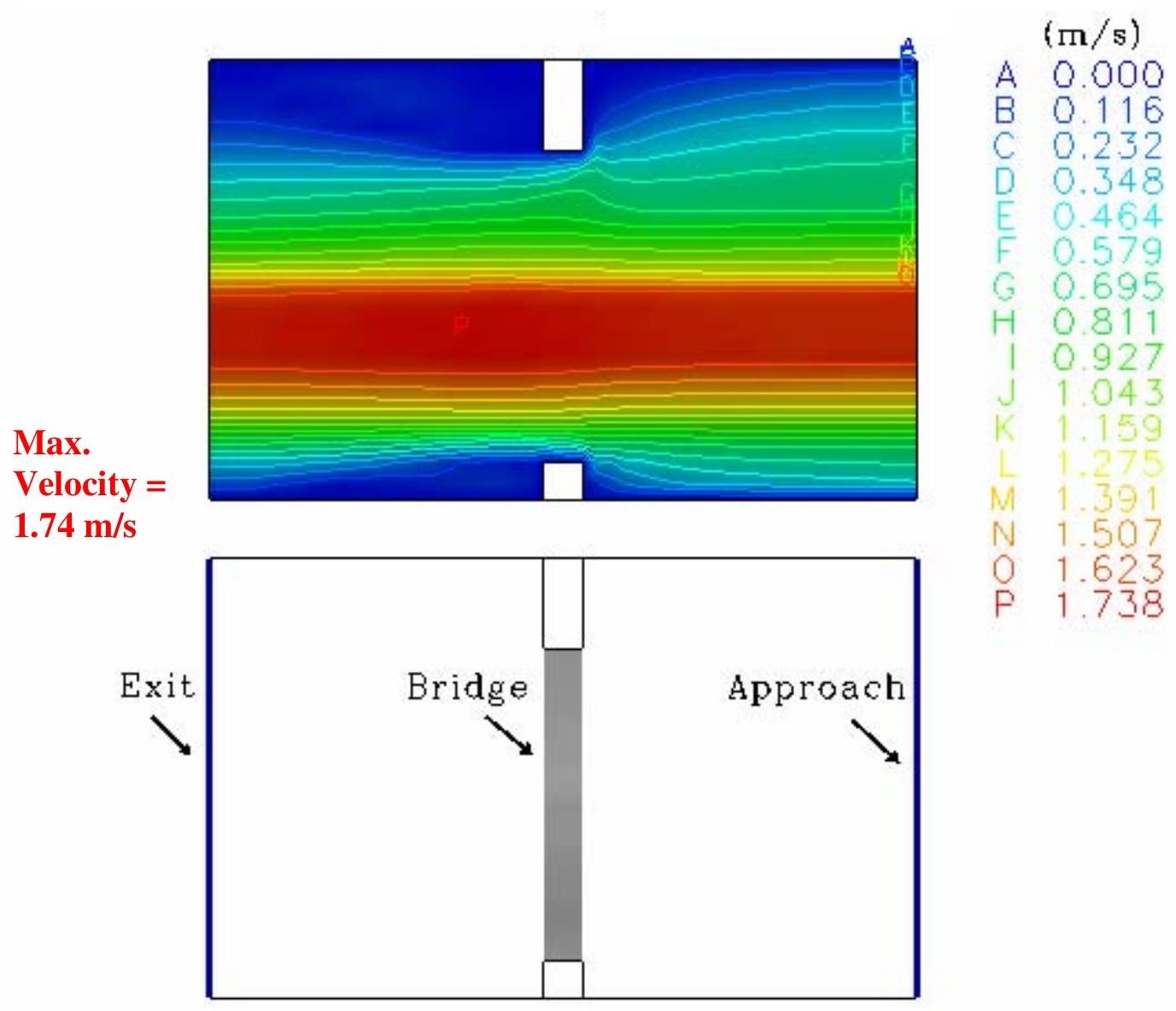

Figure 19. The Plain View of the Case Enoree.S112 
Case G. Reedy River@, S68, Greenville County

$\mathrm{Q}_{100}$ Discharge (cfs):

Elevation Slope:

W.S. Elevation at the Exit (ft):

Manning's $\mathrm{n}$ at the Approach Section:

Simulated Channel Length (ft):

Span at Bridge Section $(\mathrm{ft})$ :
11,900

0.0006

98.01

$0.18 / 0.05 / 0.18(\mathrm{LOB} / \mathrm{MC} / \mathrm{ROB})$

513

330

Reedy.S68

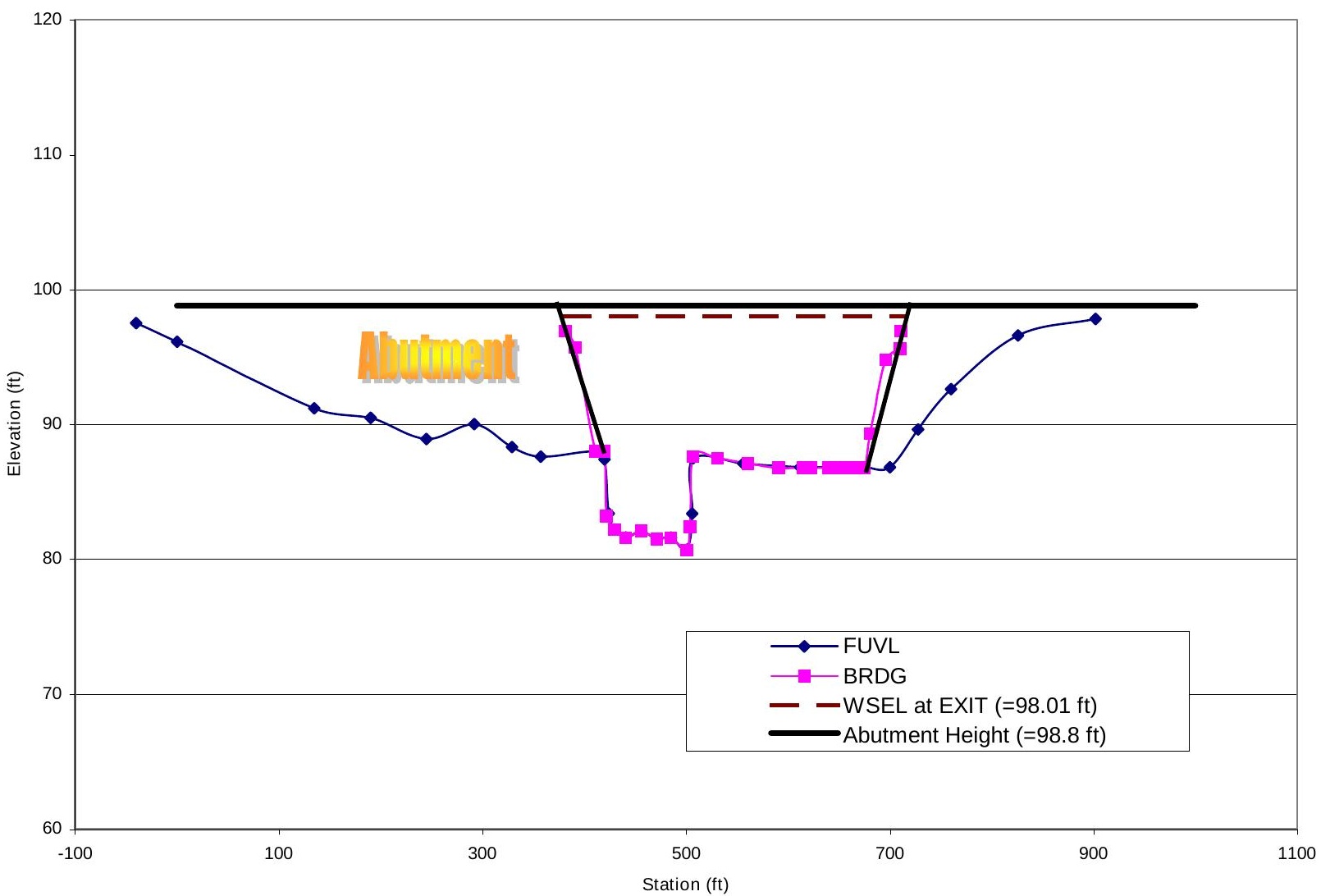

Figure 20. Geometry Plot for Case Reedy.S68 
Reedy.S68
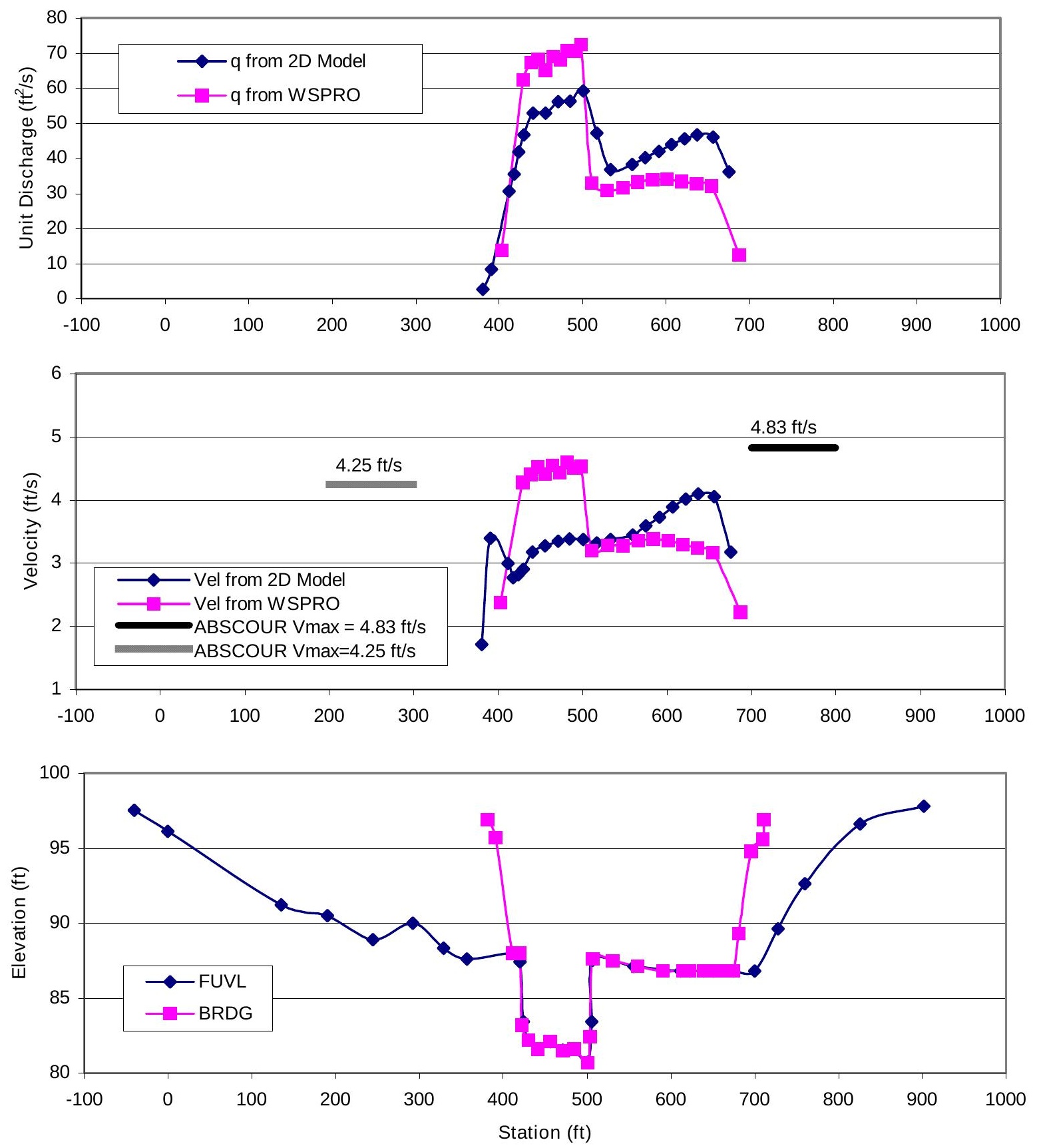

Figure 21. Velocity and Discharge Profile for Case Reedy.S68 
2-D Numerical Simulation for Case Reedy.S68

Contour and Color $=$ Velocity Magnitude $(\mathrm{m} / \mathrm{s})$
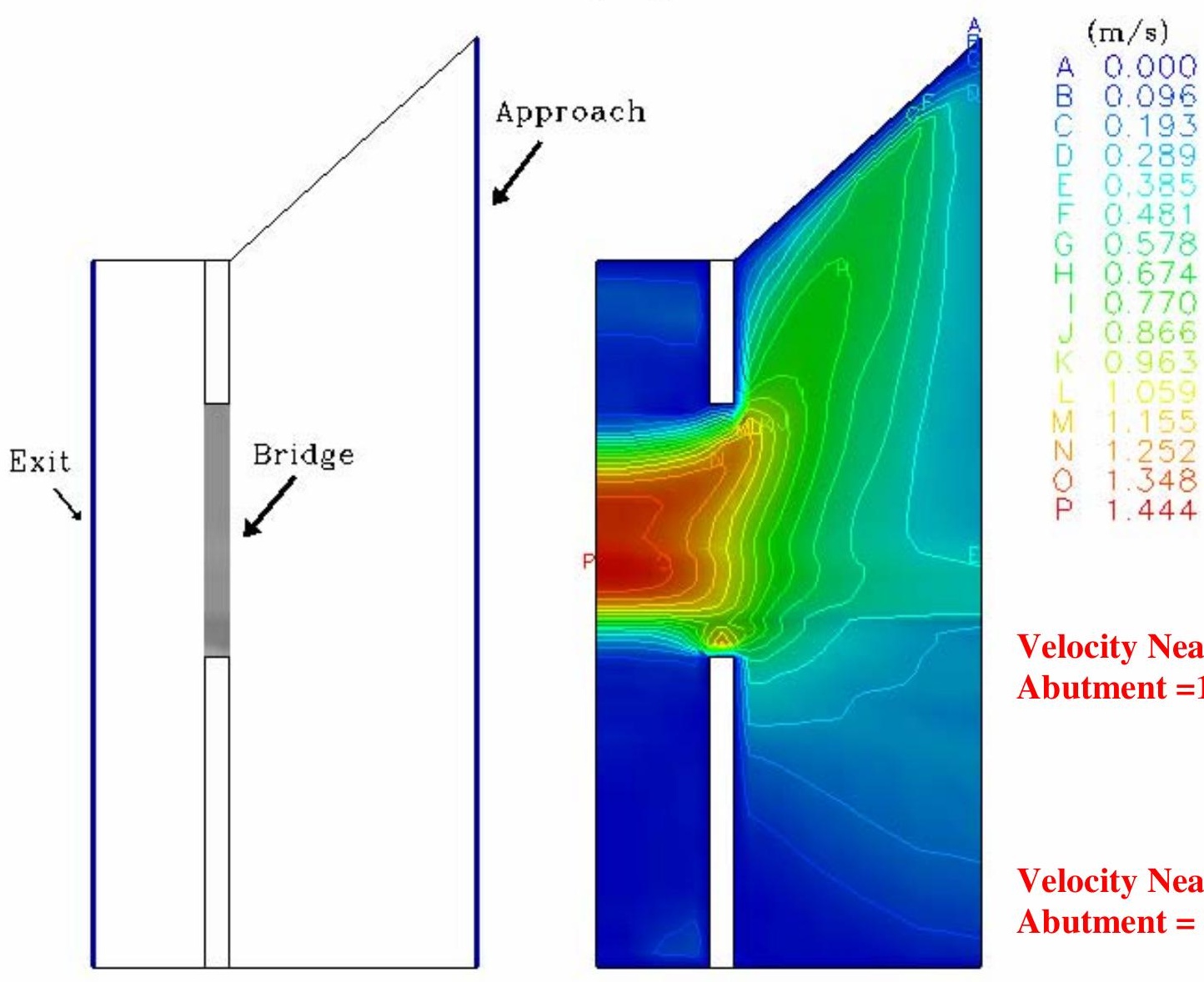

Velocity Near the Right Abutment $=1.15 \mathrm{~m} / \mathrm{s}$

Velocity Near the Left Abutment $=\mathbf{1 . 0} \mathrm{m} / \mathrm{s}$

Figure 22. The Plain View of the Case Reedy.S68 
Case H.ypress Creek@, SC 3, Jasper County

$\mathrm{Q}_{100}$ Discharge (cfs):

Elevation Slope:

W.S. Elevation at the Exit (ft):

Manning's $\mathrm{n}$ at the Approach Section:

Simulated Channel Length ( $\mathrm{ft}$ ):

Span at Bridge Section $(\mathrm{ft})$ :
3,350

0.00064

92.53

$0.16 / 0.16 / 0.16(\mathrm{LOB} / \mathrm{MC} / \mathrm{ROB})$ 1943

210

Cypress Creek @ SC3

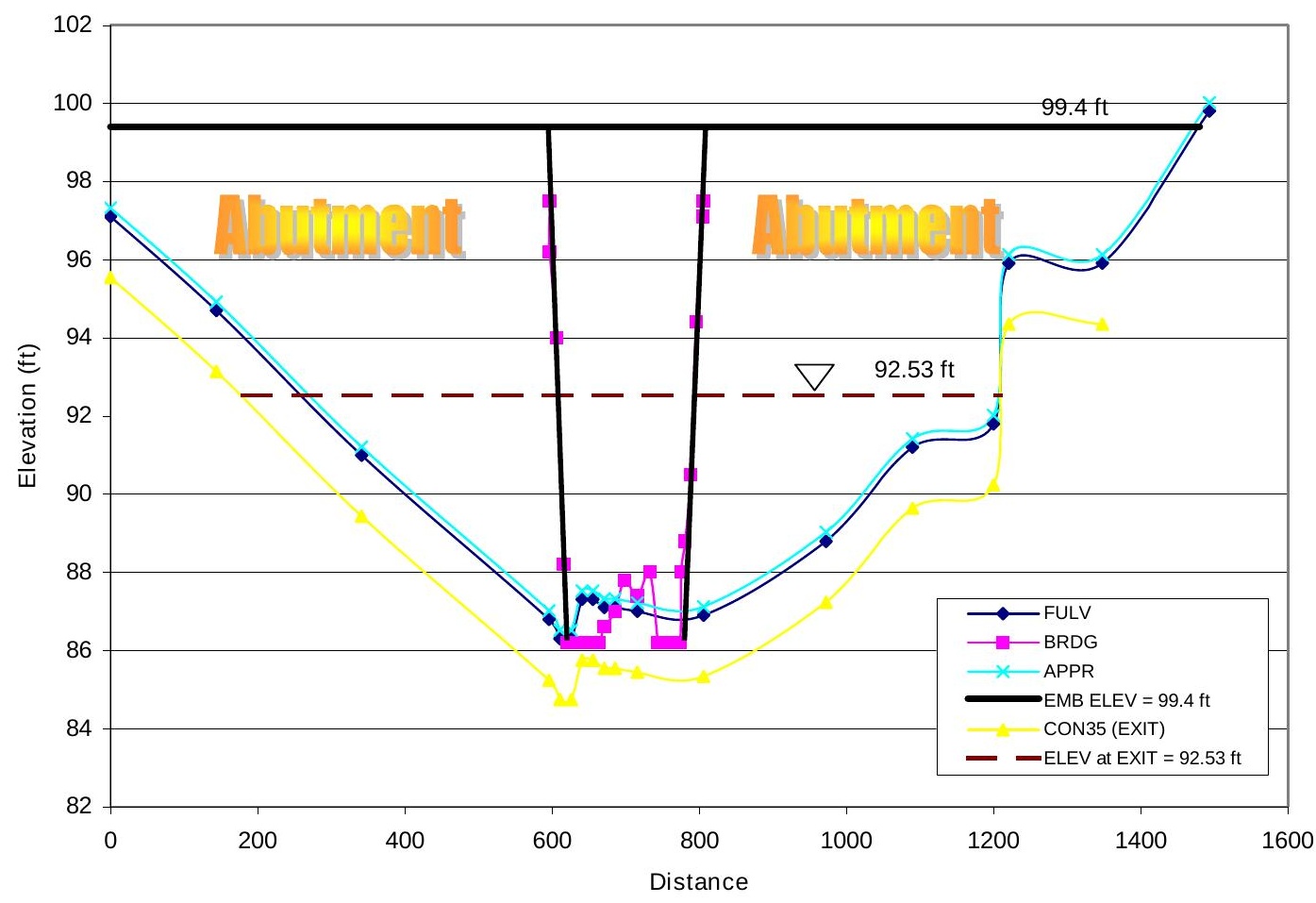

Figure 23. Geometry of Bridge Section of Case Cypress.SC3 
2-D Numerical Simulation for Cypress Creek @ SC 3 Using CCHE2D-GUI

Color $=$ Velocity Magnitude $(\mathrm{m} / \mathrm{s})$

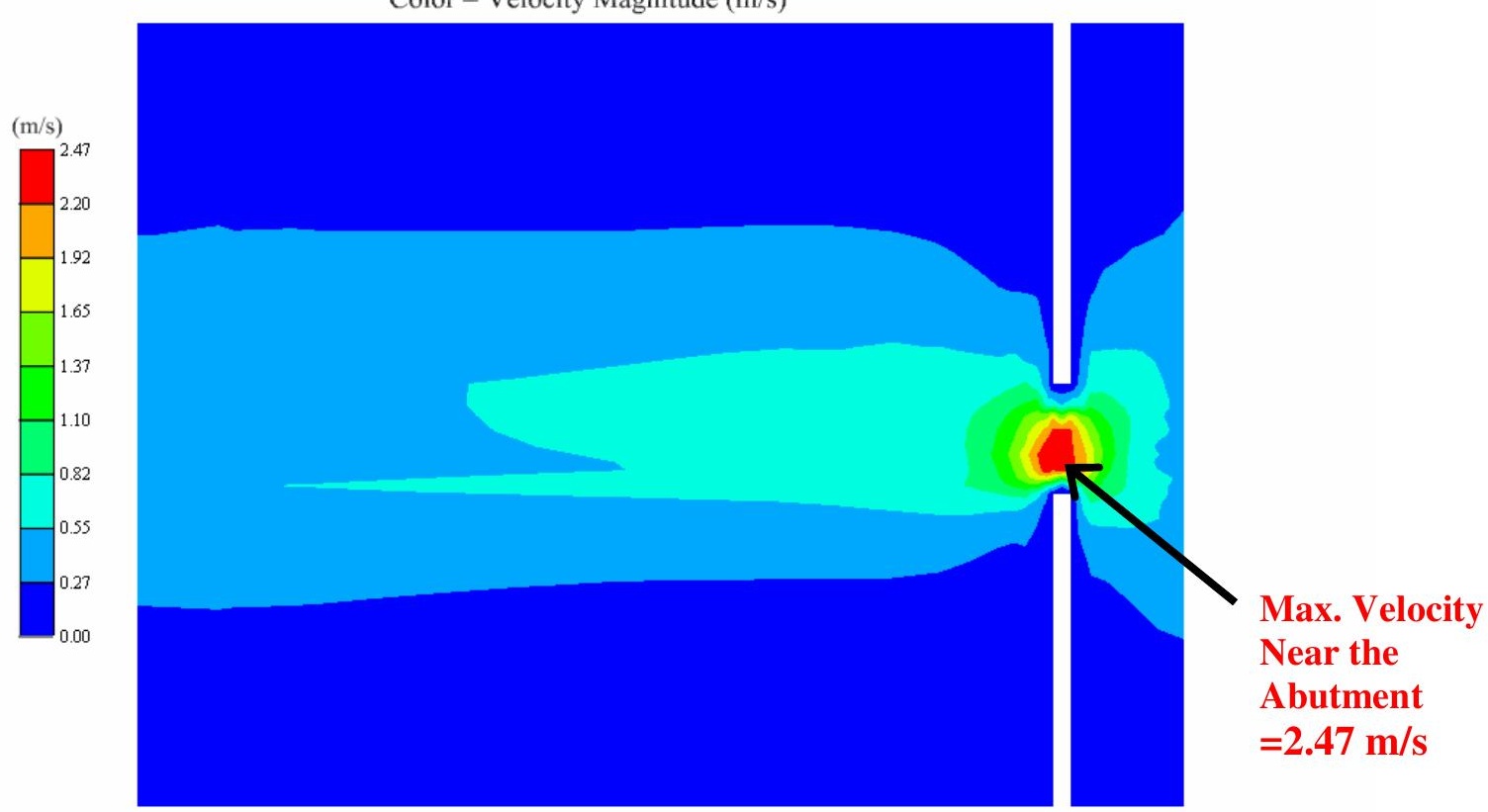

Figure 24. Velocity Magnitude Contour after Real Time Simulation for 3,000 sec. Case Cypress.SC3

2-D Numerical Simulation for Cypress $n$

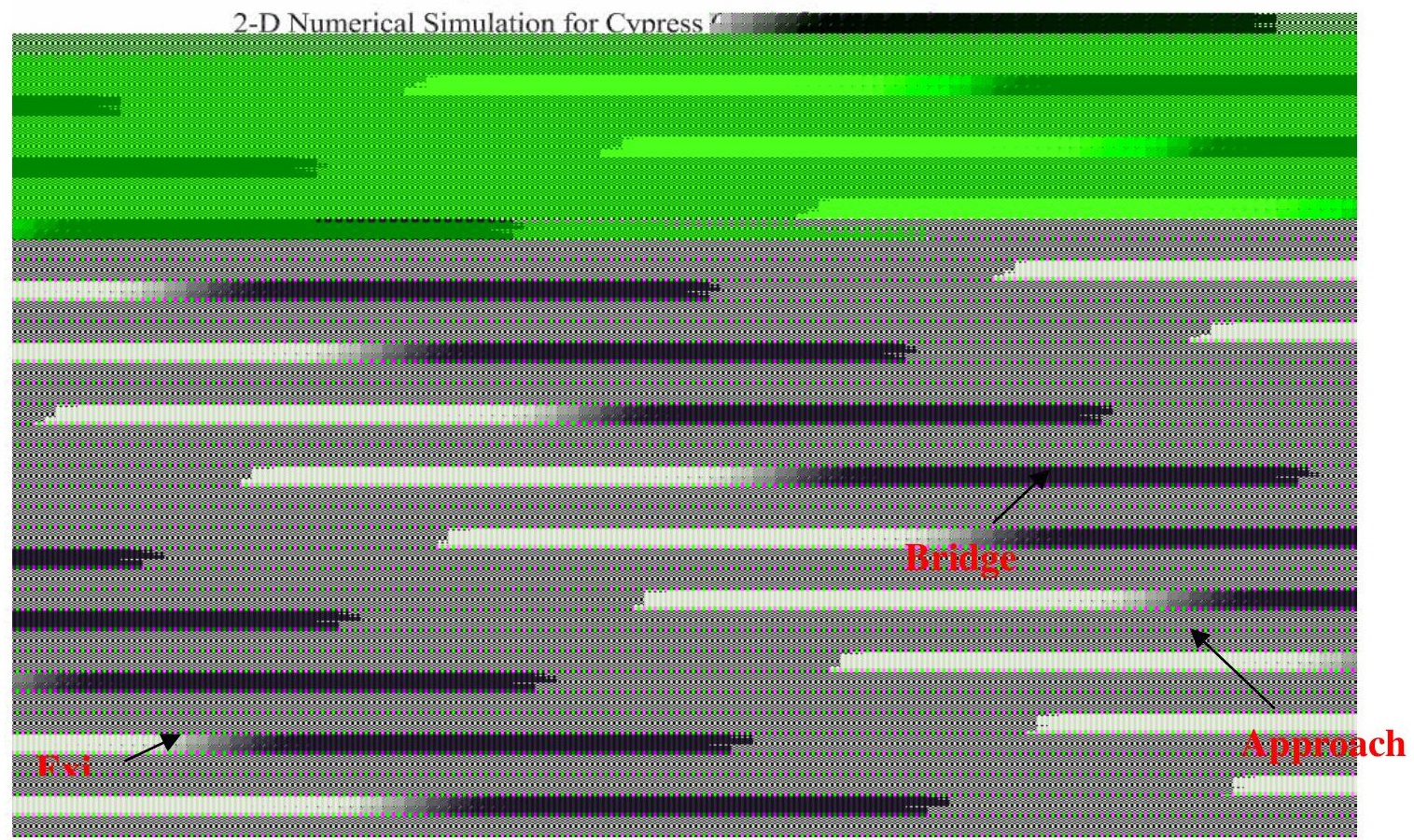

Figure 25. 2-D Mesh Used in Case Cypress.SC3

Color $=$ Water Surface Elevation after 3,000 sec. Simulation 
If the model runs successfully, it will stop when it reaches the number of time steps preset. The final results or the intermediate results can be selected for visualization. Click button "FlowVisualization" to choose the results you want to visual. The results can be plotted to show velocity vectors and velocity magnitude or free-surface elevation using the colored contour lines. Figure 40 shows the vector plots from the result of the 1,000 seconds real time flow simulation.

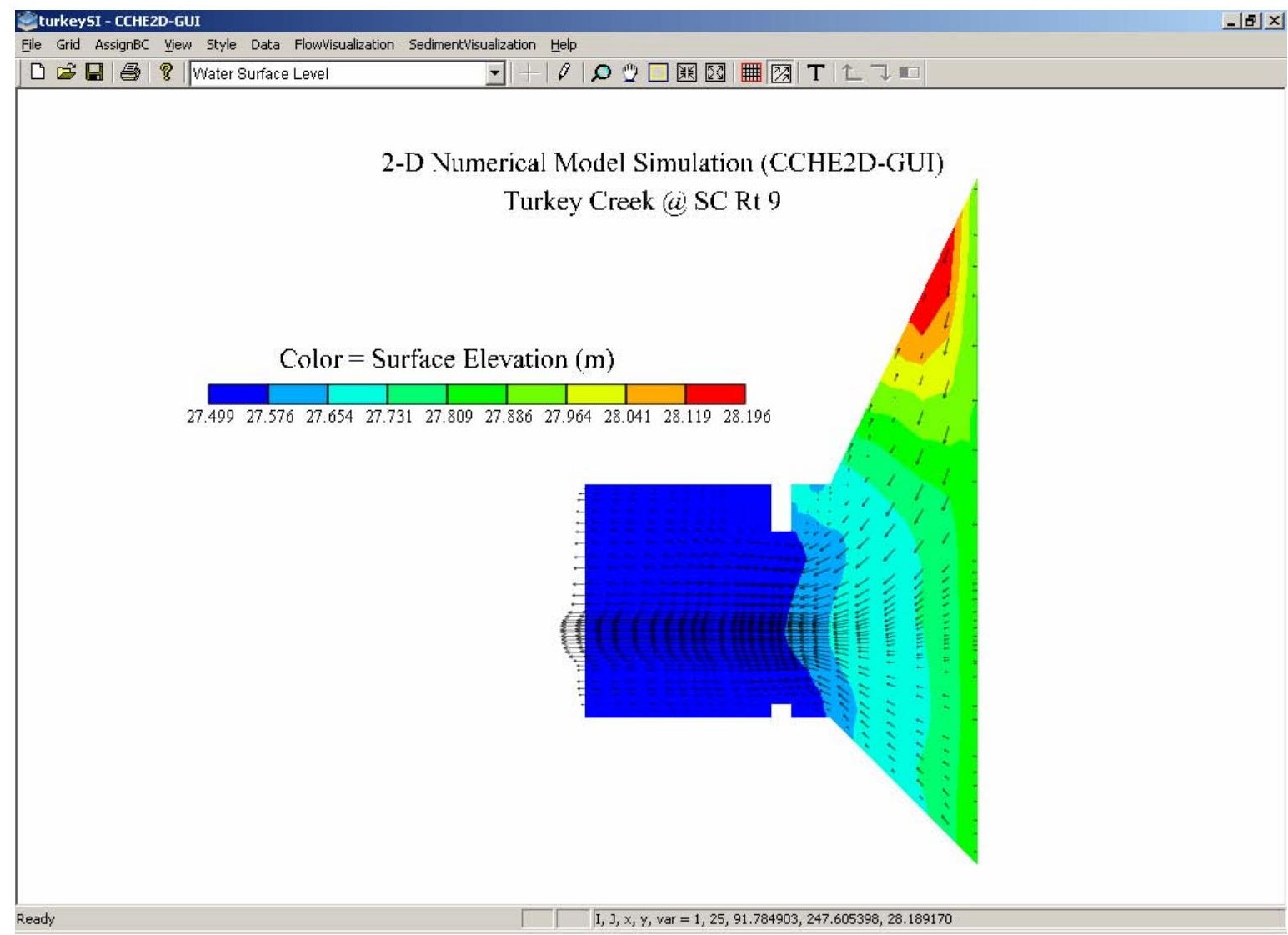

Figure 40. The Vector Plot from the Results after 1,000 second Simulation by CCHE2D-GUI (Zhang, 2005) 


\section{SELECTED REFERENCES}

Benedict, S.T., 2003, Clear-water abutment and contraction scour in the Coastal Plain and Piedmont Provinces of South Carolina, 1996-99: U.S. Geological Survey, Water-Resources Investigations Report 03-4064, 137 p.

Benedict, S.T., Deshpande, N., Aziz, N.M., and Conrads, P.A., 2006, Trends of abutment-scour prediction equations applied to 144 field sites in South Carolina: U.S. Geological Survey, Open-File Report 03-295, 150 p.

Jia, Y.F. and Wang, Sam S.Y., 2001, CCHE2D: Two-dimensional hydrodynamic and sediment transport model for unsteady open channel flow over loose bed: National Center for Computational Hydroscience and Engineering Technical Report. NCCHE-TR-2001-01, Aug. 2001, 89 p.

Maryland State Highway Administration, 2006, Maryland State Highway Administration abutment scour program (ABSCOUR), Version 7, build 1.03, compiled January 6, 2006

Maryland State Highway Administration, 2005, Evaluating scour at bridges: Manual for hydrologic and hydraulic design, v. 2, chapter

Shearman, J.O., 1990, User's manual for WSPRO-A computer model for water-surface profile computations: Federal Highway Administration, Report no. FHWA-IP-89027, $175 \mathrm{p}$.

Zhang, Yaoxin., 2005, CCHE2D-GUI: Graphical user interface for the CCHE2D model user's manual - version 2.2: National Center for Computational Hydroscience and Engineering Technical Report No. NCCHE-TR-2005-03, 83 p. 
Prepared by:

USGS Enterprise Publishing Network

Publishing Service Center (PSC) 5

3916 Sunset Ridge Road

Raleigh, NC 27607

For additional information regarding this publication, contact:

Director

South Carolina Water Science Center

720 Gracern Road, Suite 129

Columbia, SC 29210

phone: 1-803-750-6100

email: dc_sc@usgs.gov

Or visit the South Carolina Water Science Center website at: http://sc.water.usgs.gov 
$\vec{E}$

空

$\frac{10}{20}$

ק्ञ

三

造

(7)

을

$\prod_{0}^{\infty}$

要

क

ग्ञ

윽

產

త્ఝ

8 Printed on recycled paper 
$\vec{E}$

空

$\frac{10}{20}$

ק्ञ

三

造

(7)

을

$\prod_{0}^{\infty}$

要

क

ग्ञ

윽

產

త્ఝ

8 Printed on recycled paper 
$\vec{E}$

空

$\frac{10}{20}$

ק्ञ

三

造

(7)

을

$\prod_{0}^{\infty}$

要

क

ग्ञ

윽

產

త્ఝ

8 Printed on recycled paper 
$\vec{E}$

空

$\frac{10}{20}$

ק्ञ

三

造

(7)

을

$\prod_{0}^{\infty}$

要

क

ग्ञ

윽

產

త્ఝ

8 Printed on recycled paper 
$\vec{E}$

空

$\frac{10}{20}$

ק्ञ

三

造

(7)

을

$\prod_{0}^{\infty}$

要

क

ग्ञ

윽

產

త્ఝ

8 Printed on recycled paper 
$\vec{E}$

空

$\frac{10}{20}$

ק्ञ

三

造

(7)

을

$\prod_{0}^{\infty}$

要

क

ग्ञ

윽

產

త્ఝ

8 Printed on recycled paper 
$\vec{E}$

空

$\frac{10}{20}$

ק्ञ

三

造

(7)

을

$\prod_{0}^{\infty}$

要

क

ग्ञ

윽

產

త્ఝ

8 Printed on recycled paper 
$\vec{E}$

空

$\frac{10}{20}$

ק्ञ

三

造

(7)

을

$\prod_{0}^{\infty}$

要

क

ग्ञ

윽

產

త્ఝ

8 Printed on recycled paper 
$\vec{E}$

空

$\frac{10}{20}$

ק्ञ

三

造

(7)

을

$\prod_{0}^{\infty}$

要

क

ग्ञ

윽

產

త્ఝ

8 Printed on recycled paper 
$\vec{E}$

空

$\frac{10}{20}$

ק्ञ

三

造

(7)

을

$\prod_{0}^{\infty}$

要

क

ग्ञ

윽

產

త્ఝ

8 Printed on recycled paper 
$\vec{E}$

空

$\frac{10}{20}$

ק्ञ

三

造

(7)

을

$\prod_{0}^{\infty}$

要

क

ग्ञ

윽

產

త્ఝ

8 Printed on recycled paper 
$\vec{E}$

空

$\frac{10}{20}$

ק्ञ

三

造

(7)

을

$\prod_{0}^{\infty}$

要

क

ग्ञ

윽

產

త્ఝ

8 Printed on recycled paper 
$\vec{E}$

空

$\frac{10}{20}$

ק्ञ

三

造

(7)

을

$\prod_{0}^{\infty}$

要

क

ग्ञ

윽

產

త્ఝ

8 Printed on recycled paper 
$\vec{E}$

空

$\frac{10}{20}$

ק्ञ

三

造

(7)

을

$\prod_{0}^{\infty}$

要

क

ग्ञ

윽

產

త્ఝ

8 Printed on recycled paper 
$\vec{E}$

空

$\frac{10}{20}$

ק्ञ

三

造

(7)

을

$\prod_{0}^{\infty}$

要

क

ग्ञ

윽

產

త્ఝ

8 Printed on recycled paper 
$\vec{E}$

空

$\frac{10}{20}$

ק्ञ

三

造

(7)

을

$\prod_{0}^{\infty}$

要

क

ग्ञ

윽

產

త્ఝ

8 Printed on recycled paper 
$\vec{E}$

空

$\frac{10}{20}$

ק्ञ

三

造

(7)

을

$\prod_{0}^{\infty}$

要

क

ग्ञ

윽

產

త્ఝ

8 Printed on recycled paper 
$\vec{E}$

空

$\frac{10}{20}$

ק्ञ

三

造

(7)

을

$\prod_{0}^{\infty}$

要

क

ग्ञ

윽

產

త્ఝ

8 Printed on recycled paper 
$\vec{E}$

空

$\frac{10}{20}$

ק्ञ

三

造

(7)

을

$\prod_{0}^{\infty}$

要

क

ग्ञ

윽

產

త્ఝ

8 Printed on recycled paper 
$\vec{E}$

空

$\frac{10}{20}$

ק्ञ

三

造

(7)

을

$\prod_{0}^{\infty}$

要

क

ग्ञ

윽

產

త્ఝ

8 Printed on recycled paper 